\title{
The effects of halides on the
} performance of coal gas-fueled molten carbonate fuel cells: Final report, October 1986-October 1987

\author{
Magee, T.P.; Kunz, H.R.; Krasij, M.; Cote, H.A.
}

Oct 1987

International Fuel Cells Corp., South Windsor, CT (USA)

Reproduced and Distributed by:

U.S. DEPARTMENT OF ENERGY

Office of Scientific and Technical Information

P.O. Box 62

Oak Ridge, TN 37831 


\section{DISCLAIMER}

This report was prepared as an account of work sponsored by an agency of the United States Government. Neither the United States Government nor any agency Thereof, nor any of their employees, makes any warranty, express or implied, or assumes any legal liability or responsibility for the accuracy, completeness, or usefulness of any information, apparatus, product, or process disclosed, or represents that its use would not infringe privately owned rights. Reference herein to any specific commercial product, process, or service by trade name, trademark, manufacturer, or otherwise does not necessarily constitute or imply its endorsement, recommendation, or favoring by the United States Government or any agency thereof. The views and opinions of authors expressed herein do not necessarily state or reflect those of the United States Government or any agency thereof. 


\section{DISCLAIMER}

Portions of this document may be illegible in electronic image products. Images are produced from the best available original document. 


\section{DISCLAIMER}

This report was prepared as an account of work sponsored by an agency of the United States Government. Neither the United States Government nor any agency thereof, nor any of their employees, makes any warranty, express or implied, or assumes any legal liability or responsibility for the accuracy, completeness, or usefulness of any information, apparatus, product, or process disclosed, or represents that its use would not infringe privately owned rights Reference herein to any spe cific commercial product, process, or service by trade name, trademark, manufacturer, or otherwise does not necessarily constitute or imply its endorsement, recommendation, or favoring by the United States Government or any agency thereof. The views and opinions of authors expressed herein do not necessarily state or reflect those of the United States Government or any agency thereof.

This report has been reproduced directly from the best available copy.

Available from the National Technical Information Service, U. S. Department of Commerce, Springfield, Virginia 22161.

Price: Printed Copy A10

Microfiche A01

Codes are used for pricing all publications. The code is determined by the number of pages in the publication. Information pertaining to the pricing codes can be found in the current issues of the following publications, which are generally available in most libraries: Energy Research Ahstracts (ERA); Government Reports Announcements and Index (GRA and I); Scientific and Technical Abstract Reports (STAR); and publication NTIS-PR-360 available from NTIS at the above address. 


\title{
The Effects of Halides on the Performance of Coal Gas-Fueled Molten Carbonate Fuel Cells
}

\author{
Final Report, October 1986-October 1987
}

\author{
T.P. Magee \\ H.R. Kunz \\ M. Krasij \\ - H.A. Cote
}

Work Performed Under Contract No.: DE-AC21-86MC23136

\author{
For \\ U.S. Department of Energy \\ Office of Fossil Energy \\ Morgantown Energy Technology Center \\ P.O. Box 880 \\ Morgantown, West Virginia 26507-0880 \\ By \\ International Fuel Cells Corporation \\ 195 Grovernor's Highway \\ P.O. Box 739 \\ South Windsor, Connecticut 06074
}


ABSTRACT

This report presents the results of a program to determine the probable tolerable limits of hydrogen chloride and hydrogen fluoride present in the fuel and oxidant streams of molten carbonate fuel cells that are operating on gasified coal. A literature survey and thermodynamic analyses were performed to determine the likely effects of halides on cell performance and materials. Based on the results of these studies, accelerated corrosion experiments and electrode half-cell performance tests were conducted using electrolyte which contained chloride and fluoride. These data and the results of previous in-cell tests were used to develop a computer model for predicting the performance decay due to these halides. The tolerable limits were found to be low (less than $1 \mathrm{ppm}$ ) and depend on the power plant system configuration, the operating conditions of the fuel cell stack, the cell design and initial electrolyte inventory, and the ability of the cell to scrub low levels of halide from the reactant streams. The primary decay modes were conversion of the electrolyte from pure carbonate to a carbonate-halide mixture and accelerated elertrolyte evaporation. 


\section{ACKNOWLEDGEMENTS}

This report represents the results of a project sponsored by the Department of Energy (DOE), Morgantown Energy Technology Center (METC), with International Fuel Cells.(IFC)... : The guidance and assistance provided by the DOE Project Manager, Suresh Jain, are greatly appreciated. The authors acknowledge the effort of W.M. Vogel in the thermodynamic calculations. 


\section{THIS PAGE}

\section{WAS INTENTIONALILY \\ $\therefore \quad L E F T$ BLANK}




\section{TABLE OF CONTENTS}

SECTION

EXECUTIVE SUMMARY

Task 1 - Literature Survey and Analysis

Task 2 - Test Plan

Task 3 - Out-of-Cell Investigation

Corrosion Tests

Half-Cell Tests

Task 4 - In-Cell Investigation

Task 5 - Post-Test Analysis

Task 6 - Model Development

CONCLUSIONS \& RECOMMEÑDATIONS

REFERENCES

APPENDIX A - Electrolyte Equilibrium Constants

APPENDIX B - Task 2 - Test Plan

\section{PAGE}

1

$1-1$

$2-1$

$3-1$

$3-1$

$3-16$

$4-1$

$5-1$

$6-1$

$7-1$

$R-1$

$A-1$

$B-1$ 


\section{List of Figures}

\section{Figure}

Page

1-1 Alkali-Metal Chloride Vapor Pressure as a Function of Chloride in Melt

1-2 Alkali-Metal Fluoride Vapor Pressure as a Function of Fluoride in Melt

1-3 Steady State Halide Balance

1-4 Nickel Electrode Degradation by $\mathrm{HCl}$

$3=1$ Half-Cell Schematic

3-2 Cathoie Half-Ćll Configuration

3-3 Anode Half-Cell Configuration

3-4 Experimental Half-Cell Setup 3-7

3-5 Concentration Difference Test Results vs. Nernst 3-9 Equation

3-6 Half-Cell Cathode Test \#3

3-7 Effect of Halide on Cathode Half-Cell 3-13

3-8 Half-Cell Cathode Test \#6 3=15

1-9 Cathode Test \#6 slow Sweep Performance Curve \# 1 . 3-17

3-10 Cathode Test \#6 Slow Sweep Performance Curve \#2 3-18

3-11 Cathode Test \#6 Fast Sweep Performance Gurve \#1 3-19

3-12 Cathode Test \#6 Fast Sweep Performance Curve \#2 3-20

3-13 Half-Cell Cathode Tes't \#8 3-21

3-14 Cathode Test \#8 Eact Ewcep Fes [urmance lurve \#1 3-22

3-15 Calliude Test \#8 Fast Sweep Performance Curve \#2 3-23

3-16 Half-Cel1 Cathode Test \#9 3-25

3-17 Cathode Test \#9 Fast Sweep Performance Curve \#l With 3-26 $660 \mathrm{llg}$ of Electrolyte in the Cell 
List of Figures

3-18 Cathode Test \#9 Fast Sweep Performance Curve \#2 With 3-27 $660 \mathrm{mg}$ of Electrolyte in the Cell

3-19 Cathode Test \#9 Fast Sweep Performance Curve \#3 with 3-28 $660 \mathrm{mg}$ of Electrolyte in the Cell

3-20 Cathode Test \#9 Slow Sweep Performance Curve 3-29

3-21 Cathode Test \#9 Performance Curve With $643 \mathrm{mg}$ of 3-30 Electrolyte in the Cell

3-22 Cathode Test \#9 Performance Curve \#1 With $629 \mathrm{mg}$ of 3-31 Electrolyte in the Cell

3-23 Cathode Test \#9 Performance Curve \#2 With $629 \mathrm{mg}$ of 3-32 Electrolyte in the Cell

3-24 Cathode Test \#9 Performance Curve \#3 With $629 \mathrm{mg}$ of 3-33 Electrolyte in the Cell

3-25. Cathode Test \#9 Potential Sweep after Current Step 3-34

3-26 Half-Cell Anode Test \#1 3-36

3-27 Anode Overpotential vs. Percent Fill 3-37

3-28. Half-Cell Anode Test \#2 3-38

3-29 Anode Test \#2 Performance Curve With $655 \mathrm{mg}$ of 3-39 Electrolyte in the Cell

3-30 Anode Test \#2 Performance Curve With $609 \mathrm{mg}$ of 3-40 Electrolyte in the ell

3-31 Half-Cell Anode Test \#3 3-41

3-32 Anode Test \#3 Performance Curve \#1 3-42

3-33 Anode Test \#3 Performance Curve \#2 3-43

3-34 Anode Test \#3 performance Curve \#3 3-44

3-35 Anode Test \#3 Potential Sweep After Current Step 3-45

3-36 Schematic of Retort Test 3-48

3-37 Photomicrograph of the Pre-Test Alloys 3-50

(oxalic/electrolytic etch) 
3-38 Photomicrographs of AISI 316 Alloy Tested for 1000 Hours in a Molten Carbonate Environment at $760^{\circ} \mathrm{C}$ (oxalic/electrolytic etch)

3-39 Photomicrographs of AISI 310 Alloy Tested for 1000 Hours in a Molten Carbonate Environment at $760^{\circ} \mathrm{C}$ (oxalic/electrolytic etch)

3-40 Photomicrographs of Incoloy 825 Alloy Tested for 1000 Hours in a Molten Carbonate Environment at $760^{\circ} \mathrm{C}$ (oxalic/electrolytic etch)

3-41 Schematic of the Metalloqraphic Technique Isod for the Corrosion Tests

3-42 Backscatter Elertron Image (BEI) and Elemental X-Ray 3-57 Maps of the AISI 316 Control Specimen Tested for 1000 Hours at $760^{\circ} \mathrm{C}$ in a Molten Carbonate Environment Free of Halides

3-43 Backscatter Electron Image (BEI) and Elemental X-Ray Maps of the AISI 316 Specimen Tested for 1000 Hours at $760^{\circ} \mathrm{C}$ in a Molten Carbonate Environment Containing $10 \mathrm{ppm} \mathrm{Cl}_{1}$ in the Oxidant Gas

3-44 Backscatter Electron Image (BEI) and Elemental X-Ray Maps of the AISI 316 Specimen Tested for 1000 Hours at $1400^{\circ} \mathrm{F}$ in a Molten Carbonate Environment Containing $10 \mathrm{ppm} F$ in the oxidant Gas

3-45 Backscatter Electron Image (BET) and Elemental X-Ray

Maps of the AISI 310 Control Specimen Tested for 1000 Hours at $760^{\circ} \mathrm{C}$ in a Molten Carbonate Environment Free of Halides

3-46 Backscatter Electron Image (BEI) and Elemental X-Ray Maps of the AISI 310 Specimen Tested for 1000 Hours at $760^{\circ} \mathrm{C}$ in a Molten Carbonate Environment Contain$10 \mathrm{ppm} \mathrm{Cl}$ in the Oxidant Gas

3-47 Backscatter Electron Image (BEI) and Elemental X-Ray Maps of the AISI 310 Specimen Tested for 1000 Hours at $1400^{\circ} \mathrm{F}$ in a Moleen Carbonate Environment Conlainlng $10 \mathrm{ppm} F$ in the Oxidant Gas

3-48 Backscatter Electrop Image (BEI) and Elemental X-Ray
Maps of the Incoloy 825 Control Specimen Tested for 1000 Hours at $760^{\circ} \mathrm{C}$ in a Molten Carbonate Environiment Free of Halides 
List of Figures

3-49 Backscatter Electrop Image (BEI) and Elemental X-Ray
Maps of the Incoloy Specimen Tested for 1000 Hours
at $760^{\circ} \mathrm{C}$ in a Molten Carbonate Environment Containing
$10 \mathrm{ppm} \mathrm{Cl}$ in the Oxidant Gas

3-50 Backscatter Electrop Image (BEI) and Elemental X-Ray 3-67 Maps of the Incoloy 825 Specimen Tested for 1000 Hours at $1400^{\circ} \mathrm{F}$ in a Molten Carbonate Environment Containing $10 \mathrm{ppm} F$ in the Oxidant Gas

5-1 Effect of Fluoride on NiO Expansion. 5-5

6-1 Potential Difference Due to Difference in 6-5 Electrolyte Composition

6-2 Calculated Vapor Pressures of Halides 6-7

6-3 Performance Vs. Electrolyte Fill for Anode 6-16.

6-4 Summary of Cathode Performance on Halide-Free 6-18 Electrolyte

6-5 Comparison of Preliminary Model With Existing Cell 6-23 Data for Early Time Periods With HCl in Fuel

7-1 Predicted Performance Decay in 40,000 Hours Due to 7-3 Halides

7-2 Effect of Operating Pressure on Performance Loss 7-10

A-1 Equilibrium Constant for Reaction A-1 A-3

A-2 Equilibrium Constant for Reaction A-2 A-4

A-3 Equilibrium Constant for Reaction A-3 A-6

A-4 Equilibrium Constant for Reaction A-4 A-7

A-5 Equilibrium Constant for Reaction $A-5$. A-8

A-6 Equilibrium Constant for Reaction A-6 A-9

A-7 Equilibrium Constant for Reaction A-7 A-11

A-8 Equilibrium Constant for Reaction A-8 A-12

A-9 Equilibrium Constant for Reaction A-9 A-13 
List of Figures

A-10 Equilibrium Constant for Reaction A-10

A -14

A-11 Equilibrium Constant for Reaction A-11

A- 15

A-12 Equilibrium Constant for Reaction A-12

A-16

B-l Half-Cell Apparatus

$\mathrm{B}-4$ 
1-1 Steady State Halide Concentrations in Electrolyte 1-13

3-1 Half-Cel1 Components 3-5

3-2 Half-Cell Test Summary - $\quad 3-10$

3-3 Summary of the 1000 Hour Metallographic and Weight 3-55 Change Data

4-1 Experimental Conditions for Previous Chloride Tests 4-2 (Cell No. 319)

4-2 Experimental Data for Test With $10 \mathrm{ppm} \mathrm{HCl}$ in Fuel 4-3

4-3 Experimental Data for Test With $60 \mathrm{ppm} \mathrm{HCl}$ in Fuel 4-4

5-1 Half-Cell Post-Test Observations Summary 5-4

5-2 Half-Cell Post-Test Observations Summary 5-10

6-1 Anode Polarization Values 6-11

6-2 Method of Calculating Initial Mass of Electrolyte 6-1.3 in the Cell per Unit Area

6-3 Experimental Conditions for Previous Chloride Tests 6-22 (Cell No. 319)

7-1 Etack Operating Conditions 7-2

7-2 Component Polarizations 7-5

7-3 Component Polarizations for 10 ppm In-Cell Test 7-6

7-4 Component Polarizations for $60 \mathrm{ppm}$ In-Cell Test 7-7 


\section{EXECUTIVE SUMMARY}

The Department of Energy (DOE), Morgantown Energy Technology Center (METC), is sponsoring several programs aimed at the development of the coal gasifier/molten carbonate fuel cell power plant. Several of these programs are aimed at defining and improving the tolerance of molten carbonate fuel cells (MCFC) to impurities present in coal-derived gases. Other programs have as their objective the development of hot gas cleanup systems for the removal of impurities to enable the mating of the coal gasifier and molten carbonate fuel cell. This report describes the results of a study conducted at International Fuel Cells (IFC) on the effects of halides present in coal-derived gases on the performance of molten carbonate fuel cells.

The program consisted of several tasks. First, a literature survey and thermodynamic analyses were performed to determine the anticipated effects of halides. These results were used to formulate a test plan. The tests included laboratory out-of-cell measurement of the performance of anodes and cathodes with halides present in the electrolyte and corrosion measurements on materials of construction. These data and previous data from in-cell tests were used to develop a model for the prediction of the effects of halides on cell performance. The following paragraphs describe the results obtained in the various tasks.

Task 1 - Literature Survey and Analysis

Halides present in reactant gases are expected to affect molten carbonate fuel cells in several ways. Effects observed in short-term tests performed by the General Electric Company and the United Technologies Corporation include hardware corrosion, presumed anode poisoning, electrolyte con- 
tamination, enhanced electrolyte loss, changes in cathode morphology and chlorination of the $\mathrm{LiAlO}_{2}$ matrix.

Thermodynamic calculations show that halides, in the form of $\mathrm{HCl}$ and $\mathrm{HF}$, in the presence of molten lithium and potassium carbonates, are converted almost completely to carbon dioxide, water and lithium and potassium halides. This means that molten carbonate cells are effective scrubbers in removing HCl and HE from thc reactant sliedlls. Lhiorides are expected to increase the rate of electrolyte loss in the cell due to the high vapor pressures of $\mathrm{LiCl}$ and $\mathrm{KCl}$ and perhaps pose an electrolyte contamination problem at ppm levels in the gas phase.

Fluorides are expected to cause less of an electrolyte lose problem due to lower KF and LiF vapor pressures. However, the slower rate of fluoride evaporation will convert the electrolyte more readily. The inlet concentration of both halides will have to be maintained at a level low enough so that loss of electrolyte and conversion of the electrolyte will not reduce cell performance excessively.

Nickel anode corrosion due to $\mathrm{HCl}$ in the fuel was not seen in any prior in-cell test. Thermodynamic calculations confirm these observations and show that anode corrosion will not be a concern. Anodes were shown to be able to tolerate up to 100 ppmv chlorides, at least in the short term.

Cathode hardware corrosion was considerable even at 10 ppmv HCl. Changes in cathode morphology and a loss of adherence of particles were seen after only six days of 100 ppmv HCl. Thermodynamic confirmation of these observed results was not possible due to the lack of appropriate data.

The $\mathrm{LiAlO}_{2}$ matrix from a cell operated with $\mathrm{HCl}$ in the reactants was found to contain $\mathrm{HCl}$, LiCl, and/or LiAlOCl${ }_{2}$. These observations could also not be confirmed thermodynamically because of the lack of appropriate 
data, but calculations did show that the conversion of the matrix to $\mathrm{Li}_{3} \mathrm{AlF}_{6}$ is possible.

Post-test analyses of cells that operated with HCl in the oxidant and results of the literature survey indicate that halides in a molten carbonate fuel cell will accelerate the corrosion rate of structural alloys such as AISI 316 stainless steel used in separator plates.

Task 2 - Test Plan

The test plan was based on the understanding of the effects of chlorides and fluorides obtained in the literature survey and thermodynamic analyses.

Hydrogen chloride in a molten carbonate reactant gas is anticipated to react quantitatively with the electrolyte to form chlorides. These chlorides will accelerate the corrosion of cathode-șide components and lead to conversion of the electrolyte until the rate of chloride loss balances the rate of input. The vapor pressure of the chlorides is expected to be high enough for these rates to be balanced with a relatively small conversion of the electrolyte from carbonate to chloride. The loss of electrolyte will be greatly accelerated due to the chloride.

Hydrogen fluoride in the reactant gases is anticipated to have somewhat different effects. The effect on corrosion of cathode-side components is unknown. Since the vapor pressures of lithium and potassium fluoride are much less than those of the chlorides, they will not evaporate from the electrolyte as rapidly, and more conversion of the electrolyte may take place. Compared to chlorides, fluorides will affect pertormance more through electrolyte conversion than through electrolyte loss.

Because of these anticipated effects, out-of-cell tests were planned for Task 3 to determine the effects of chloride and fluoride in the electrolyte 
on the corrosion of cathode-side components and to determine the short-term effects of halides on the performance of half-cell tests of both anode and cathode-side components.

Task 3 - Out-of-Cell Investigation

Experiments planned in Task 2 were implemented to determine the effects of chloride and fluoride on the performance of cathodes and on the corrosion of materials of construction. In order to determine the effect of halide in the electrolyte on electrode open circuit potential, a series of open circuit voltage measurements were made between electrodes in halideEree and halide-containing electrolytes. For both chloride and fluoride, the open clrcuit voltages increased due to the presence of halides, as would be expected, accounting for the reduced carbonate ion activity in the Nernst equation. These data were needed to predict the concentration polarization present in the thin layer of halide-containing electrolyte that is expected to develop in the anode when halide enters the cell through the fuel or oxidant.

Three anode and nine cathode half-cell performance tests were run in which electrolyte content was varied. The content was varied in each test because electrolyte loss is considered to be a major decay mode which is accelerated in the presence of halides. One anode and six cathode teṣts were performed using 72 mole percent $\mathrm{Li}_{2} \mathrm{CO}_{3}$ and 28 mole percent $\mathrm{K}_{2} \mathrm{CO}_{3}$ electrolyte containing no halide. This electrolyte composition was selected because it is the electrolyte composition used in present IFC single cells and stacks. The other two anode tests and three cathode tests were performed using the same electrolyte having various halidc contents: 23 anion percent chloride and 23 anion percent fluoride in the anode elecLivlyle, and 3.1 anion percent chloride, 23 anion percent chloride and 23 aniun percent fluoride in the cathode electrolyte.

Initial tests on halide-free electrolyte indicated that the data were not reproducible enough to accurately determine the effects of halides. Modi- 
fications incorporated into the half-cell improved reproducibility.

Performance results from tests having halide in the electrolyte clearly showed that chloride is detrimental to the cathode performance and the greater the concentration of chloride, the greater the effect. Fluoride, however, had little effect on the cathode. Anodes were not affected by halide in the electrolyte. Diagnostic tests performed in half cells indicated the presence of halide ion concentration gradients which resulted in concentration polarizations in agreement with the results measured earlier in the open circuit tests.

Visual observations were made on the half-cell test components after testing was completed. The thicknesses of components and the electronic resistivities of the electrodes were measured.

The cathode side stainless steel components were found to be significantly corroded by chloride, but not by fluoride. Fluoride, however, caused the nickel-oxide cathode components to swell more than usual. Halides appeared to lower post-test electrolyte chromate which comes from the oxidation. of chromium in the stainless steel. The surface of the nickel-oxide components was softened.

Corrosion testing was performed on three structural materials (AISI 310 stainless steel, AISI 316 stainless steel, and Incoloy $825^{(B)}$ in the cathode environment using halide-free electrolyte and electrolyte containing 3.1 anion percent chloride or fluoride. Results of these tests indicate that the presence of these halides accelerates the corrosion rate of all three alloys. In a halide-free and chloride-containing environment, the AISI 310 alloy was the most resistant of the three. However, in a fluoride-containing molten carbonate environment, the resistance to corrosion of AISI 310 alloy was comparable to that of AISI 316 and somewhat lower than that of Incoloy 825 . 
Metallographic and weight change data suggest that the halides accelerate the corrosion of the alloys by detrimentally affecting the adherence of the protective scales. This is evidenced by more oxide spalling in samples tested in the halide-containing environments than in the control samples.

SEM/Microprobe analyses showed that the oxide scales formed on the three alloys were similar in composition. The resistance of the alloys to corrosion appeared to be related to the uniformity, continuity, and compactness of the chromium-rich oxide protective layer. Breakdown of this layer resulted in increased corrosion. In the presence of fluoride, the corrosive attack appeared to be more intergranular in nature for all three alloys. This is evidenced by the appearance of a chromium-rich oxide phase in the outermost grain boundaries of the base metal and by chromium depletion of the grain boundaries.

Task 4 - In-Cell Investigation

The in-cell test data used in this contract were obtained previously under Contract No. DE-ACO1-79ET15440 between the Department of Energy and International Fuel Cells. Those experiments consisted of ambient pressure endurance tests with $10 \mathrm{ppm}$ and $60 \mathrm{ppm} \mathrm{HCl}$ added to the fuel gas. Both tests were run until a large decay in performance was experienced, about $40 \mathrm{mv}$ in 522 hours for the $10 \mathrm{ppm}$ test and $80 \mathrm{mv}$ in 10 hours for the 60 ppm test.

Task 5 - Post-Test Analysis

After the completion of the half-cell tests, post-test observations were made on each component. Observations included thickness and resistivity measurements and visual inspection of each part. The most significant effect found in the half-cell post-test analysis was the corrosion and 
spalling of the cathode side stainless steel in the presence of chloride. A similar effect was observed to be not as pronounced in the presence of fluoride.

A potentially significant effect was observed in the case of nickel oxide in the presence of fluoride. In this case the nickel oxide swelled in thickness twice as much as in any other test, even more than the nickel oxide in the presence of chloride." The fluoride may have affected the oxidation and lithiation of the nickel, but the fluoride itself may have entered the lattice structure of the NiO. Under external component compression, this could lead to a denser cathode and a change in electrolyte distribution throughout a cell.

Other important observed effects included a possible interaction between the chromium in the stainless steel and halides, and softening of the, nickel oxide components.

Task 6 - Develop a Model to Predict Effect of Halides on MCFC

Using the results of the literature survey, thermodynamic analyses and out-of-cell tests, the mechanisms by which halides cause decay were postulated. A computer model was developed including the major decay modes of conversion of the electrolyte from carbonate to halide and electrolyte loss due to increased vapor pressures. This model was compared to the results of the in-cell tests and found to agree with that data.

The model indicates that halide present in the electrolyte tends to be concentrated in the anode, resulting in a different electrolyte composition between the electrodes. This composition difference results in a concentration polarization and liquid-junction potential and a performance loss. The higher volatility of the halides increases the rate of electrolyte 10ss. Because the electrolyte is shared between the anode, cathode, 
and matrix, electrolyte loss results in some loss from all of these components. The relative amounts depend on the component pore size distributions. Most of the polarization increase due to electrolyte loss for the present cell design was found to be due to the anode.

The tolerance limit of the stack to halides was found to depend on the operating conditions of the stack and the system which incorporates the stack. For example, with halide present in the fuel gas, the halide flow in the fuel vent will increase with time. If that fuel is completely burned to provide carbon dioxide for the oxidant, the halide in the fuel exhaust may reenter the cell in the oxidant inlet. If the halide is scrubbed from the oxidant and transported to the anode, the halide may be trapped within the stack. The tolerance level of such a system would be different from that in which part of the fuel effluent is recirculated.

For a stack operating at $172 \mathrm{ma} / \mathrm{cm}^{2}$ and $10 \mathrm{~atm}$ pressure using a fuel gas obtalned from an $\mathrm{O}_{2}$-blown Texaco gasifier at 85 percent $\mathrm{H}_{2}+\mathrm{CO}$ utilization and an oxidant dilute in $\mathrm{CO}_{2}$ (to provide long cathode 1 ife) at 37 percent $\mathrm{CO}_{2}$ utilization, the tolerance levels to both $\mathrm{HCl}$ and $\mathrm{HF}$ are about 0.1 ppm based on a performance loss of $20 \mathrm{mv}$ in 40,000 hours. This result applies to a system in which the oxidant is free of halides. This tolerance level pertains to the present cell parkage design and initial nlortrolyte inventory. Tolerance can be increased by increasing cell tolerance to electrolyte loss, by increasing the initial electrolye inventory, and by adding electrolyte during the power plant life.

This low a tolerance level to halide casts doubts on the assumption made in the model that complete scrubbing of $\mathrm{HCl}$ and $\mathrm{HF}$ occurs within the stacks and that complete saturation with the alkali metal. halides occurs at the fuel exit. At this low halide content, the stack may not be an efficient scrubber and saturator. 
Increase in contact resistances between components in the cell due to accelerated corrosion was not included in the model because of the results of the corrosion tests and the low tolerance level in the absence of this loss.

Task 7 - Management and Documentation

All management functions -were performed including contract administration, technical control, schedule control, cost control, subcontract management, documentation and communications. 
TASK 1 - LITERATURE SURVEY AND ANALYSIS

\section{LITERATURE SURVEY}

A literature survey was conducted to obtain any pertinent information on the effects of chloride and fluoride on the performance of molten carbonate fuel cells. The subjects surveyed consisted of experimental tests in which halides had been introduced into cells, properties of mixtures of lithium and potassium carbonate with chloride and fluoride, and the effects of chlorides and fluorides on the corrosion of molten carbonate cell materials. Thermodynamic data obtained in this survey were used to make calculations to determine the modes of decay to be anticipated. These anticipated modes were then compared with observations from the cell tests in which chlorides were introduced.

\section{Observed Effects of Halides in Cells}

Chloride, in the form of $\mathrm{HCl}$, was found to be detrimental in short-term subscale molten carbonate fuel cells in two independent studies. General Electric studied the effects of $10 \mathrm{ppmv} \mathrm{HCl}$ and $100 \mathrm{ppmv} \mathrm{HCl}$ in the fuel and in the oxidant [1]. One cell ran for 24 days with 10 ppmv $\mathrm{HCl}$ in the fuel, without any loss in performance necessarily attributable to the halide. A second cell, which ran with $100 \mathrm{ppmv} \mathrm{HCl}$ in the fuel for 60 days, suffered slight increases in anode polarization. However, this same cell when run with 100 ppmv $\mathrm{HCl}$ in the oxidant for 6 days showed a dramatic loss in cathode performance. A third cell ran for 26 days with 100 ppmv $\mathrm{HCl}$ in the fuel and $10 \mathrm{ppmv} \mathrm{HCl}$ in the oxidant. Anode and cathode performance started to deteriorate after about 12 days with $\mathrm{HCl}$ in the reactant gases.

UTC studied the effects of $\mathrm{HCl}$ in the fuel [2]. After 60 ppmv $\mathrm{HCl}$ was added to the fuel, the cell decayed $81 \mathrm{mV}$ at $160 \mathrm{ASF}$ in ten hours. Cell 
performance recovered quickly and completely after the introduction of halide-free fuel. Later, $10 \mathrm{ppmv} \mathrm{HCl}$ was introduced into the fuel causing an immediate loss of $12 \mathrm{mV}$ at 160 ASF followed by 21 days of slow decay. The section describing Task 4 discusses these data in greater detail.

Both GE and UTC found evidence of anode poisoning by large amounts of $\mathrm{HCl}$ (60 ppmv or greater). HCl, at low levels of 0.5 to $2 \mathrm{ppm}$, is known to poison catalysts for the methanation.reaction, but poisoning of the shift reaction or the electrochemical oxidation reaction has not been demonstrated in electrochemical cells [3]. Park and O'Brien expected the anode to dissolve by the reaction: $\mathrm{Ni}(\mathrm{s})+2 \mathrm{HCl}(\mathrm{g}) \rightarrow \mathrm{NiCl}_{2}(\mathrm{~s})+\mathrm{H}_{2}(\mathrm{~g})[4]$, but neither the GE or the UTC study noticed any corrosion of the nickel anode or of the wet seal. GE, however, did find a buildup of corrosion products from the stainless steel hardware in the anode exit gas channel.

The cathode is expected to dissolve by the reaction: $\mathrm{NiO}(\mathrm{s})+2 \mathrm{HCl}(\mathrm{g}) \rightarrow$ $\mathrm{NiCl}_{2}(\mathrm{~s})+\mathrm{H}_{2} \mathrm{O}(\mathrm{g})$ [4]. The GE study found that with. 100 ppmv $\mathrm{HC}$ ? in oxidant that the Nio cathode showed signs of changes in morphology and a loss of adherence of particles. The cathode hardware was severely corroded and the stainless steel current collector corroded extensively near the inlet side of the cathode. A buildup of corrosion products developed in the cathode exit port, causing the third GE test cell to fail.

Halides react with the electrolyte by: $2 \mathrm{HX}(\mathrm{g})+\mathrm{M}_{2} \mathrm{CO}_{3}(1)-2 \mathrm{MX}(1)+$ $\mathrm{H}_{2} \mathrm{O}(\mathrm{g})+\mathrm{CO}_{2}(\mathrm{~g})$ where $\mathrm{X}$ is either $\mathrm{F}$ or $\mathrm{Cl}$ (or other halide) and $M$ is either Li or $\mathrm{K}$. The GE study, in an out-of-cell test, found that at $923 \mathrm{~K}$ with $100 \mathrm{ppmv} \mathrm{HCl}$ in the oxidant and fuel, the anode electrolyte tile contained $3.6 \mathrm{wt}$. percent chlorides after 30 hours and the cathode electrolyte tile contained 1.2 wt. percent chlorides after 58 hours. Electrolyte loss rates through evaporation are expected to increase because of alkali halides in the melt. The UTC test cell, which used considerably less electrolyte 
than any of the GE test cells, lost 62 percent of its original electrolyte after 62 days of testing. Kruglov et al. found that $\mathrm{Na}_{2} \mathrm{CO}_{3}$ and $\mathrm{K}_{2} \mathrm{CO}_{3}$ in the presence of $\mathrm{Nax}$ or $\mathrm{KX}$, respectively, where $\mathrm{X}$ is either $\mathrm{Cl}$ or $\mathrm{F}$, dissociated, giving off $\mathrm{CO}_{2}$ [5]. The degree of dissociation of $\mathrm{K}_{2} \mathrm{CO}_{3}$ at $973 \mathrm{~K}$ remained below 16 percent when $\mathrm{KX}$ content was below 60 mole percent. GE also conducted X-ray diffraction studies of the $\mathrm{LiAlO}_{2}$ matrix which revealed that chlorides were present in the form of $\mathrm{HCl}$ and $\mathrm{LiCl}$ and/or $\mathrm{LiAlOCl}_{2}$.

\section{Halide Properties}

Thermodynamic property data for most of the species involved in the reaction of halides with the electrolyte were found in JANAF Thermochemical Tables [6]. Other thermodynamic property data were found in Barin and Knacke [7]. Janz et al. has compiled vapor pressure data for $\mathrm{Li}_{2} \mathrm{CO}_{3}$, $\mathrm{K}_{2} \mathrm{CO}_{3}, \mathrm{LiCl}, \mathrm{KCl}, \mathrm{LiF}$, and $\mathrm{KF}$ in their pure states and has also compiled phase diagrams for $\mathrm{LiCl}-\mathrm{KCl}, \mathrm{LiF}-\mathrm{LiCl}, \mathrm{Li}_{2} \mathrm{CO}_{3}-\mathrm{K}_{2} \mathrm{CO}_{3}$ and others involving alkali metals and halides [20]. Janz, also gave references and some data for various physical, thermodynamic and electrochemical properties for numerous molten salts [35]. Janz also assisted in obtaining references through the Rensselaer Polytechnic Institute Molten Salt Data Base.

\section{Materials Corrosion}

A computer literature search was conducted to determine the effect of halides on the corrosion of stainless steels, nickel-base alloys, and pure nickel in a molten carbonate environment. Chemical Abstracts (1967-1986), the Metals Index (1966-1986), and the Engineering Index (1970-1986) were searched. No references dealing specifically with the subject of interest were found. A number of references were noted in which the effect of halides on metal corrosion in air at elevated temperatures, in ( $N a, K) \mathrm{No}_{3}$ melts, and in gas turbine hot corrosion environments were addressed. 
Since molten carbonate salt mixtures are used in the heat treating industry and in air clean-up systems for scrubbing sulfur oxides, it is improbable that no data were published on the interaction of structural alloys with carbonate/halide salt mixtures. It was deduced, therefore, that the bulk of the work in these areas was conducted before computer files were established. As a result, a manual search of literature published prior to 1966 was conducted. A report on the survey results obtained follows.

In molten salt mixtures of lithium, sodium, the potassium carbonates, austentic stainless steels and nickel-base alloys form three types of passivated oxide films: metal oxides, spinels, and alkali metal - metal oxides [8]. $\mathrm{Cr}_{2} \mathrm{O}_{3}$ is normally not found on metal surfaces exposed to the melt. In a study conducted by Grantham et al. [8], at a temperature range of $930-1290^{\circ} \mathrm{F}\left(499-699^{\circ} \mathrm{C}\right)$ it was determined that the metal oxides were predominantly iron and nickel oxide, the spinels were predominantly iron chromite, $\mathrm{FeCr}_{2} \mathrm{O}_{4}$, and lithium chromite, $\mathrm{LiCrO}_{2}$, was the major constituent of the alkali metal - metal oxide film. The metal oxide films were found to be more prevalent at lower temperatures and in longer duration tests. The spinel structure was the dominant film at $930^{\circ} \mathrm{F}\left(499^{\circ} \mathrm{C}\right)$ even after one year of exposure. A cubic, disordered $\mathrm{LiCrO}_{2}$ film as observed at lower temperatures and shorter times.

These investigators noted that the metal oxide film initially formed transforms into cubic $\mathrm{LiCrO}_{2}$ which in turn transforms into the hexagonal $\mathrm{LiCrO}_{2}$ film by the action of the melt. The protectiveness of the $\mathrm{LiCrO}_{2}$ film was attributed to the compactness and tenacity of this material. Of the three alkali metals in the melt, only lithium was small enough to get into the $\mathrm{LiCrO}_{2}$ octahedral interstice without distorting the lattice. It was suggested that $\mathrm{IiCrO}_{2}$ was formed from two precursors: the metal oxide film, containing lithium, and the cubic oxide alkali metal - metal oxide film. The corrosion process was believed to be diffusion controlled. 
In another study [9] conducted in a binary $\mathrm{Li}_{2} \mathrm{CO}_{3}-\mathrm{K}_{2} \mathrm{CO}_{3}$ fuel cell electrolyte at $1205^{\circ} \mathrm{F}\left(652^{\circ} \mathrm{C}\right), \mathrm{LiCrO}_{2}$ and $\mathrm{LiFeO}_{2}$ were found to be the major constituents of the corrosion product on an AISI 316 anode housing. It was also found that a $\mathrm{LiAlO}_{2}$ coating on AISI 316 hardware offered good corrosion protection in a molten carbonate environment, especially in the wet seal areas.

Since the corrosion resistance. of alloys subjected to a mixture of molten carbonate salts appears to be dependent on the formation of a protective $\mathrm{LiCrO}_{2}$ film, any contaminant which interferes with the formation of this protective layer would be expected to lower the alloys corrosion resistance. The detrimental effects of sulfide in mixtures of alkali metal carbonate melts in the Molten Carbonate Process for removal of the oxides of sulfur from power plant stack gases [1] and in recovery processes for spent : pulping liquors in the paper industry [10-12] is documented in the literature. The corrosion rates in sulfur-containing melts was found to be orders of magnitude higher than in pure carbonates. The effect of halides on metal corrosion in a molten carbonate environment is not as well documented, at least in recent literature, but the available data also indicates that accelerated corrosion rates can be expected.

Investigators at General Electric [I] found that in a fuel cell molten carbonate environment addition of $100 \mathrm{ppm}$ of $\mathrm{HCl}$ caused severe corrosion problems of cathode AISI 316 hardware at $1200^{\circ} \mathrm{F}\left(650^{\circ} \mathrm{C}\right)$. The corrosion was severe enough to cause almost complete plugging of the gas passages with corrosion products. The corrosion was extensive at the inlet side of the current collector and extended for only a few millimeter downstream. Addition of $10 \mathrm{ppm} \mathrm{HCl}$ was not a problem on the cathode side at $1200^{\circ} \mathrm{F}$ $\left(650^{\circ} \mathrm{C}\right)$ but was expected to cause corrosion problems at lower temperatures.

On the anode side, there was no evidence of chloride induced corrosion of the anode or cell hardware after one month of exposure to a melt containing 
$10 \mathrm{ppm} \mathrm{HCl.} \mathrm{Thermodynamic} \mathrm{calculations} \mathrm{supported} \mathrm{these} \mathrm{results} \mathrm{at} 1200^{\circ} \mathrm{F}$ $\left(650^{\circ} \mathrm{C}\right)$. However, it was predicted that $100 \mathrm{ppm} \mathrm{HCl}$ would cause chlorination of anode hardware at $662^{\circ} \mathrm{F}\left(350^{\circ} \mathrm{C}\right)$.

In the heat treating industry, molten mixtures of carbonates, chlorides, and other salts are used for heat treating baths for steels and non-ferrous alloys. For example, the Metals Handbook [13] lists a salt bath conforming to a military specification;-MIL-S-10699, which consists of a mixture of equal amounts of $\mathrm{Na}_{2} \mathrm{CO}_{3}$ and $\mathrm{KCl}$, and is used for tempering steel in the temperature range $1150-1700^{\circ} \mathrm{F}\left(621-927^{\circ} \mathrm{C}\right)$. Compatibility studies conducted on alloys of which contaminant vessels for these molten salt mixtures are made should provide pertinent information to the present study. Although no specific references are given in the Metals Handbook, the recommended materials of construction for salt bath pots are alloys with 30 - 40 percent $\mathrm{Ni}$ and 15 - 23 percent $\mathrm{Cr}$, such as RA 330 and Incoloy. The Corrosion Handbook [14] recommends the use of $14^{\circ}$ - 18 percent $C r$, nickel-base alloys as materials of construction for fused salt pots to nontain $\mathrm{KCl} / \mathrm{Na}_{2} \mathrm{CO}_{3}$.

Jackson and LaChance [15] evaluated a number of Fe-Ni-Cr cast alloys in molten neutral heat treatment salts with 50 percent $\mathrm{Na}_{2} \mathrm{CO}_{3}$ - 50 percent $\mathrm{KCl}$ salt differed significantly from that in the $\mathrm{NaCl}-\mathrm{KCl}$ or $\mathrm{NaCl}-\mathrm{KCl}^{-\mathrm{BaCl}_{2}}$ salt mixtures. They plotted the corrosion rate vs. percent of chromium or nickel in the alloy and showed that in the $\mathrm{Na}_{2} \mathrm{CO}_{3}-\mathrm{KCl}$ molten salt alloys which had a chromium concentration of $26-36$ percent were most susceptible to corrosion as were alloys with $10-15$ percent nickel. The Hil alloy $(25$ $\mathrm{Cr}-12 \mathrm{Ni}$ ) was, therefore, ruled out as a material of construction for salt pots. The HK-40 (25 Cr-20 Ni), HT (15 Cr-35 Ni), and HW $(12 \mathrm{Cr}-60 \mathrm{Ni})$ performed well in this service.

In their study of iron in melts containing sodium halides and carbonates at $700 \mathrm{C}$, Kochergin and Ignat'eva [16] found an activating effect of $\mathrm{Cl}^{-}$ and $\mathrm{F}^{-}$ions on oxidation of iron which was attributed to their adsorptive 
displacement of oxygen from the iron surface. They found that the rate of oxidation in a $\mathrm{Na}_{2} \mathrm{CO}_{3}-50$ percent $\mathrm{NaF}$ melt was slightly higher than in a $\mathrm{Na}_{2} \mathrm{CO}_{3}-50$ percent $\mathrm{NaCl}$ melt. They also noted that the thermal dissociation of sodium carbonate at $800^{\circ} \mathrm{C}$ increased with halide addition. The fluoride had a more pronounced effect than the chloride.

Baraka and Baraka [17] studied the behavior of nickel in halide-containing $(\mathrm{Na}, \mathrm{K}) \mathrm{NO}_{3}$ melts at $752^{\circ} \mathrm{F}=\left(400^{\circ} \mathrm{C}\right)$. They found that corrosion of nickel increased in the presence of $\mathrm{Cl}^{-}$and $\mathrm{Br}^{-}$but decreased in the presence of $\mathrm{I}^{-}$. They noted that the oxidation interaction at constant temperature occurs at a rate which was dependent on the nature of the halide ion present. The rate of this oxidation process increased generally in the order $\mathrm{Cl}^{-}$, $\mathrm{Br}^{-}, \mathrm{I}^{-}$and was attributed to the increase of $\mathrm{O}^{-}$in the melt. The presence of $\mathrm{F}^{-}$greatly increased the rate of $\mathrm{Ni}$ corrosion. This was attributed to the small size of the fluoride ion and its high reactivity. It was postulated that fluoride penetrates the oxide layer and forms insoluble nickel fluoride.

Several references were found in which the effects of gaseous HCl on oxidation of Fe-Cr-Ni alloys were studied. Although in a molten carbonate fuel cell environment incoming gaseous $\mathrm{HCl}$ would be expected to be converted to lithium and potassium chlorides, these data provide pertinent information relating to corrosion problems which will be encountered in the inlet liuss to the fuel cell. Ellcott and Marsh [18] have shown that introduction of $500 \mathrm{ppm} \mathrm{HCl}(\mathrm{g})$ into moist air significantly reduces the oxidation resistance of Incoloy 800 alloy at $1472^{\circ} \mathrm{F}\left(800^{\circ} \mathrm{C}\right)$, especially during temperature cycling. The accelerated corrosion was attributed to the combined presence of voids and chloride-enriched phase at the alloy-oxide interface. This resulted in reduced adhesive strength of the oxide and severe oxidation rates in presence of $\mathrm{HCl}(\mathrm{g})$ were increased. This was attributed to enhanced rates of transport of reactive components to the oxidizing surface and to some reactive 
volatization. It was suggested that the presence of a chloride-rich region beneath the oxide facilitated such transport.

Similar results were obtained by Hossain and Saunders [19] in their study of the oxidation of a Ni-Cr-Al alloy at $1562^{\circ} \mathrm{F}\left(850^{\circ} \mathrm{C}\right)$ in air containing $\mathrm{HCl}$ gas. In moist air, $\mathrm{HCl}$ gas caused the oxide formed on the Ni-Cr-Al alloy to crack during the early stages of growth and extensive blistering and spalliny uf the oxlde occurred on cooling. In dry air rontaining hGl, no cracking was observed but the oxide blistered and spalled on cooling. In dry or moist air free from $\mathrm{HCl}$, an adherent protective oxide formed which did not spall. They attributed the oxide cracking at temperature to the production of $\mathrm{H}_{2}$ by reaction to $\mathrm{Cr}$ and $\mathrm{Al}$ in the alloy with water vapor and removal of $\mathrm{NiO}$ as $\mathrm{NiCl}_{2}$ by reaction with $\mathrm{HCl}$ gas. The $\mathrm{H}_{2}$, thus produced, dissolved in the alloy at temperature; but on cooling, hydrogen was released causing the oxide to blister and spall. Pre-oxidation of the alloy before subjecting to an HCl-containing environment eliminated the effects of $\mathrm{HCl}$ in short-term, isothormal tcsts.

Results of this survey indicate that halides in a molten carbonate fuel cell w111 accelerate the corrosion rate of structural alloys. The survey also shows that very little work was done to specifically evaluate the effects of halide contamination in a molten carbonate fuel cell environment. This points out the need for additional work in this area to characterize better and define the mechanisms involved.

\section{THERMODYNAMIC ANALYSIS}

Although thermodynamics cannot be used alone to determine the modes of decay due to halides, it does provide a guide to the modes to be anticipated. Where thermodynamic properties were found, calculations were peformed to determine the equilibrium composition of fuel cell components in the presence of chloride and fluoride. Data were available to calculate the equilibrium 
composition of the electrolyte in the presence of hydrogen chloride and fluoride, the vapor pressures of the alkali metal chlorides and fluorides over the electrolyte, nickel anode potential for chloride formation, and Iithium aluminate matrix material composition.

\section{Electrolyte}

Halides in the form of either HCl or HF are anticipated to react with the molten carbonate electrolyte by:

$$
\begin{aligned}
& 2 \mathrm{HCl}(\mathrm{g})+\mathrm{M}_{2} \mathrm{CO}_{3}(1) \rightarrow 2 \mathrm{MCl}(1)+\mathrm{H}_{2} \mathrm{O}(\mathrm{g})+\mathrm{CO}_{2}(\mathrm{~g}) \\
& 2 \mathrm{HF}(\mathrm{g})+\mathrm{M}_{2} \mathrm{CO}_{3}(1) \rightarrow 2 \mathrm{MF}(1)+\mathrm{H}_{2} \mathrm{O}(\mathrm{g})+\mathrm{CO}_{2}(\mathrm{~g})
\end{aligned}
$$

where $M$ represents either lithium (Li) or potassium (K).

Halides accelerate elecrolyte loss by converting the carbonate to gaseous carbon dioxide and by vaporization of $M C l$ or $M F$. In the gaseous state, MCl and MF can polymerize. Equilibrium constants for reactions $1-1, \ddot{1}-2$, vaporization and polymerization were calculated and are given in Appeñdix $A$.

From these equilibrium constants, the equilibrium vapor pressures can be determined and compared with available data or correlations. In Figure $1-1$, these calculated vapor pressures, ${ }^{\mathrm{P}_{\mathrm{KCl}}}+{ }^{\mathrm{P}_{\mathrm{K}}} \mathrm{Cl}_{2}$ and ${ }^{\mathrm{P}_{\mathrm{LiCl}}+}$

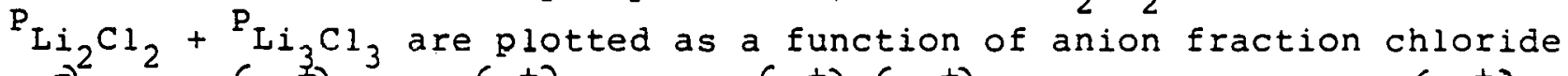
$\left\{\mathrm{Cl}^{-}\right\}^{2}$ with $\left\{\mathrm{Li}^{+}\right\}=1,\left\{\mathrm{~K}^{+}\right\}=1$ and $\left\{\mathrm{K}^{+}\right\} /\left\{\mathrm{Li}^{+}\right\}=0.38 / 0.62$. Here $\left\{\mathrm{Li}^{+}\right\}$and $\left\{\mathrm{K}^{+}\right\}$ are the cation fractions of lithium and potassium respectively. The pure alkali-metal chloride data were obtained from Janz et al. [20j. The value for $\mathrm{KCl}$ is an extrapolation out of the range given by janz et al.

As can be seen from Figure 1-l, the calculated vapor pressure of the pure chlorides are in reasonably good agreement with data. A similar plot for 
fluoride is found in Figure 1-2. The experimental results for fluorides shown in Figure 1-2 are extrapolations and are in less satisfactory agreement with calculations.

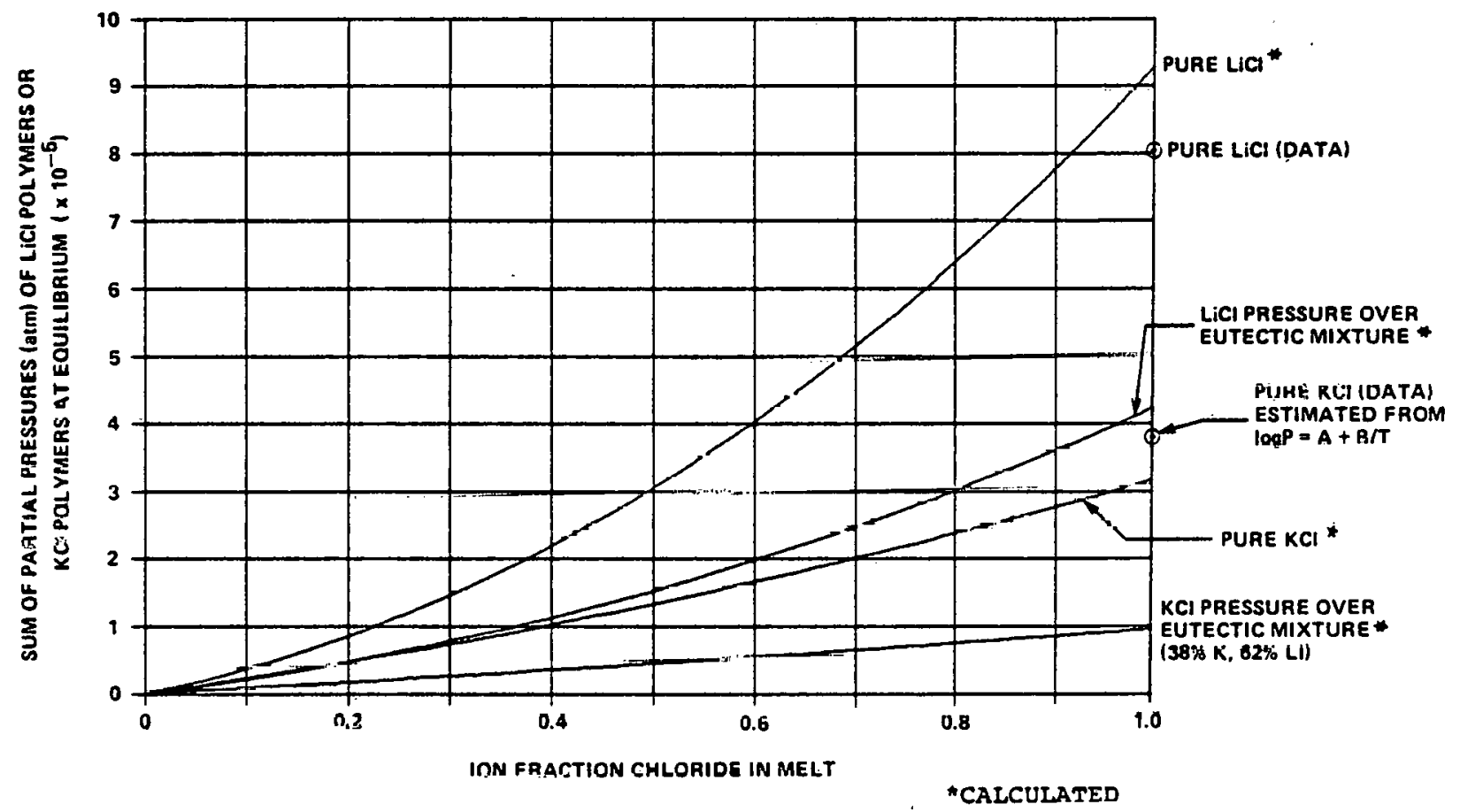

Figure 1-1. Alkali-Metal Chloride Vapor Pressure as a Function of Chloride in Melt 


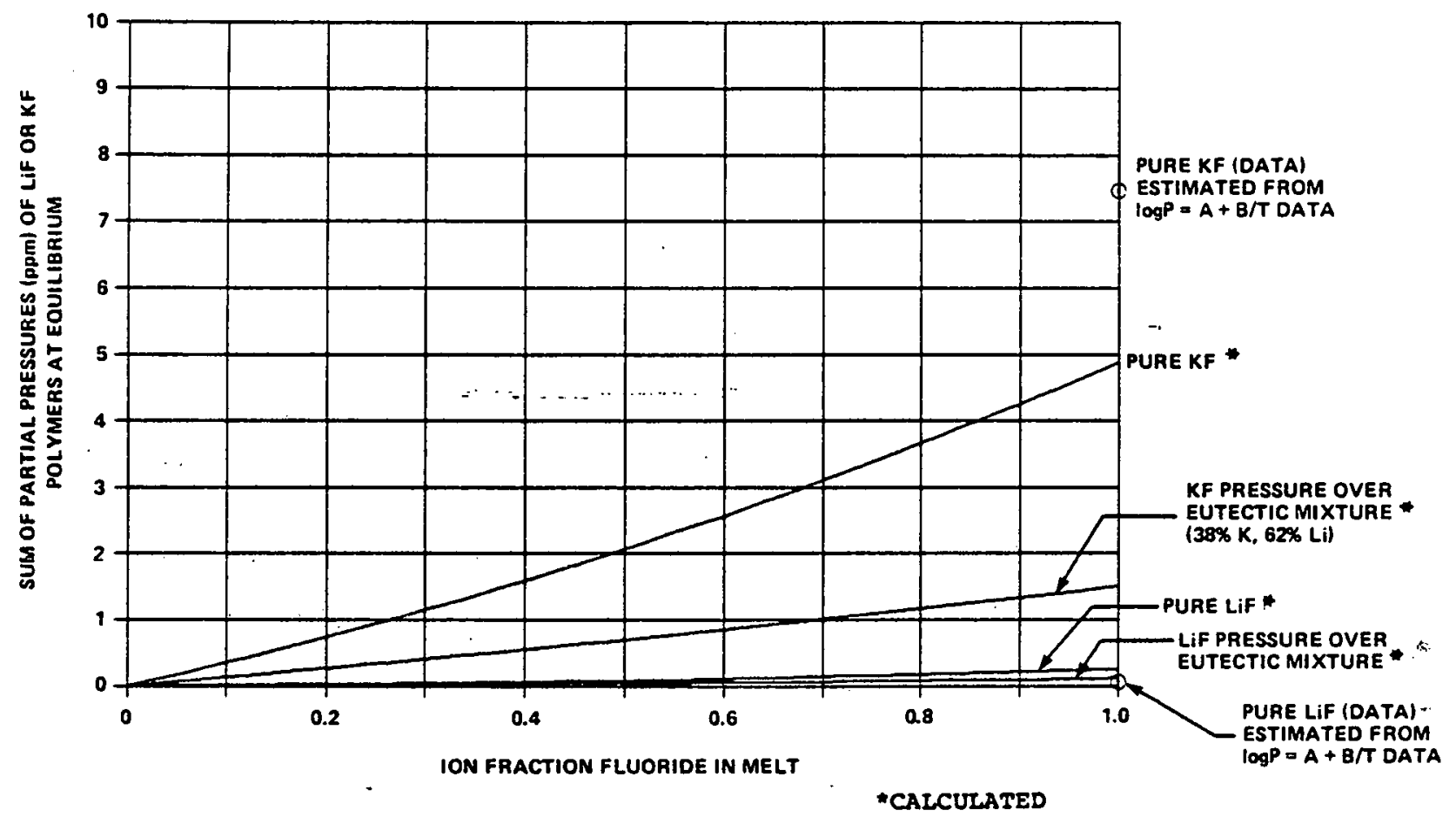

Figure 1-2. Alkali-Metal Fluoride Vapor Pressure ;* as a Function of Fluoride in Melt.

At steady state, the amount of halide reacting with the electrolyte will equal the amount of halide leaving the electrolyte. Therefore, at any given halide concentration in the gas phase, it is possible to calculate the anion fraction halide in the melt.

In order to obtain an estimate of the steady state halide concentration in a cell, a set of operating conditions and a system configuration were selected which include reactant compositions associated with an $\mathrm{O}_{2}$-blown Texaco coal gasifier molten carbonate fuel cell power plant. The operating conditions are: 
Temperature $=650^{\circ} \mathrm{C}$

Pressure $=1$ atm

Oxidant composition: $8.98 \mathrm{CO}_{2}, 11.7 \% \mathrm{O}_{2}, 79.58 \mathrm{~N}_{2}-55^{\circ} \mathrm{C}$ dew point Oxidant utilization $=378$

Fuel composition $=56.2 \% \mathrm{H}_{2}, 10.5 \% \mathrm{CO}, 33.48 \mathrm{CO}_{2}-80^{\circ} \mathrm{C}$ dew point

Fuel utilization $=85 \%\left(\mathrm{H}_{2}+\mathrm{CO}\right)$

Current density $=172 \mathrm{ma} / \mathrm{cm}^{2}$

Halide was assumed to enter the stack in the fuel gas. The fuel effluent from the stack was then completely burned in the inlet oxidant without venting so all of the halide leaving in the fuel would be returned to the stack in the oxidant stream. Under this situation, when steady state is reached in the stack, the mass flux of halide leaving the stack in the oxidant stream must be equal to that in the inlet fuel. The concentration of halide in the oxidant effluent is much less than that in the fuel inlet because the ratio of oxidant-to-fuel volume flow rates is 10.7 in this case.

'The electrolyte was considered to be homoqeneous in composition in this calculation. In actual practice, the halides would be preferentially scrubbed from the fuel inlet stream near the fuel inlct location. Alsu, a gradient in halide concentration would exist between the anode and cathode due to different concentrations in the gas streams, the production of carbonate ions at the cathode, and the consumption of carbonate inns at the anode. The oxidant effluent was considered to be in equilihrium with this uniform electrolyte composition.

The steady state compositions obtained using these assumptions are presented in Table 1-l as a function of the halide coneentration in the fuel inlet. For the case of $10 \mathrm{ppm}$ chloride and $10 \mathrm{ppm}$ fluoride in the fuel inlet stream, $0.933 \mathrm{ppm}$ chloride and $0.933 \mathrm{ppm}$ fluoride would be present in the oxidant effluent. These effluent concentrations are in equilibrium 
with an electrolyte containing 0.031 anion fraction chloride and 0.56 anion fraction fluoride. Results for other concentrations in the oxidant gas are presented in Figure 1-3.

Table 1-1. Steady State Halide Concentrations

in Electrolyte

\begin{tabular}{cccc}
$\begin{array}{c}\text { ppmv Halide } \\
\text { in Fue }\end{array}$ & $\begin{array}{c}\text { ppm Halide } \\
\text { in Oxidant }\end{array}$ & $\begin{array}{c}\left\{\mathrm{Cl}^{-}\right\} \text {in } \\
\text { Cathode Melt }\end{array}$ & $\begin{array}{c}\left\{\mathrm{F}^{-}\right\} \text {in } \\
\text { Cathode M }\end{array}$ \\
\cline { 1 - 2 } 1 & 0.0933 & $<0.01$ & 0.067 \\
5 & 0.4665 & 0.016 & 0.31 \\
10 & 0.933 & 0.031 & 0.56 \\
50 & 4.665 & 0.13 & 1 \\
100 & 9.33 & 0.23 & 1
\end{tabular}




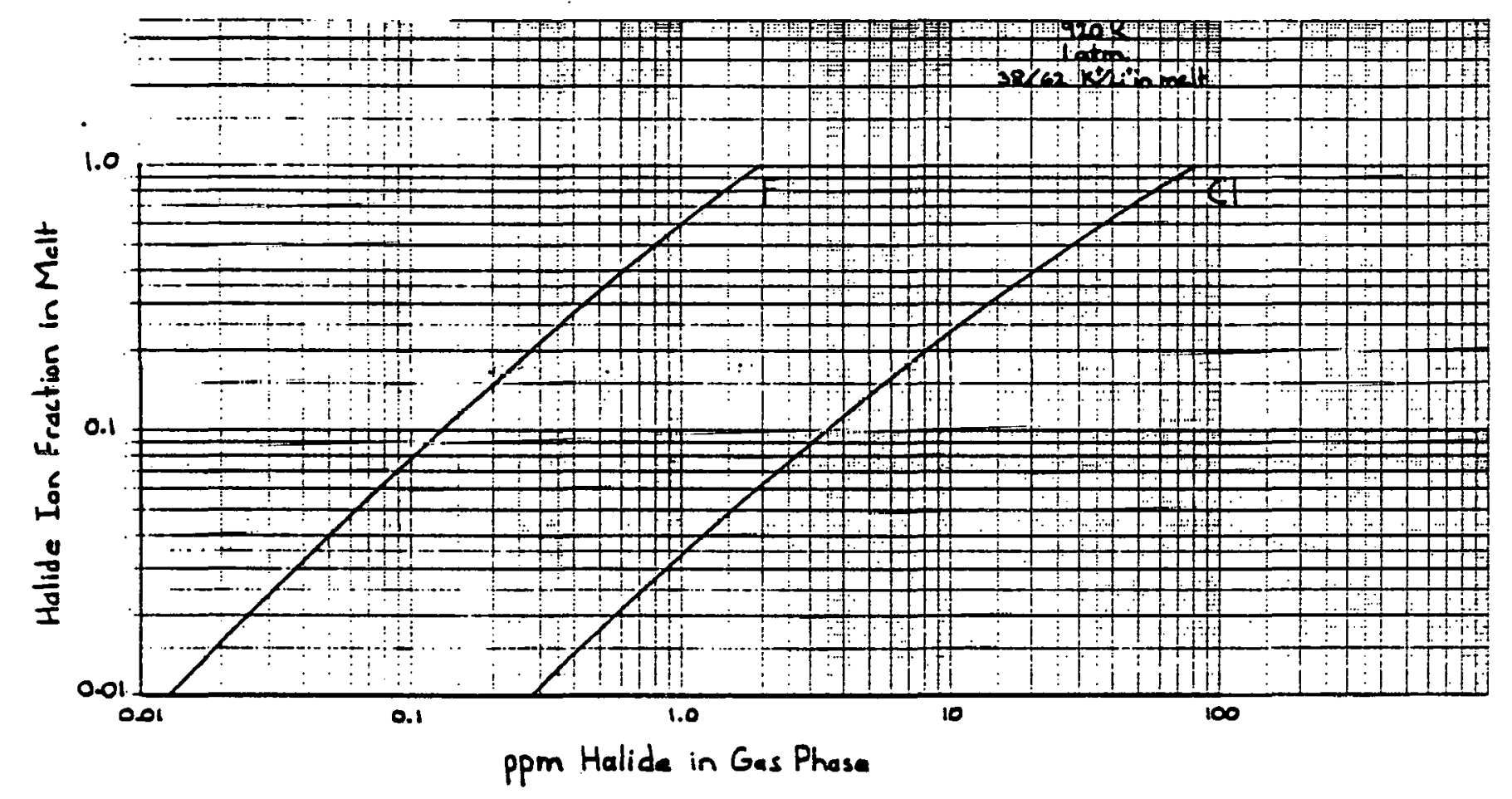

Figure 1-3. Steady State Halide Balance

At these operating conditions, assuming that the cell contains $13 \mathrm{~g}$ of $\mathrm{Li}_{2} \mathrm{CO}_{3} / \mathrm{K}_{2} \mathrm{CO}_{3}(62 / 38$ molar 8$)$ electrolyte and that no halide leaves the cell in the oxidant effluent prior to reaching steady state, the inlet flux of each halide in the fuel is sufficient to completely convert the electrolyte in 16,200 hours. Since the steady state concentration of. chloride is only. 0.031 ion fraction, steady state for chloride would be reached in the order of 500 hours. For fluoride, since the steady state ion fraction is much higher at 0.56 , the time for fluoride conversion is of the order of 9000 hours. 
These results indicate that chloride and fluoride may have different decay modes. Chloride will achieve steady state relatively quickly with a small chloride ion concentration. Electrolyte will be lost by evaporation into the oxidant effluent. Conversely, fluoride will reach steady state slowly with a large electrolyte conversion and a slow rate of electrolyte loss. The large electrolyte conversion could result in a gradient in electrolyte composition between the anode and cathode as mentioned previously. This composition difference would result in a performance loss due to an electrolyte concentration polarization, a liquid-junction-potential effect, and perhaps increased cell internal resistance and electrode polarizations.

This case considered an operating pressure of 1 atm. At 10 atm, the volume flux of oxidant from the cell would be reduced by a factor of 10 due to the increased oxidant density. A much higher electrolyte conversion would result before the flow of halide from the cell would balance the input flow.

\section{Anode}

The nickel anode is expected to react with $\mathrm{HCl}$ by: $\mathrm{Ni}(\mathrm{s})+2 \mathrm{HCl}(\mathrm{g}) \rightarrow$ $\mathrm{NiCl}_{2}(\mathrm{~s})+\mathrm{H}_{2}(\mathrm{~g})[4]$.

This reaction will occur only if $\mathrm{P}_{\mathrm{H}_{2}} / \mathrm{P}^{2} \mathrm{HCl}<\mathrm{Keq}$, where

$$
\operatorname{Keq}=\exp \left[\frac{1}{R T}\left(\mu_{N_{i}}^{0,5}+2 \mu_{H<1}^{0,0}-\mu_{N_{i C I_{2}}}^{0,5}-\mu_{H_{2}}^{0,0}\right)\right]
$$

At a given hydrogen pressure the anode will be at a potential defined by the equation:

$$
E=E^{\circ}+\frac{R T}{2 F} \ln \left(\frac{P_{\mathrm{H}_{2} O} P_{\mathrm{CO}_{2}}}{P_{H_{2}}}\right)-\frac{R T}{2 F} \ln \left(P_{\mathrm{O}_{2}}^{1 / 2} P_{\text {CO }}\right)_{\text {RTF. ELECTRODE }}
$$

where the potential is referenced to an $\mathrm{O}_{2} / \mathrm{CO}_{2}$ reference electrode, 


$$
\begin{aligned}
& \mathrm{E}^{\circ}=\text { potential at standard states of unity activities } \\
& \mathrm{F}=\text { Faraday's constant }(96487 \text { coulombs/equivalent) }
\end{aligned}
$$

Combining $(1-3)$ and $(1-4)$ :

$E=E^{0}+\frac{R T}{2 F} \ln \left(\frac{P_{\mathrm{H}_{2} \mathrm{O}} P_{\mathrm{CO}_{2}}}{P_{H C 1}^{2}}\right)-\frac{R T}{2 F} \ln \left(P_{\mathrm{O}_{2}}^{1 / 2} P_{\mathrm{OO}}\right)_{\text {REF. ELECTRODE }}$

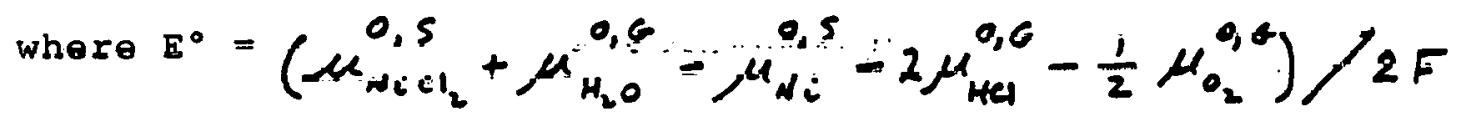

Figure 1-4 presents the potential at which nickel chloride will form at the anode as a function of $\mathrm{HCl}$ concentration in the gas phase using a $2 / 3$ $\operatorname{atm} \mathrm{CO}_{2}, 1 / 3$ atm $\mathrm{O}_{2}$ reference gas. The oxidation potential of the anode is shown for comparison. Similar calculations for the cathode are impossible because of the lack of thermodynamic data on reaction products of lithiated nickel oxide and the halides. For example, chloride ions may enter the crystal lattice of lithiated nickel oxide and change its properties. 


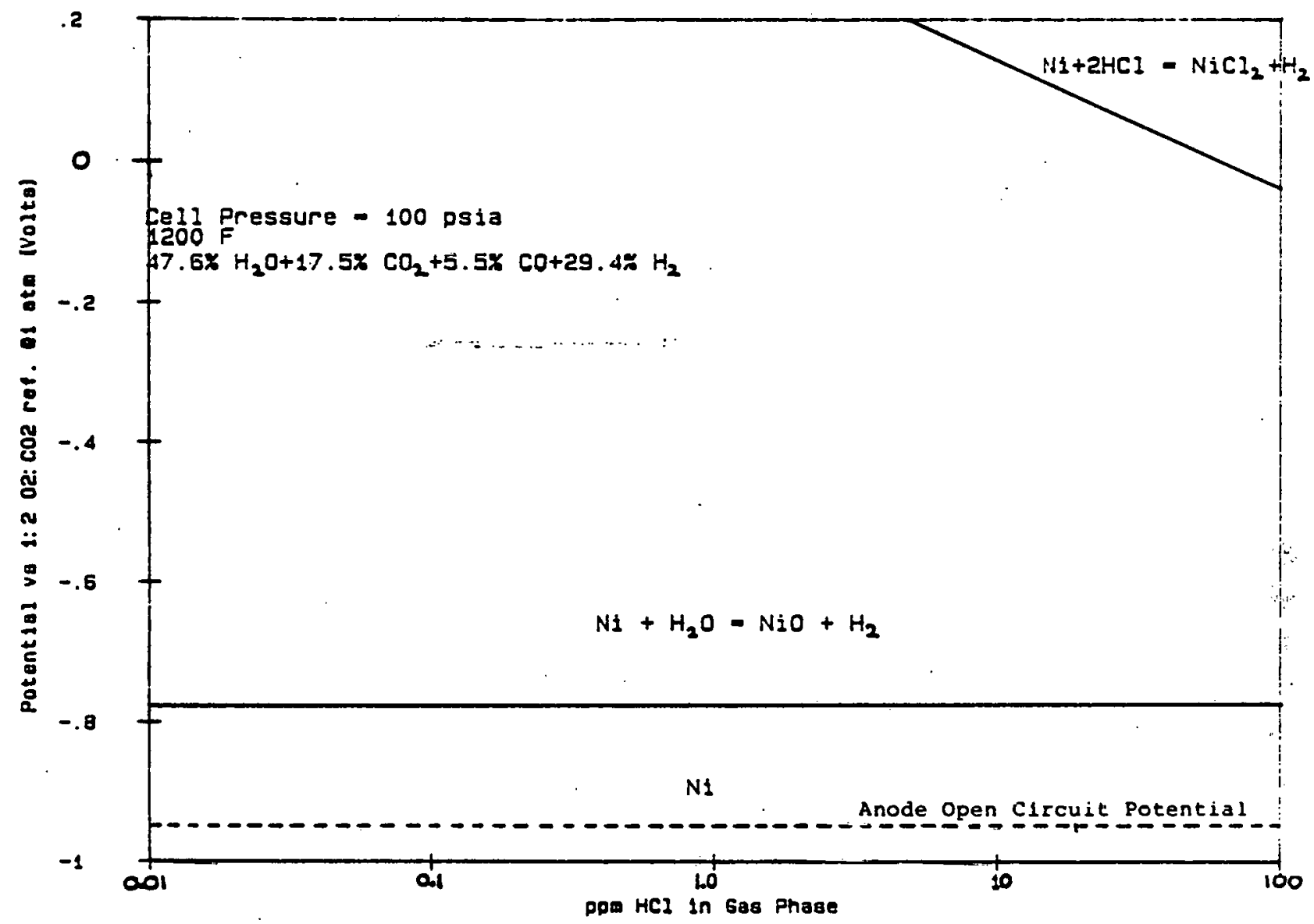

Figure 1-4. Nickel Electrode Degradation by $\mathrm{HCl}$

\section{Matrix}

Two possible matrix-halide reactions were studied thermodynamically:

$$
\begin{aligned}
& \mathrm{LiAlO}_{2}(\mathrm{~s})+4 \mathrm{HF}(\mathrm{g}) \rightarrow \mathrm{LiAlF}_{4}(\mathrm{~g})+2 \mathrm{H}_{2} \mathrm{O}(\mathrm{g}) \\
& \mathrm{LiAlO}_{2}(\mathrm{~s})+4 \mathrm{HF}(\mathrm{g})+2 \mathrm{LiF}(\mathrm{l}) \rightarrow \mathrm{Li}_{3} \mathrm{AlF}_{6}(\mathrm{~s})+2 \mathrm{H}_{2} \mathrm{O}(\mathrm{g})
\end{aligned}
$$


The equilibrium constant for equation (1-5) is given by:

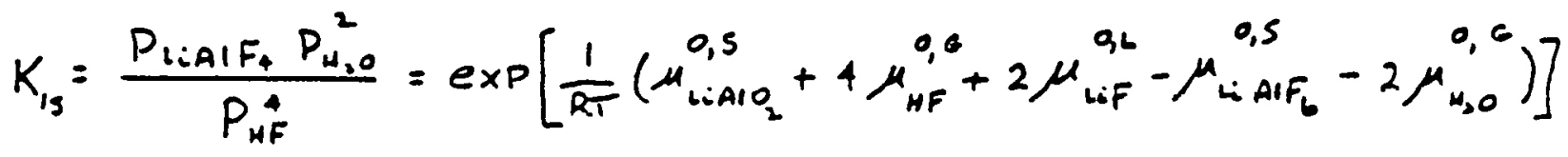

At $900^{\circ} \mathrm{K}, \mathrm{K}_{1-5}=0.0863$, but because $\mathrm{P}_{\mathrm{HF}}$ is taken to the fourth power, equation $(1-5)$ will not be important at the HF concentrations of interçt.

'the equilibrium constant for equation $(1-6)$ is given hy:

$$
\begin{aligned}
& K_{16}=\frac{P_{H_{20}}^{2}}{P_{M F}^{4}\left\{L_{i}+\right\}^{2}\{F-\}^{2}}=\operatorname{exP}\left[\frac { 1 } { R T } \left(\mu_{L i A 1 O_{2}}^{0,5}+4 \mu_{H F}^{0, G}+2 \mu_{L i F}^{0, L}\right.\right. \\
& \left.\left.-\mu_{L i_{f} A F_{b}}^{a s}-2 \mu_{H_{b}}^{0,0}\right)\right]
\end{aligned}
$$

At $900^{\circ} \mathrm{K}, \mathrm{K}_{1=6}=8.9 \times 10^{6}$, meaning that the reaction for equation $(1-6)$ could be significant. 
DISCUSSION

The literature survey and thermodynamic analyses indicate that hydrogen chloride and hydrogen fluoride present in gasified coal can affect the performance of molten carbonate fuel cells in several ways.

- Electrolyte conversion -- The thermodynamic calculations indicate that $\mathrm{HCl}$ or $\mathrm{HF}$ will tend to react essentially completely with the molten carbonate electrolyte to form chlorides and fluorides. The presence of chloride formation was confirmed by the presence of chlorides in the post-test electrolyte of a cell which was tested with $\mathrm{HCl}$ in the reactants.

- Electrolyte vaporization -- Theoretical and experimental vapor pressures of pure $\mathrm{KCl}$ and $\mathrm{LiCl}$ agree reasonably well, giving confidence that the calculated vapor pressures of chlorides and fluorides above partially converted molten carbonate electrolyte are reasonably accurate. These calculations indicate that conversion of the electrolyte will result in an increased rate of vaporization. For the case of chloride, the increased vaporization will take place with a relatively small degree of conversion at 1 atm pressure; whereas for fluoride, a large conversion could take place before increased vaporization would occur. Conversion becomes more important as a decay mode as pressure is increased. The importance of vaporization as a decay mode is attested to by the large electrolyte loss experienced in the cell tested at United Technologies Corporation (UTC) with $\mathrm{HCl}$ in the fuel.

- Anode poisoning -- Although the thermodynamic analysis and post-test inspection of anodes which operated on $\mathrm{HCl}$ - contalning fuel indicate that nickel chloride should not form, poisoning of the anode reaction apparently occurred in both the General Electric (GE) and UTC tests. since carbonate jons are consumed at the anode, the replacement of some of the carbonate ions by chloride ions may slow the anode reaction. 
- Cathode Current Collector Corrosion -- The literature survey on the effect of chlorides in the corrosion caused by alkali metal salts indicates that the chlorides increase corrosion. The post-test inspection of cell components tested with $\mathrm{HCl}$ in the reactants confirm that this increased corrosion also occurs in the fuel cell environment.

- Cathode Changes -- Thermodynamic calculations indicate that $\mathrm{NiCl}_{2} \mathrm{Can}$ form at cathude potential's with adequately high $\mathrm{HCl}$ pressures. Prior to the formation of chloride from the oxide, however, some chloride may enter the lattice of the lithiated nickel oxide and change its properties. A change in cathode morphology was noted in a GE cell test.

- Matrix Material Changes -- Both thermodynamic calculations and post-test analysis of a GE cell indicate that lithium aluminate may not be stable above certain concentrations of halide in the electrolyte. 


\section{CONCLUSIONS}

Molten carbonate fuel cells are anticipated to be very sensitive to the presence of chlorides and fluorides in the fuel gas. Conversion of the electrolyte from carbonate to chloride and fluoride is anticipated. For the case of chloride, an accelerated rate of electrolyte loss will occur; whereas for fluoride, the electrolyte loss rate will not be increased as much. The conversion of the electrolyte in both cases, however, might lead to anode poisoning, cathode and matrix material changes, and increased cathode current collector corrosion, depending on the degree of electrolyte conversion. An electrolyte concentration polarization, liquid junction potential effect and increased internal resistance can occur due to the different electrolyte composition in the anode and cathode. 
TASK 2 - TEST PLAN

Using the understanding of the effects of chlorides and fluorides obtained in the literature survey and thermodynamic analyses as presented in the previous section, a test plan was formulated for investigating the effects of these halides in Tasks 3 and 4 of this contract. Task 3 involved out-of-cell testing and Task 4 in-cell testing. These test plans were modified during the program to reflect changes in program emphasis and scope.

Hydrogen chloride in a molten carbonate reactant gas is anticipated to react quantitatively with the electrolyte to form chlorides. These chlorides will accelerate the corrosion of cathode-side components and lead to a conversion of the electrolyte until the rate of chloride loss balances the rate of input. The vapor pressure of the chlorides is expected to be high enough for these rates to be balanced with a relatively small conversion of the electrolyte from carbonate to chloride. The loss of electrolyte will be greatly accelerated due to the chloride.

Hydrogen fluoride in the reactant gases is anticipated to have somewhat different effects. The effect on corrosion of cathode-side components is unknown. Since the vapor pressures of lithium and potassium fluoride are much less than those of the chlorides, they will not evaporate from the electrolyte as rapidly, and conversion of the electrolyte will take place with much less electrolyte loss. Therefore, fluorides will affect performance more through electrolyte conversion than through electrolyte loss compared to chlorides.

Because of these anticipated effects, the out-of-cell tests in Task 3 were aimed at determining the effects of chloride and fluoride content in the electrolyte on the corrosion of cathode-side components and the measurement 
of the short-term performance effects in half-cell tests of both anode-side and cathode-side components.

In the out-of-cell corrosion experiments, three cathode current collector materials were corrosion tested for 1000 hours in molten carbonate electrolyte containing chloride and fluoride. The three materials were AISI 316 stainless steel, AISI 310 stainless steel, and Inconel 825 . The temperature of the test $\left(700^{\circ} \mathrm{Cl}\right.$ was above that of the cell $\left(650^{\circ} \mathrm{C}\right)$ in order to accelerate the corrosion rate. The electrolyte halide content was 3.1 anion percent halide, which corresponds to nne nnm halide in the gas phase for chloride and $0.04 \mathrm{ppm}$ halide in the gas phase for fluoride. The material samples were exposed to an oxidant gas which simulates that anticipated in a Texaco $\mathrm{O}_{2}$-blown coal gasifier fueled molten carbonate fuel cell power plant. Details of these plans can be found in Appendix $B$.

The anode-side half-cell performance tests consisted of the measurement of the overpotential as a function of current density for halide-free electrolyte and electrolyte containing 23 anion percent of each halide. For the chloride, this electrolyte composition results in a gas phase chloride concentration of $10 \mathrm{ppm}$, as shown in Eigure 1-3. For fluoride, the gas phase concentration is $0.3 \mathrm{ppm}$. The anode tests included all of the components on the anode side of the cell including the anode, bubble barriere, nurrent collectors and matrix.

The cathode-side half-cell performance tests also consisted of the measurement of overpotential as a function of current density for halide-free electrolyte and electrolyte containing 23 anion percent of each halide. In addition, a test was performed with 3.1 anion percent of chloride to determine the trend of performance change with chloride content. The cathode tests included all of the components on the cathode side of the cell including the cathode, current collector and matrix. Details of the components can be found in Appendix B. Both the anode and cathode tests 
were performed using reactants which simulated those in the Texaco $\mathrm{O}_{2}-$ blown coal gasifier power plant.

Post-test analyses were planned on the corrosion samples and components from the half-cell tests. Because the purpose of the corrosion tests was to determine the effect of halides in the surface corrosion layers, an extensive post-test analysis was planned for those layers including sectioning the samples and investigating the thickness, composition and conditions of the corrosion layers. Because of the shortness of the tests and the variable conditions in the half-cell tests, only visual inspection and component thicknesses were planned for post-test components.

For the in-cell tests in Task 4, data were desired on the performance decay of a bench-scale cell while operating with halide in the reactants. Some of these data were already available from the IFC contract No. DE-ACOl-79ET15440 with DOE. Although additional tests were initially planned, these tests were later removed from the plan. 
TASK 3 - OUT-OF-CELL TESTS

\section{HALF-CELL TESTS}

\section{Introduction}

A series of molten carbonate half-cell experiments were conducted to determine how chloride and fluoride in the electrolyte affect cell performance and the individual cell components. The objectives of the halfcell test program were: to measure how a concentration gradient of carbonate would affect cell performance, to determine how the amount of electrolyte in an electrode affects anode and cathode polarization in the presence of halides, and to obtain electrode overpotential as a function of current data for several chloride and fluoride concentrations for both anodes and cathodes. Half-cell testing also allowed a larger matrix of conditions to be tested in a given amount of time than could be done with full-cell subscale testing. Parts tested in the half-cell were the same as those that were used in full-cells and are described in the Test. Plan given in Appendix B.

\section{Experimental}

Two individual half-cell rigs were constructed: one to act as an anode half-cell, the other to act as a cathode half-cell, thereby enabling both electrodes to be run simultaneously. A schematic of a half-cell test rig is shown in Figure 3-1. Oxygen, nitrogen and carbon dioxide were supplied to the cathode half-cell through in-house gas lines. Hydrogen and carbon dioxide were supplied to the anode half-cell through in-house gas lines as well. Carbon monoxide was supplied to the anode half-cell through bottled gas. Both rigs also had the capability of running under diagnostic oxidant (a $1: 2 \mathrm{O}_{2}: \mathrm{CO}_{2}$ mixture). Running an anode and a cathode half-cell at the same time had several advantages over running either two anode or two cathode tests at the same time. This arrangement made optimum 


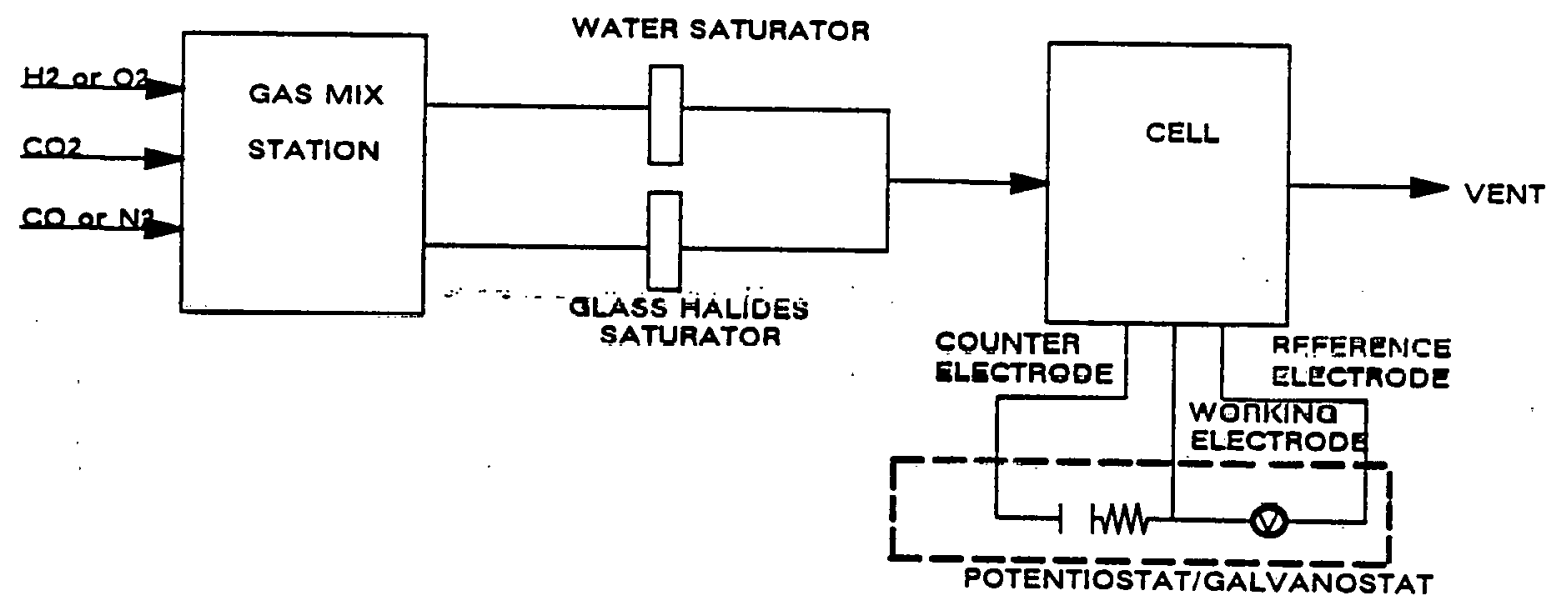

Figure 3-1. Half-Cell Schematic

use of the available gas flow controllers, minimized the number of times that the flow meters had to be calibrated and allowed both cells to use the same electrolyte at the same time. A separate oven was set up to manufacture electrolyte. Each gas flow rate was regulated and monitored by Matheson Gas Flow Controllers/Measurers. All tests were performed at 1 atm pressure and $650^{\circ} \mathrm{C}$ cell temperature.

Gases flowed in parallel through two saturators: one containing only water and the other containing a water-halide solution. This approach allowed for individual control of the dew point and halide concentration in the gas stream. After considering halide-containing gas bottles and permeation tubes, gas saturators were chosen to introduce halide into the gas stream because of their low cost. A computer program was developed, using halide and water vapor pressure vs. concentration and temperature tables, that defined the required flow rates of gases through each saturator, the 
temperature of each saturator, the concentration of halide solution in the halide saturator, and the method to maintain the halide concentration in the halide saturator in order to give the desired final flow rate, dew point and halide concentration in the combined gas stream. The water saturator used in each rig was a two-zone water saturator. The liquid in the lower half of the saturator was heated to $0.6^{\circ} \mathrm{C}$ above the desired dew point. The upper half of the saturator, which contained no liquid, was held at the desired dew point. The gas going into the saturator was dispersed into the liquid using a porous spherical.stone. This arrangement kept superheated water from entering the gas phase and gave very good control of the water dew point. The saturator was tried using the halide-water solution, but the fitting holding the gas-dispersion stone was made of brass and readily dissolved in $40^{\circ} \mathrm{C}, 10$ weight percent $\mathrm{HCl}$ solution. The halides saturator was replaced with an all-glass, single-zone saturator to introduce $\mathrm{HCl}$ into the cell. The single-zone saturator can be as accurate as the two-zone saturator if carefully calibrated and the liquid kept at a constant level. It was determined that an HF saturator was unnecessary, due to the low rate of fluoride loss from the cell, because of the low vapor pressures of KF and LiF. Gas-phase halide concentration was occasionally checked by bubbling the gas through a column of distilled water. Glass beads inthe column assured good liquid-vapor contact. The gas was bubbled through the column for a known length of time and the water in the column analyzed by Dionex ion chromatography for halide content. After the concentration of halide initially in the distilled water was subtracted from the Dionex results, the halide concentration in the gas phase could be calculated, assuming that all the halide in the gas phase was scrubbed out by the water and that the gas stream flow rate was known. Flow rates and halide saturator solution concentration were chosen so that the gas phase halide concentration would not vary by more than 5 percent over 350 hours of expected test life. Only $\mathrm{CO}_{2}$ flowed through the halides-water saturator in all the tests. 
Cell temperature was maintained using Lindberg Sola Basic crucible furnaces. Cell performance was monitored with a potentiostat/galvanostat designed and built at International Fuel Cells.

A sketch of the cathode half-cell configuration is shown in Figure 3-2. An AISI 310 stainless steel, shielded slot plate was placed on top of an alumina base to allow gases to escape from the counter electrode (CE). The counter electrode was a fine mesh gold screen with a small hole in the center, filled with an insulating material to support the tapes on top. The hole minimized undesired electric field lines between the working and counter electrode. Two $\mathrm{LiAlO}_{2}$ type matrices were placed on top of tho counter electrode and were filled to capacity with electrolyte. On top of the tapes was the nickel oxide cathode working electrode (WE). A hole was cut in the middle of the working electrode so that the gold wire reference electrode could contact the electrolyte. The reference electrode was shielded by an alumina tube. On top of the working electrode was another piece

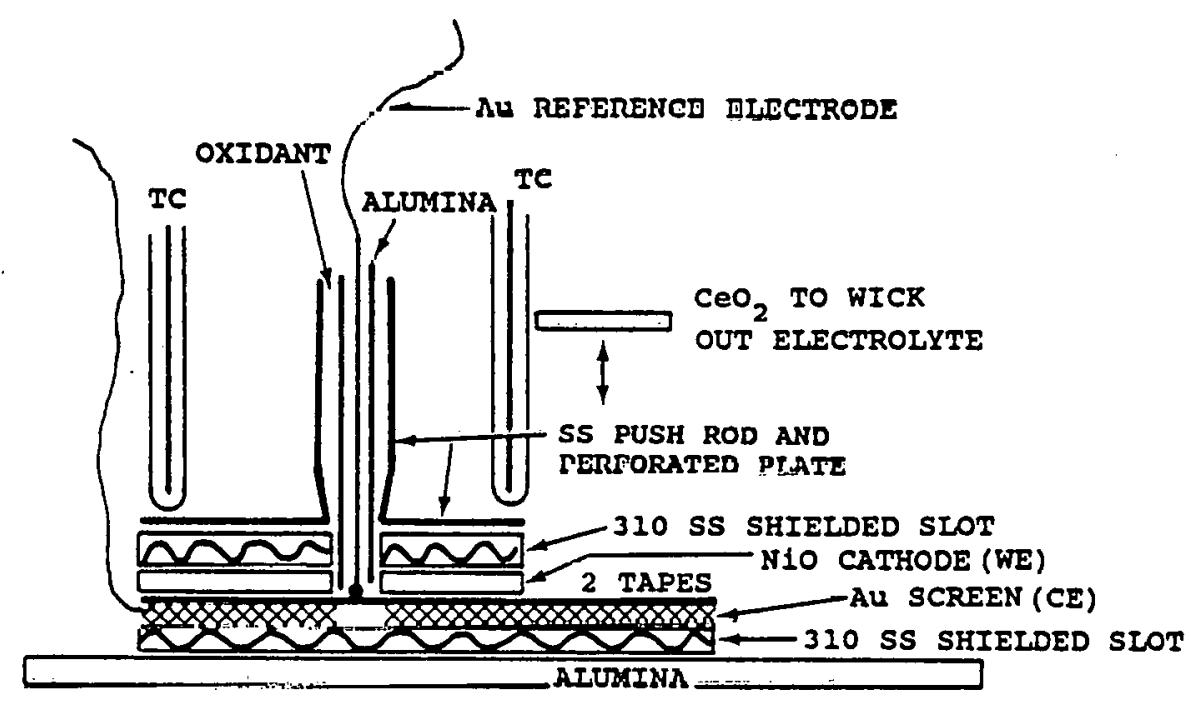

Figure 3-2. Cathode Half-Cell Configuration 
of AISI 310 stainless steel shielded slot plate, which functioned as a current collector. A hollow stainless steel push rod and perforated plate maintained contact between all the parts by applying pressure to the package and served as the working electrode's connection to the potentiostat/galvanostat. The oxidant flowed through the inside of the push rod. Cell temperature was monitored with alumina-covered thermocouples. An area of tape was left exposed so that electrolyte could be added or removed by the operator using a piece of fine pore $\mathrm{CeO}_{2}$ attached to the end of an alumina rod. Table 3-1 describes each component in more detail.

\section{TABLE 3-1: HALF-CELL COMPONENTS}

\section{COMPONENT}

Anode Current

Collector

Anode (Ribbed)

Fine Pore

Cathode Current

Collector

Cathode

Matrix
MATERIAL

Nickel

Nickel $+28 \mathrm{Cr}$

Nickel $+28 \mathrm{Cr}$

310 stainless steel

In-Situ Lithiated

Nickel-oxide
THICKNESS

$50 \mathrm{mils}$

0

POROSITY

$60 \mathrm{mils} \quad 0.50$

(27\% open cross-sectional area)

$4 \mathrm{mils}$

0.36

Base $=6 \mathrm{mils}$

Rib $=4$ mils

40 mils

0.773

2 Pieces

0.42

9 mils each

After the eighth cathode half-cell test, cathode material was placed under the matrix, as well as on top of it, to function as a better matrix support and counter electrode. The gold screen was retained as a counter electrode current collector. The anode half-cell configuration was similar to this cathode half-cell configuration and is shown in Figure 3-3. 


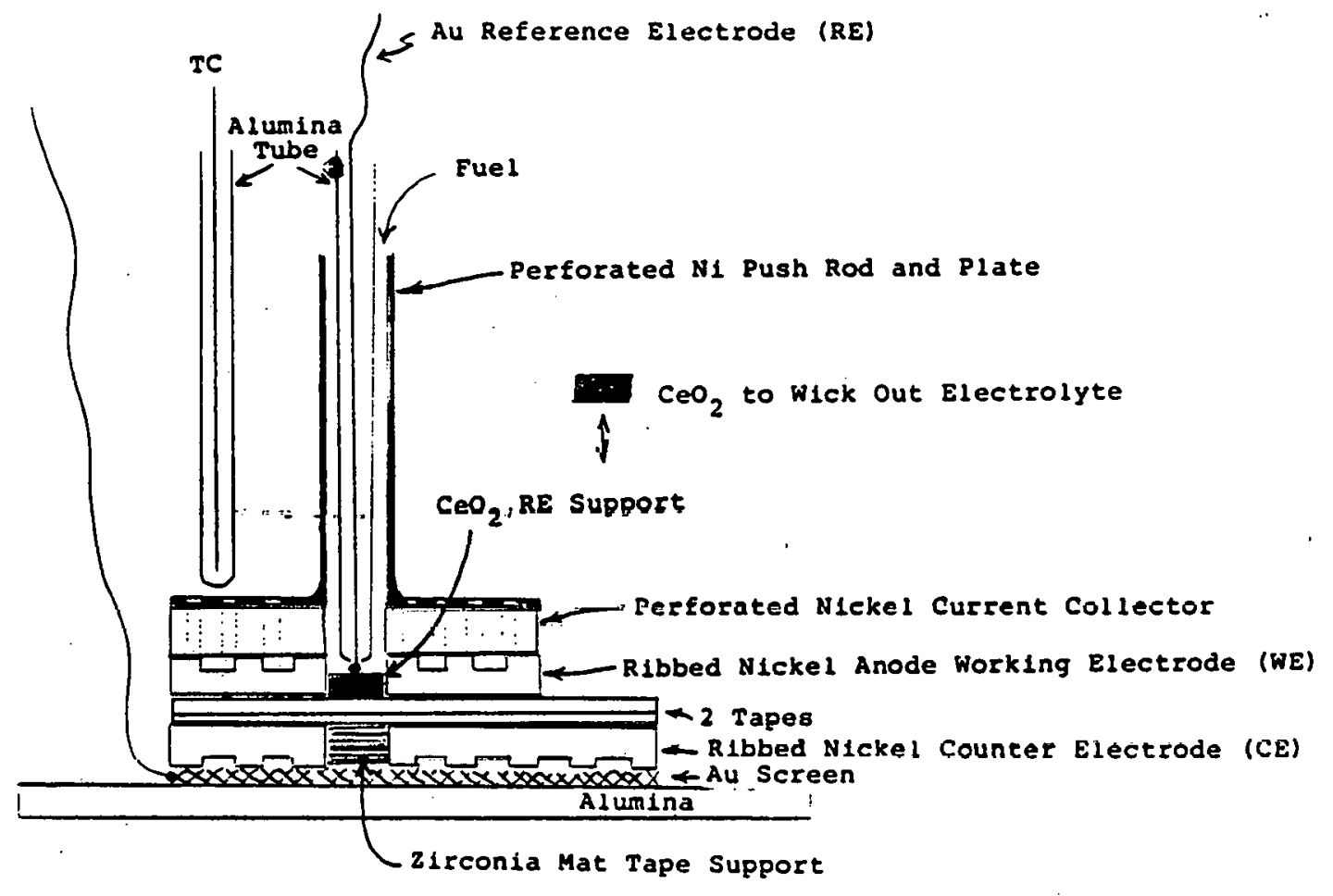

Figure 3-3. Anode Half-Cell Configuration

\section{Results and Discussion}

Prior to measuring the performance of anodes and cathodes in the half-cell, a series of experiments were performed to determine the effect of halides on the potential of the reference electrode. The effect of halide content on the reference electrode is important in determining the true potential of the working electrode. The halide effect is also important in determining whether any difference in potential between the reference electrode and working electrode is due to a difference in electrolyte composition.

An electrolyte halide ion concentration difference can also exist in a fuel cel1. Halides may enter the fuel cell system in the fuel and air supply and react with the electrolyte. Since carbonate ions are produced within the cell at the cathode and consumed at the anode, the cathode may be richer in carbonate than the anode. 
A set of experiments was performed to determine if a carbonate ion concentration gradient would follow theoretical predictions. The results from these experiments is useful in modeling how halides affect molten carbonate fuel cells.

The experimental setup shown in Figure 3-4 was used to perform these experiments. Four $\mathrm{LiAlO}_{2}$ matrices, each $3.18 \mathrm{~cm}$ by $2.54 \mathrm{~cm}$ by about $0.023 \mathrm{~cm}$ thick, were placed on an alumina sheet so that there was a $0.03 \mathrm{~cm}$ gap between two pairs of matrices. Matrices were stacked on top of each other so that a crack in any matrix would not separate a piece of matrix from the rest. Thick-walled alumina tubes were placed over each matrix. A $1: 2$ $\mathrm{O}_{2}: \mathrm{CO}_{2}$ gas mixture flowed through each tube at $10 \mathrm{standard} \mathrm{cc} / \mathrm{min}$. A small hole was cut near the bottom of each tube to allow the gas to exit. Each tube also contained a thermocouple, completely enclosed in an alumina tube, and a gold wire connecting a voltmeter with the matrix. This wire was also enclosed in alumina within the rig except for the tip in contact with the matrix. All experiments were performed at $650^{\circ} \mathrm{C}$ and ambient pressure and ran for 16 to 24 hours.

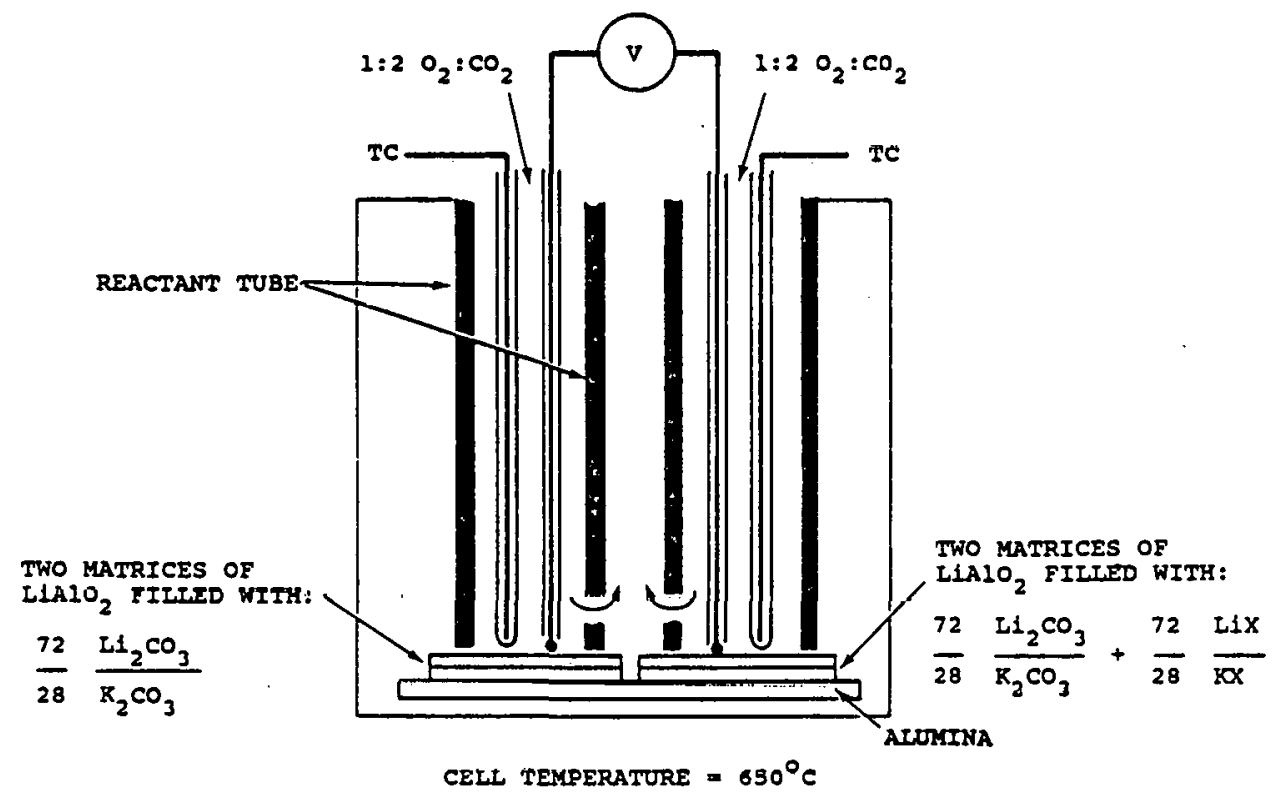

Figure 3-4. Experimental Half-Cell Setup 
Halide-free electrolyte was introduced through one tube and halidecontaminated electrolyte through the other. Both halide-free and halidecontaminated electrolyte had a 72:28 Li:k molar ratio. Enough electrolyte was introduced into each tube to fill each matrix to about 100 percent.

In the first trial, it was hoped that electrolyte would wick across the alumina to bridge the gap between the two pairs of matrices, but this never occurred. In the second trial, the gap was eliminated but results were inconclusive since it was not known whether the $\mathrm{KCl}, \mathrm{LiCl}, \mathrm{K}_{2} \mathrm{CO}_{3}$ and $\mathrm{Li}_{3} \mathrm{CO}_{3}$ melted and wicked into the elentrnlyte at the same ratc. Final. $1 y$, the gap was bridged by dropping a piece of zirconia across the gap after all the electrolyte had melted. Four chloride concentrations (23, 50, 78 and 92 anion percent chloride) and two fluoride. (23 and 44 anion percent fluoride) concentrations were tested. The potential difference using a continuous matrix containing halide-free electrolyte was measured to be $2.5 \mathrm{mV}$. Results are plotted in Figure 3-5. All but one potential difference shown are peak values. Peak occurred briefly (15 minutes to 30 minutes) after the gap was closed. After that, polarization slowly aropped to zero, approximately overnight. Also shown in Figure 3-5 is a point taken from'a study on the effects of sulfur, and a line representing the Nernst equation which accounts for the ratio of carbonate ion activities between the two elertrones.

The cause for the data differing from the Nernst equation is not known. Possible reasons are that a liquid junction potential effect is significant, that an unknown reaction is taking place, that a complex is forming (such as $\mathrm{K}_{2} \mathrm{CO}_{3}-\mathrm{KF}$ ), or that the carbonate ion is dissociating to $\mathrm{CO}_{2}$, as is suggested by Kruglov, et al. [5]. The data seem to follow the Nernst equation for anion fractions of halide less than 0.23 . 
○

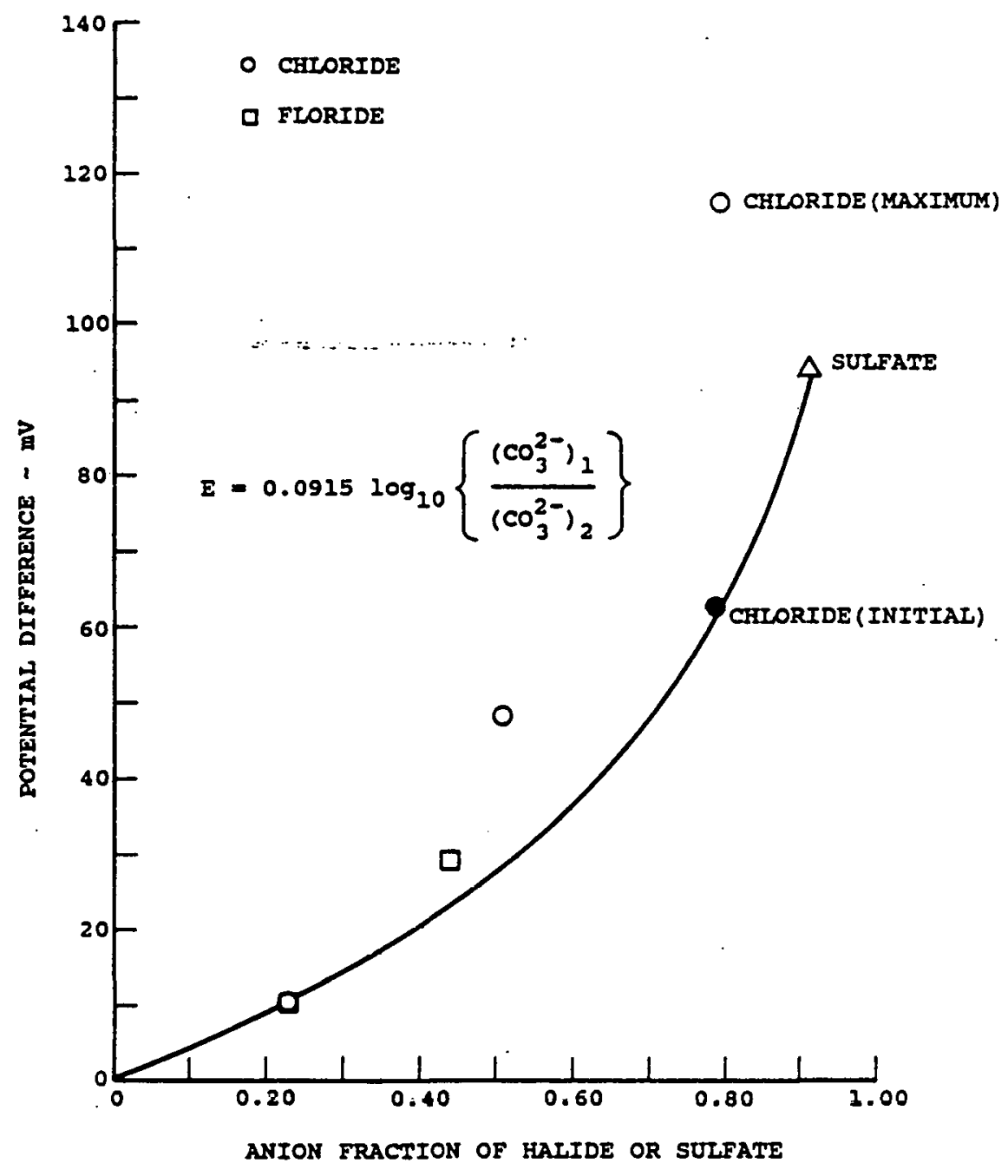

Figure 3-5. Concentration Difference Test Results Vs. Nernst Equation

All previous half-cell performance tests were conducted using tile matrices that were about $70 \mathrm{mils}$ thick [21]. The present full cells used tape matrices that are $18 \mathrm{mils}$ thick. It was desirable to use the same components from present day full cells in the half cells. Therefore, prior to performance testing in the presence of halides, several tests were performed to demonstrate reproducible results with tape matrices. 
Shown in Table 3-2 is a brief description of each of the twelve half-cell tests to measure performance. Although twelve tests were conducted, five tests were used in rig development. Besides two baseline tests, only those tests yielding results on halide effects will be dealt with in depth.

Table 3-2, Half-Cell Test Summary

Test

\section{Objective}

Operating Time (Hours)

Cathode Test \#1 Repeat prior half-cell data. Cell

failed when RE* broke through tape.

Cathode Test \#2 Repeat Test \#1 only using $\mathrm{CeO}_{2}$ block

to prevent RE breakthrough.

Cathode Test \#3 Use $\mathrm{LiAlO}_{2}$ powder to promote better contact between WE and matrix.

Cathode Test \#4 Test a new half-cell rig. To be compared 90 to Test \#3.

Cathode Test \#5 Bind tape and WE together by softening tape 308 with isopropanol.

Cathode Test \#6 Test cell with 3.1 anion percent chloride in the electrolyte.

Cathode Test \#7 Bind tape and WE together by hot pressing 506 WE into tape. No halide.

Cathode Test \#8 Test cell with 23 anion percent chloride in the electrolyte. Used $\mathrm{NiO} \mathrm{CE}$.

Cathode Test \#9 Test cell with 23 anion percent fluoride in the electrolyte. Used NiO CE.

Anode Test \# 1 Baseline anode test. Used Ni CE.

Anode Test \#2

Test cell with 23 anion percent chloride in the electrolyte. Used $\mathrm{Ni} C E$.

Anode Test \#3 Test cell with 23 anion percent fluoride in the electrolyte. Used $\mathrm{Ni} \mathrm{CE}$.

${ }^{*} \mathrm{RE}=$ Reference electrode; $\mathrm{WE}=$ working electrode; $\mathrm{CE}=$ counter electrode 
Cathode Test \#3 - This test ran without halide in the electrolyte in order to reproduce prior data, only using a tape matrix instead of the tile matrices used previously. Since erratic performance changes in Cathode Test \#2 were attributed to a loss of contact between the cathode and tape, in this test $173 \mathrm{mg}$ of fine $\mathrm{LiAlO}_{2}$ powder was placed between the electrode and the tape to maintain electrolyte contact. Electrolyte was removed from the wick area using a piece of porous $\mathrm{CeO}_{2}$ attached to an alumina rod. The $\mathrm{CeO}_{2}$ has a finer pore structure than the matrix, and electrolyte preferentially wicks into the $\mathrm{CeO}_{2}$ from the matrix. The $\mathrm{CeO}_{2}$ was allowed to remain in contact witih the matrix for about half of an hour, after which the $\mathrm{CeO}_{2}$ was removed from the cell, cooled and weighed. At each electrolyte content in the rig, open-circuit potential, the iR-free cathode overpotential, the cell iR at $160 \mathrm{~mA} / \mathrm{cm}^{2}$, and cell temperature were measured. The data did not repeat the Cathode Test \#2 data and the cell iR was high ( 120 to $171 \mathrm{mV}$ at $\left.160 \mathrm{~mA} / \mathrm{cm}^{2}\right)$, but the overpotential data compared favorably with previous data. Figure 3-6 shows the data from Test \#3. The mass of electrolyte was converted to percent fill, assuming that the added $\mathrm{LiAlO}_{2}$ powder had properties similar to the tape matrix (same pore spectra, same void volume) and that it had a bulk density of $1.09 \mathrm{~g} / \mathrm{cc}$.

The experimental data obtained in Test \#3 were obtained using an oxidant gas consisting of $0.67 \mathrm{~atm} \mathrm{CO}_{2}$ and $0.33 \mathrm{~atm} \mathrm{O}_{2}$. In order to compare the data with that obtained previously with tile matrices and other tests run with halides, the cathode Test \#3 data were corrected to the test plan oxidant by multiplying the overpotential under the $1: 2 \mathrm{O}_{2}: \mathrm{CO}_{2}$ oxidant by 1.2. The value of 1.2 was determined by comparing old data under the test plan oxidant to old data under the $1: 2 \quad \mathrm{O}_{2}: \mathrm{CO}_{2}$ oxidant. The results are shown in Figure 3-7. For the old $44 \mathrm{mil}$ cathode the correction was $1.12 \pm$ 0.01 at fills less than 22 percent, and for the old $33 \mathrm{mil}$ cathode the correction was $1.33 \pm 0.02$ at fills less than 31 percent. A weighted average of these two values gives a correction factor of 1.2 for a 40 mil cathode. The present halide-free electrolyte data compares favorably with the old data. 

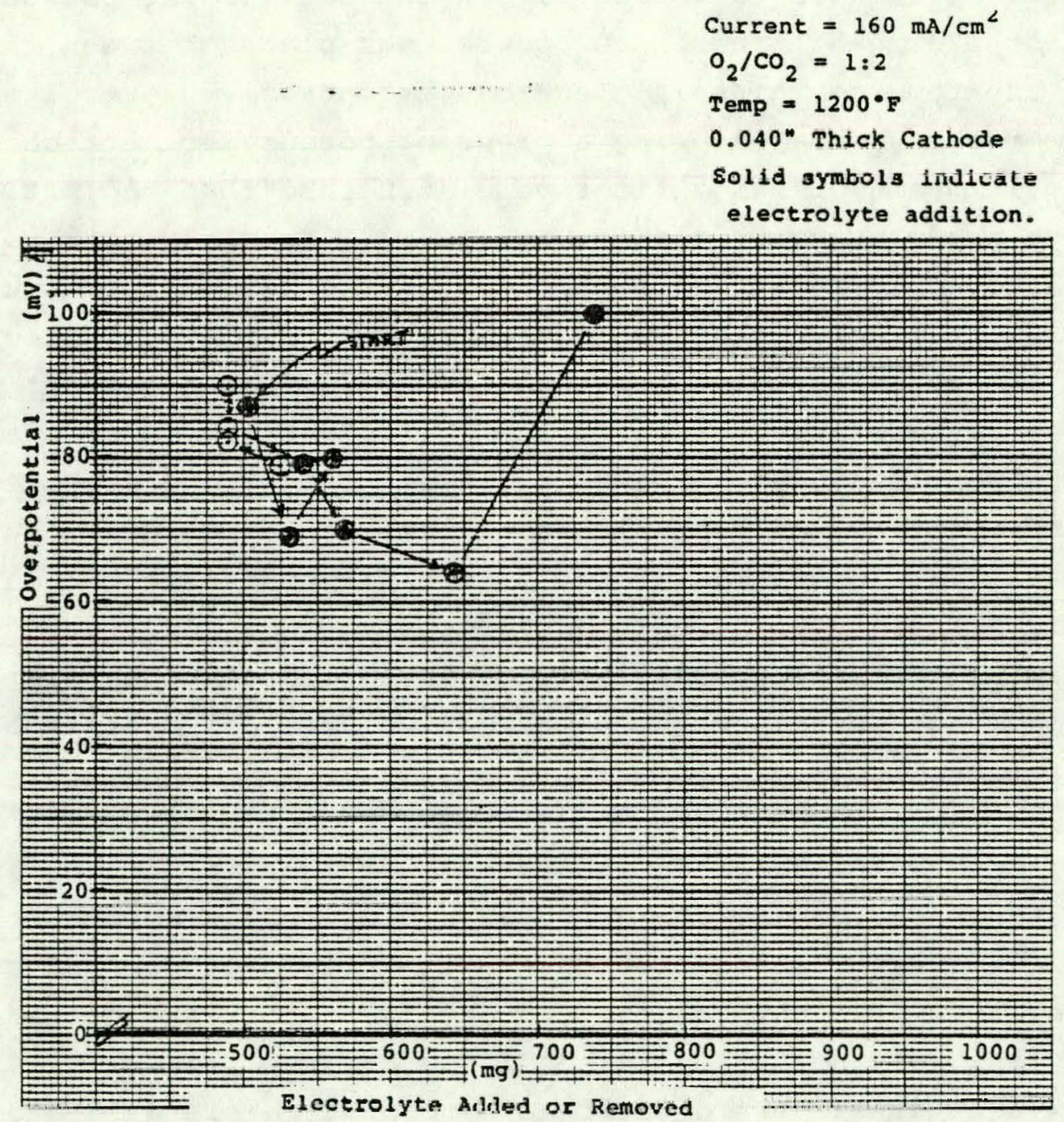

Figure 3-6. Half-Cell Cathode Test \#3 


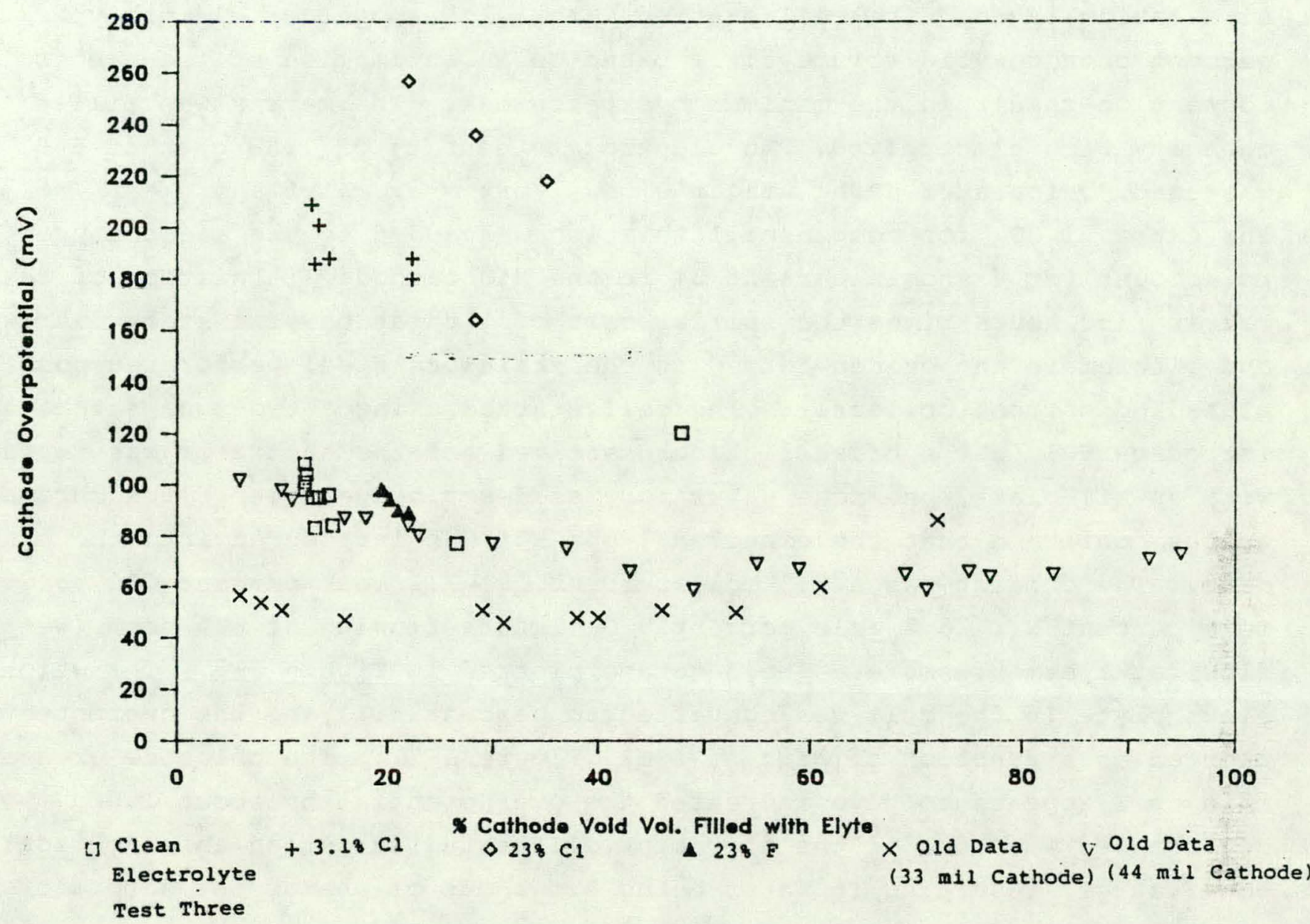

Figure 3-7. Effect of Halide on Cathode Half-Cell

Cathode Test \#6 - The purpose of this test was to determine the effect of a low chloride concentration in the electrolyte. To maintain electrolyte contact between the cathode and the tape, the tapes were softened with isopropanal and pressed onto the cathode prior to cell assembly. The cell was then heated to $704^{\circ} \mathrm{C}$ to burn impurities out of the tape. The cell temperature was reduced to $649^{\circ} \mathrm{C}$ and 72 mole percent $\mathrm{Li}_{2} \mathrm{CO}_{3}, 28$ mole percent $\mathrm{K}_{2} \mathrm{CO}_{3}$ electrolyte containing extra $\mathrm{Li}_{2} \mathrm{CO}_{3}$ for component lithiation was added to the cell. The electrolyte contained 3.1 anion percent chloride, as described in the test plan, while maintaining a $72: 28$ 
Ii:K cation ratio. The cell started with a low amount of electrolyte (22 percent cathode void volume fill) based on an estimation of the electrolyte content to result in the minimum overpotential. The matrix was filled to capacity with electrolyte. An electrolyte density of $1.88 \mathrm{~g} / \mathrm{cc}$ at $649^{\circ} \mathrm{C}$ was used, calculated using Amagat's Law ( $\bar{V} m i x=\sum_{i=1}^{n} x i \bar{V} i$ and $\left.\rho=1 / \bar{V} m i x\right)$. The extra $\mathrm{Li}_{2} \mathrm{CO}_{3}$ for component lithiation was added to the electrolyte to account for 4 atomic percent $\mathrm{Li}$ in the NiO cathode, lithiation of the matrix ( 350 hours times the initial rate of lithiation of a stack matrix), and lithium in the oxides formed in the stainless steel perforated push plate and current collector. The cell started using a two-zonc saturator to introduce $\mathrm{HCl}$, but a brass fitting dissolved and the saturator was replaced with an all-glass, one-zone saturator, as described earlier. Ion chromatography confirmed that the expected 1 ppm $\mathrm{HCl}$ was introduced into the oxidant. The oxidant was a 9.5 mole percent $\mathrm{O}_{2}, 7.2$ mole percent $\mathrm{CO}_{2}, 64.6$ mole percent $\mathrm{N}_{2}, 18.7$ mole percent $\mathrm{H}_{2} \mathrm{O}$ mixture flowing at $600 \mathrm{sccm}$ (wet flow) at 1 atm pressure. The data are plotted in Figure 3-8. The weight of electrolyte in the cell was converted to percent fill and the overpotential plotted as a function of percent fill (Figure 3-7). The chloride present in this cell appears to have increased the overpotential by about $100 \mathrm{mV}$. The cell failed when one of the flow controllers failed during an electrical power surge, resulting in water being blown out of one of the saturators and into the cell, cracking the matrix. 

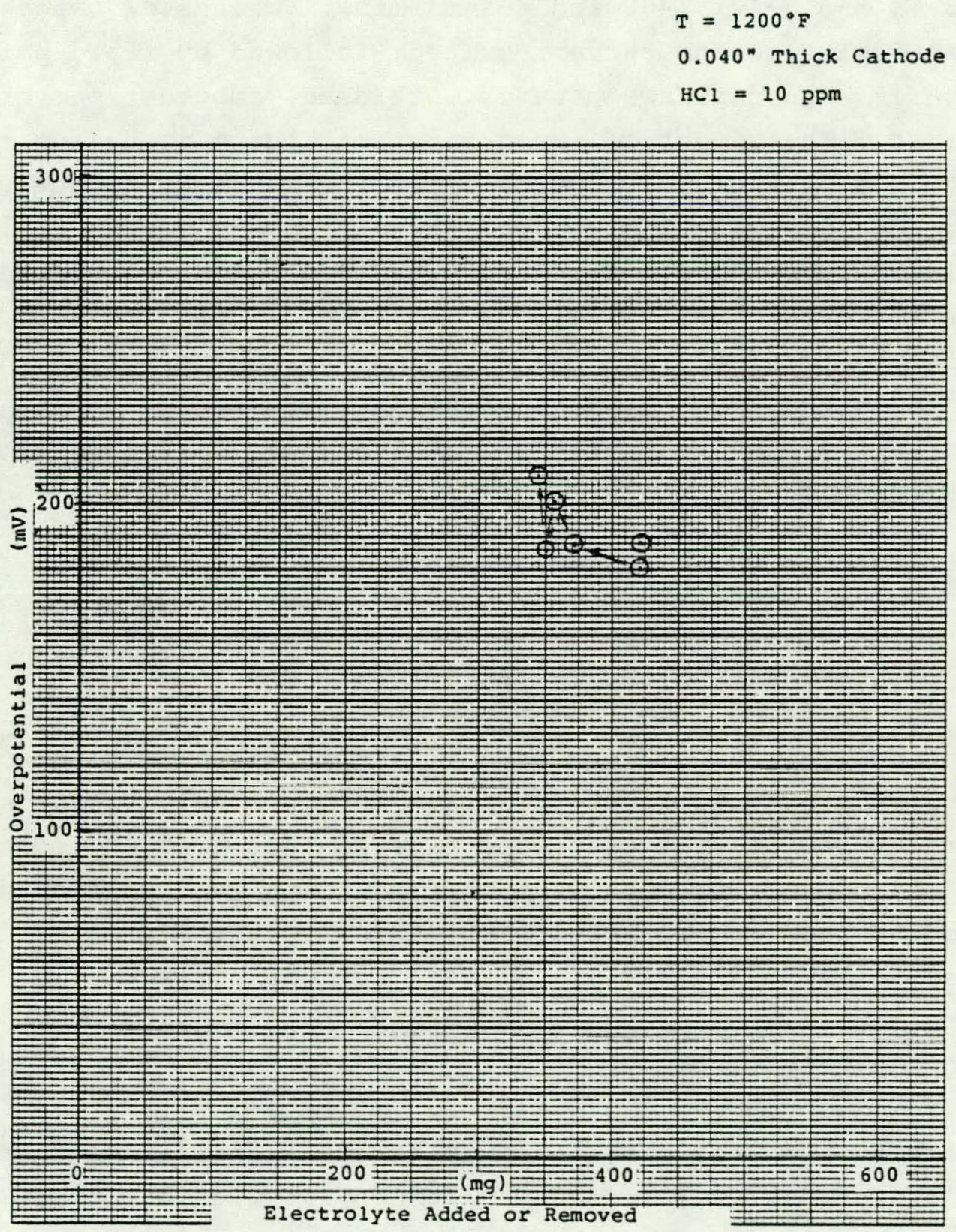

Figure 3-8. Half-Cell Cathode Test \#6 
Several current versus potential sweeps were taken, two at a slow sweep rate (Figures $3-9$ and $3-10)(25 \mathrm{~mA} / \mathrm{min}$ ) and two at a fast sweep rate (Figures $3-11$ and $3-12)(400$ and $800 \mathrm{~mA} / \mathrm{min})$. When slow sweep rates were used, a wavy polarization curve resulted, followed by rapid polarization changes. When fast sweep rates were used, smoother performance curves were obtained. The effect of sweep rate is thought to be due to halide ion concentration gradients building up among the working, counter, and reference electrodes during the slow sweep rates. Since carbonate ions are produced in the working electrode and consumed in the counter electrode, the halide ion concentration will decrease in the working electrode and increase in the counter electrode with time. Eventually, the halide ion concentration might reach a point where chloride evolution can occur from the counter electrode, resulting in the rapid oscillations in the polarization data.

Cathode Test \#8 - The purpose of this test was to determine the effect of a high chloride concentration in the electrolyte. Because of the fragility of unsupported tape matrix and ponr electrode contact with the matrix in the half-cell rig in contrast to the excellent tape matrix properties seen in fuel cells, Cathode Test \#8 started using some of the start-up procedures used in full cells. To minimize tape cracking and tape separation during the test, the tape was hot pressed between two pieces of cathode at $204^{\circ} \mathrm{C}$ and $100 \mathrm{psi}$ resulting in a configuration similar to the anode confiquration shown in Figure 3-3, with the exception that a sheet of AISI 310 stainless steel current collector was placed between the alumina base plate and the gold screen so that gases could escape from the Nio counter electrode.

After assembly, the cell was heated in a manner similar to that used in a full-cell start-up. The cell was heated to $204^{\circ} \mathrm{C}$ and held at $204^{\circ} \mathrm{C}$ under $\mathrm{O}_{2} / \mathrm{CO}_{2} / \mathrm{N}_{2}$ overnight (or 8 hours minimum) to burn binder out of the tape. The cell was then heated to $470^{\circ} \mathrm{C}$ and the electrolyte added. 
$1208^{\circ} \mathrm{F}$

$25 \mathrm{~mA} / \mathrm{min}$

$105^{\circ} \mathrm{F}$ HCl sat

$139^{\circ} \mathrm{F} \quad \mathrm{H}_{2} \mathrm{O}$ sat

Cathode: $10 \mathrm{ppm} \mathrm{HCl}$

minimum

electrolyte

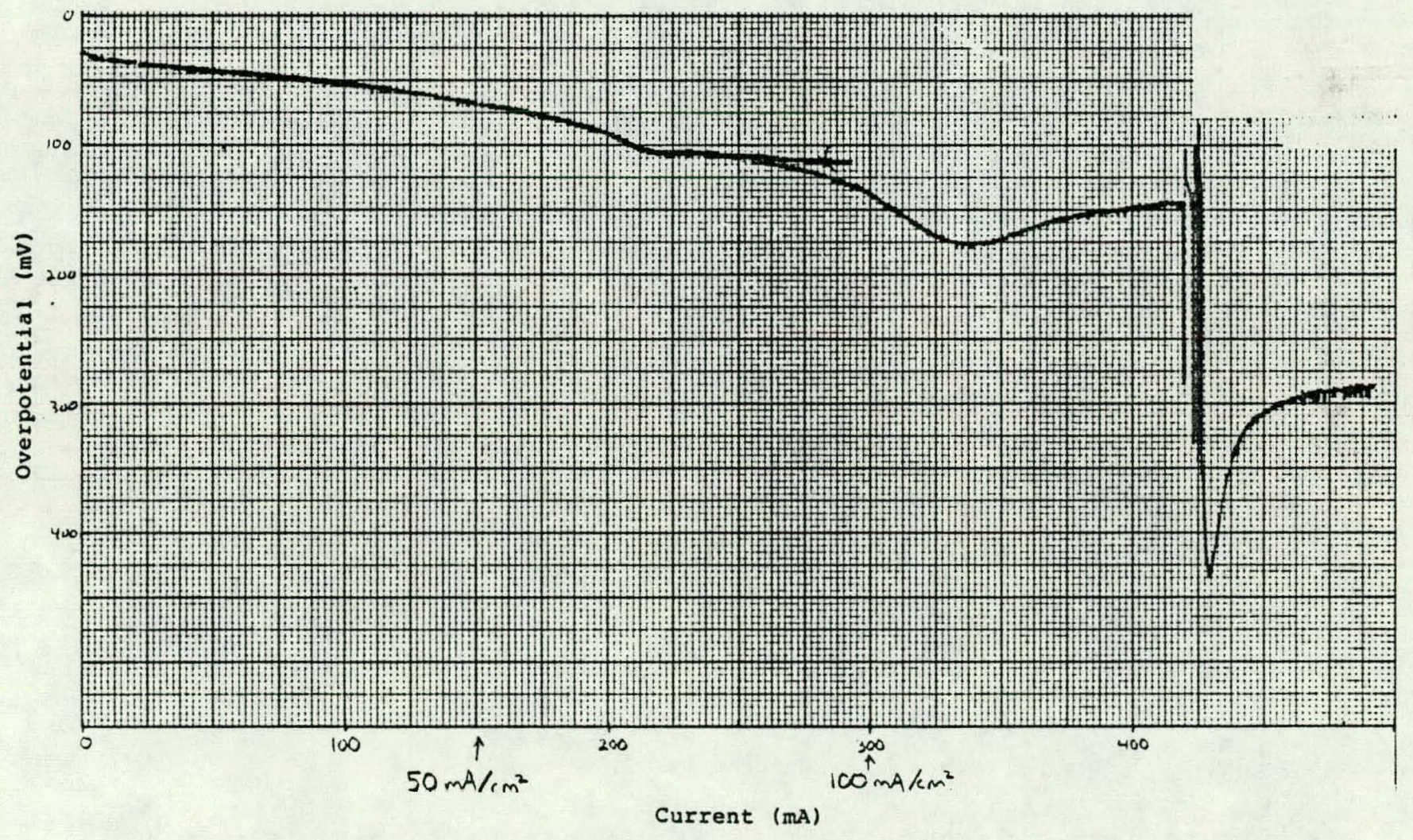

Figure 3-9. Cathode Test \#6 slow Sweep Performance Curve \#1 


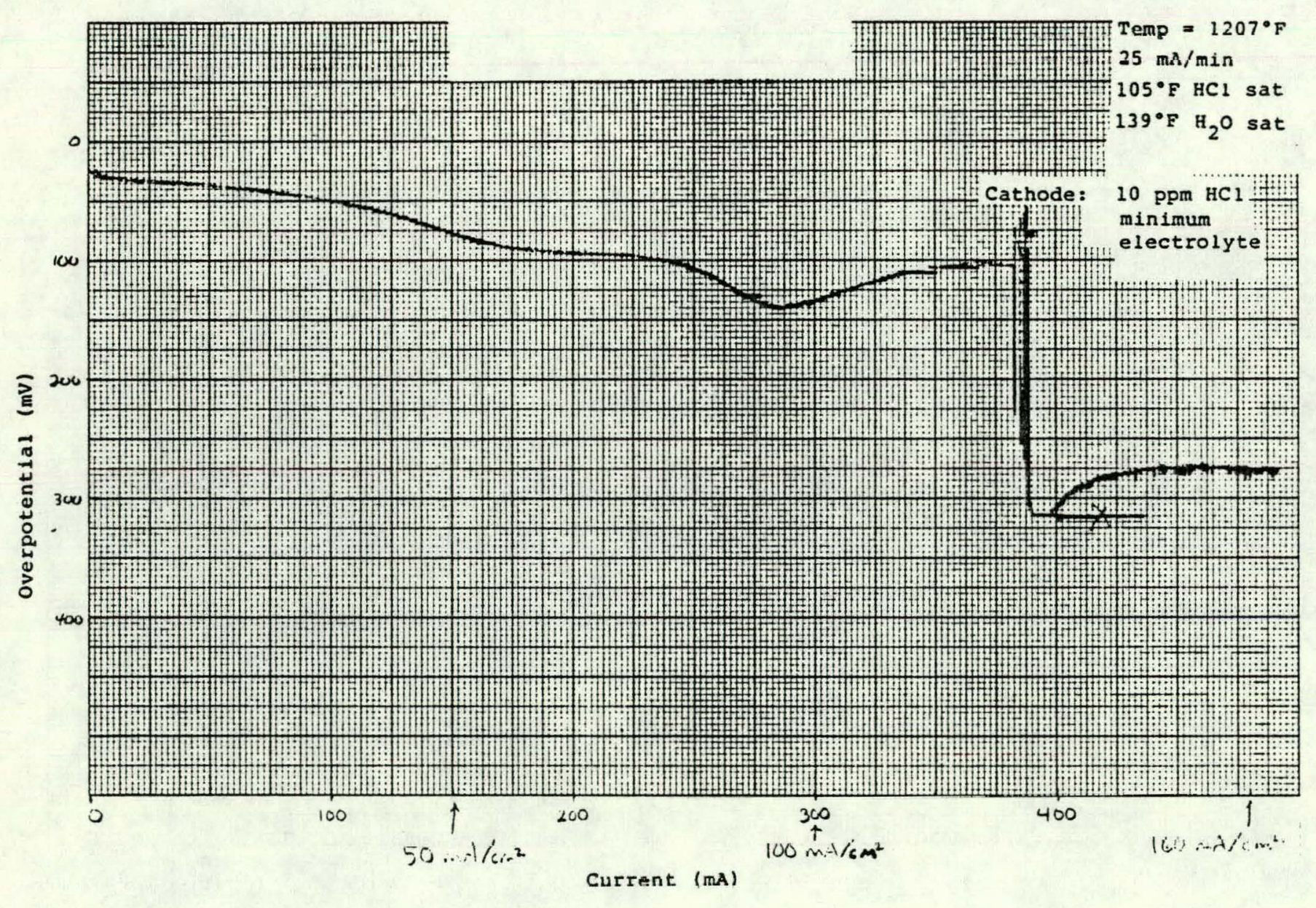

Figure 3-10. Cathode Test \#6 Slow Sweep Performance Curve \#2 

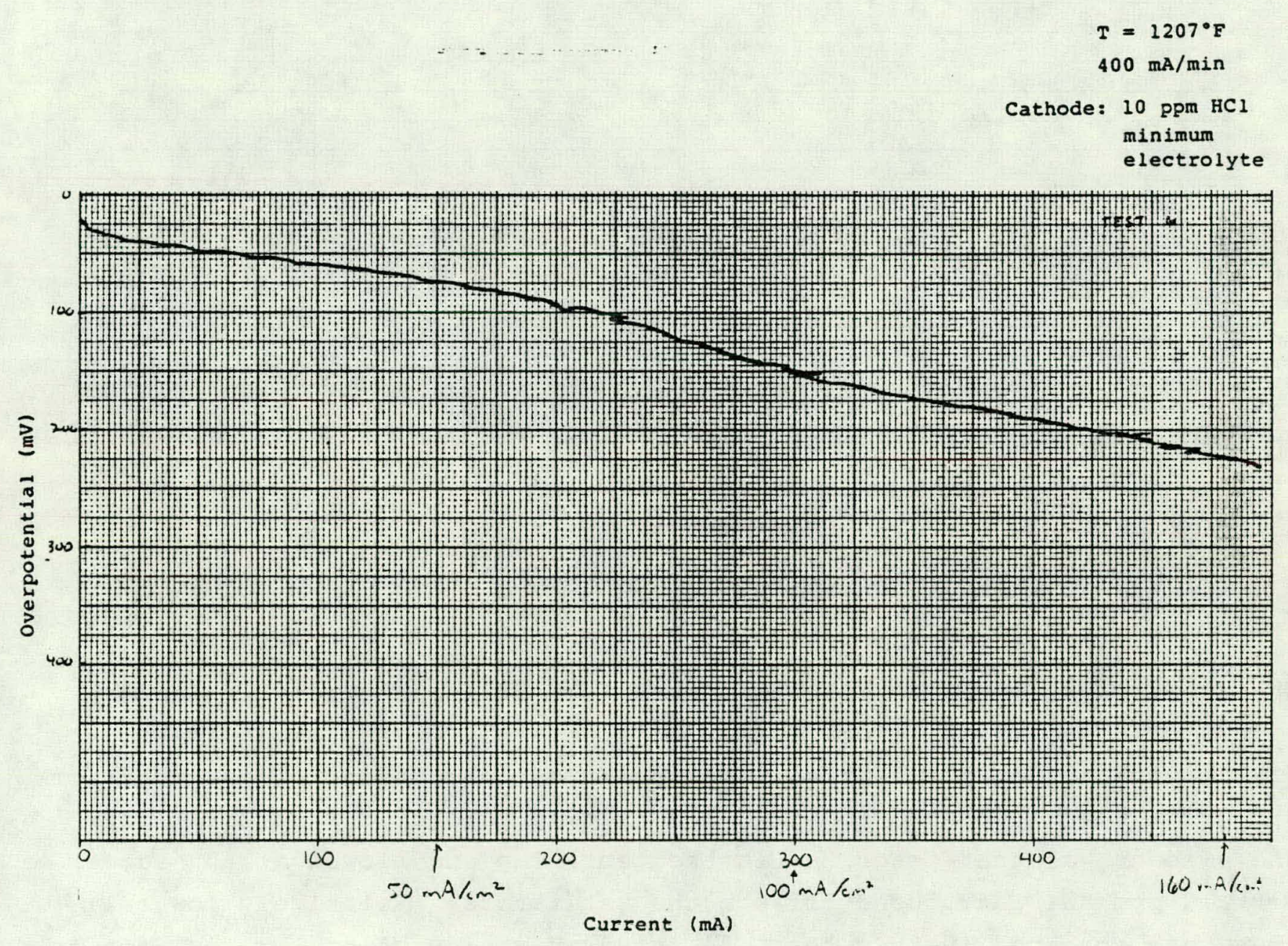

Figure 3-11. Cathode Test \#6 Fast Sweep Performance Curve \#1 
$T=1207^{\circ} \mathrm{F}$

$800 \mathrm{~mA} / \mathrm{min}$

Cathode: 10 ppm HCl minimum electrolyte

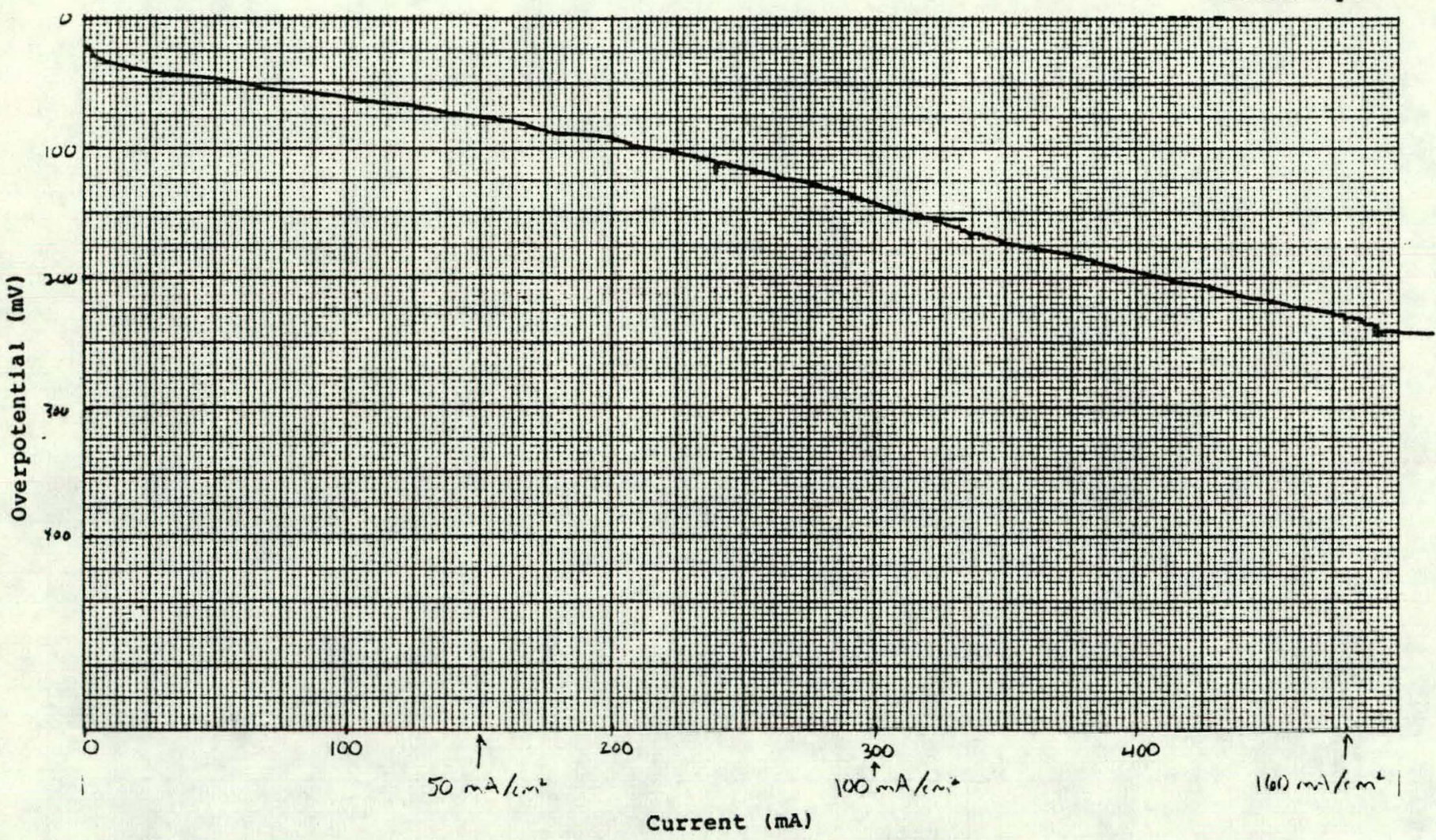

Figure 3-12. Cathode Test \#6 Fast Sweep Performance Curve \#2

The electrolyte added in this test contained 23 anion percent chloride, maintaining a 72:28 $\mathrm{Li}: \mathrm{K}$ cation ratio. Extra $\mathrm{Li}_{2} \mathrm{CO}_{3}$ was added in similar amounts to Cathode Test \#6. The cell was held at $470^{\circ} \mathrm{C}$ overnight (or 8 hours minimum), heated to $650^{\circ} \mathrm{C}$ and allowed to equilibrate for a day. The oxidant was that described in the test plan and flowed at $600 \mathrm{sccm}$ with $10 \mathrm{ppm} \mathrm{HCl}$ introduced through the saturators. Relatively low cell $i R^{\prime} s$ were achieved in this test $\left(44\right.$ to $90 \mathrm{mV}$ at $160 \mathrm{~mA} / \mathrm{cm}^{2}$ ). The data is shown in Figure $3-13$ and the overpotential is plotted as a function of percent fill in Figure 3-7. Overpotential as a function of current was measured twice and is shown in Figures 3-14 and 3-15. 
$I=160 \mathrm{~mA} / \mathrm{cm}^{2}$

$100 \mathrm{ppm} \mathrm{HCl}$

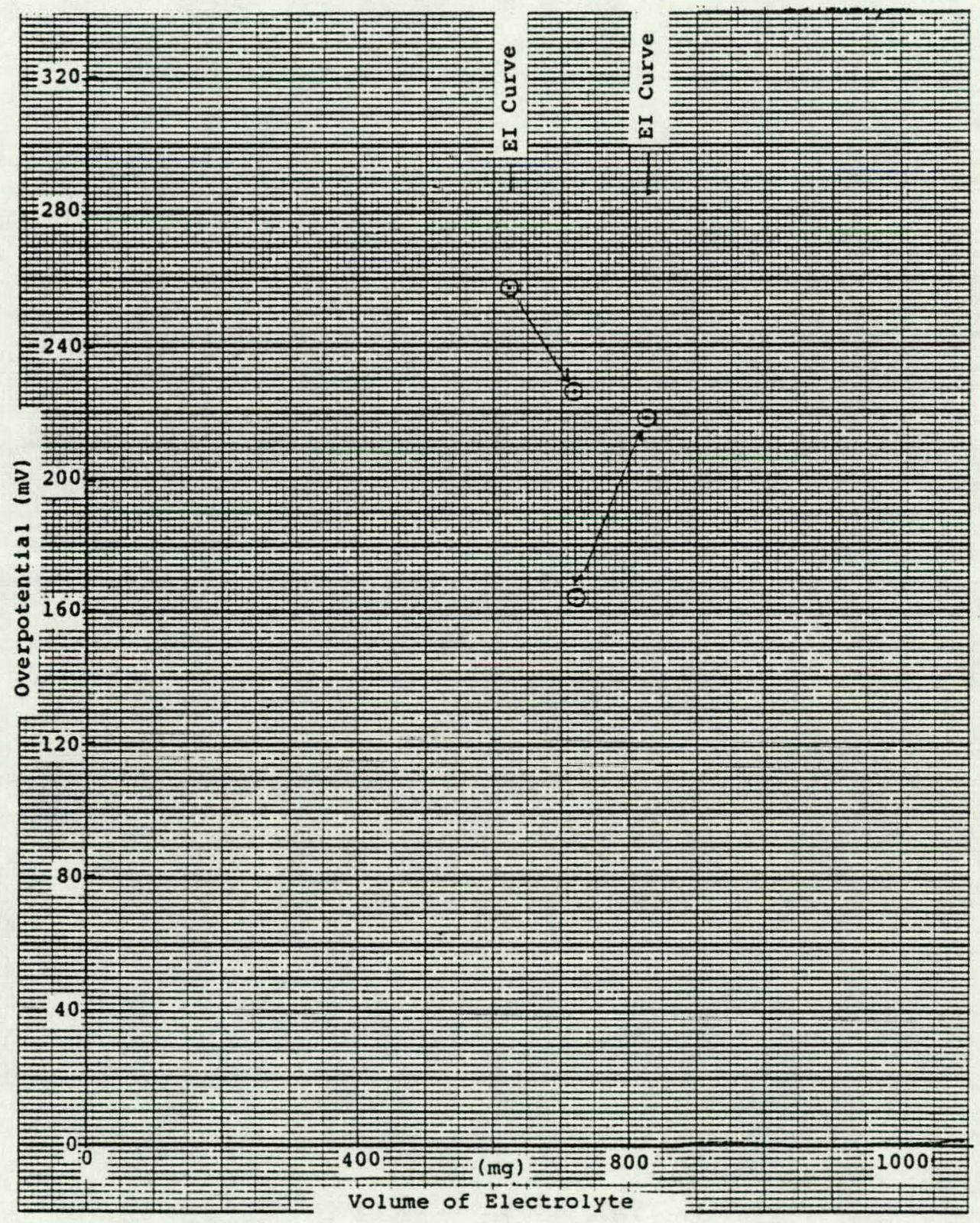

Figure 3-13. Half-Cel1 Cathode Test \#8 


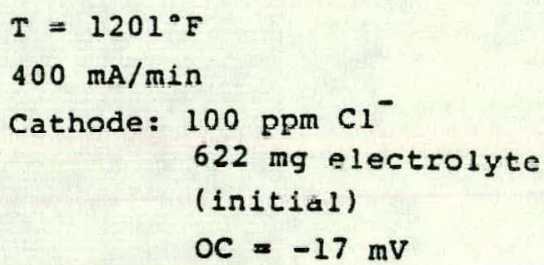

○ 15:10 -1:1 1.:

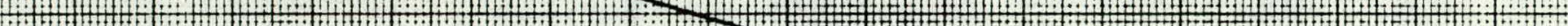
(1) 10101010 1: 1.! 15: 16! D.

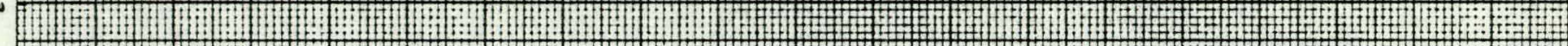

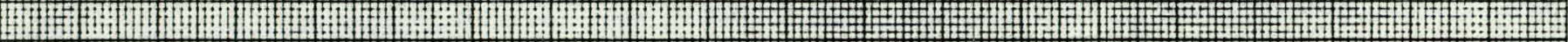

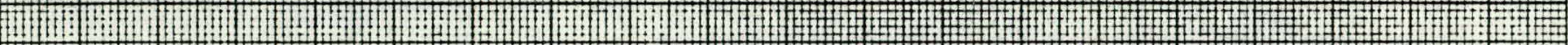

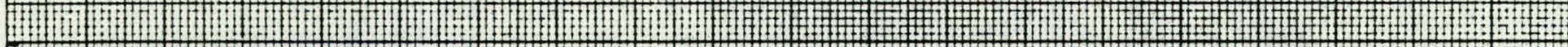
[1: 1.1 11: 15 (10 10 (1) L.1.

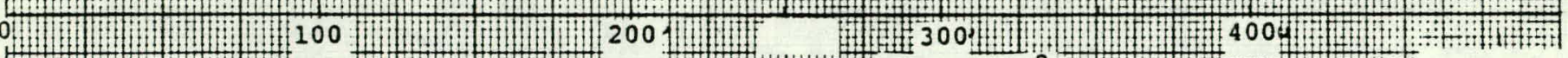

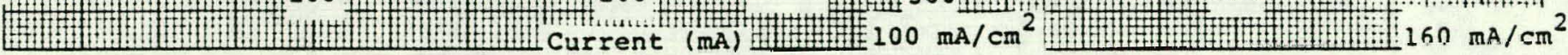

Figure 3-14. Cathode Test \#8 Fast Sweep Performance Curve \#1 
Cathode Test \#9 - This test was similar to Cathode Test \#8, except that the electrolyte contained 23 anion percent fluoride instead of 23 anion percent chloride. An electrolyte density of $1.91 \mathrm{~g} / \mathrm{Cc}$ at $650^{\circ} \mathrm{C}$ was used. A saturator to introduce fluoride was not used; it had been calculated that the vapor pressures of $\mathrm{LiF}$ and $\mathrm{KF}$ were so low that fluoride loss would be small and a fluoride make-up was unnecessary (fluoride content was calculated to drop from 23 anion percent fluoride to 21.4 anion percent fluoride after 350 hours of operation). The test plan oxidant flowed at $600 \mathrm{sccm}$ (wet) with no halide. The cell was assembled in the same manner as Cathode Test \#8. The data are shown in Figure 3-16 and the electrolyte weight was converted to percent fill in Figure 3-7. Note that high concentrations of fluoride do not seem to adversely affect the cathode. Several overpotential vs. current curves were taken (Figures 3-17 to 3-24). Figures $3-17$ and $3-18$ show repeatability at the first point in Figure 3-16. Figures 3-19 and 3-20 are repeatable, even though the curve in Figure 3-19 was taken at a fast sweep rate $(400 \mathrm{~mA} / \mathrm{min})$ and the curve in Figure $3-20$ was taken at a slow sweep rate $(25 \mathrm{~mA} / \mathrm{min})$. The irregularities seen in the Cathode Test \#6 with chloride and slow sweeps are not present in this test. Flgure 3-21 was taken when the cell contained $643 \mathrm{mg}$ of electrolyte. Fiqures 3-22 to 3-24 show repeatability at the last point in Figure 3-16. There is very little difference between any of these sweep curves. Figure 3-25 shows the results of a current step test. The electrode was held at $160 \mathrm{~mA} / \mathrm{cm}^{2}$ for 5 minutes, resulting in $91 \mathrm{mV}$ overpotential. The current was then interrupted and the potential was recorded on a strip chart recorder. The curve shows a rapid drop in potential until about $12 \mathrm{mV}$ is reached, after which the potential drops to zero in about 2 minutes, 30 seconds. This curve suggests that a diffusion process is responsible for the slow drop in potential below $12 \mathrm{mV}$. The working elertrnie, which producos carbonate ions, is free of fluoride, while the reference electrode is surrounded by 23 anion percent fluoride. The $12 \mathrm{mV}$ difference was also found in the concentration gradient polarization study discussed earlier for this anion percent fluoride. 
$0.34 \mathrm{ppm} \mathrm{F}^{-}$

$I=160 \mathrm{~mA} / \mathrm{cm}^{2}$

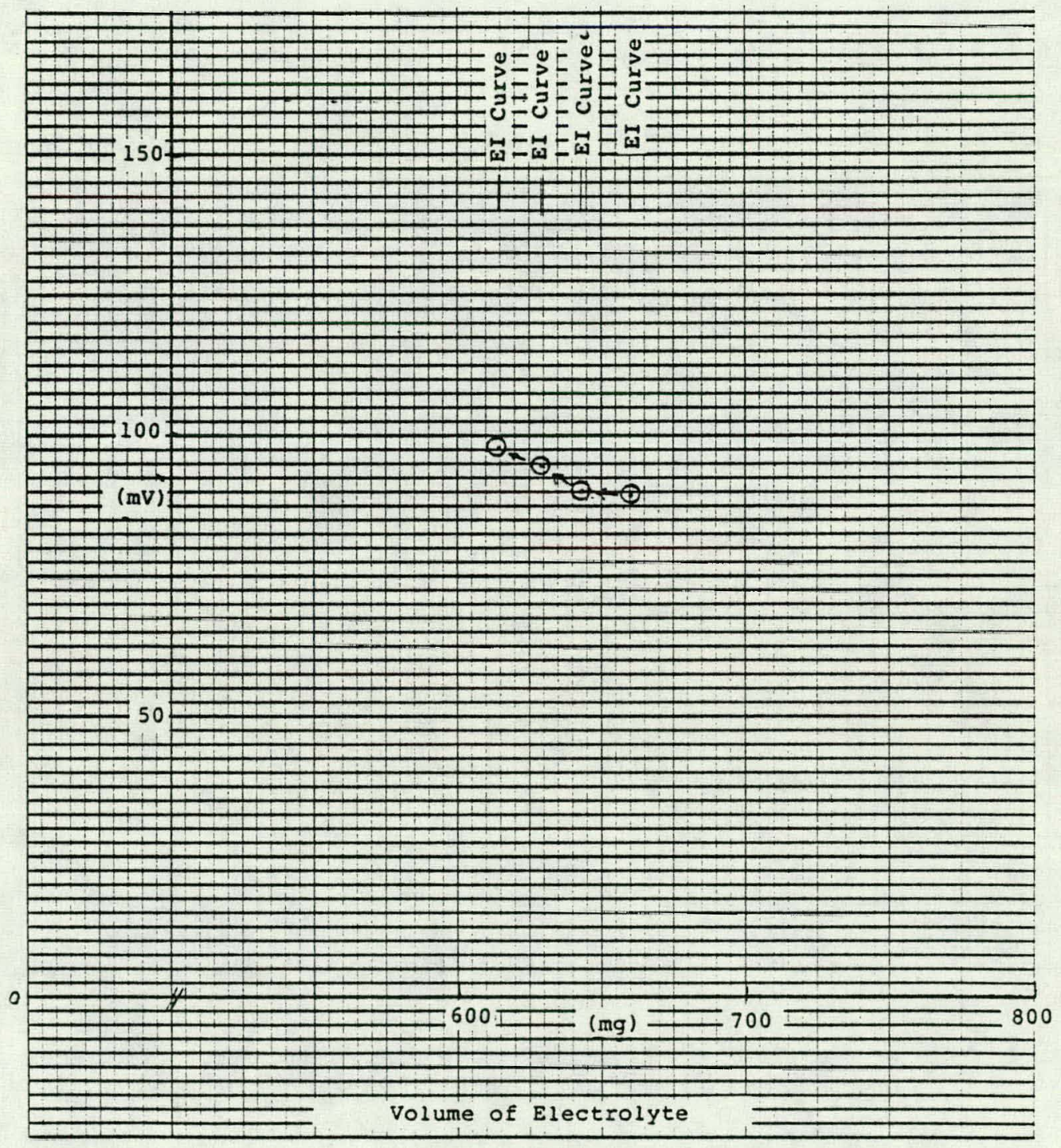

Figure 3-16. Half-Cell Cathode Test \#9 

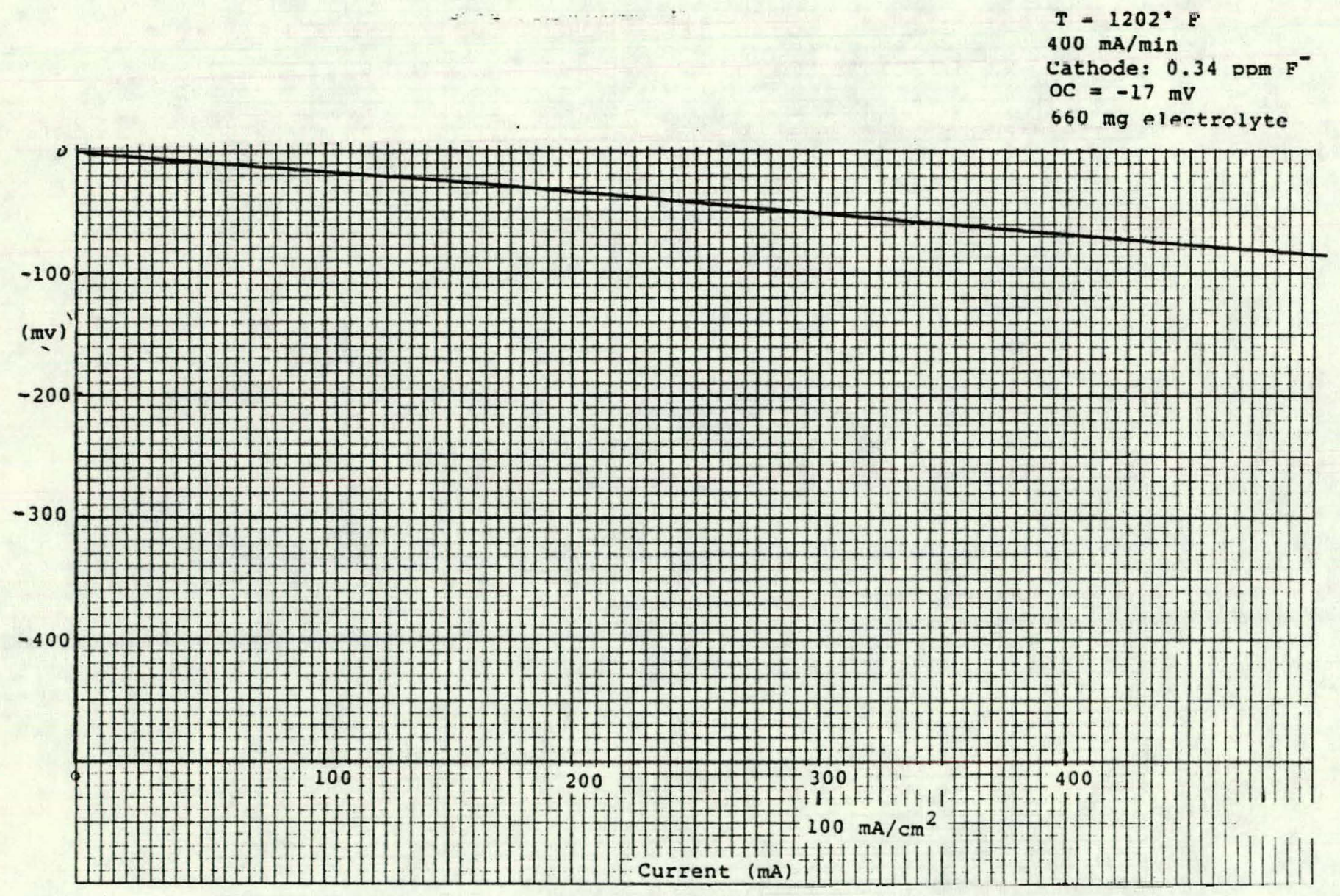

Figure 3-17. Cathode Test \#9 Fast Sweep Performance Curve \#1 With $660 \mathrm{mg}$ of Electrolyte in the Cell. 


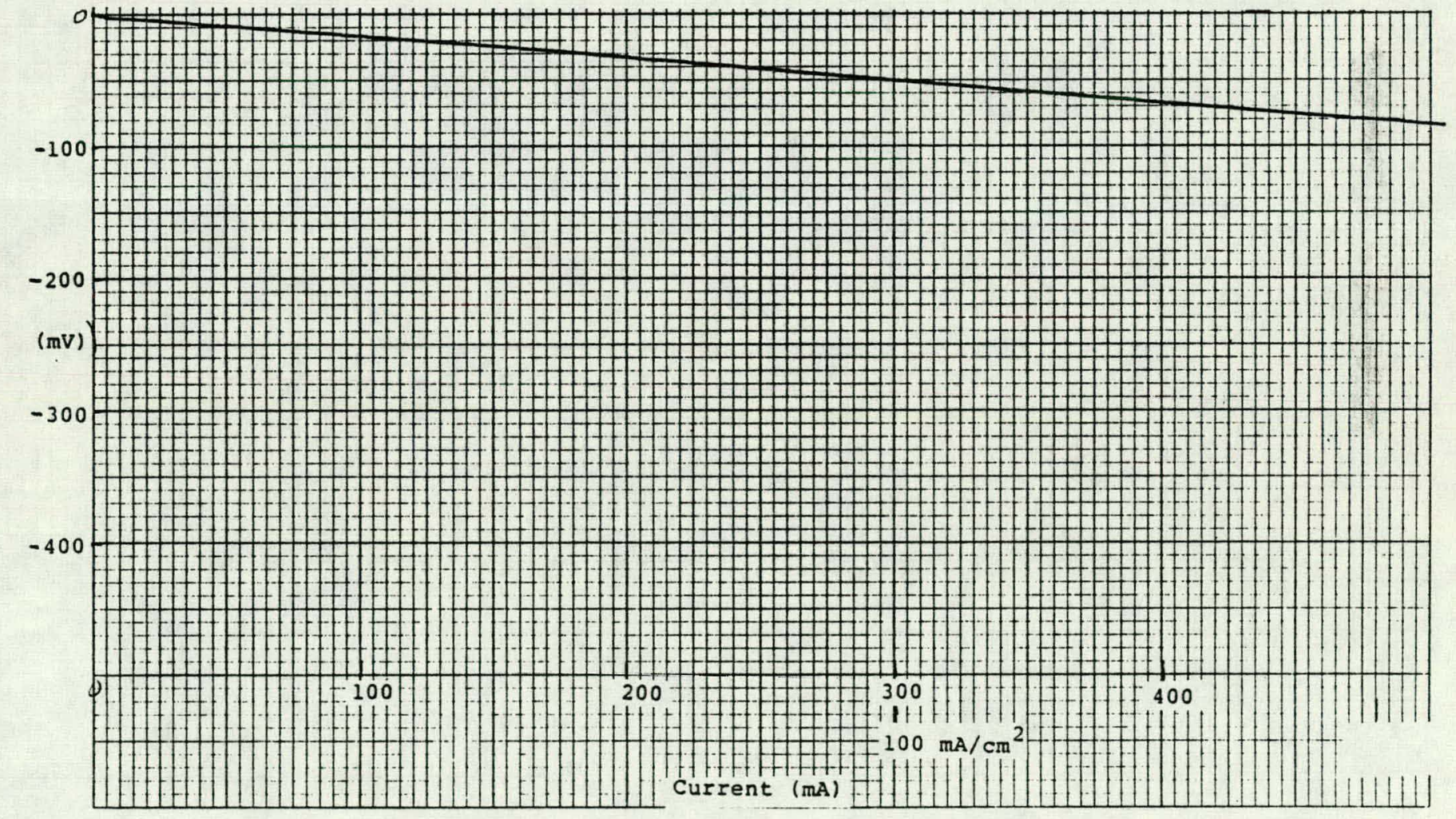

Figure 3-18. Cathode Test \#9 Fast Sweep Performance Curve \#2 With $660 \mathrm{mg}$ of Electrolyte in the Cell 

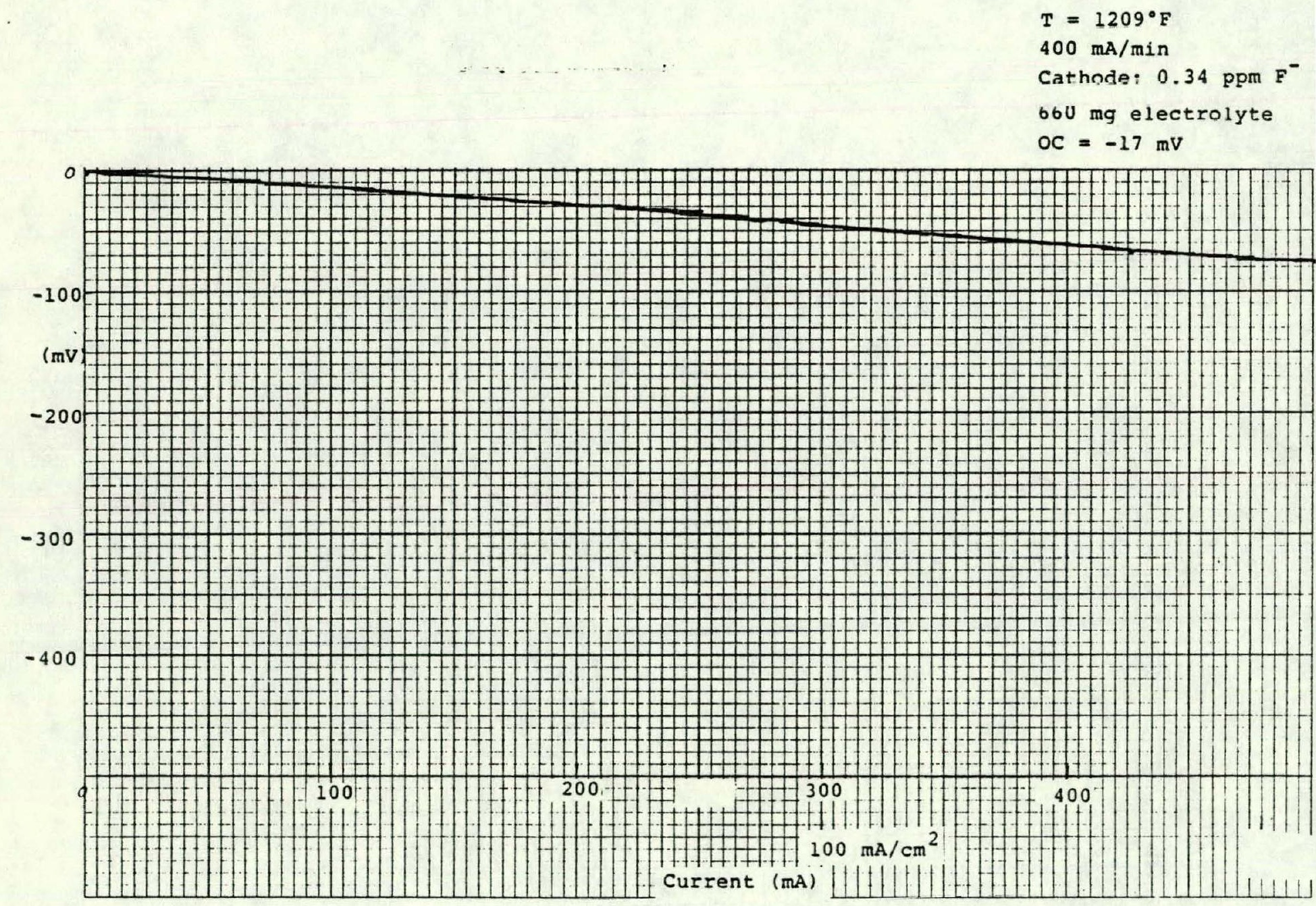

Figure 3-19. Cathode Test \#9 Fast Sweep Performance Curve \#3 With $660 \mathrm{mg}$ of Elcctrolyte in the Cell 

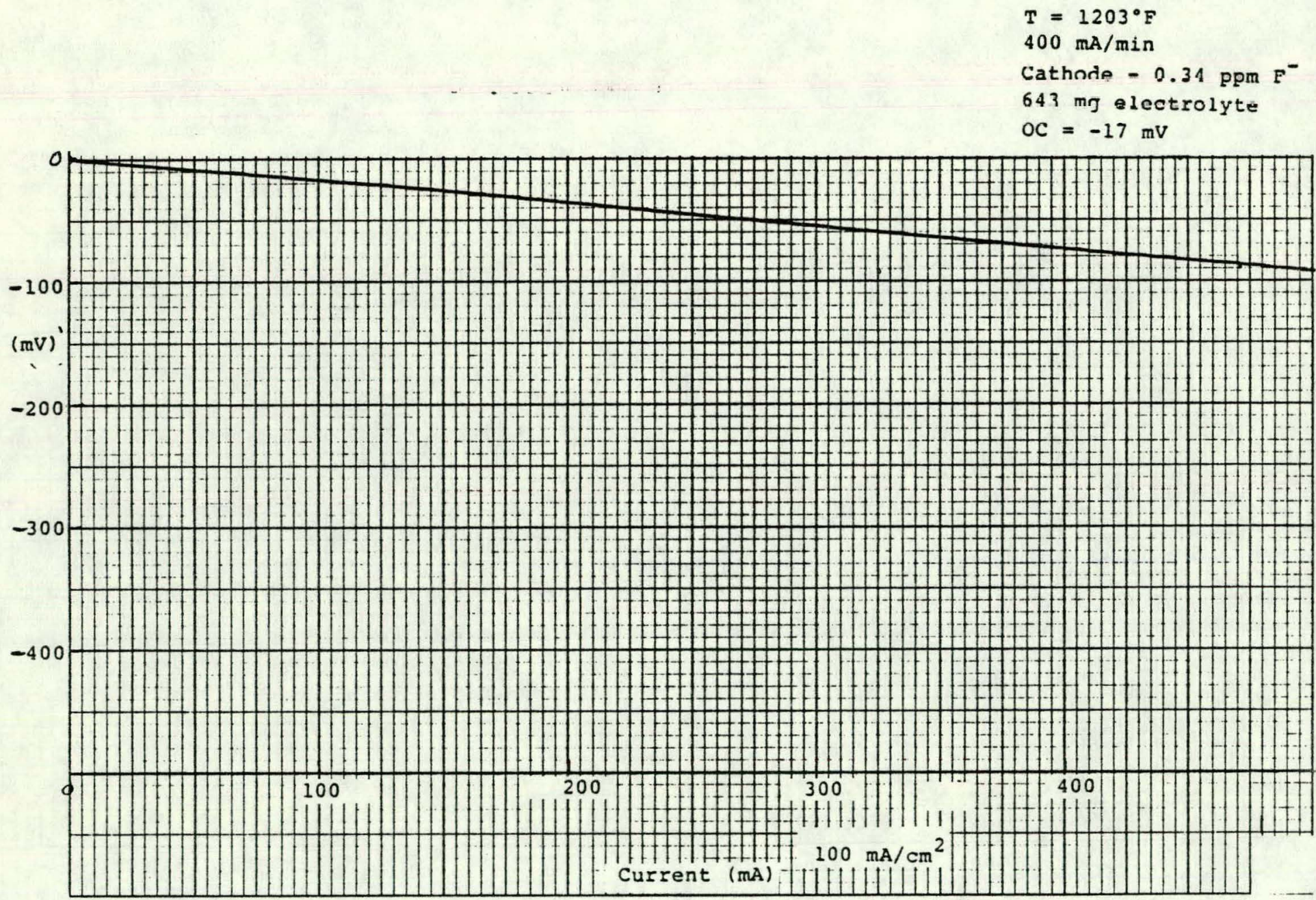

Figure 3-21. Cathode Test \#9 Performance Curve With $643 \mathrm{mg}$ of Electrolyte in the Cell 

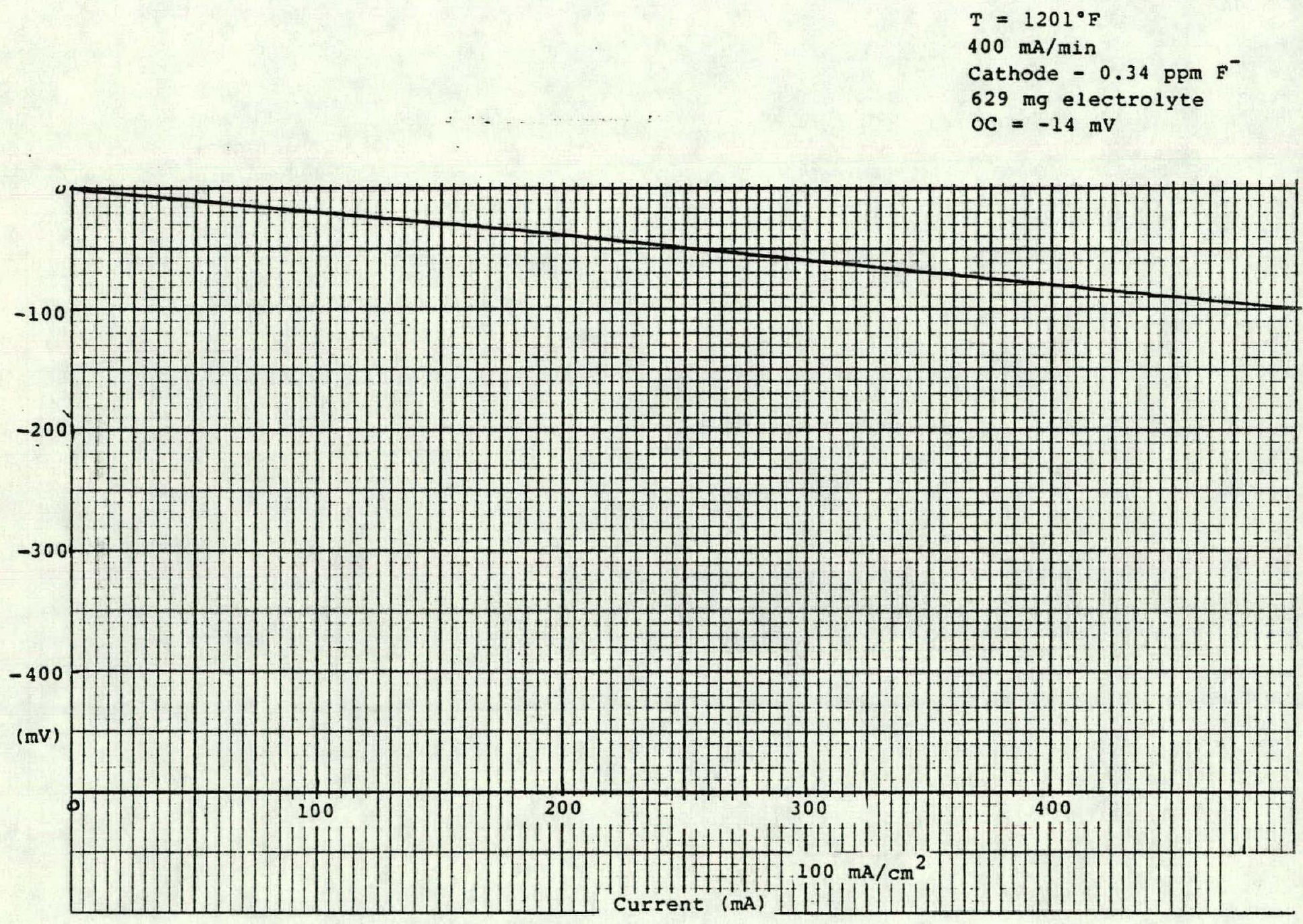

Figure 3-23. Cathode Test \#9 Performance Curve \#2 With $629 \mathrm{mg}$ of Electrolyte in the Cell 

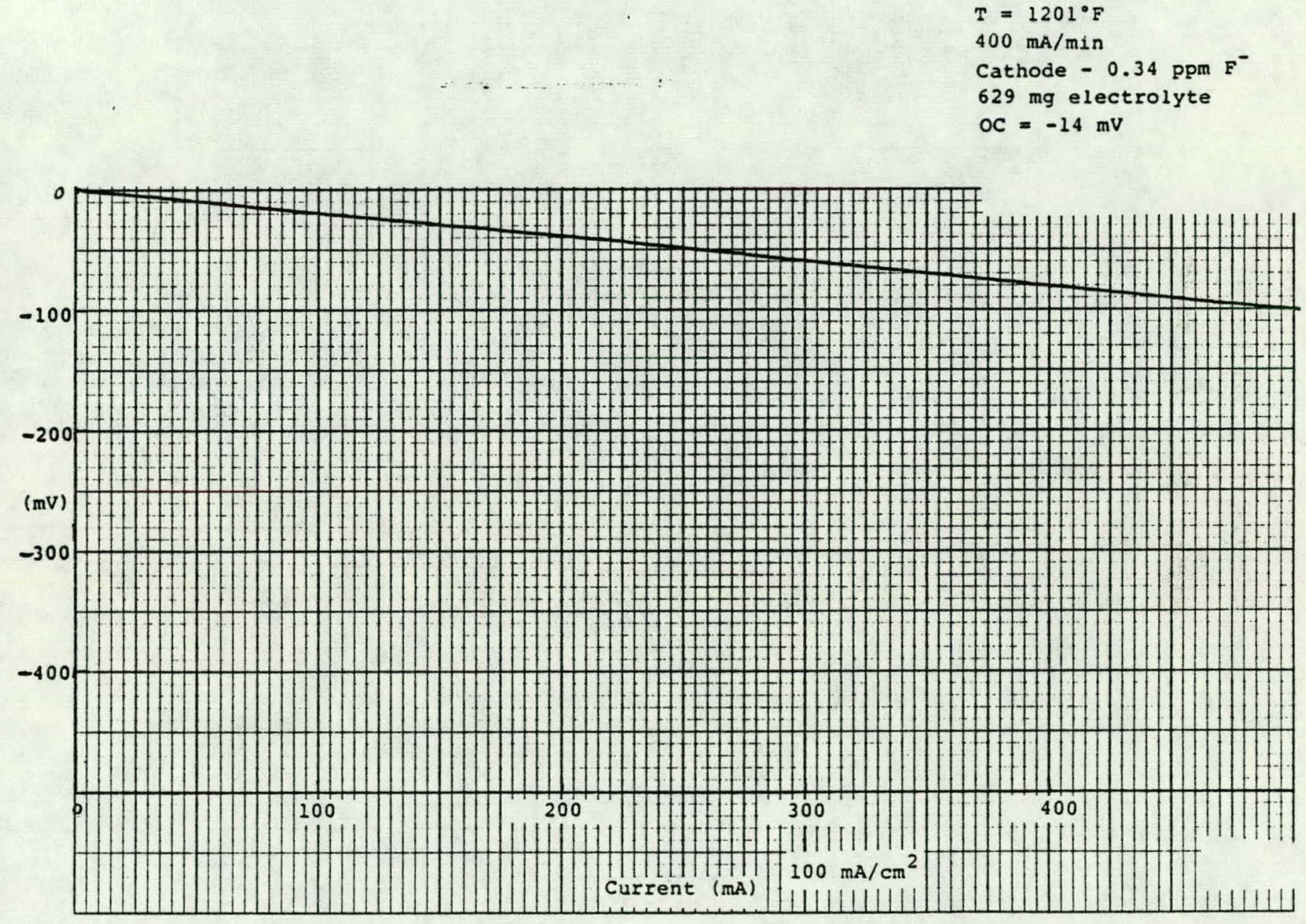

Figure 3-24. Cathode Test \#9 Performance Curve \#3 With $629 \mathrm{mg}$ of Electrolyte in the Cell 


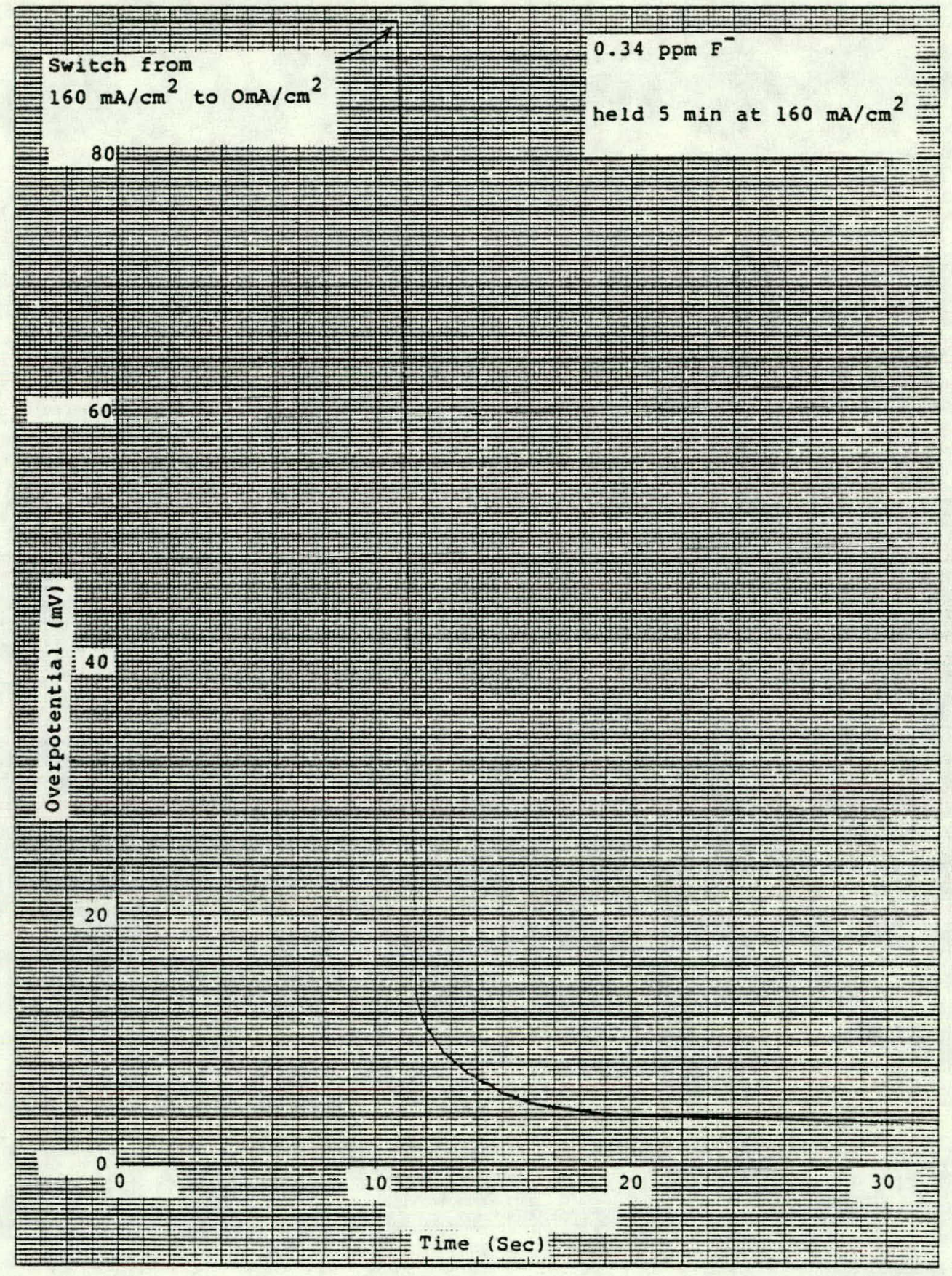

Figure 3-25. Cathode Test \#9 Potential Sweep After Current Step 
Anode Test \#1 - The first anode test was designed to be a baseline test (no halide in the electrolyte) since previous anode half-cell data were scarce. The test configuration shown in Figure 3-3 was used in all three anode half-cell tests. The cells were started in a modified full-cell manner. The cell was first heated to $204^{\circ} \mathrm{C}$ under $1: 2 \mathrm{O}_{2}: \mathrm{CO}_{2}$ for at least 8 hours to burn out the binder in the tapes. The cell was then heated to $470 \mathrm{C}$, electrolyte was added, the cell was purged with $\mathrm{N}_{2}$ and then the cell was put on a 29.4 mole percent $\mathrm{H}_{2}, 5.5$ mole percent $\mathrm{CO}$, 17.5 mole percent $\mathrm{CO}_{2}, 47.6$ mole percent $\mathrm{H}_{2} \mathrm{O}$ mixture at a flow rate of $600 \mathrm{sccm}$ (wet) overnight. The cell was then heated to $650^{\circ} \mathrm{C}$ and given time to equilibrate. The electrolyte used in this test contained no halide and was a 72:28 molar mixture of $\mathrm{Li}_{2} \mathrm{CO}_{3}: \mathrm{K}_{2} \mathrm{CO}_{3}$ plus extra $\mathrm{Li}_{2} \mathrm{CO}_{3}$ to account for lithium taken up by the anode, the fine pore and the matrix (these amounts were calculated using the initial rate of component lithiation in full scale stacks times 350 hours of expected cell life). The current collector plate in the anode tests was perforated by drilling holes in the plate to match up with the holes in the nickel push rod plate. Details on the anode components are given in Table 3-1. The matrix and the fine pore were filled to capacity with electrolyte and the anode was filled to 30 percent with electrolyte. The 30 percent value was chosen based on previous anode performance vs. percent fill data. The data for Anode Test \#1 are shown in Figure 3-26. The weight of electrolyte was converted to percent fill using an electrolyte distribution program which utilizes measured pore spectra for molten carbonate components. The results of overpotential vs. percent fill are shown in Figure 3-27. 
Baseline

$I=160 \mathrm{~mA} / \mathrm{cm}^{2}$

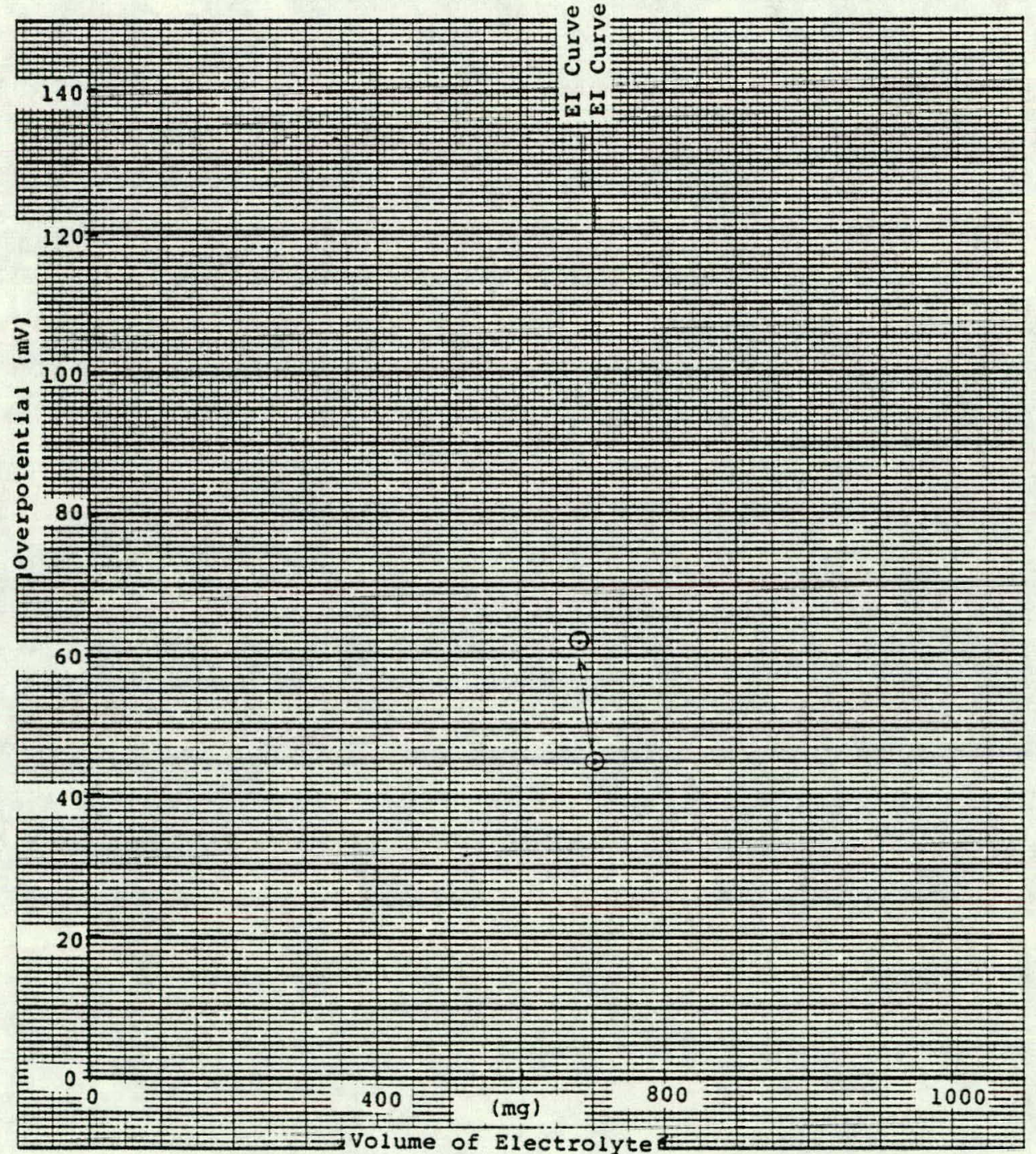

Figure 3-26. Half-Cell Anode Test \# 1 


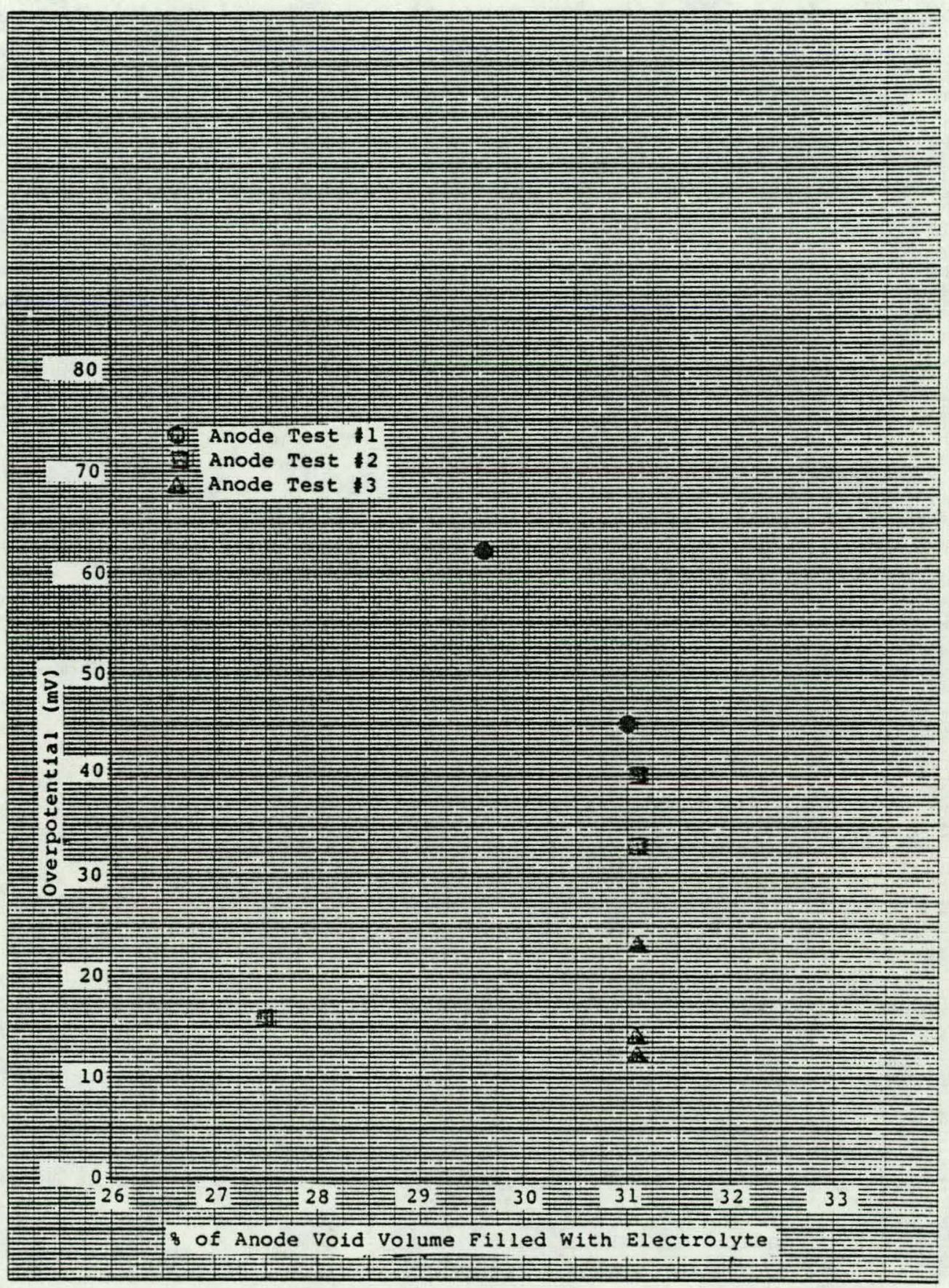

Figure 3-27. Anode Overpotential Vs. Percent Fill 
Anode Test \#2 - This test was similar to Anode Test \#1, except that the electrolyte contained 23 anion percent chloride (maintaining a 72:28 Li:K cation ratio) and $10 \mathrm{ppm} \mathrm{HCl}$ was introduced into the fuel. The data are shown in Figure $3-28$ and are converted to percent fill in Figure 3-27. It is not clear why the data falls below the baseline data. Chloride in the electrolyte may have lowered the contract angle between the nickel and the electrolyte. Several current vs. overpotential curves were taken at a relatively fast sweep rate of $400 \mathrm{~mA} / \mathrm{min}$. Figure $3-29$ shows one of three curves taken at $655 \mathrm{mg}$ of electrolyte, all of which were repeatable. Figure 3-30 shows data taken with $609 \mathrm{mq}$ of electrolyte in the cell.

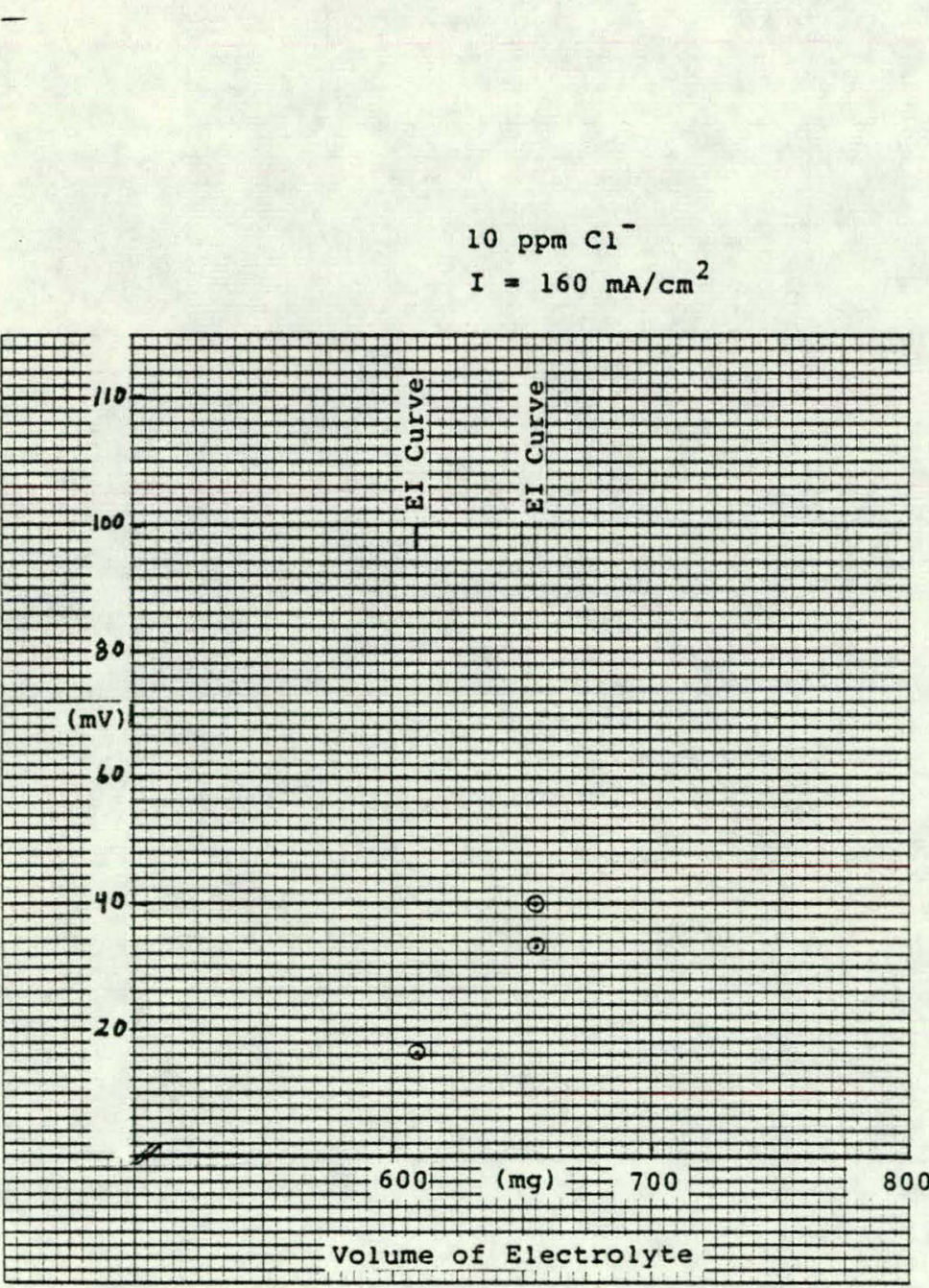

Figure 3-28.

Half-Cell Anode Test \#2. 

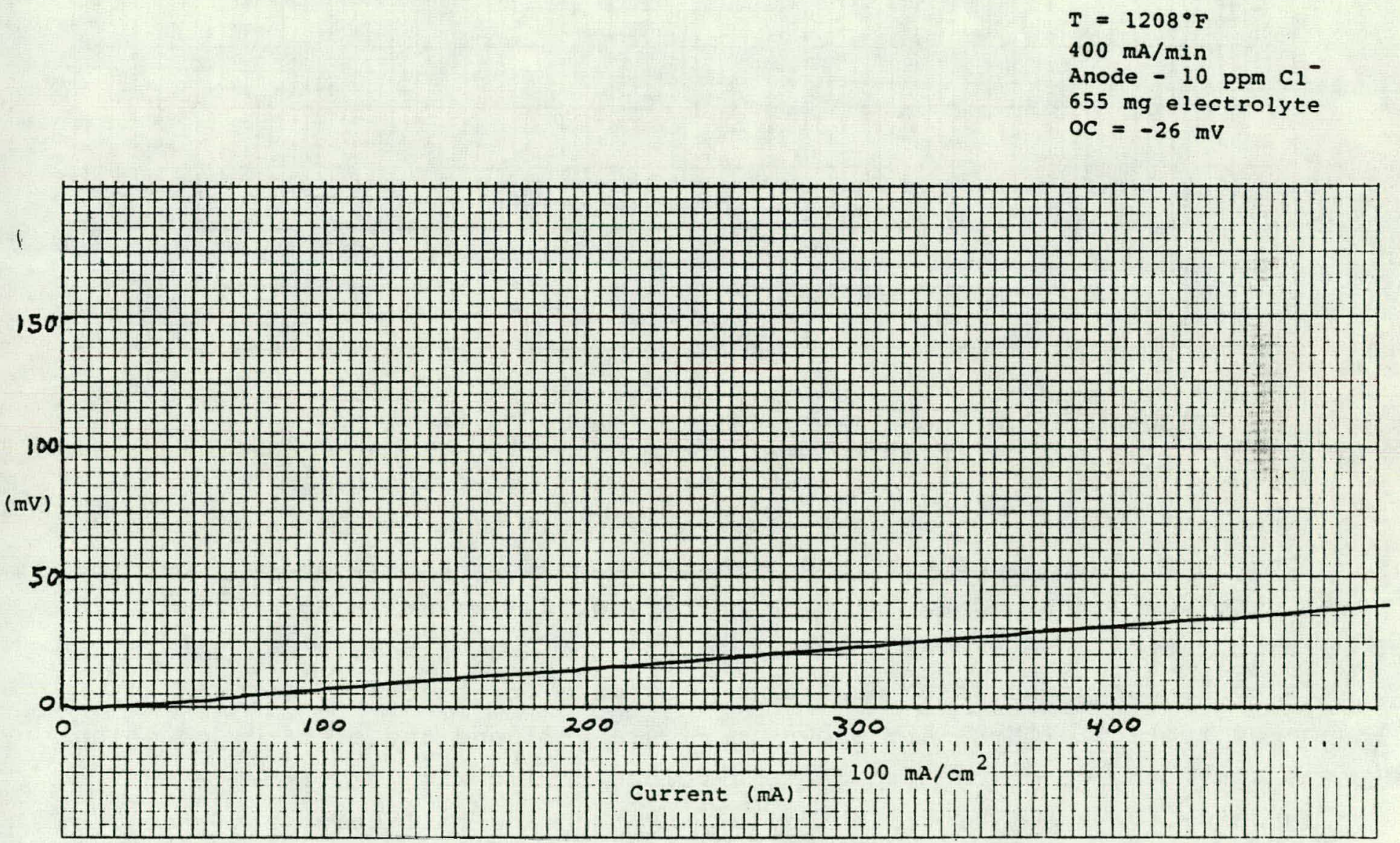

Figure 3-29. Anode Test \#2 Performance Curve With $655 \mathrm{mg}$ of Electrolyte in the Cell 

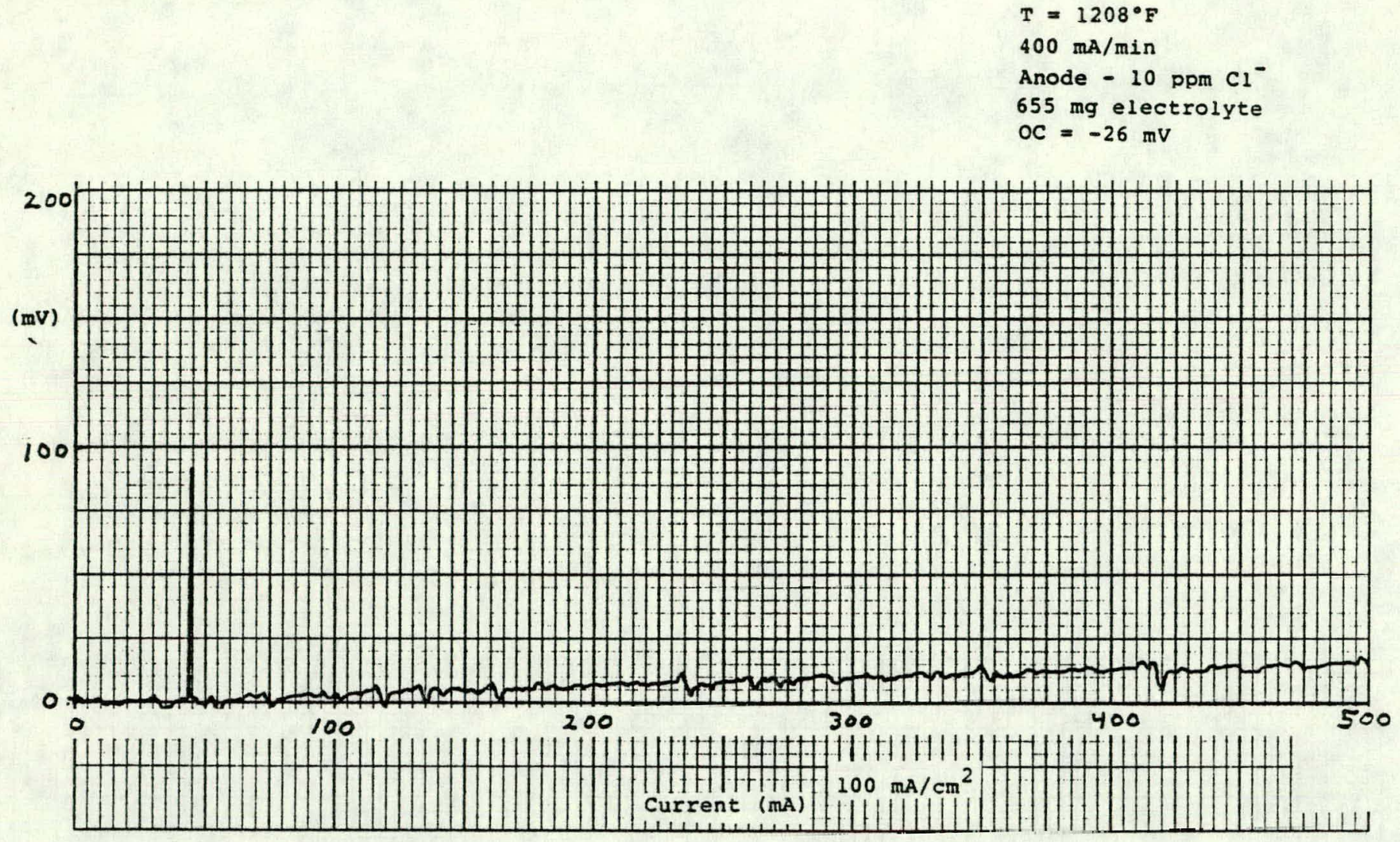

Figure 3-30. Anode Test \#2 Performance Curve With $609 \mathrm{mg}$ of Electrolyte in the Cell

Anode Test \#3 - This test was similar to Anode Test \#2, except that the electrolyte contained 23 anion percent fluoride (maintaining a $72: 28$ Li:K cation ratio). No $\mathrm{HF}$ was introduced into the fuel since it was determined that this was unnecessary due to the low vapor pressures of LiF and $\mathrm{KF}$. The overpotential data are shown in Figure 3-31 and the electrolyte weight was converted to percent anode void volume filled with electrolyte in Figure 3-27. Again, it is not clear why the data fall below the baseline data. Three current vs. overpotential curves were taken at each point in Figure 3-31 and are presented in Figures 3-32 to 3-34. A potential vs. time 
curve similar to that taken under Cathode Test \# 9 was also taken on this test (Figure 3-35). The curve temporarily falls below $0 \mathrm{mV}$ overpotential after the current was interrupted. This was not observed in repeats of this curve, but is possibly due to a slower diffusion rate away of fluoride ions away from the anode than the reference, due to the porosity of the anode and the smoothness of the reference.

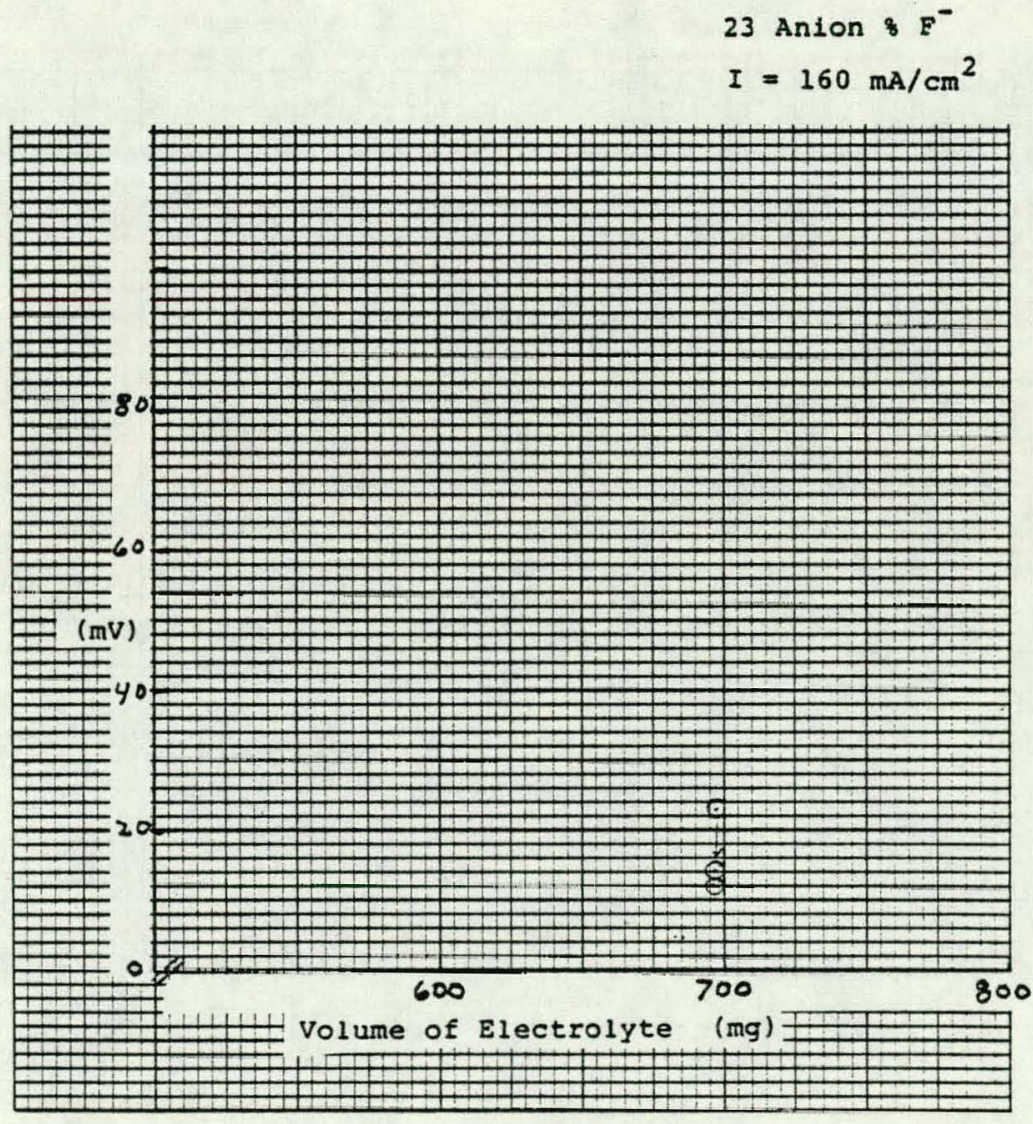

Figure 3-31.

Half-Cell Anode Test \#3 

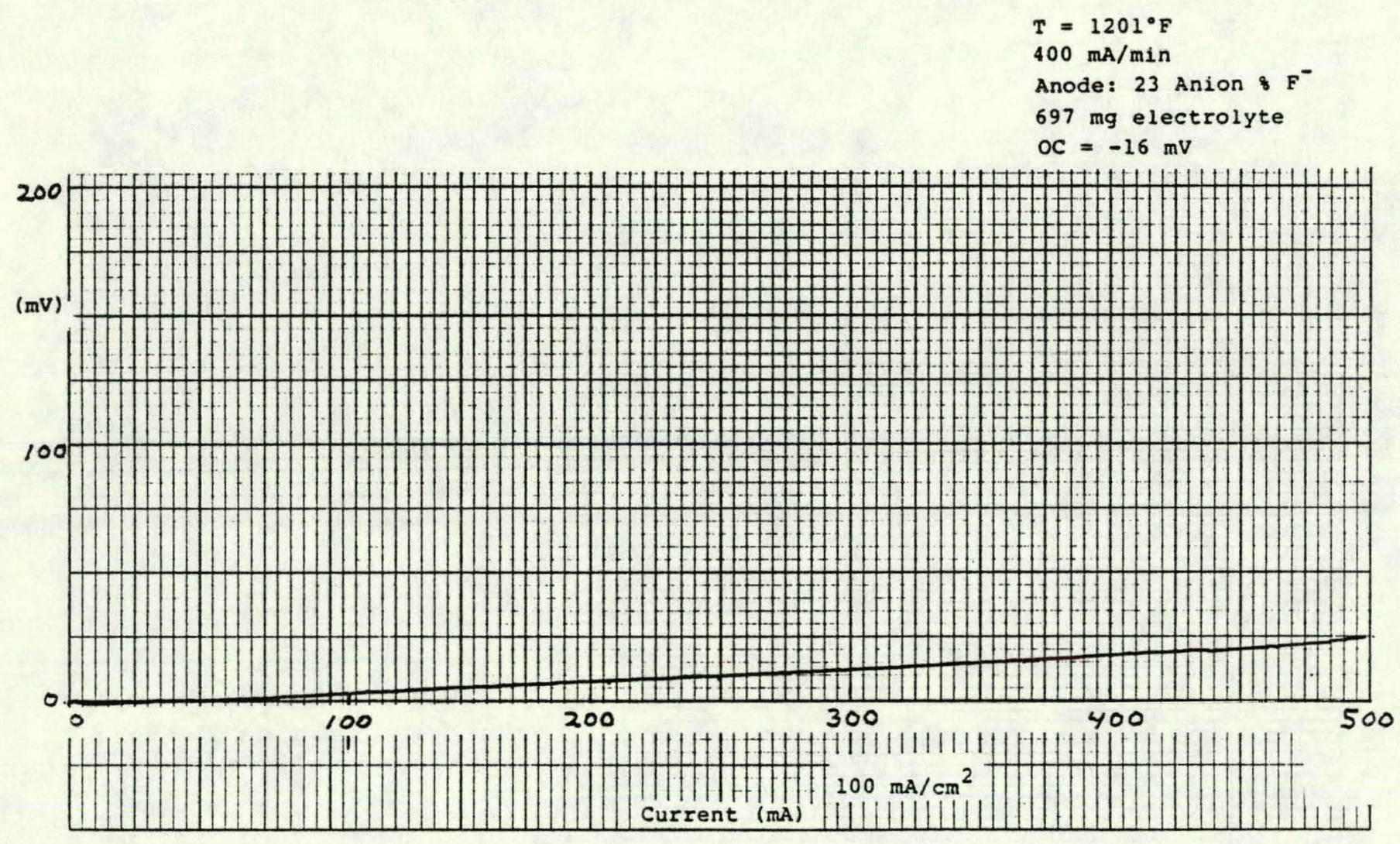

Figure 3-32. Anode Test \#3 Performance Curve \#1 

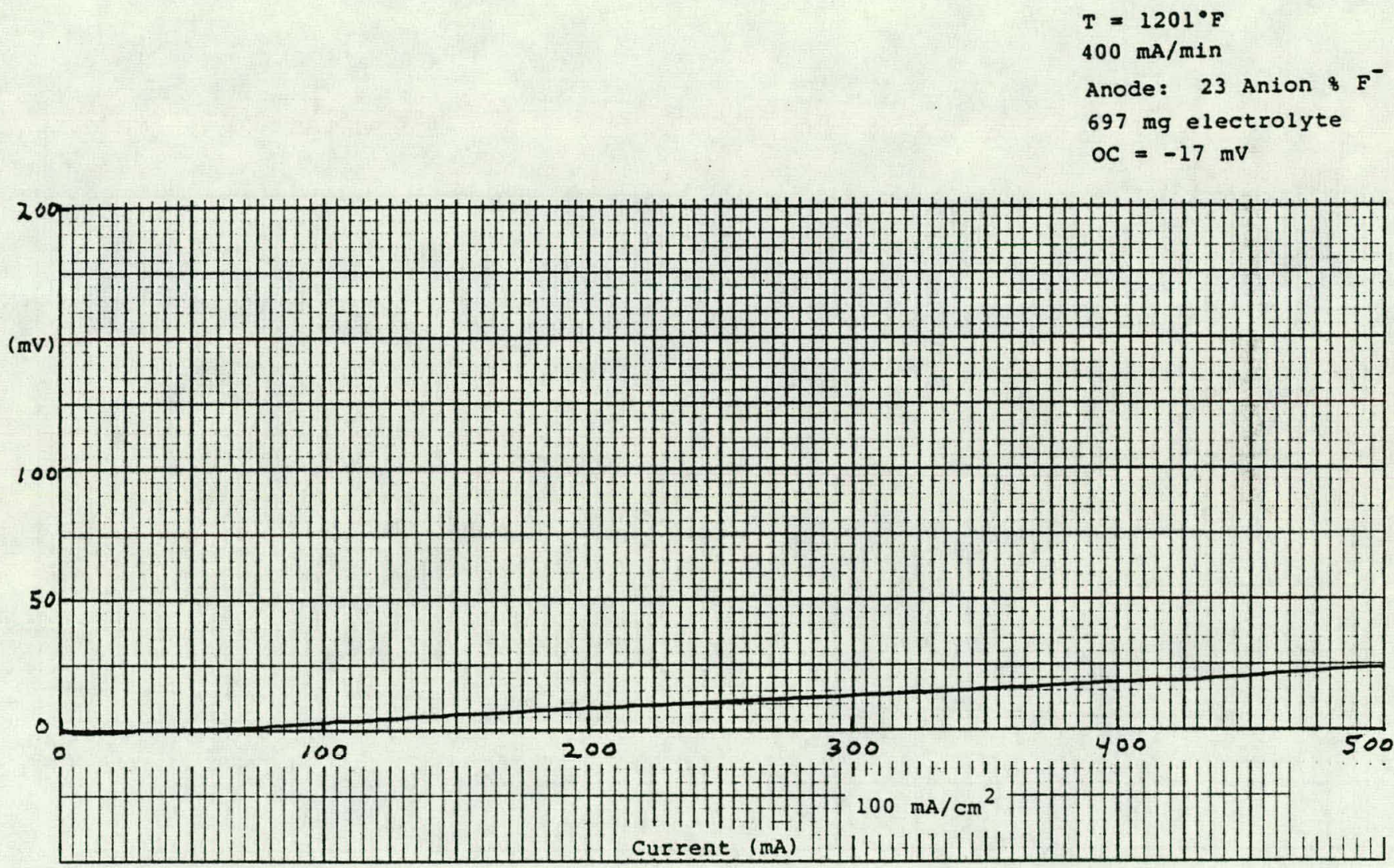

Figure 3-33. Anode Test \#3 Performance Curve \#2 

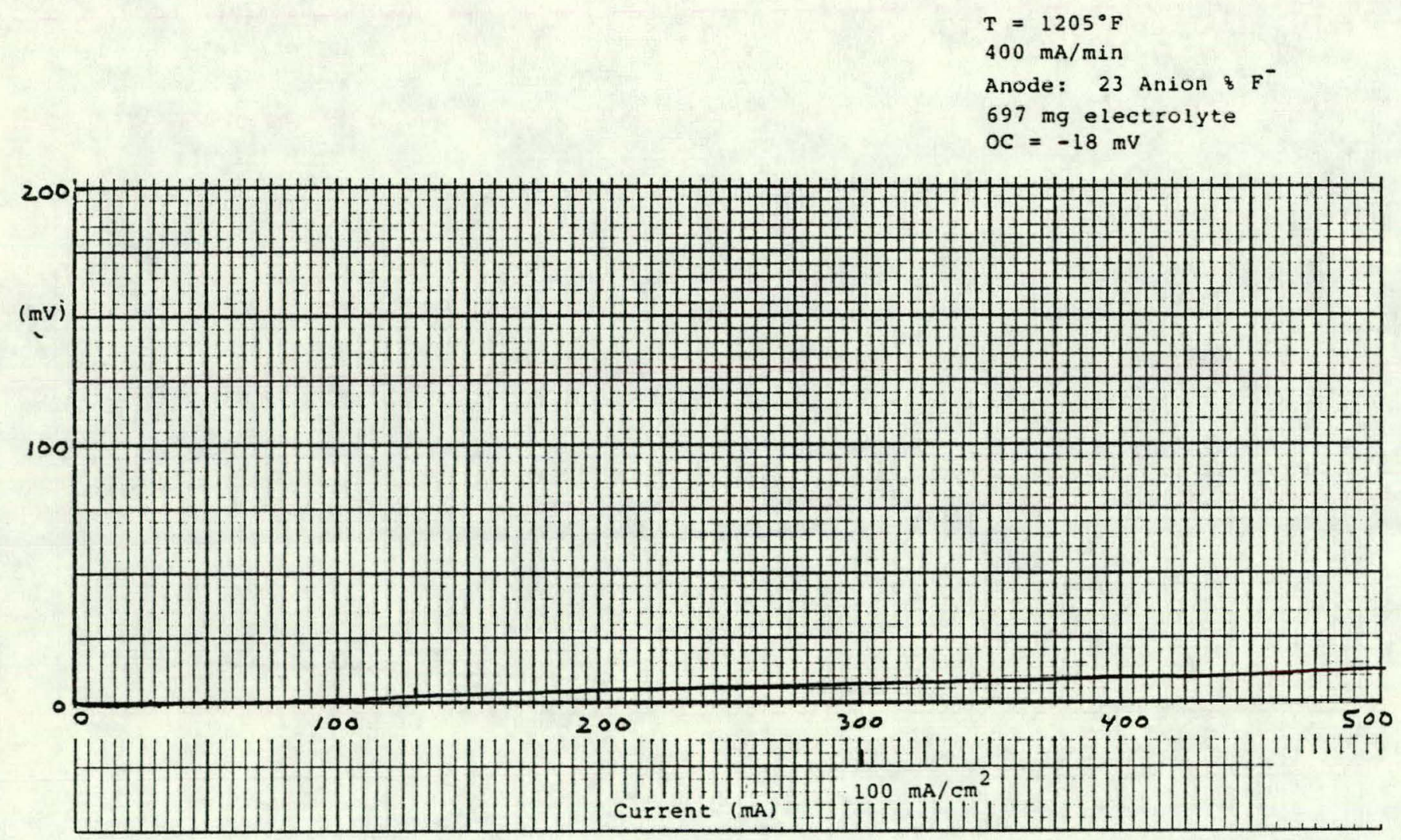

Figure 3-34. Anode Test \#3 Performance Curve \#3 


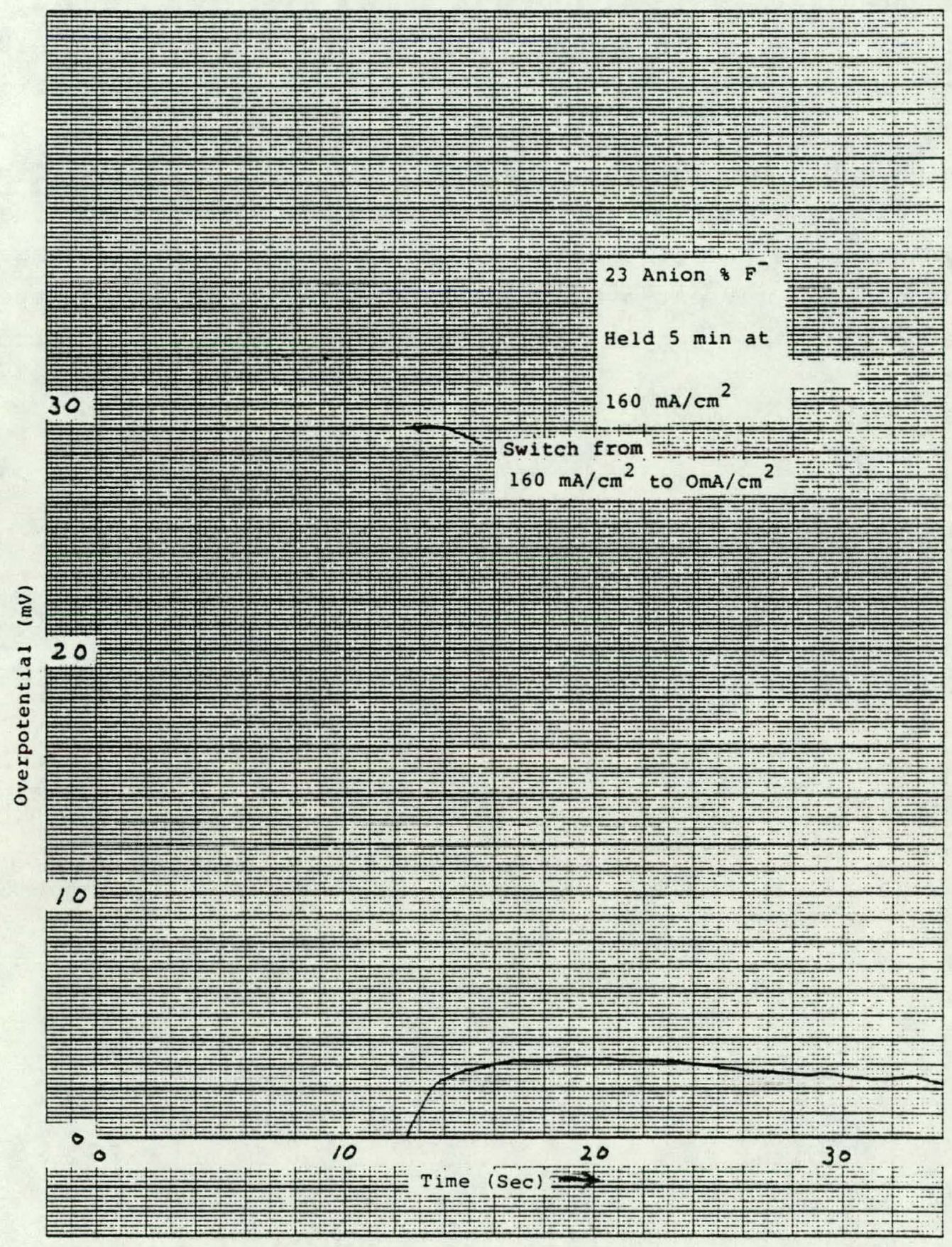

Figure 3-35. Anode Test \#3 Potential Sweep After Current Step 


\section{Conclusions}

Anode and cathode half-cell configurations were developed which allowed half-cell tests to be conducted using $\mathrm{LiAlO}_{2}$ tapes instead of $\mathrm{LiAlO}_{2}$ tiles. Performance results from tests having halide in the electrolyte clearly show that chloride is detrimental to the cathode and that the greater the concentration of chloride, the greater the effect. Fluoride, however, had little affect on the cathode. Anodes were not adversely affected by halide in the electrolyte. Halide ion concentration gradients were evident in slow current-overpotential sweeps and potential-step tests repeated what was seen in the concentration polarization stury. 
CORROSION TESTS

\section{Introduction}

The objective of the corrosion tests was to determine the influence of chlorides and fluorides on the corrosion of cathode-side alloys of construction in molten carbonate electrolytes. The corrosion tests were conducted at $760^{\circ} \mathrm{C}$ for 1000 hours under a pressure of one atmosphere. Three alloys, AISI 316, AISI 310, and Incoloy 825 ; were evaluated in an electrolyte composed of 72 mole percent $\mathrm{Li}_{2} \mathrm{CO}_{3}$ and 28 mole percent $\mathrm{K}_{2} \mathrm{CO}_{3}$ converted to contain 3.1 anion percent chloride or fluoride. The three alloys were also evaluated in an electrolyte of similar composition, but containing no halide ions, to establish a baseline corrosion rate.

\section{Experimental}

A schematic of the test set-up is shown in Figure 3-36. Two-zoned gas saturators were used to introduce water into the cell. An all glass saturator was used to introduce chloride. It was determined that for each cell, two saturators running in parallel, one filled with a halide-water solution and the other just water, would be the least expensive method to introduce halide into the gas stream. 


\section{SATURATORS}

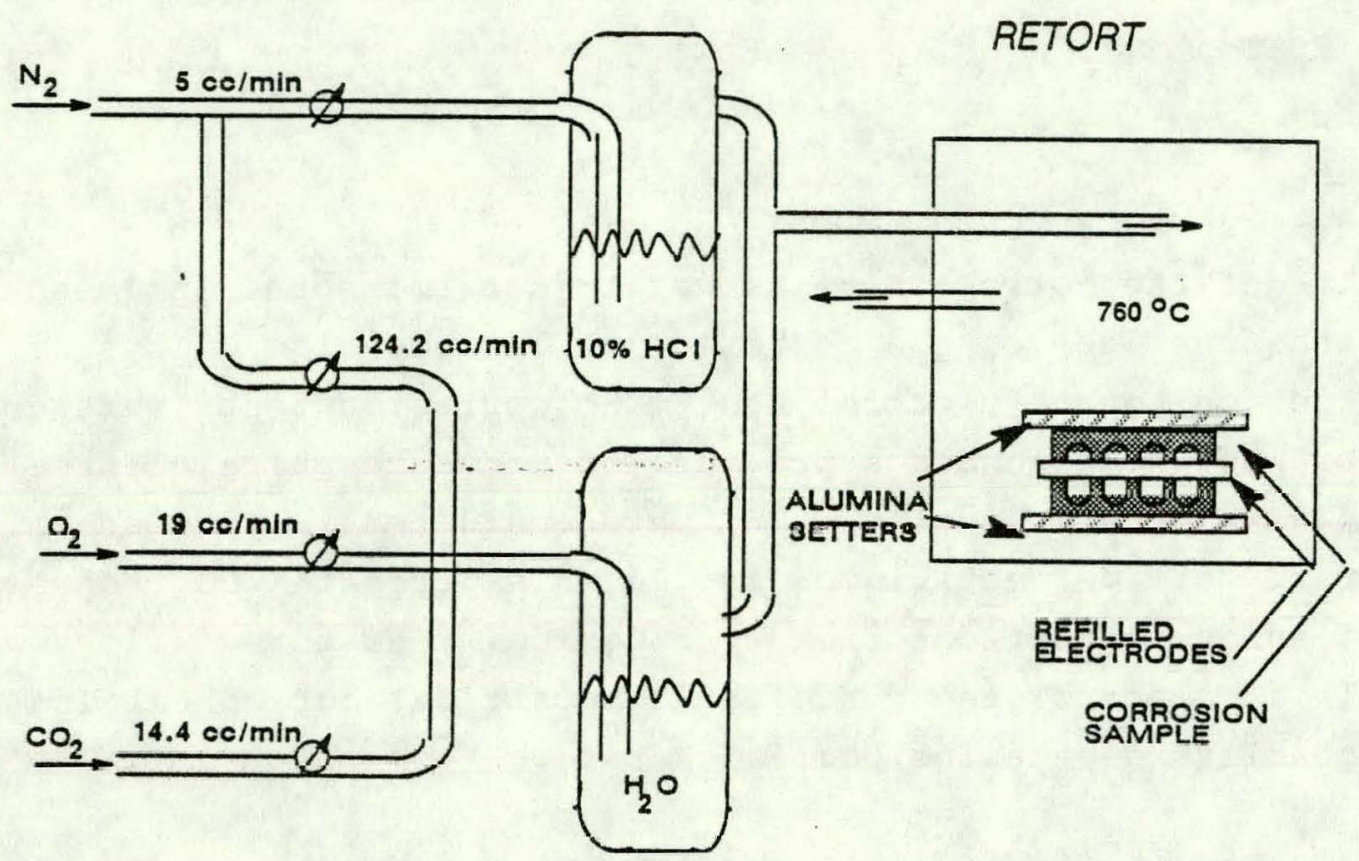

Figure 3-36. Schematic of Retort Test

'Iest specimens of AISI 316 and AISI 310 stainless steels and Incoloy 825 were wet ground on 240-grit paper, washed in 20 percent nitric acid solution, rinsed and dried. All samples measured $1.27 \mathrm{~cm} \times 2.54 \mathrm{~cm}$. The thicknesses of AISI 316, AISI 310, and Incoloy 825 were $0.114 \mathrm{~cm} \mathrm{x} 0.152 \mathrm{~cm}$, and $0.033 \mathrm{~cm}$, respectively. The specimens were sandwiched between prefilled nickel electrodes to simulate conditions in a stack and placed in a retort at $760^{\circ} \mathrm{C}$, as shown in the schematic. The nickel electrode was prefilled with 20 grams of a molten carbonate electrolyte having a composition of 72 mole percent $\mathrm{Li}_{2} \mathrm{CO}_{3}, 28$ mole percent $\mathrm{K}_{2} \mathrm{CO}_{3}$ converted to contain 3.1 anion percent halide.

The oxidant composition was 9.5 mole percent $\mathrm{O}_{2}, 7.2$ mole percent $\mathrm{CO}_{2}$, 64.6 mole percent $\mathrm{N}_{2}$ and 18.7 mole percent $\mathrm{H}_{2} \mathrm{O}$. In addition, in one test, a portion of the $\mathrm{N}_{2}$ flow was diverted to a saturator containing 10 percent 
hydrochloric acid and held at a temperature calculated to provide $1.0 \mathrm{ppm}$ chloride in the atmosphere to keep the chloride in the electrolyte from evaporating. The evaporation of fluoride from the electrolyte was calculated to be negligible over the test period. Therefore, fluoride was not added to the gas stream. All tests were interrupted at 500 hours for specimen weight determination but only the 1000 hour specimens were fully evaluated.

The post-test specimens were washed in acetic acid to remove residual electrolyte, rinsed in distilled water, dried and weighed. Metallographic crosssections of the specimens were prepared by mounting the specimens in a phenolic resin which had been previously examined with a scanning Electron Microscope (SEM) and determined by Energy Dispersive Spectroanalysis (EDS) to be free of chlorides. Elemental X-Ray maps of the oxide layers on the control and chloride test specimens were obtained using the SEM. The specimens were obtained using the SEM. The specimens from the fluoride test were examined with a Scanning Electron Microprobe since fluorine could not be detected with SEM. Both the SEM and Microprobe analyses were conducted at the United Technologies Research Center (UTRC).

Microstructural features of the pre-test and post-test specimens are shown in Figures $3-37$ and 3-40. The post-test AISI 316 and AISI 310 specimens exposed to halide exhibited base metal microstructures similar to the control specimens, Figures $3-38$ and $3-39$. The Incoloy 825 post-test specimens base metal microstructures which varied in appearance depending on whether the chloride, fluoride, or no halide was present. The scale morphologies of the post-test specimens varied with the test environment. 


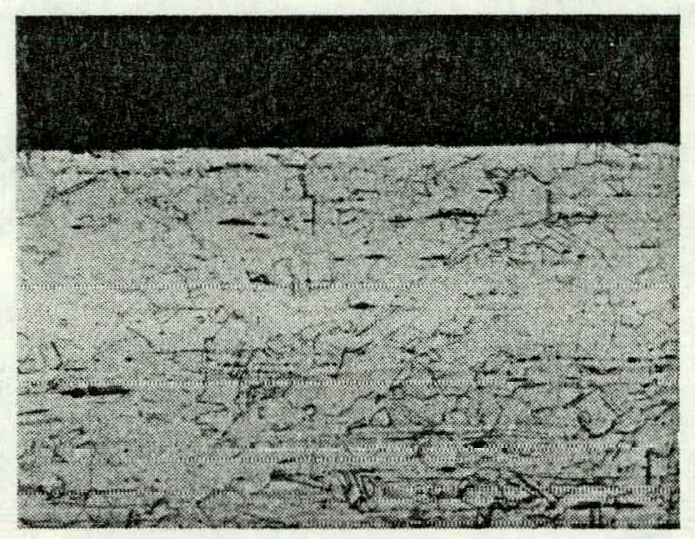

a. AISI 316

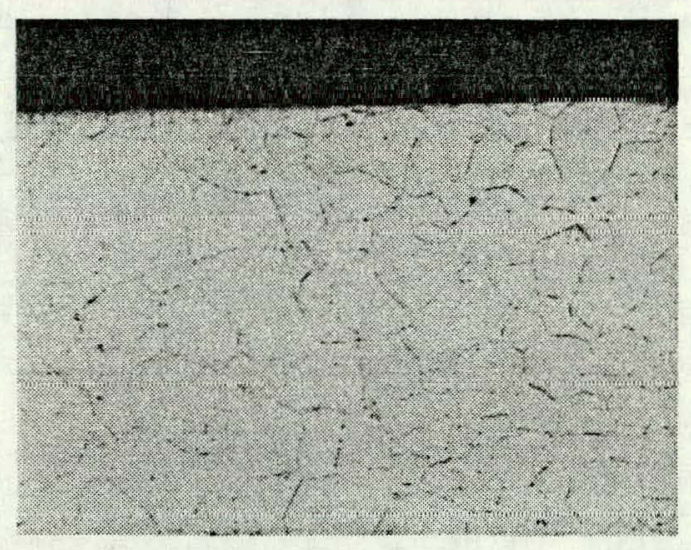

b. AISI 310

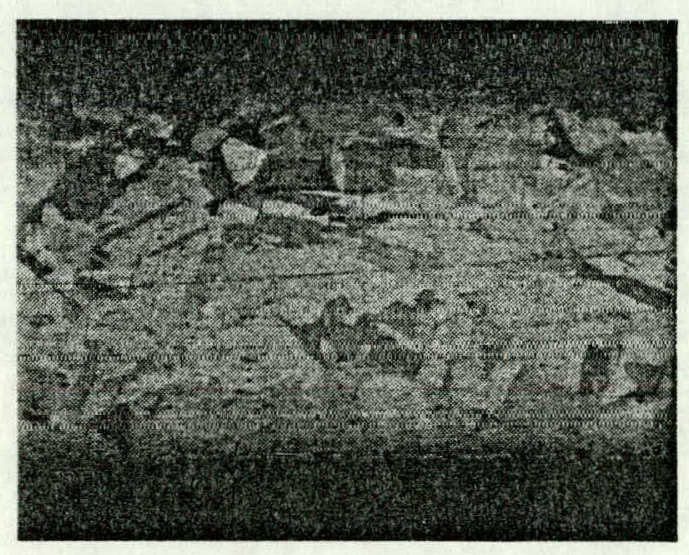

c. Incoloy 825

Figure 3-37. Photomicrograph of the Pre-Test Alloys (oxalic/electrolytic etch) 


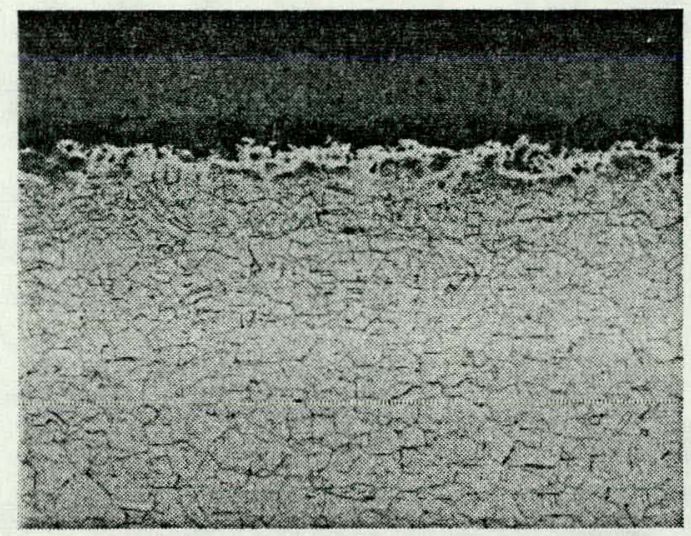

a. Halide-free

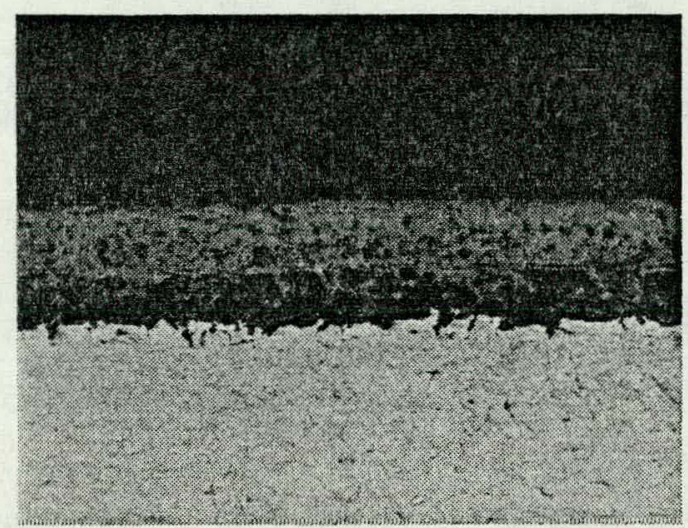

b. $10 \mathrm{ppm} \mathrm{Cl}$

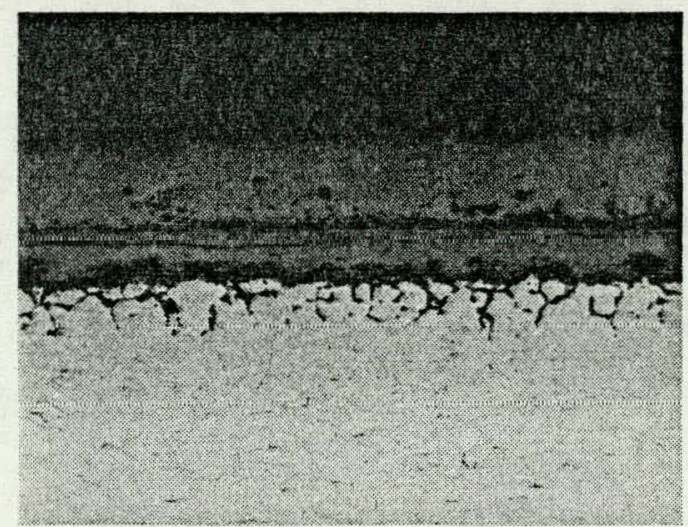

c. 10 ppm F

Figure 3-38. Photomicrographs of AISI 316 Alloy Tested for 1000 Hours in a Molten Carbonate Environment at $760^{\circ} \mathrm{C}$ (oxalic/electrolytic etch) 


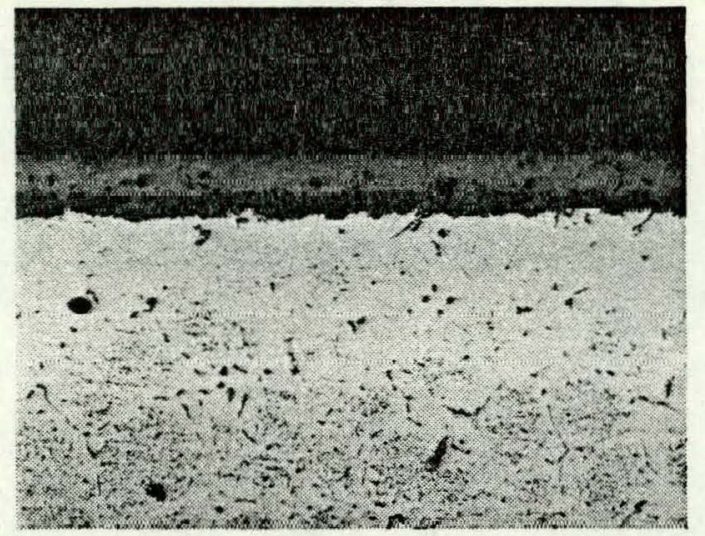

a. Halide-free

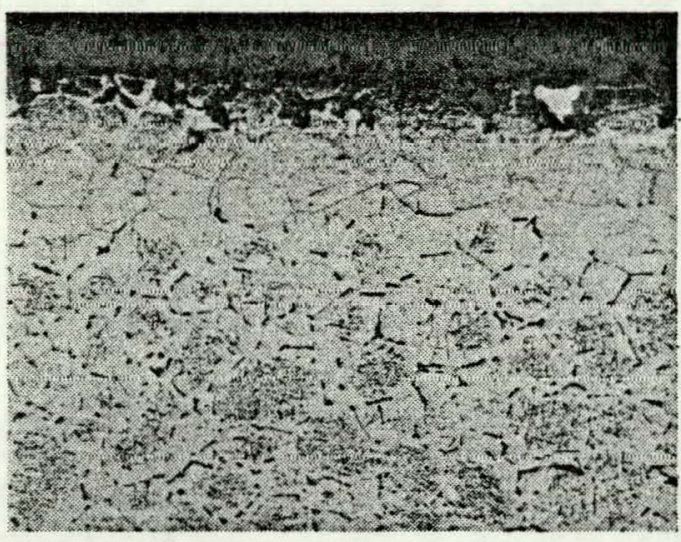

b. $10 \mathrm{ppm} \mathrm{Cl}$

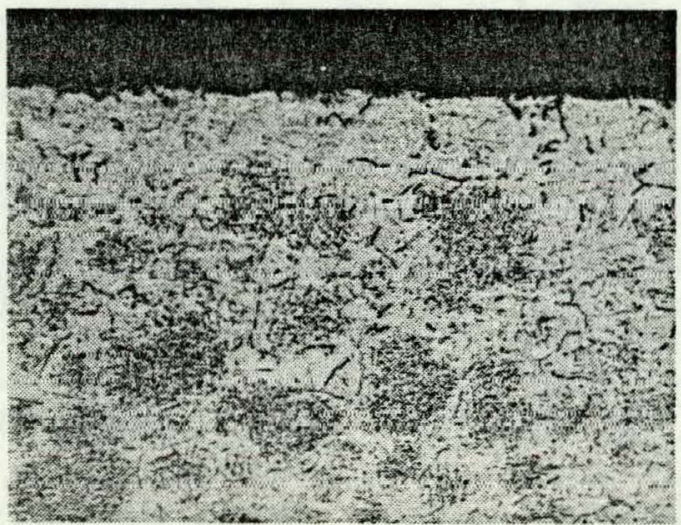

c. $10 \mathrm{ppm} \mathrm{F}$

Figure 3-39. Photomicrographs of AISI 310 Alloy tested for 1000 Hours in a Molten Carbonate Environment at $760^{\circ} \mathrm{C}$ (oxalic/electrolytic etch) 


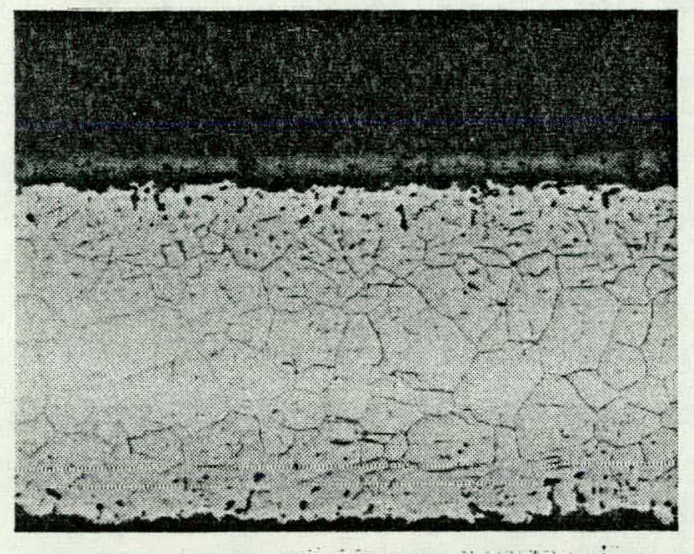

a. Halide-free

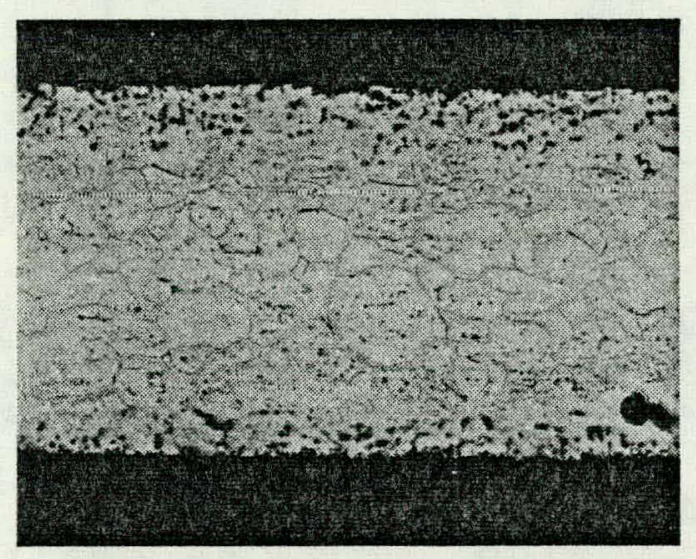

b. $10 \mathrm{ppm} \mathrm{Cl}$

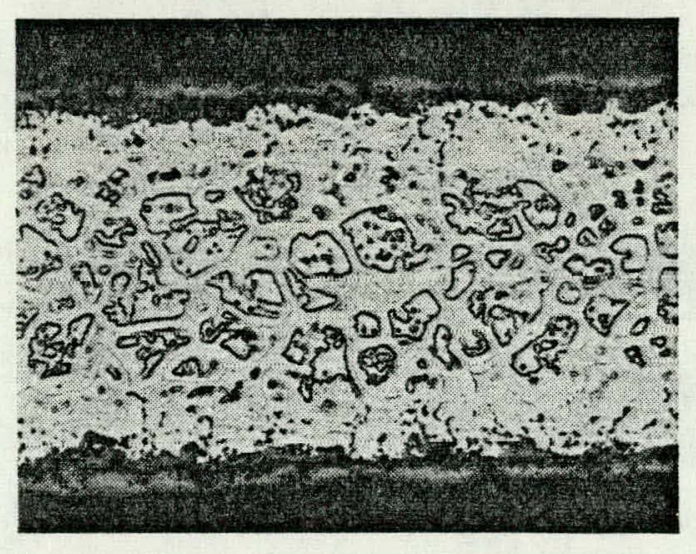

c. $10 \mathrm{ppm} \mathrm{F}$

Figure 3-40. Photomicrographs of Incoloy 825 Alloy Tested for 1000 Hours in a Molten Carbonate Environment at $760^{\circ} \mathrm{C}$ (oxalic/electrolytic etch) 
The extent of metal loss, maximum oxide penetration and total metal affected were measured for each specimen by a technique described schematically in Figure 3-41. The pertinent metallographic data, as well as weight change data, are compiled in Table 3-3.

These data show that the corrosion of the test alloys was accelerated by the presence of both chloride and fluoride in the electrolyte. Apparently the halides affected the morphology and adherence of the protective scales formed The fluoride was more aggressive than the chloride to all three alloys.

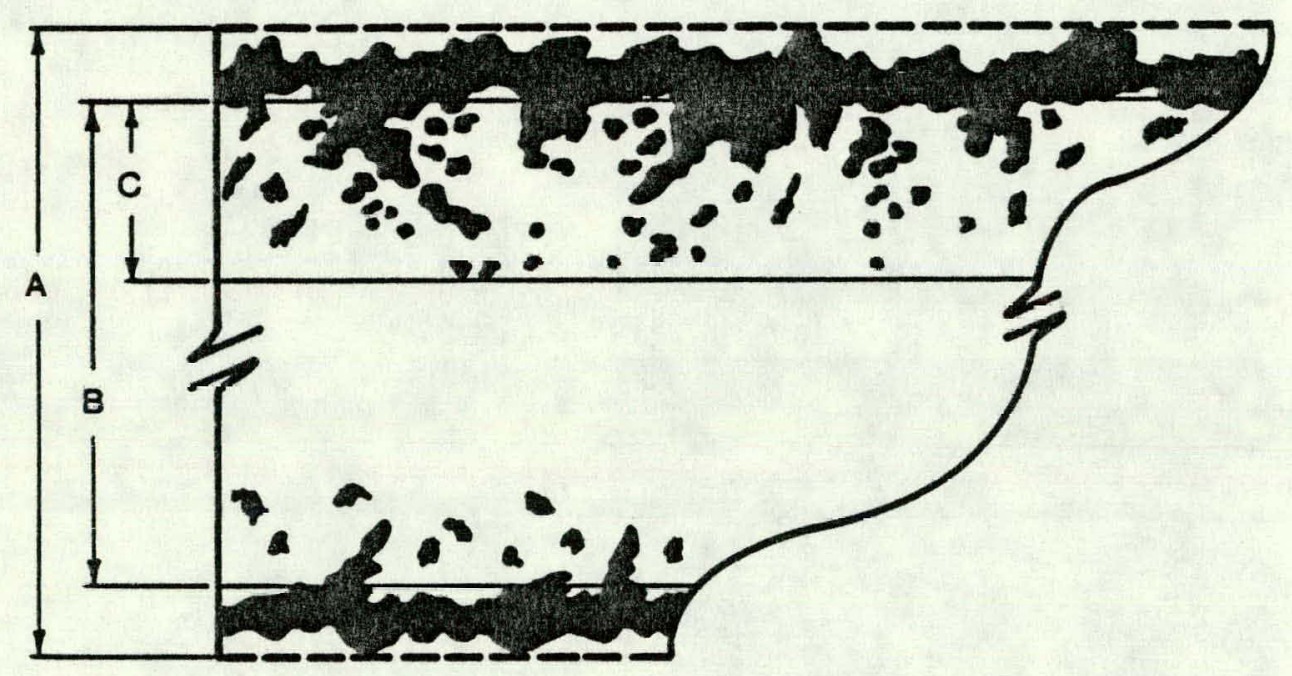

Metal Loss (mils/side) $\left[\left(\frac{A-B}{2}\right)\right]$

Maximum Penetration (mils/side) [C]

Total Metal Affected (mils/side) $\left[\left(\frac{A-B}{2}+C\right)\right]$

Figure 3-4l. Schematic of the Metallographic Technique Used for the Corrosion Tests 
Table $3-3$

Summary of the 1000-Hour Metallographic and Weight Change Data

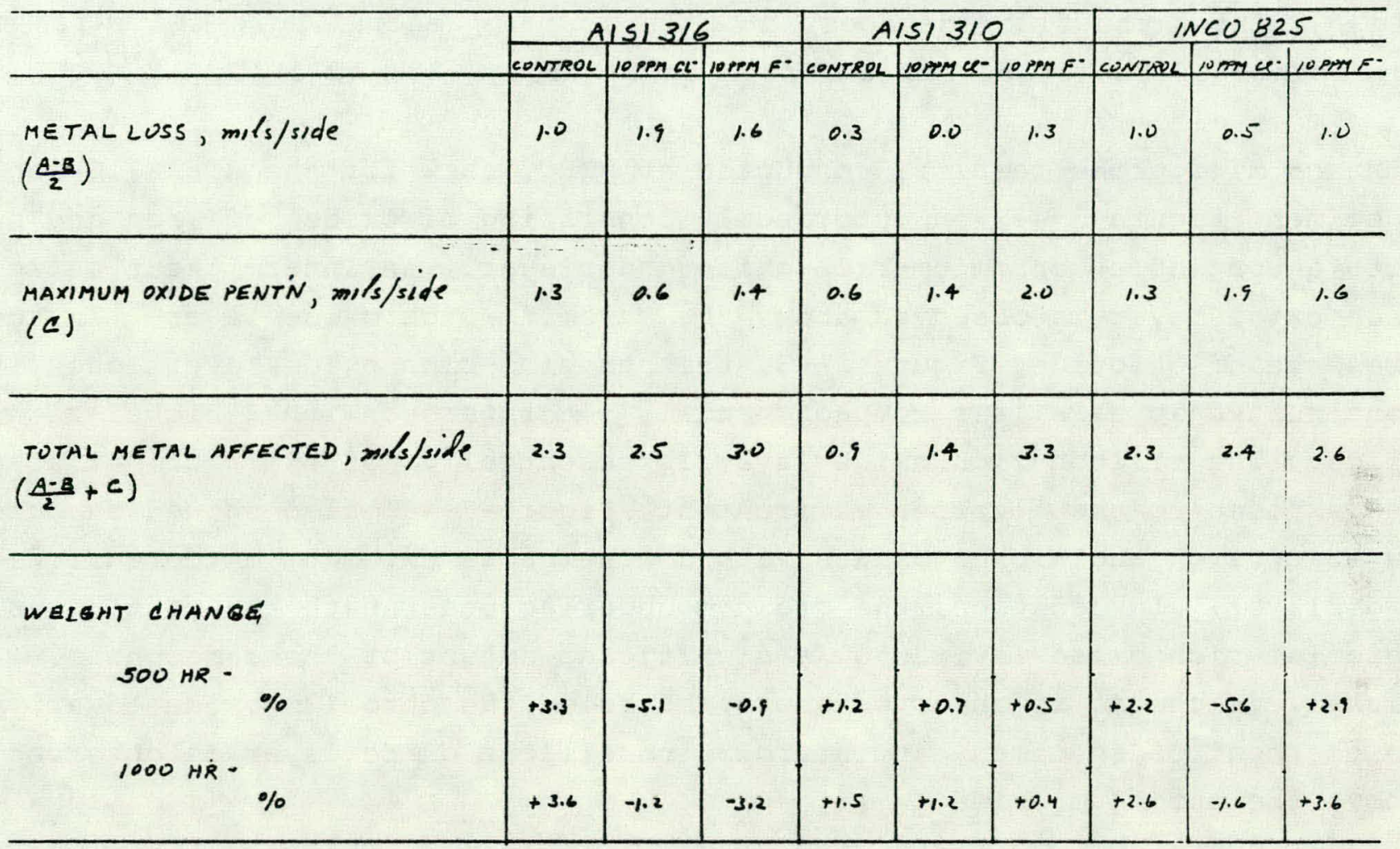

In halide-free and chloride-containing environments, the AISI 310 alloy was the most resistant of the alloys tested. However, in the presence of fluoride, attack of the AISI 310 alloy was comparable to that of AISI 316 and somewhat higher than that of Incoloy 825 (Table 33 ). The Incoloy 825 alloy showed the most consistent rate of attack in the three environments in which it was tested. 
From the 1000-hour weight change data (Table 3-3) it is deduced that the halide ions aggravate the corrosion of the test alloys by causing the oxide layers to spall. For the AISI 316 and AISI 310 alloys, the fluoride appears to have a stronger effect on oxide spalling than does the chloride. For Incoloy 825 , the weight change data suggests that chloride induces spalling, whereas the fluoride does not. This is in general agreement with the appearance of the oxide scales shown in Figures $3-38$ and $3-40$.

SEM and Microprobe results, conducted at UTRC, show for the AISI 316 control specimen, Figure 3-42, an outer scale consisting of oxides of iron and nickel with a continuous chromium-rich oxide underlayer. An intermittent siliconrich oxide layer is observed above the chromium-rich oxide layer. In the presence of chloride, Figure 3-43, the chromium-rich oxide layer loses its continuity, appears less compact, and is interspersed with a nickel-rich oxide. The silicon-rich oxide layer is essentially non-existent. The specimen exposed to the fluoride environment, Figure 3-44, also showed an outer layer of iron and nickel oxides with a continuous chromium oxide enriched underlayer. In addition, the grain boundaries underneath the continuous chromium-rich oxide layer show a significant amount of the same phase. Nickel enrichment is observed above and below the chromium oxide layer. As in the control specimen, an intermittent silicon oxide layer is observed above the chromium oxide layer. 


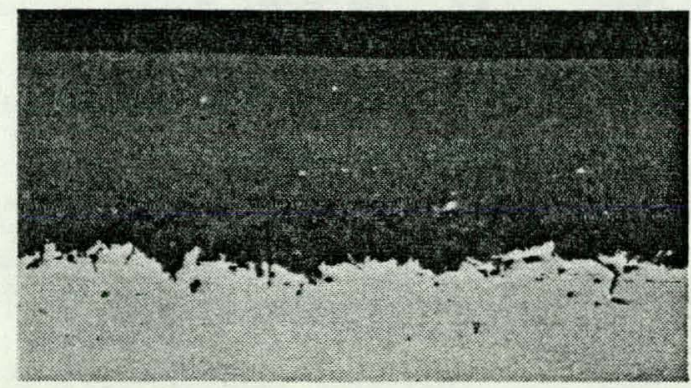

BEI
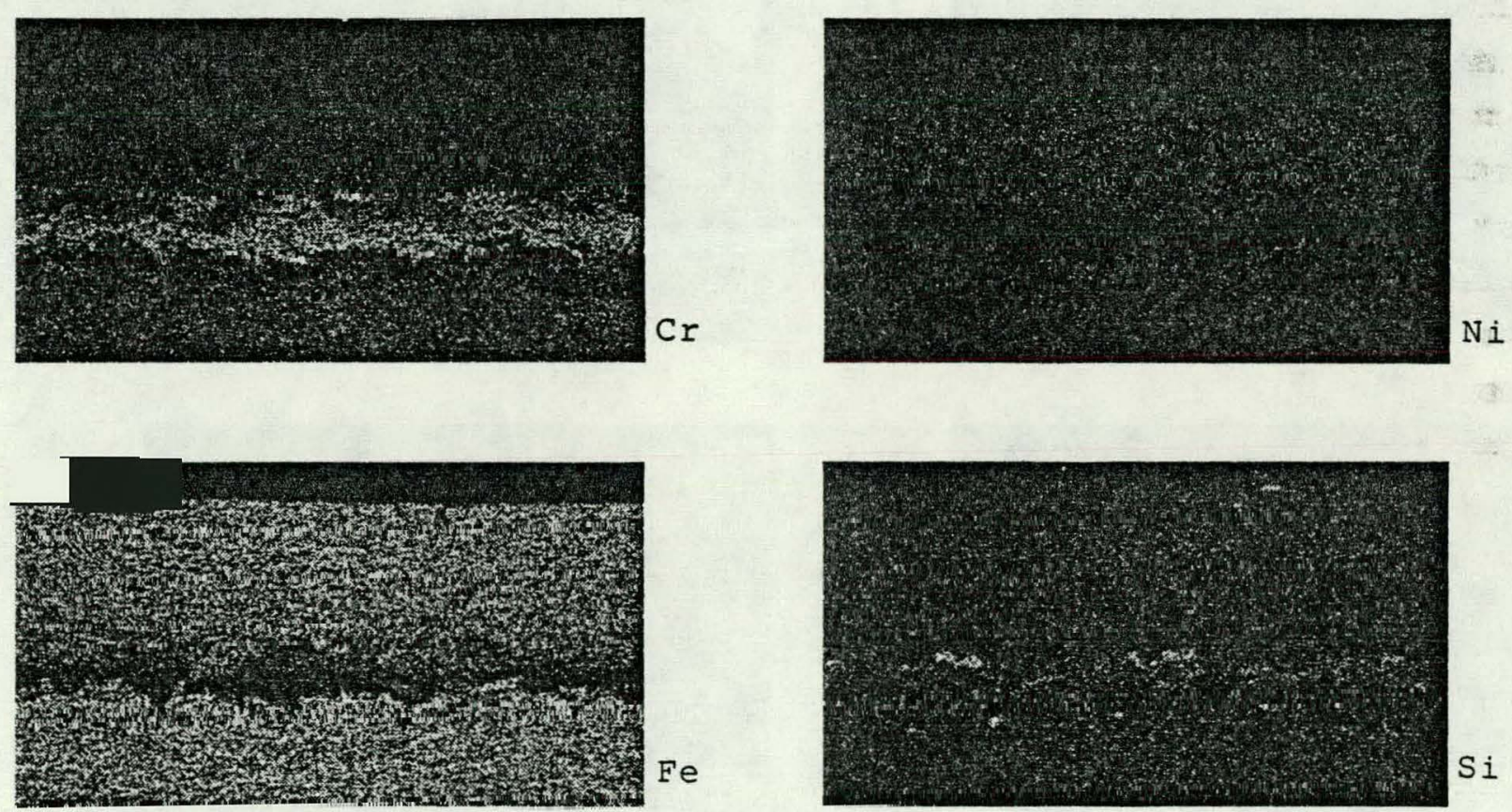

Si

Figure 3-42. Backscatter Electron Image (BEI) and Elemental X-Ray Maps of the AISI 316 Control Specimen Tested for 1000 Hours at $760^{\circ} \mathrm{C}$ in a Molten Carbonate Environment Free of Halides 


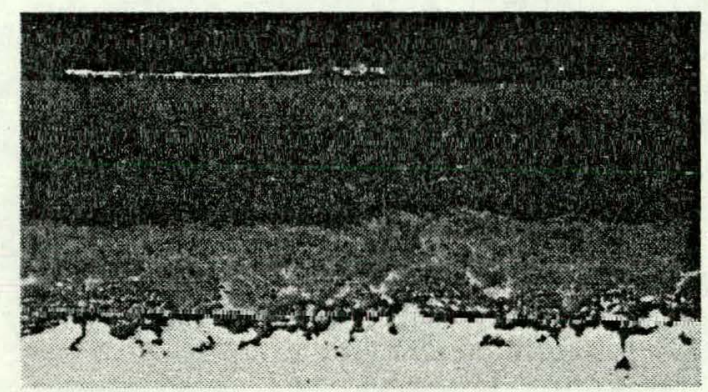

BEI
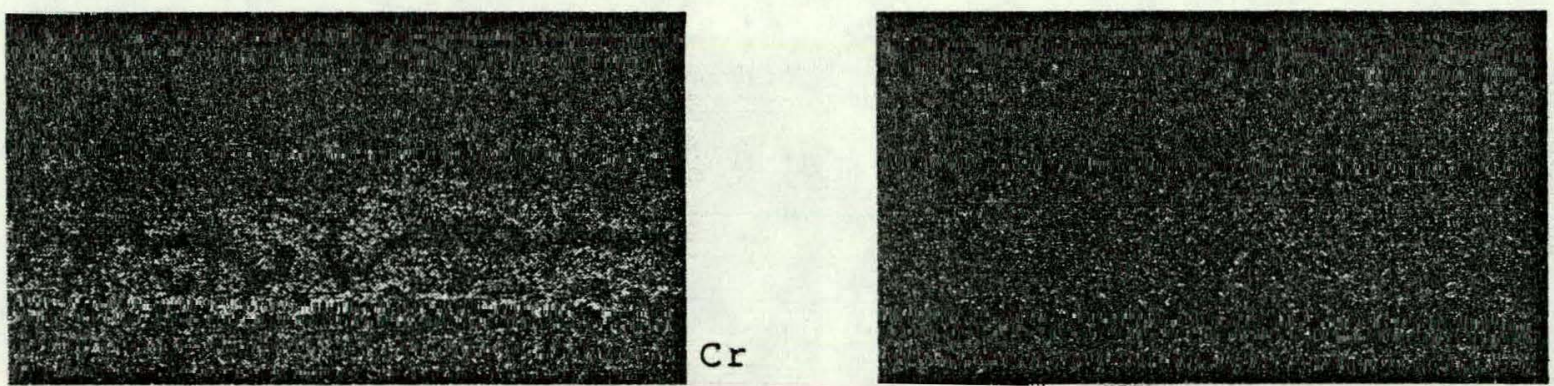

$\mathrm{Ni}$
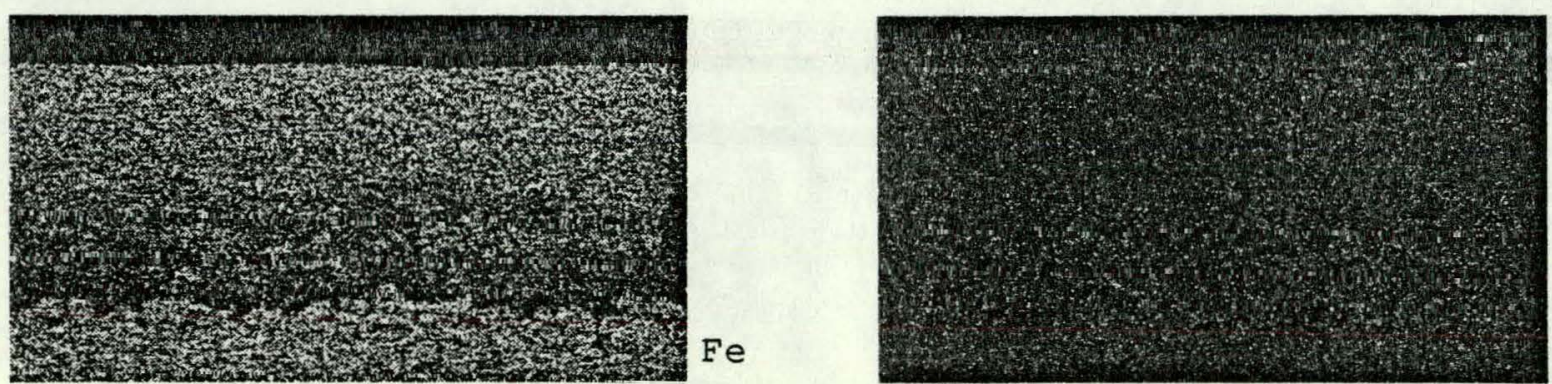

Si

Figure 3-43. Backscatter Electron Image (BEI) and Elemental X-Ray Maps of the AISI 316 Specimen Tested for 1000 Hours at $760^{\circ} \mathrm{C}$ in a Molten Carbonate Environment Containing $10 \mathrm{ppm} \mathrm{Cl}$ in the oxidant Gas 

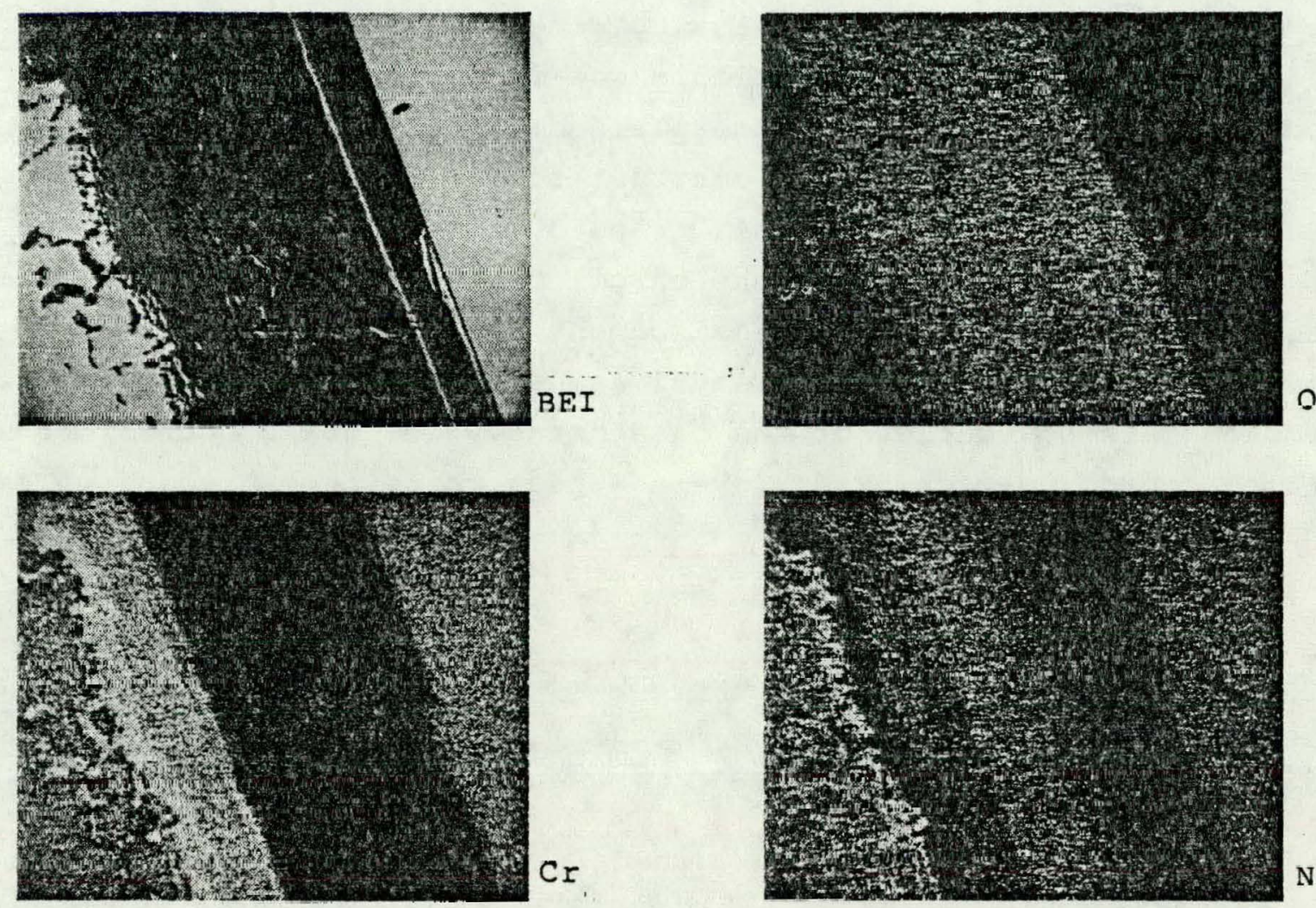

$\mathrm{N} i$
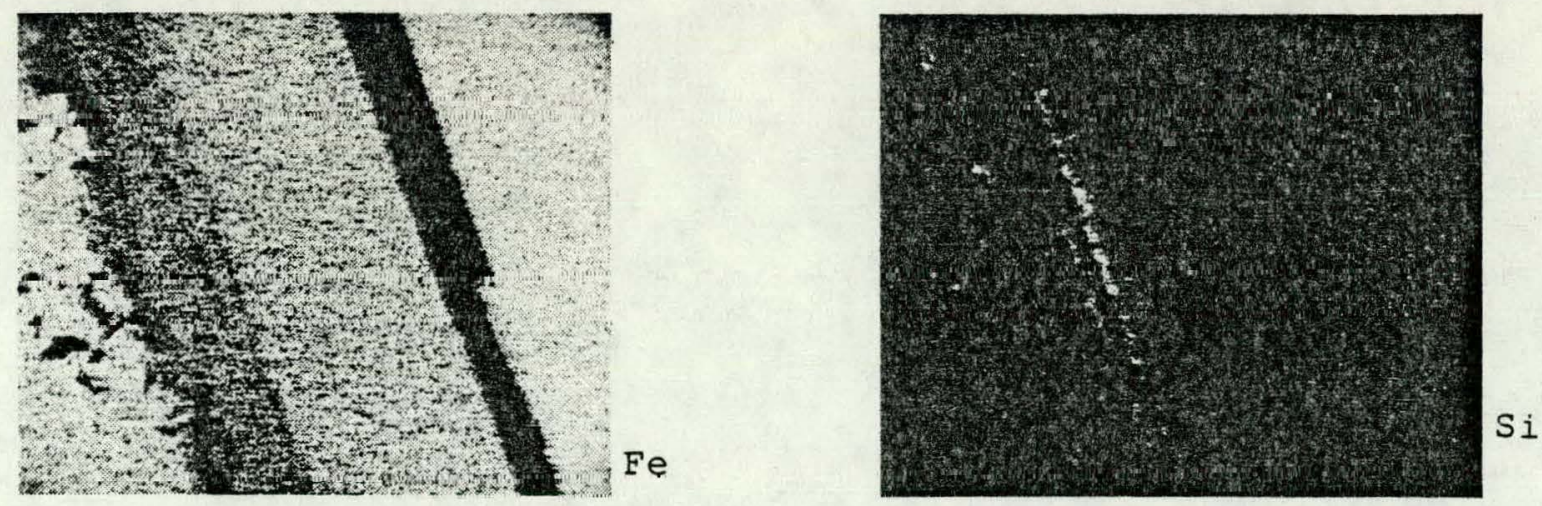

Figure 3-44. Backscatter Electron Image (BEI) and Elemental X-Ray Maps of the AISI 316 Specimen Tested for 1000 Hours at $1400^{\circ} \mathrm{F}$ in a Molten Carbonate Environment Containing $10 \mathrm{ppm} F$ in the Oxidant Gas 
Figures 3-45 to 3-47 show the elemental $X$-Ray maps of the oxide layers on the AISI 310 alloy. The control specimen, Figure 3-45, shows an oxide composition very similar to the AISI 316 alloy specimens discussed above. In the presence of chloride, the chromium-rich oxide layer takes on a peculiar ribbed appearance which could not be explained. This layer is intermixed with iron and nickel-rich oxides in contrast to the relatively pure chromiumrich oxide layer in the control sample. Again, intermittment enrichment of silicon oxide is evident on top of the chromium-rich oxide layer. Specimens exposed to the fluoride-containing environment show similar elemental distribution, but the chromium-rich oxide layer appears thinner and extends into the outermost grain boundaries of the base metal. The grain boundaries underneath the chromium-rich oxide layers appear to be depeleted of chromium. 


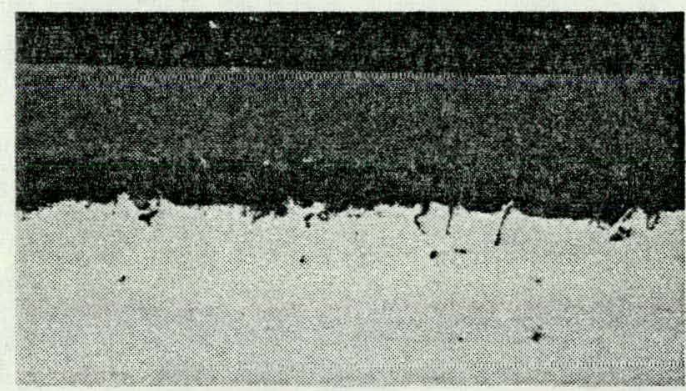

BEI
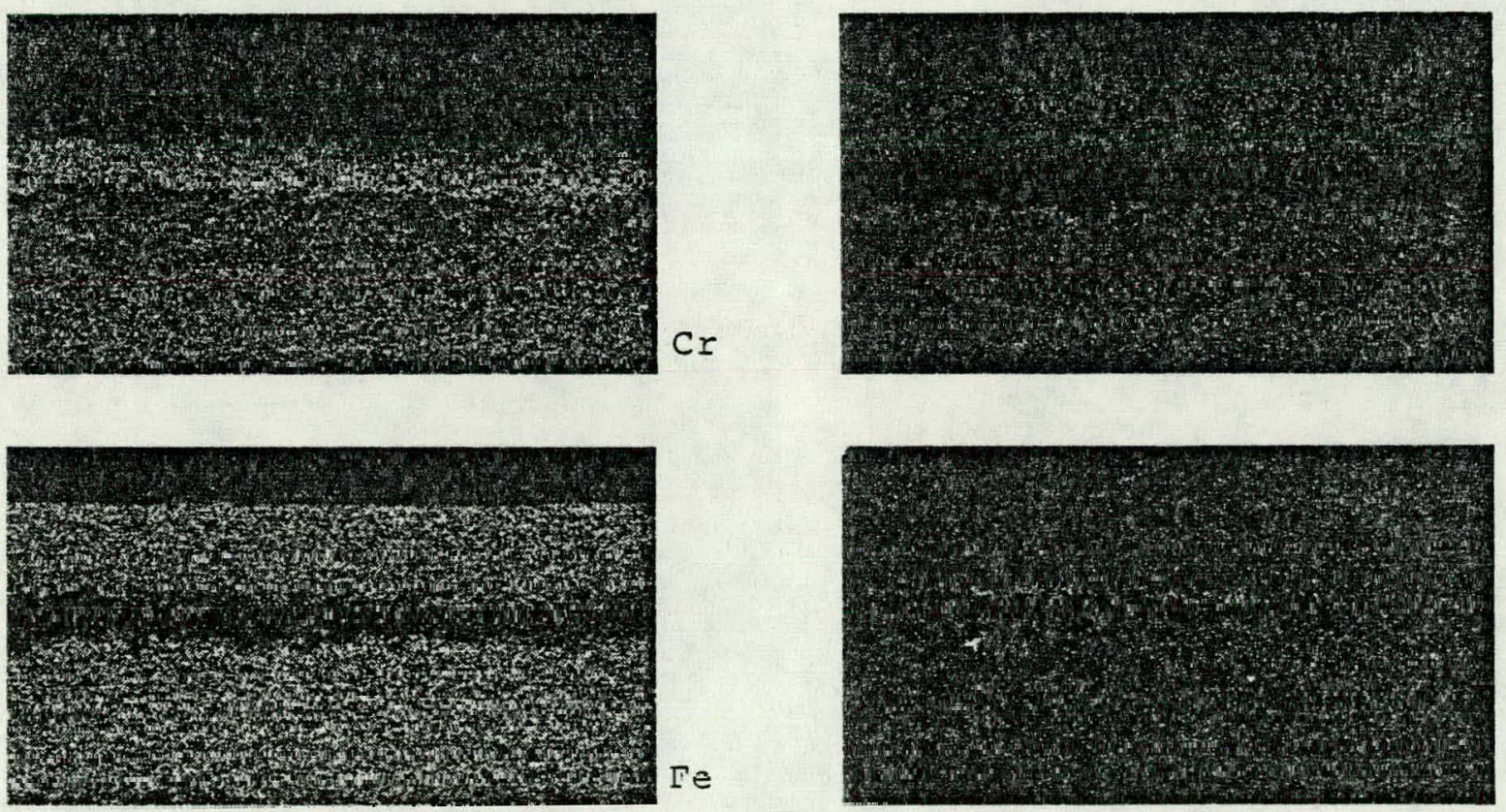

Figure 3-45. Backscatter Electron Image (BEI) and Elemental X-Ray Maps of the AISI 310 Control Specimen Tested for 1000 Hours at $760^{\circ} \mathrm{C}$ in a Molten Carbonate Environment Free of Halides 


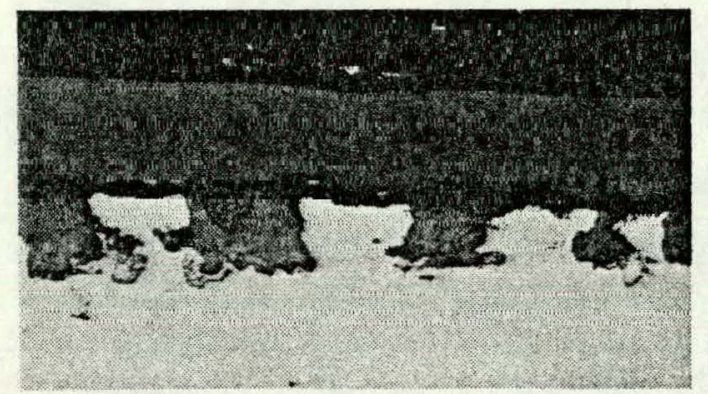

BEI
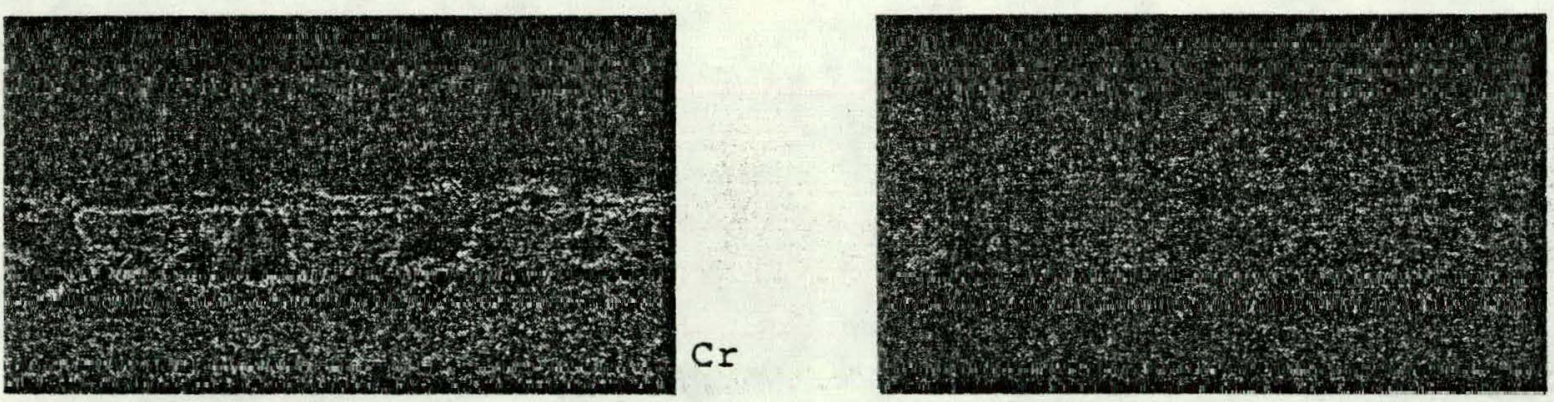

$\mathrm{Ni}$

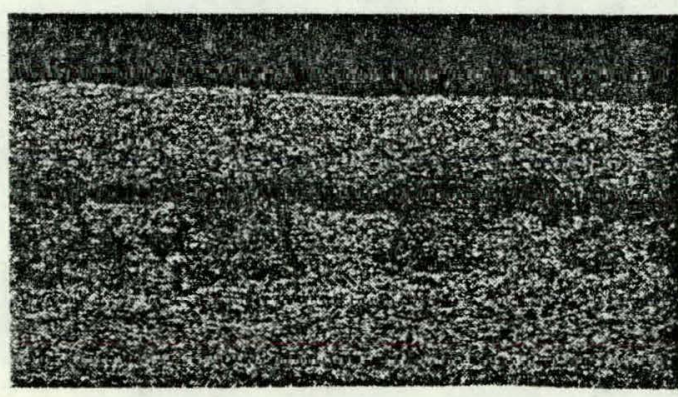

$\mathrm{Fe}$

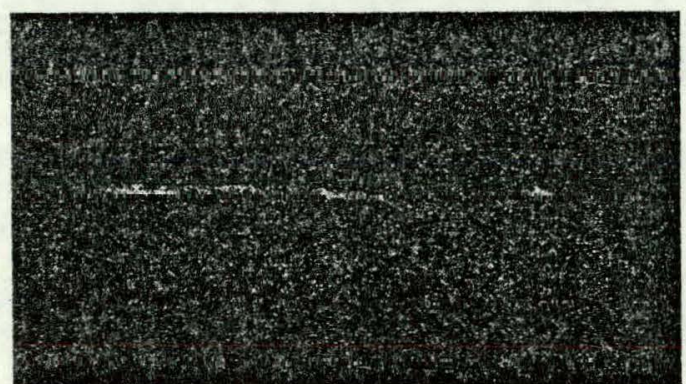

Si

Figure 3-46. Backscatter Electron Image (BEI) and Elemental X-Ray Maps of the AISI 310 Specimen Tested for 1000 Hours at $760^{\circ} \mathrm{C}$ in a Molten Carbonate Environment Containing $10 \mathrm{ppm} \mathrm{Cl}$ in the Oxidant Gas 

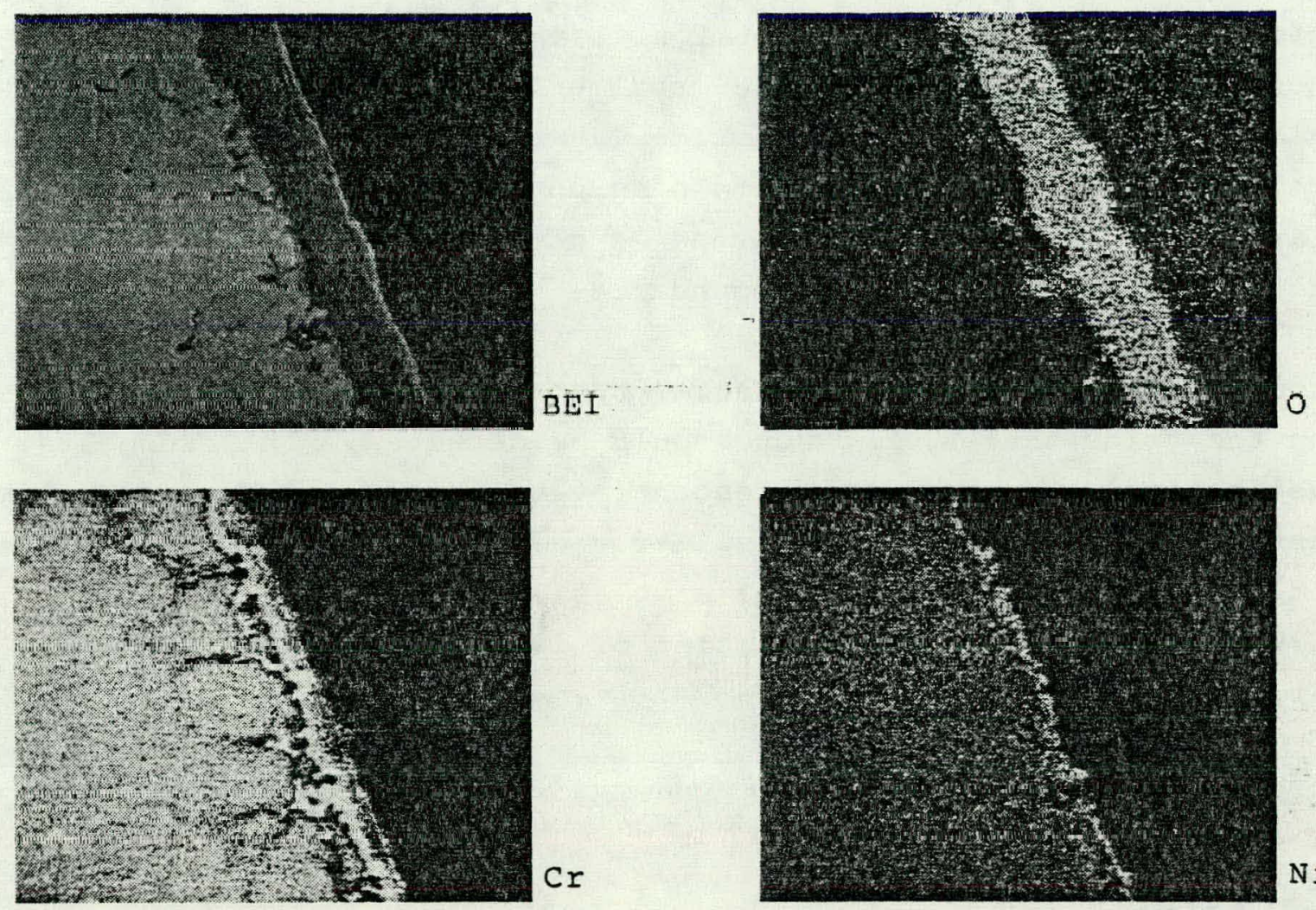

$\mathrm{Ni}$
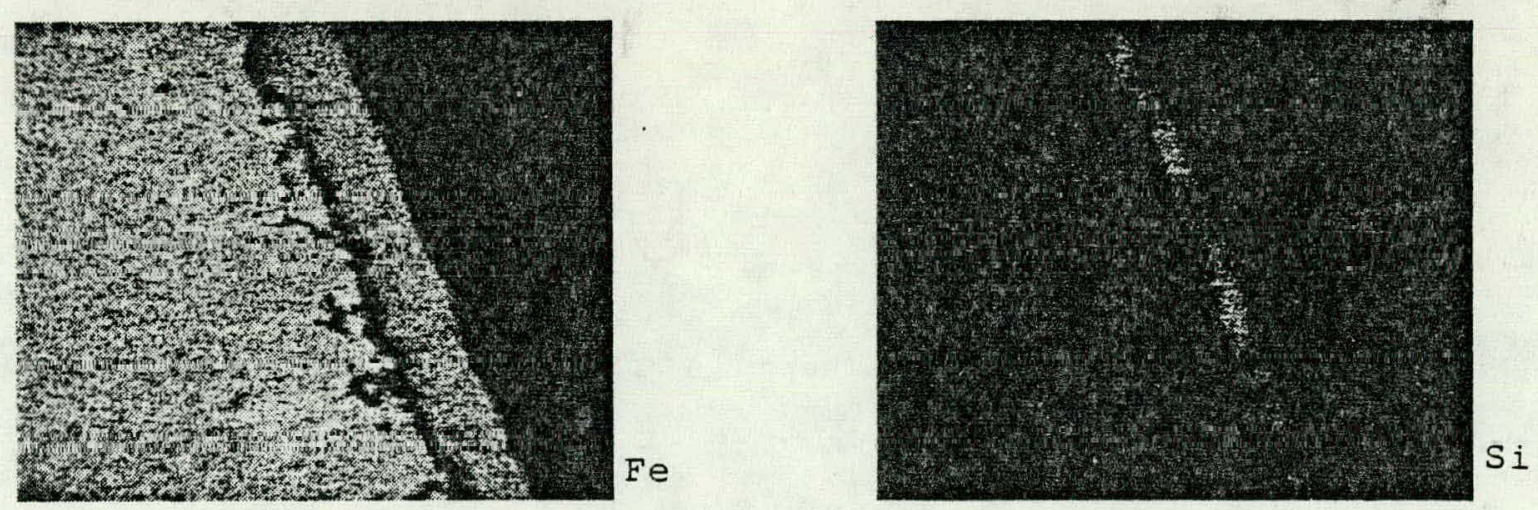

Figure 3-47. Backscatter Electron Image (BEI) and Elementa1 X-Ray Maps of the AISI 310 Specimen Tested for 1000 Hours at $1400^{\circ} \mathrm{F}$ in a Molten Carbonate Environment Containing $10 \mathrm{ppm} F$ in the oxidant Gas 
The Incoloy 825 control specimen, Figure 3-48, also shows the nickel and iron oxides in the outer layer and a continuous chromium-rich oxide underlayer. Upon exposure to the chloride-containing environment, Figure 3-49, the chromium-rich oxide layer became significantly thinner and extended into the grain boundaries of the base metal. Chromium depletion in the matrix underneath the chromium-rich oxide layer is also evident. The specimen exposed to the fluoride-containing environment, Figure 3-50, was similar in appearance, but the presence of chromium-rich oxide and depletion of chromium in the grain boundaries were also noted.

During the SEM and Microprobe analyses, a special effort was made to find halides in the oxide scales, but none could be detected. This suggests that either halides are present in concentrations below the detection limit of the instruments $(<1 \%)$ or that volatile halide corroson products were formed and evaporated. An example of a volatile corrosion product of this type is $\mathrm{CrO}_{2} \mathrm{Cl}_{2}$ which has a boiling point of $117^{\circ} \mathrm{C}$, well below the $760^{\circ} \mathrm{C}$ test temperature. 
Pages $65-67$ intentionally left blank 


\section{Conclusions}

Results of the corrosion tests indicate that the presence of a halide in a molten carbonate electrolyte accelerates the corrosion of AISI 316, AISI 310 , and Incoloy 825 alloys. In a halide-free and chloride-containing environment, the AISI 310 alloy was the most resistant of the three. However, in a fluoride-containing molten carbonate environment, the resistance to corrosion of AISI 310 was comparable to that of AISI 316 and somewhat lower than that of Incoloy 825 .

Metallographic and weight change data suggest that the halicles accelerate the corrosion of the alloys by detrimentally affecting the adherence of the protective scales. This is evidenced by more oxide spalling in samples tested in the halide-containing environments than in the control samples.

SEM/Microprobe analyses showed that the oxide scales formed on the three alloys were similar in composition. The resistance of the alloys to corrosion appeared to be related to the uniformity, continuity, and rompactnest of the chromium-rich oxide protestive laycr. Breakluwn of this layer resulted in increased corrosion. It should be pointed out that since no $X-R a y$ or Electron Diffraction analyses were conducted in this study, the specific make-up of the protective scales, i.e. whether spinels, mixed spinels, or metal oxides, could not be determined. In the presence of fluoride, the corrosive attack appeared to bc more intelyranular in nature for all three alloys. This is evidenced by the appeararice of the chromiumrich oxide phase in the outermost grain boundaries of the baee metal and by chromium depletion of the grain boundaries.

Although a spectal effort was made to find halides in the oxide scales, none could be detected. This suggested that either the halides were present in concentrations below the detection 1 imit of the instrument $(<1 \%)$ or that volatile corrosion products were formed and then lost by evaporation in the course of the test. The presence of voids in the oxide scales lends credence to the latter hypothesis. 
TASK 4 - IN-CELL INVESTIGATION

Experimental in-cell data on the effects of hydrogen chloride present in the fuel gas of a molten carbonate fuel cell were previously obtained by IFC under Contract DE-AC-01-79ET15440 with DOE. The experimental conditions and reactant compositions used in those tests are listed in

Table 4-1. Two different hydrogen: chloride contents were introduced into the fuel gas at atmospheric pressure, first $60 \mathrm{ppm}$ and then $10 \mathrm{ppm}$. Between the introduction of the $60 \mathrm{ppm}$ and the $10 \mathrm{ppm}$, the performance of the cell was allowed to recover. In these tests, the $\mathrm{HCl}$ was introduced in the fuel by adding the appropriate amount of $\mathrm{HCl}$ to the fuel-gas water saturator: 


\section{TABLE $4-1$}

EXPERIMENTAL CONDITIONS FOR PREVIOUS CHLORIDE TESTS* (CELL NO. 319)

Pressure $=1 \mathrm{~atm}$

Temperature $=650^{\circ} \mathrm{C}$

Fuel Composition:

51.0 mole $8 \mathrm{H}_{2}, 9.6$ mole $8 \mathrm{CO}, 10.6$ mole $8 \mathrm{CO}_{2}$ 28.8 mole $8 \mathrm{H}_{2} \mathrm{O}$

Oxidant Composition:

11.7 mole $8 \mathrm{O}_{2}, 17.1$ mole $8 \mathrm{CO}_{2}, 64.1$ mole \& $\mathrm{N}_{2}, 7.1$ mole y $\mathrm{H}_{2} \mathrm{O}$

Current Density $=172 \mathrm{ma} / \mathrm{cm}^{2}$

Fuel $\left(\mathrm{H}_{2}+\mathrm{CO}\right)$ Utilization $=81 \%$

Oxidant $\left(\mathrm{CO}_{2}\right)$ Utilization $=30 \%$

Fuel HCl Content $=10 \mathrm{ppm}$ and $60 \mathrm{ppm}$

*DOE Contract No. DE-AC01-79ET15440

$$
4-2
$$


The experimental cell voltage data at a constant current density of $172 \mathrm{~mA} / \mathrm{cm}^{2}$ after the introduction of the $\mathrm{HCl}$ into the fuel gas are presented as a function of time in Table 4-2 for $10 \mathrm{ppm} \mathrm{HCl}$ and Table 4-3 for $60 \mathrm{ppm} \mathrm{HCl}$. A graph of the data for these tests is presented in Figure 6-5.

$$
\text { TABLE } 4-2
$$

EXPERIMENTAL DATA FOR TEST ẆITH 10 PPM HCI IN FUEL

\section{TIME AFTER}

\section{CELL TIME}

(HRS)
HCI INTRODUCTION

(HRS)
CELL VOLTAGE

(VOLTS)
VOLTAGE DECAY

(VOLTS)

$\begin{array}{rccc}790 & 0 & 0.681 & 0 \\ 810 & 20 & 0.667 & 0.014 \\ 834 & 44 & 0.670 & 0.011 \\ 858 & 68 & 0.662 & 0.019 \\ 929 & 139 & 0.658 & 0.023 \\ 953 & 163 & 0.660 & 0.021 \\ 977 & 187 & 0.663 & 0.018 \\ 1001 & 211 & 0.651 & 0.030 \\ 1025 & 235 & 0.652 & 0.029 \\ 1097 & 307 & 0.630 & 0.051 \\ 1121 & 331 & 0.642 & 0.039 \\ 1145 & 355 & 0.643 & 0.038 \\ 1169 & 379 & 0.643 & 0.038 \\ 1193 & 403 & 0.643 & 0.038 \\ 1265 & 475 & 0.652 & 0.029 \\ 1288 & 498 & 0.639 & 0.042 \\ 1312 & 522 & 0.648 & 0.033\end{array}$


TABLE 4-3

EXPERIMENTAL DATA FOR TEST WITH 60 PPM HCI IN FUEL

TIME AFTER

CELL TIME

(HRS)

629
HCI INTRODUCTION

(HRS).
CELL VOLTAGE

(VOLTS)
VOLTAGE DECAY

(VUL'TS)

$\begin{array}{lc}0.678 & 0 \\ 0.675 & 0.003 \\ 0.623 & 0.055 \\ 0.597 & 0.081\end{array}$

0

0.16

1.83

10.25

0.597

0.081

The cell design used in this cell test was the same as that described previously under out-of-cell testing except that the rathode-side current collector consisted of a perforated plate and Kintex fabricated from AISI 316 stainless steel rather than single-piece 310 AISI stainless steel.

Additional in-cell tests were attempted under this contract as described in the Test Plan. Since elevated pressure operation was desired, the method of hallde introduction was changed from a halide solution in a gas saturator to bottles containing halide. Hydrogen and nitrogen were used as the carrier gases to introduce halides into the fuel and oxidant, respectively. Because of adsorption of reaction of the halides with the walls of the bottles during the time necessary to modify the test stands for the safe handing of the halide gases, no useful data were obtained with this injection system. 
TASK 5 - POST-TEST ANALYSIS

POST TEST OBSERVATIONS FROM HALF-CELL PERFORMANCE TESTS

\section{Experimental Procedure}

The half-cell performance tests are summarized in Table 3-2. After the completion of each half-ceil test, the cell chamber was flushed with an inert gas and allowed to cool. Most often, the cell was removed from the furnace while it was at about $650^{\circ} \mathrm{C}$ and allowed to cool rapidly under ambient conditions. The cell chamber was opened almost immediately after it was removed from the furnace and the cell holder placed on a stand to cool down to room temperature and then stored in a desicator containing a water absorbant.

After all the half-cell tests had been completed, visual observations were made of all the components tested. These observations included the condition of each component and the degree of contact between components. Thickness and resistivity measurements were also performed on cell components. Thickness was determined by using calipers whenever possible, or by breaking the sample in half, setting it on edge and comparing the thickness with a calibrated scale on the eyepiece of a microscope under $4 \mathrm{X}$ magnification. Errors between the two methods were less than 5 percent.

Resistivity was measured using the method of L. J. van der Pauw [22], summarized by J. I. Smith and J. R. Stapay [23]. The sample to be measured was sanded flat and its thickness, $d$, measured by calipers. The sample was then placed on a clean $7.5 \mathrm{~cm}$ diameter alumina plate. Four springloaded $0.038 \mathrm{~cm}$ diameter platinum wires were orientated so that the tips of the wires made contact with the edge of the sample, each wire tip as far apart from the other tips as possible. The platinum wires were held onto 
the alumina with new alligator clips, which were attached to silver wire leads. Current was first passed through two adjacent wires and the potential measured across the other two wires, and a resistance calculated, $R_{1}=$ $\mathrm{V}_{1} / I_{1}$. Then current was passed through two other adjacent wires, one of the wires being the same as that used to give $I_{1}$, and the potential across the remaining two wires measured. The second resistance, $R_{2}=$ $\mathrm{V}_{2} / I_{2}$ was then used with $R_{1}$ to determine the resistivity, $\rho$, by iteratively solving:

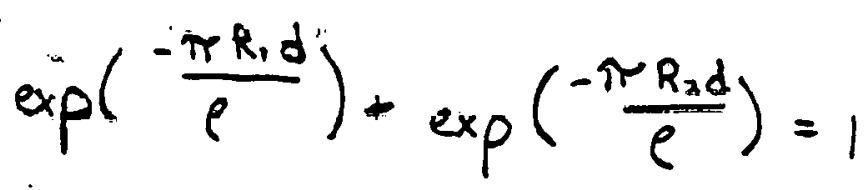

This method gave a resistivity of $0.00119 \Omega \mathrm{cm}$ for a graphite sheet (1iterature values range from $0.0010 \Omega \mathrm{cm}$ to $0.0019 \Omega \mathrm{cm}$ ).

Component conditions noted included the color, the degree of cracking, mechanical strength, hardness and any other unusual features. Hardness was determined by comparing the depth and ease in which a scratch could be made using a razor blade in the sample relative to new component. material not tested in the half-cell.

The degree of contact between components was determined by how easily components could be separated using a razor blade. Components that were separated when received were considered to have poor contact, unless one component left marks or indentations on the entire surface on the other, in which case contact was considered probably good. Components that were attached together when received but were not in full contact or took little effort to separate were considered to have poor contact. Samples that could not be separated at all or without a dedicated effort were considered to have good contact. 


\section{Thickness Measurements}

The results of the pre-test and post-test component thickness measurements are given in Table 5-1. Pre-test thicknesses were obtained on all matrices, all working electrodes, some of the counter electrodes, parts of the current collectors, but none of the fine pores. All pre-test components had relatively consistent thicknesses. The matrix used in cathode Test 6 consisted of three layers of tape, but would have fallen into the range of the other values if it had"only two layers. Post-test matrix thicknesses varied greatly, depending on the amount of compression placed on the tape before or during the test and on electrolyte on the surface of the tape, which may have interfered with the measurements. The tape and the working electrode in Cathode Test 3 could not be separated, so the cathode was subtracted away from the thickness of both cathode and tape to obtain the matrix thickness, and this may have introduced errors. Note that the active area matrix thicknesses are much smaller than either the wick area or pre-test thicknesses. This is probably a result of the method in which the three tests shown in Table 5-1 were assembled, where the working electrode was pressed into the tape. Matrix layer thicknesses were probably not significantly affected by the presence of halide in the electrolyte.

Pre-test working electrode thicknesses were very consistent. The counter electrodes used in Cathọde Tests 8 and 9 and Anode Tests 1,2 and 3 were of the same material as the working electrodes. 
TABLE 5-1 IIALF CELL POST-TEST OBSERVATIONS SUMMARY

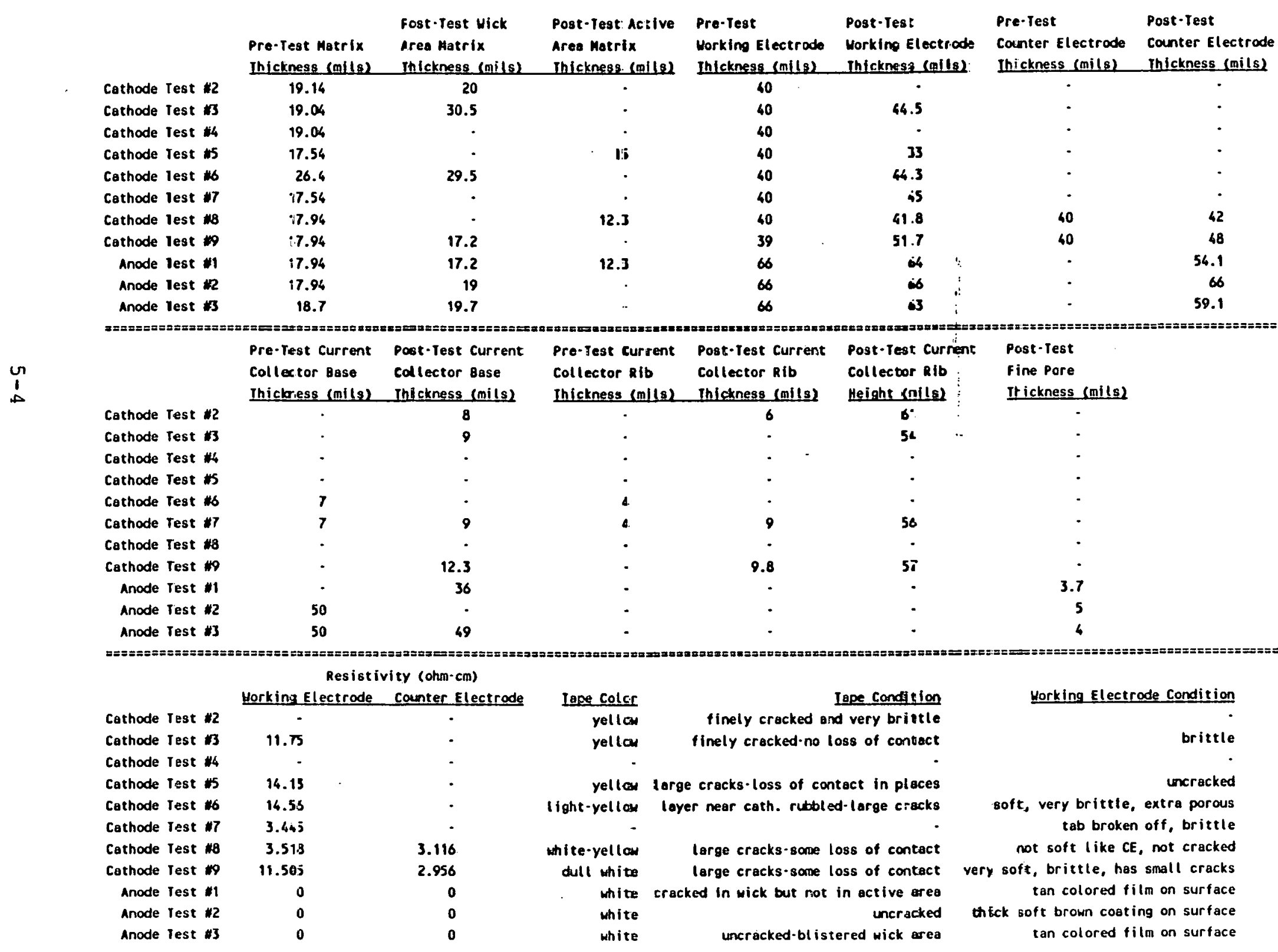


The anodes appear to have thinned slightly from testing, probably due to the external pressure applied to the cell package to ensure good contact between components. Halide did not seem to affect anode thicknesses greatly. The cathodes on the other hand thickened from testing, especially the fluoride test (Cathode Test 9) where both the working electrode and the counter electrode thicknesses increased significantly. The increase in thickness may have been due to electrolyte on the electrode surface, thus interfering with the thickness measurements. However ignoring Cathode Test 5 which lost thickness probably because of the assembly procedure, there is a weak correlation between the increase in thickness and the total operating time (Figure (5-1). Cathode compaction has been noted in molten

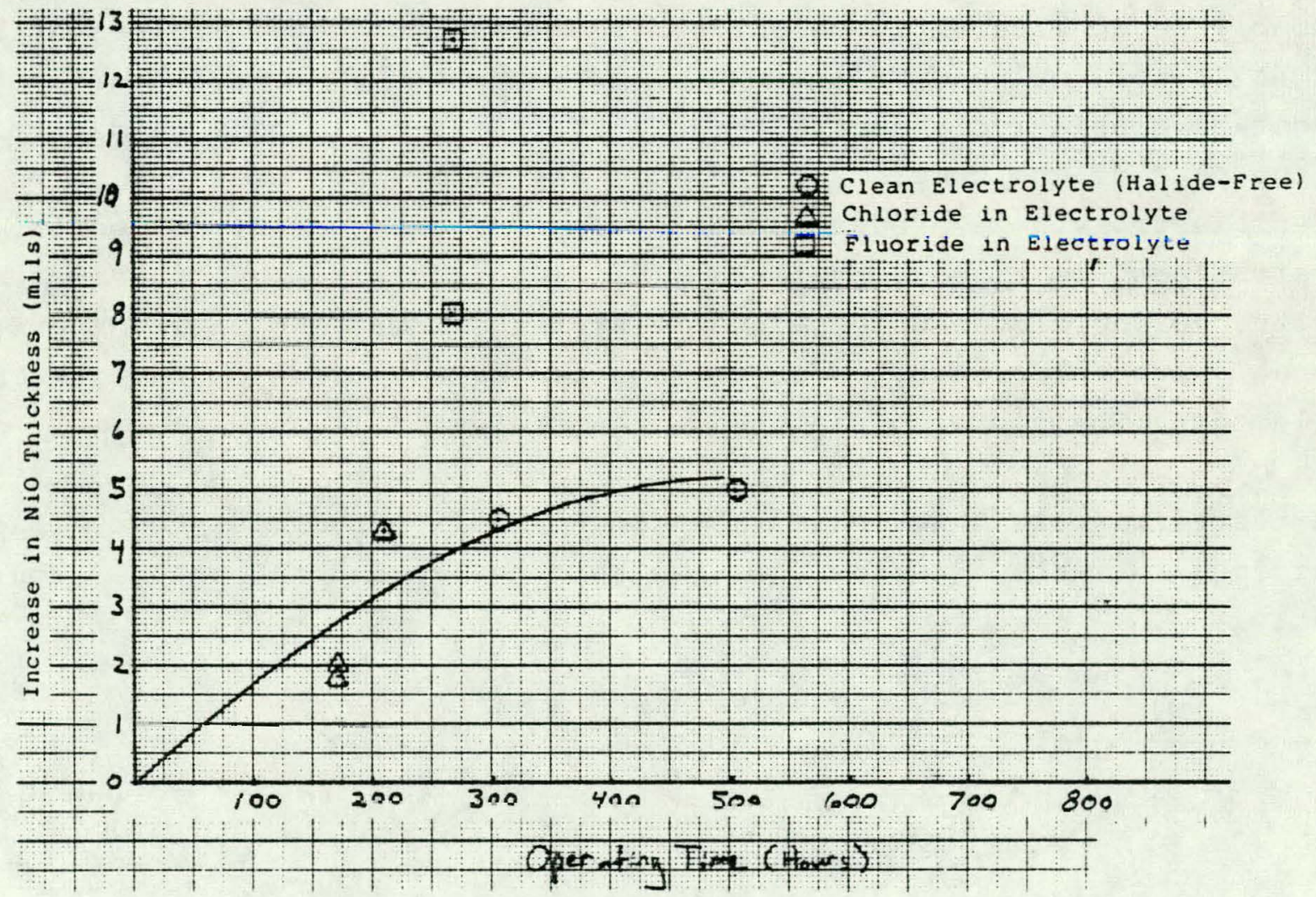

Figure 5-1. Effect of Fluoride on NiO Expansion 
carbonate stacks where swelling is restrained by externally applied pressure. The nickel cathodes swelled due to reactions with oxygen, lithium, and possibly halide. The cathodes normally convert to lithiated nickel oxide in the absence of halide. Fluoride appears to enter the nickel oxide lattice, or change the manner of nickel oxidation, while chloride did not, resulting in the Cathode Test 9 working and counter electrodes swelling more than those used in other tests. Fluoride entering the lattice structure is possible because the fluoride ion is about the same size as oxygen, while the chloride ion is larger (atomic radil: $F^{-}=1.36 \AA, \mathrm{Cl}^{-}=1.81 \AA, 0^{-2}=1.40 \AA$, $\left.\mathrm{Li}^{-}=0.60 \AA\right)$. In a situation where the expansion would be constrained, such as in a stack (or to some extent, in the half-cell), this would result in a decrease in the pornsity of the cathode and would affect electrolyte distribution in the cell.

Not a11 the pre-test current collector dimensions were recorded, but can probably be considered to be uniform from test to test. Pre-test rib height is not included in the table, but is about $59 \mathrm{mils}$. These results cannot be considered accurate because thickness could only be determined at the edge of the sample and the edge may or may not have had burrs. often electrolyte was found on the surface of the current collector. Nevertheless, it appears that the AISI 310 stainless steel shielded slot current collectors used in cathode tests have increased in thickness, probably due to electrolyte on the surface or corrosion of the current collector. The nickel plate used in Anode Test 3 is unchanged.

Pre-test fine pore thicknesses are about 4 mils. The post-test values indicated in Table 5-1 show that the thicknesses did not change significantly. 


\section{Resistivity}

Resistivity measurements were made on all lithiated nickel oxide components that were available. All nickel components used in the anode tests had immeasurably small resistivities. The working electrode used in Cathode Test 6 ( 3.1 anion percent chloride) has a high resistivity, relative to the other values in the table... Yet the working electrode in Cathode Test 8 (23 anion percent chloride) has a low resistivity, which is about equal to the resistivity of the Cathode Test 8 counter electrode. The Cathode Test 9 working electrode has a high resistivity, while its counter electrode has a low resistivity. The resistivity values may indicate how much lithium has entered the lattice. A low resistivity may indicate that the Nio was fully lithiated. This would explain why Cathode Test 7 , which ran the longest of any test and may have had sufficient time to lithiate, has a low resistivity. Lithium also enters the lattice more readily at high potentials. This might explain the difference in resistivity between the working and counter electrodes used in Cathode lest 9 . It is not understood why Cathode Test 6 has a high resistivity, while Cathode Test 8 has low resistivities in both the working and counter electrodes. It was hoped that the resistivity values would indicate whether or not halide had entered the lattice structure, but conclusions were difficult to draw from this set of data.

\section{Condition of Matrix}

Unfilled tape that has been heated to cell operating temperature of $650^{\circ} \mathrm{C}$ is brittle and white. Most of the matrices used in cathode tests ended with a yellow color. The yellow color is thought to be due to chromate $\left(\mathrm{CrO}_{4}{ }^{-2}\right)$ in the electrolyte. Chromium in the stainless steel components of the cathode side of a cell oxidizes and diffuses into the electrolyte. Chromium in the nickel anodes did not give the electrolyte a yellow 
color because of the reducing atmosphere in the anode half-cell chamber and the method of anode fabrication. However, the cathode tests that had halide in the electrolyte did not have as deep a yellow color in the matrix as those that ran with halide-free electrolyte. The chloride cathode tests (Tests 6 and 8 ) had matrices that had a yellow tint, with the tint lighter in the test having more chloride in the electrolyte. The fluoride cathode test (Test 9) had a matrix that showed hardly any yellow coloring. The most likely reason for the lack of yellow coloring in the matrix in the presence of halide is that the chromate ion reacted with the halide, forming a volatile compound (for example, $\mathrm{CrO}_{2} \mathrm{Cl}_{2}$, which has a boiling point (117C) that is much less than oell operating teinjerature). 'lihis is because all chromium compounds have some color with the exception of $\mathrm{CrCl}_{2}$ ' which is white. If this compound was formed, then CrF ${ }_{2}$, which is green, would have been expected to form in the fluoride test, and this color would be seen on the white matrix. Other explanations include a change in the oxidation state of chromium or the formation of a passivation layer impermeable to oxygen or chromate ion.

The matrices themselves were almost always found to have some cracks and were very brittle. This would probably be due to the method of cell assembly, the electrolyte removals during the test, or the cooling duwn process. Tape layer cracking was especially profound in Cathode Test 6 . In Test 6 , the layer of tape nearest the cathode was severely cracked or broken up, looking more like large grains of sand rather than a layor of fine particles. However, the same thing was not observed in rathode Teet 5 , which was assembled in a similar fashion, or was it observed in any of the other halide tests leading to the conclusion that the layer was broken up because three tape layers were used in the configuration, instead of two.

The wick area of the matrix used in Anode Test 3 (23 anion percent fluoride in the electrolytel had several large blisters. These blisters were easily broken to reveal several small air pockets, either partially or wholly en- 
closed by white material. It is possible that these blisters were undistributed electrolyte.

\section{Condition of Working Electrode}

All the cathodes used in the half-cell tests were made brittle through use in the half-cell. Some cathodes contained small cracks which may have developed outside the Iest $7 .$. :except the tab used in Cathode Test 7 , used for electrolyte removal, which broke off during the test. The cathodes used in the halide tests (Cathode Tests 6, 8, 9) were soft in comparison to those tests which ran without halide in the electrolyte. This softness was determined by noting how easily a sample could be $;$ scratched with a scalpel. The Nio in the halide test cathodes did not flake away like the $\mathrm{N} 10$ in the clean electrolyte test cathodes when scratched. This soft layer was fairly thick, but did not go all the way through the cathode because the cathodes in the halide tests were just as brittle as the cathodes in the rest of the tests. The soft layer may be similar to the loss of adherence of particles observed in the General Electric full cell tests having chloride in the oxidant.

The anodes, unlike the cathodes, retained their original mechanical strength. A soft tan-colored film developed on the surface of all the anodes, even the anode used in the baseline cell. This film was found to be much thicker in Anode Test 2, the chloride test. It is possible that chromium in the anode may have reacted with an impurity present in all cells, possibly chloride, resulting in the soft tan layer.

\section{counter Electrode Condition}

Wherever a nickel counter electrode was used in a half-cell configuration, rather than a gold counter electrode, the counter electrode was observed in the same condition as the working electrode (see Table 5-2). The only exception is that in cathode Test 8 where the counter electrode was softer than the working electrode. 
TABLE 5-2 HALF CELL POST-TEST OBSERVATIONS SUMMARY

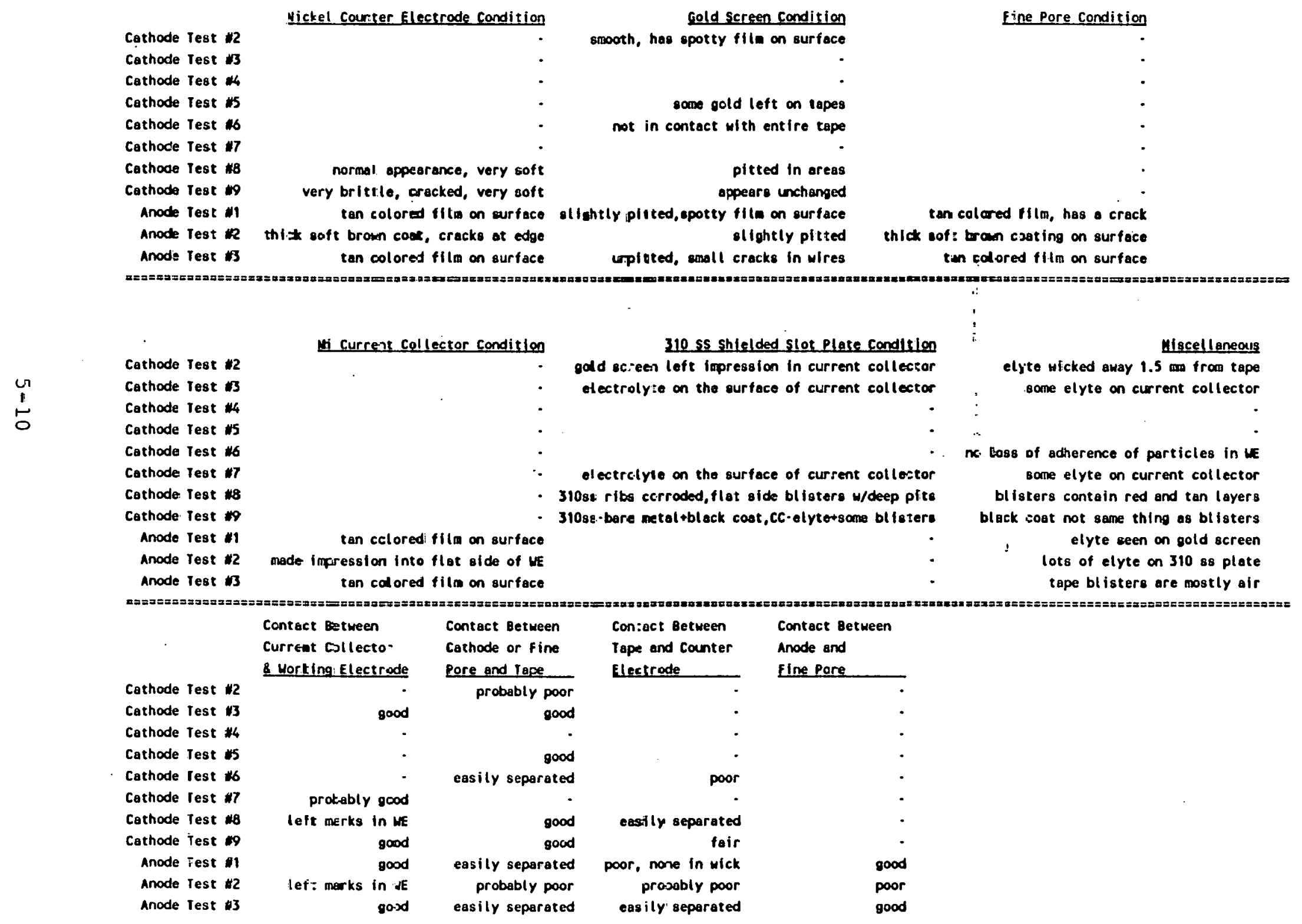




\section{Fine Pore Condition}

The fine pores in all the anode tests were in the same condition as the corresponding working electrode and counter electrode.

\section{Gold Screen Condition}

The gold wire screen was used as the counter electrode in Cathode Tests 2-7 and was used to connect the counter electrode to out-of-cell electronic equipment in Cathode Tests 8,9 and Anode Tests 1-3. In cases where the gold screen was used as a counter electrode, a gold film was often found on the matrix in places where the gold contacted the matrix. Some electrolyte was found on all the gold screens observed, which appeared as a spotty film. Some of the screens were pitted, which is not necessarily due to the presence of halide, since Anode Test 1 (baseline test) had a pitted gold screen. The gold screens used in the fluoride anode and cathode tests, however, appeared unchanged.

\section{Nickel Current Collector Condition}

The niskel current collectors in the anode tests (see Table 5-2) were in the same condition as the corresponding working electrode and counter electrode.

\section{Stainless steel Current Collector Condition}

The AISI. 310 stainless steel shielded slot plates were used in cathode tests both as current collectors and as a method of allowing gases to escape from the counter electrode. In some tests both plates were not available for post-test observations. The most significant observations 
were made on the plates used in Cathode Tests 8 and 9 (23 anion percent chloride and fluoride in the electrolyte, respectively).

In Cathode Test 8, the current collector was not available but the AISI 310 stainless steel plate under the counter electrode was. The flat side of the plate (which was next to the counter electrode) was covercd with a shiny black brittle material that was easily scraped away. Underneath it was a tan-colored layer: underneath which was a rcd-brown colored layer, underneath which was what appeared to be bare metal. Some areas had large blisters, which when scraped away, revealed a great deal of the red-brown material and deep pitting. The blisters were located where the plate made contact with the counter elertrode, in some arcao counter electrude llaterial was found attached to the blisters. The ribbed side of the plate did not have the blisters, but still had the shiny black material and was covered with electrolyte.

Both the current collector and the plate under the counter electrode from Cathode Test 9 were available for post-test analysis. Bare metal was seen on both parts. The plate under the counter electrode had areas covered with the same shiny black material found on the cathode Test 8 plate but no blisters were found. The shiny black material was difficult to scrape away, but where it could be done, tan material and deep pitting were found. In some areas on the ribbed side, gray-silver blisters were found, but these were mostly air pockets that were easily flaked away. Underneath the air pockets was a thin brown layer. The current collector's flat side (facing the working electrode) had a few of the blisters that were noted on the Cathode Test 8 plate. The ribbed side was covered with electrolyte, but no blisters or tan material was found.

\section{Contact Between Components}

In all cases the contact between the current collector and the working 
electrode was good. On the other hand, contact between the working electrode (or fine pore) and the matrix was only good in the cathode tests where special steps were taken to ensure good contact. In Cathode Test 3 , $\mathrm{LiAlO}_{2}$ powder was applied between the tape and the working electrode, which gave good contact. In Cathode Tests 5 and 6 , the tape was softened with isopropanol and the working electrode was pressed into the tape.

Cathode Test 5 had good contact between the two components but Cathode Test 6 did not, probably because of the broken up third layer. Hot pressing the matrix and working electrode together resulted in good matrix-working electrode contact in the case of Cathode Tests 8 and 9 , but did not in the case of the anode tests. The fine pores were easily separated from the matrix. Contact between the matrix and the counter electrodes was generally poor. The gold screen in Cathode Test 6 was not in contact with the entire tape, while the nickel counter electrodes and tapes were easily separated. Contact between the anode fine pores and working electrodes were good except in the case of Anode Test 2 where the ribbed side of the anode was facing the fine pore, giving less than 50 percent contact. Contact between components did not seem to be affected by the presence of halide in the electrolyte.

\section{Conclusions}

Chloride and fluoride in the electrolyte affected both anode and cathode half-cell components in several ways. The most significant effect was the corrosion and spalling of the cathode side stainless steel in the presence of chloride. A similar effect was observed to be not as pronounced in the presence of fluoride. This visually observed effect differs from the corrosion experiments which found fluoride to be more agressive than chloride in corroding AISI 310 stainless steel. This is explained by the way the two experiments were conducted. The corrosion experiments were conducted at a higher temperature for a much longer period of time, under a much lower halide concentration than the half-cell experiments. Fluoride 
may or may not be more aggressive than chloride in the half-cell experiment environment. Observations made on the half-cell components were not as rigorous as those made on the corrosion test specimens; the half-cell observations may have missed the development of an oxide layer or a change in mass of a component from corrosion and spalling. The half-cell tests showed that stainless steel is strongly attacked by halide; the corrosion tests quantified these observatons, but at diffferent conditions.

A potentially significant effect was observed in the case of nickel oxide in the presence of fluoride. In this case, the nickel oxide swelled in thickness twice as much as in any other test, even those having chloride in the electrolyte. The fluoride may have affected the oxidation and lithiation of the nickel, and the fluoride itself may have entered the lattice structure of the Nio. Under external component compression, this could lead to a denser cathode, changing how the electrolyte is distributed throughout a cell.

other important halide effects included an interaction between the chromium in the stainless steel and halides, and softening of the nickel oxide components. 


\section{TASK 6 - MODEL DEVELOPMENT}

Based on the literature survey, thermodynamic analyses, and experimental results, halides can affect the performance of molten carbonate fuel cells in several ways. The performance of each component, anode, cathode, and matrix, can be affected, and an electrolyte concentration polarization can occur due to different halide ion concentrations in the anode and cathode. These results were used to develop a model of the performance decay of molten carbonate fuel cells, in. the presence of halides. The electrolyte composition difference between the electrodes is described first because it affects the concentrations within the anode, cathode, and matrix and hence their performances as well.

\section{Electrolyte Concentation Polarization}

Halide present in a molten carbonate electrolyte migrates between the electrodes due to three effects: diffusion, ionic transference, and bulk flow. In equation form, the flux from the cathode toward the anode is: $i$

$$
\dot{M}=-D \frac{d c}{d x}+c w \frac{d \phi}{d x}+c V
$$

where the symbols are defined in the Table of Nomenclature. It a higher halide ion concentration is present on the anode side than the cathode side of a cell, the first term on the right represents the diffusion of halide toward the cathode as expressed by Fick's first law. The second term represents the flux of halide ion toward the anode due to the potential gradient in the electrolyte and the negative charge on the halide ion. The third term represents the bulk flow of halide ion toward the anode since the flux of carbonate ions across the cell when current flows results in a net bulk velocity in the electrolyte [24]. 
Since the rate at which halide enters and leaves cells is very low in the ppm range, this equation can be used to calculate a pseudo steady state concentration profile by assuming that the flux across the cell is zero. A true steady state is not achieved because of the loss of electrolyte with time. Equation $(6-1)$ becomes:

$$
\frac{d c}{C}=\frac{W}{D} d \phi+\frac{V}{D} d x
$$

The potential difterence across the cell, $\Delta \phi$, is equal to the matrix IR plus an IR contribution within the electrodes. The velocity of the clcctrolyte is dependent on the current using Faraday's law [24]:

$$
V=\frac{30(I / A)}{96,500 p}
$$

Using these relationships,

$$
\ln \frac{C_{A}}{C_{C}}=\frac{W I R}{D}+\frac{S}{D}\left(\frac{30(I / A)}{96,500 p}\right)
$$

For an $18 \mathrm{mil}$ matrix, $\delta=0.018(2.54 \mathrm{~cm}$.$) For a porosity of .042$, a tortuosity $=$ (porosity) -0.5 from the Bruggeman equation [25], an assumed diffusion coefficient of $10^{-5} \mathrm{~cm}^{2} / \mathrm{sec}$ and an elestrolyte deneity of $1.93 \mathrm{~g} / \mathrm{cc}$, the last term on the right becomes

$$
\frac{0.018(2.54)}{\left(10^{-5}\right)(0.42)^{1.5}} \times \frac{30(I / A)}{96.500(1.93)}=2.70\left(\frac{I}{A}\right)
$$


for the contribution from the matrix. If a lumped parameter analysis is considered, contributions from the anode and cathode to this term can be estimated by dividing the total possible contribution from each by two. This assumes that the electrochemical formation or consumption of carbonate ions occurs in the center of each electrode. These terms are (for a $40 \mathrm{mil}$ cathode of 0.75 porosity with an electrolyte content of 30 percent and a $56 \mathrm{mil}$ anode with a 0.42 porosity and an electrolyte content of 30 percent)

$$
\left[\frac{1}{2} \frac{(0.040)(2.54)}{[(0.75)(0.30)]^{1.5}}+\frac{1}{2} \frac{(0.056 \times 2.56)}{[0.42 \times 0.30)]^{1.5}}\right] \frac{30(I / A)}{96,500(1.93)\left(10^{-5}\right)}
$$

The total last term is therefore

\section{$35.9\left(\frac{I}{A}\right)$}

The two expressions in (6-6) are more significant than that in (6-5) because the velocities in the electrodes are higher than in the matrix.

The first term on the right of Equation (6-4) can be estimated if the mobility of the chloride is considered to be related to that of the carbonate ion by the ratio of the charge on the ion to its ionic radius [26].

From the conductivity of the carbonate, the carbonate ion mobility is $1.17 \times 10^{-5} \mathrm{~cm}^{2} /$ volt sec. The ratio of the charge to ionic radius of the carbonate is 0.67 , and for the chloride, 0.552 . The chloride mobility is then $0.96 \times 10^{-5} \mathrm{~cm}^{2} /$ volt sec. Using an iR of $20 \mathrm{mV}$ at $100 \mathrm{~mA} / \mathrm{cm}^{2}$ and a diffusion coefficient of $10^{-5} \mathrm{~cm}^{2} / \mathrm{sec}$,

$$
\frac{W I R}{D}=0.30\left(\frac{I}{A}\right)
$$


Since this term is much less than (6-5), ionic transference can be seen to be negligible.

Substituting the sum of $(6-5),(6-6)$, and $(6-7)$ into Equation $(6-4)$,

$$
\ln \frac{C_{A}}{C_{C}}=36.2\left(\frac{I}{A}\right)
$$

The differences in open circuit potential between two electrodes in electrnlyte of different halide concentrations were measured in this program and are shown in Figure 6-1. That data can be fit by the equation

or

$$
\begin{aligned}
& n_{\text {CONC }}=0.060 \ln \frac{C_{\text {CARB }}}{C_{\text {CARB A }}} \\
& n_{\text {Cowe }}=0.060 \ln \left(\frac{1-C_{C}}{1-C_{A}}\right)
\end{aligned}
$$

Eliminating $C_{c}$ between Equations $(6-8)$ and $(6-10)$

$$
n_{\text {cove }}=0.060 \ln \left(\frac{1-C_{A} e^{-36.2(I / A)}}{1-C_{A}}\right)
$$

The large exponent of 36.2 indicates that during operation on load, the cathode will be essentially free of halide and all of the halide will be located on the anode side. This means that halide will leave the cell only in the fuel effluent and $C_{A}$, the concentration of halide in the electrolyte at the anode will be directly dependent on the concentration of halide in the fuel exit gas. The variation of $C_{A}$ over the surface of the electrode area is assumed to be relatively small at steady state. This result is different from the assumption used in the estimation of electrolyte equilibrium composition in Task 1 that the halide will leave in the oxidant effluent. 


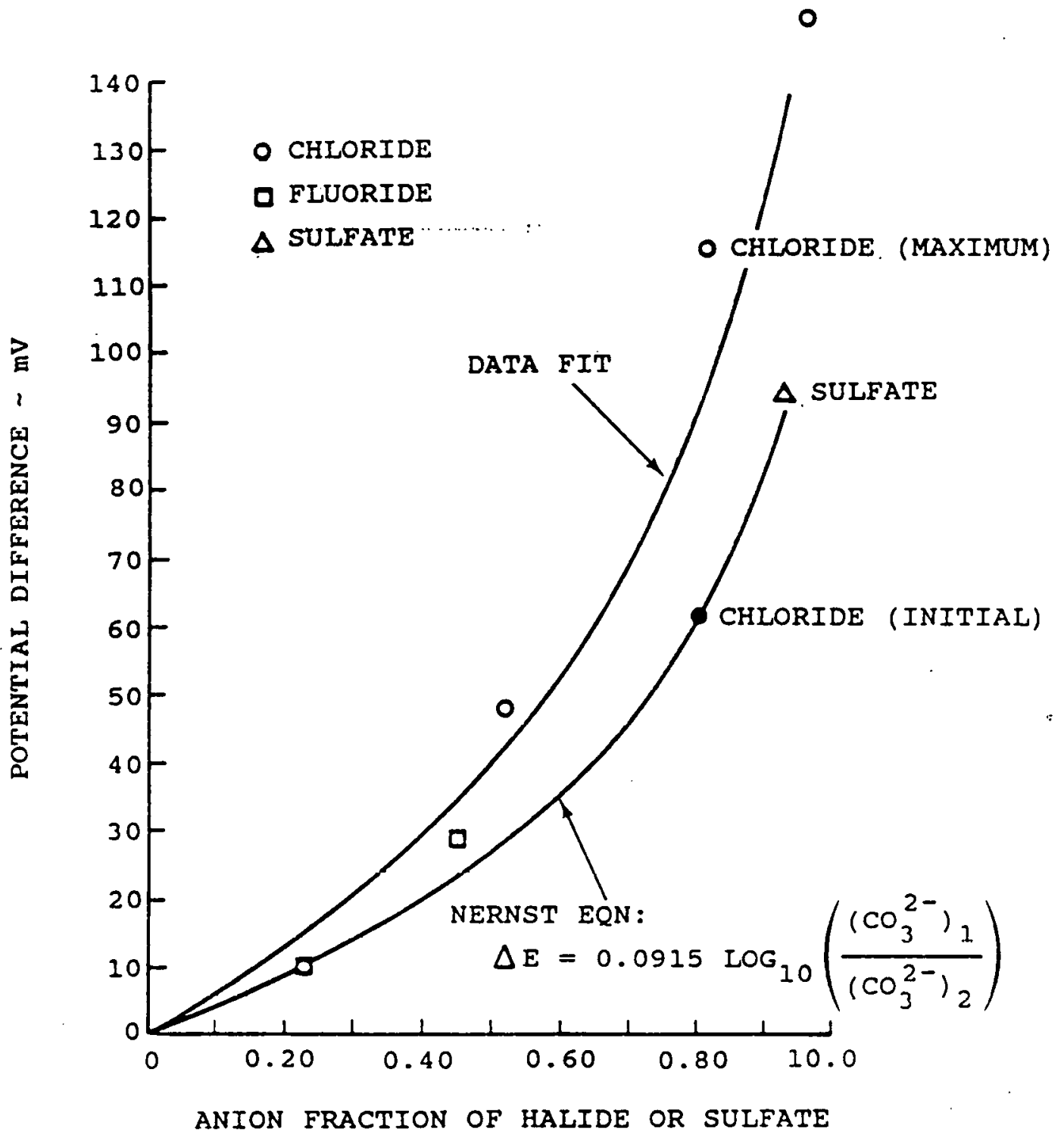

Figure 6-1. Potential Difference Due To

Difference in Electrolyte Composition 
The relationship between the gas- and liquid-phase concentrations (vapor pressures) were calculated in this program and are presented in Figure 6-2. These graphs were curve fit by the equations:

$$
C_{A C 2}=923.43 \operatorname{Exp}\left[-10.199\left(10 \times 10^{6}\right)^{-0.09212}\right]
$$

for chloride where LO is the mole fraction of chloride in the fuel effluent and

$$
C_{A_{F}}=1.8178-1.8173 \operatorname{Exp}\left[-0.3442\left(F 0 \times 10^{6}\right)\right]
$$

for fluoride where $F O$ is the mole fraction of fluoride in the fuel effluent.

The steady-state concentrations of chloride and fluoride in the fuel effluent can be calculated from the inlet concentrations in the fuel and oxidant if the concentration in the oxidant exhaust is assumed to be negligibly small. The resulting equations are:

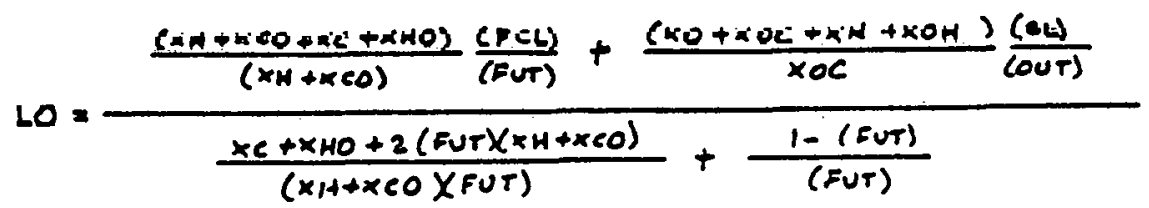

and

$$
F O=\frac{\frac{(X H+X C O+X C+X H O)}{(X H+X C O)} \frac{(P F)}{(E U T)}+\frac{(X O+X O C+X N+X O H)}{X O C} \frac{(F)}{(O U T)}}{\frac{x C+X H O+2(F U T)(X H+X C O)}{(X H+X C O X F U T)}+\frac{1-(F U T)}{(F U T)}}
$$

Prior to steady state being reached, a different relationship than that used in Equations $(6-11),(6-12),(6-13),(6-14)$, and $(6-15)$ must be uscd. If ill of the halide is assumed to be stored in the anode, the anion fraction of the halide in the anode will build up with time during an initial transient period. The initial moles of carbonate in the anode is

$$
\frac{0.01792 \mathrm{~g}(1.93 \mathrm{~s} / \mathrm{Cc})}{91.89 \mathrm{~g} / \mathrm{mole}}=3.76 \times 10^{-4} \frac{\text { moles }}{\mathrm{cm}^{3}}
$$




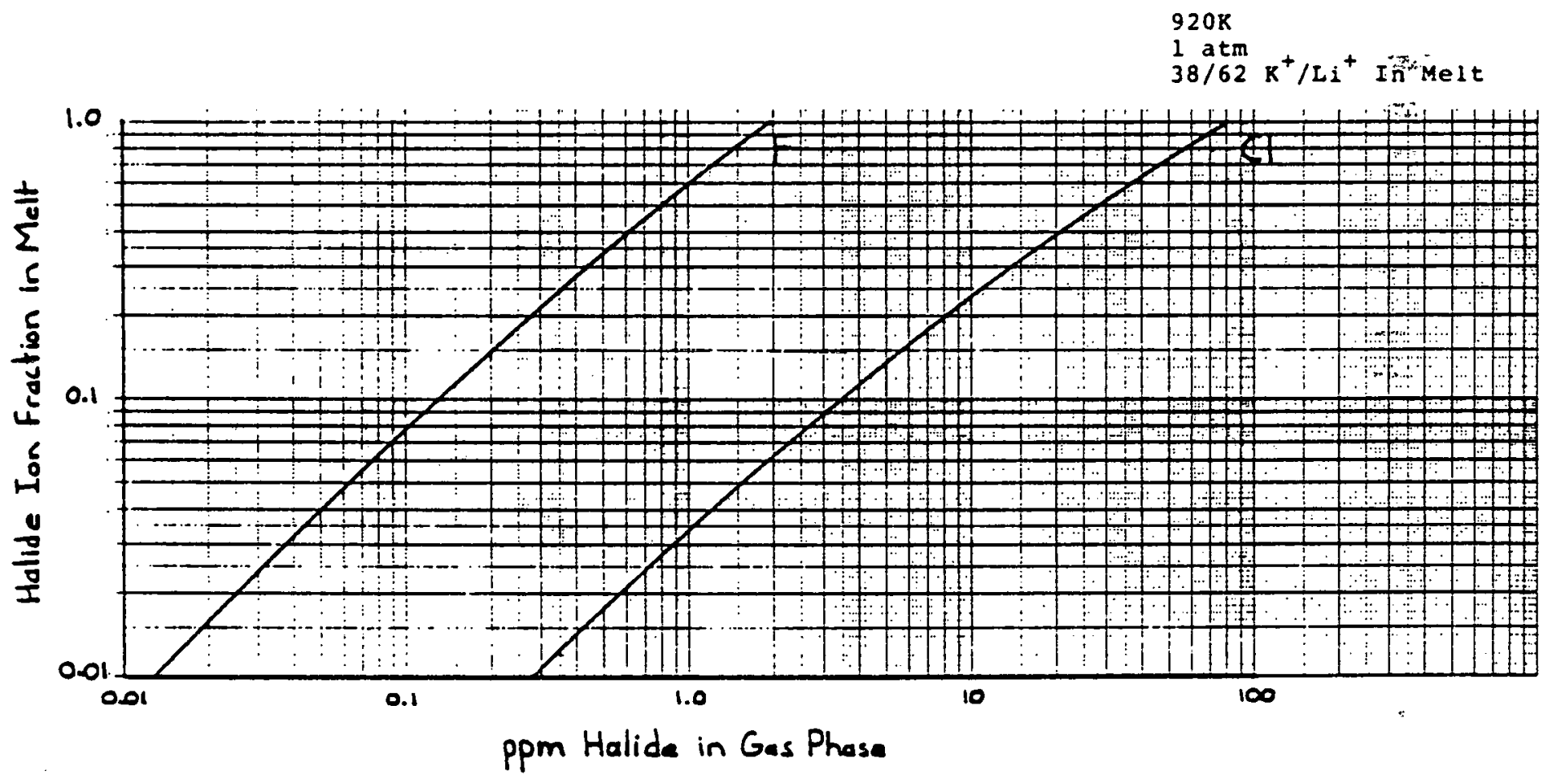

Figure 6-2. Calculated Vapor Pressures of Halides 
Some fraction of this ( $z$ ) may be present in thin films which will react with the halide and introduce concentration polarizations before the entire anode reaches steady-state. The moles of chloride from the fuel increases with time as:

$$
(M F C)=\frac{2(x A)(3600)}{F}\left(\frac{x H+x C O+x C+X H O}{x H+x C O}\right) \frac{(P C L)}{(F U T)} \cdot T
$$

The moles of fluoride from the fuel increases as:

$$
(M F F)=\frac{2(F h)(3600)}{F}\left(\frac{x H+x C O+x C+x H O}{x H+x C O}\right) \frac{(P F)}{(F U T)} T \quad(6-18)
$$

Similarly for the oxidant gas, the moles of chloride from the oxidant is:

$$
-(M O C)=\frac{2(I A)(3600)}{F} \cdot\left(\frac{x O+\times O C+X N+X O H}{\times O C}\right) \frac{(C L)}{(O N T)} T \quad(6-19)
$$

and for fluoride:

$$
(M O F)=\frac{2(\not A \times 3600)}{F}\left(\frac{x O+\times O C+X N+\times O H}{\times O C}\right) \frac{(F)}{(O U T)} T
$$

The concentration polarization for chloride is then, from Equation $(6-10)$ :

$$
\eta_{\text {CANCR }}=0.060 \ln \left[\frac{1}{1-\frac{(\mathrm{MFC})}{2\left(3.76 \times 10^{-4}\right)}-\frac{(\mathrm{MOC})}{z\left(3.76 \times 10^{-4}\right)}}\right]
$$

and for fluoride is:

$$
{ }_{\text {FUNRDE }}=0.060 \ln \left[\frac{1}{1-\frac{(M F F)}{z\left(3.76 \times 10^{-4}\right)}-\frac{(\text { MOF })}{2\left(3.76 \times 10^{-4}\right)}}\right]
$$

In this transient analysis, assumptions are made that all of the halide is stored in a fraction of the electrolyte in the anode, and that no halide leaves the cell during the transient period. The first assurntion will affect the length of the transient time and must be verified using experi- 
mental data. The second assumption is based on the probable manner in which the halide will be scrubbed from the reactant gases by the cell. The high effectiveness of the cell as a scrubber will probably result in halide in the fuel being removed near the fuel flow inlet, with little appearing in the fuel exhaust until breakthrough occurs. The case is not as simple with the cathode reactant and a crossflow configuration, but, with a lumped parameter analysis, this assumption is considered to be better than the assumption of uniform composition used in a homogeneous reactor model.

The concentration polarizations from Equations (6-21) and (6-22) are used until they exceed the values calculated from the steady-state Equations $(6-11),(6-12),(6-13),(6-14)$, and $(6-15)$. Then the steady-state equations are used.

\section{Anode Polarization}

Halides can affect the performance of anodes in three ways: loss of electrolyte from the anode, reduction in the anode kinetics for the $\mathrm{H}_{2}$ oxidation reaction at the inlet hydrogen pressure, and an increase in the utilization loss due to increased sensitivity to hydrogen pressure.

Experimental half-cell anode overpotential data previously obtained at $160 \mathrm{~mA} / \mathrm{cm}^{2}$ for a ribbed anode and fine pore are shown as a function of electrolyte percent fill in Figure 6-3. Points from the data graph are tabulated in Table $6-1$ and are used to obtain a functional relationship for anode polarization.

$$
3_{0}=f\left(M_{A}\right)
$$

where MA is the mass of the electrolyte in the anode per unit frontal area. Linear interpolation is used to obtain values of polarization at values of MA between those listed in Table 6-1. This mass can be obtained from the total mass of electrolyte in the cell, assuming that the capillary pore radius in each component is the same, 


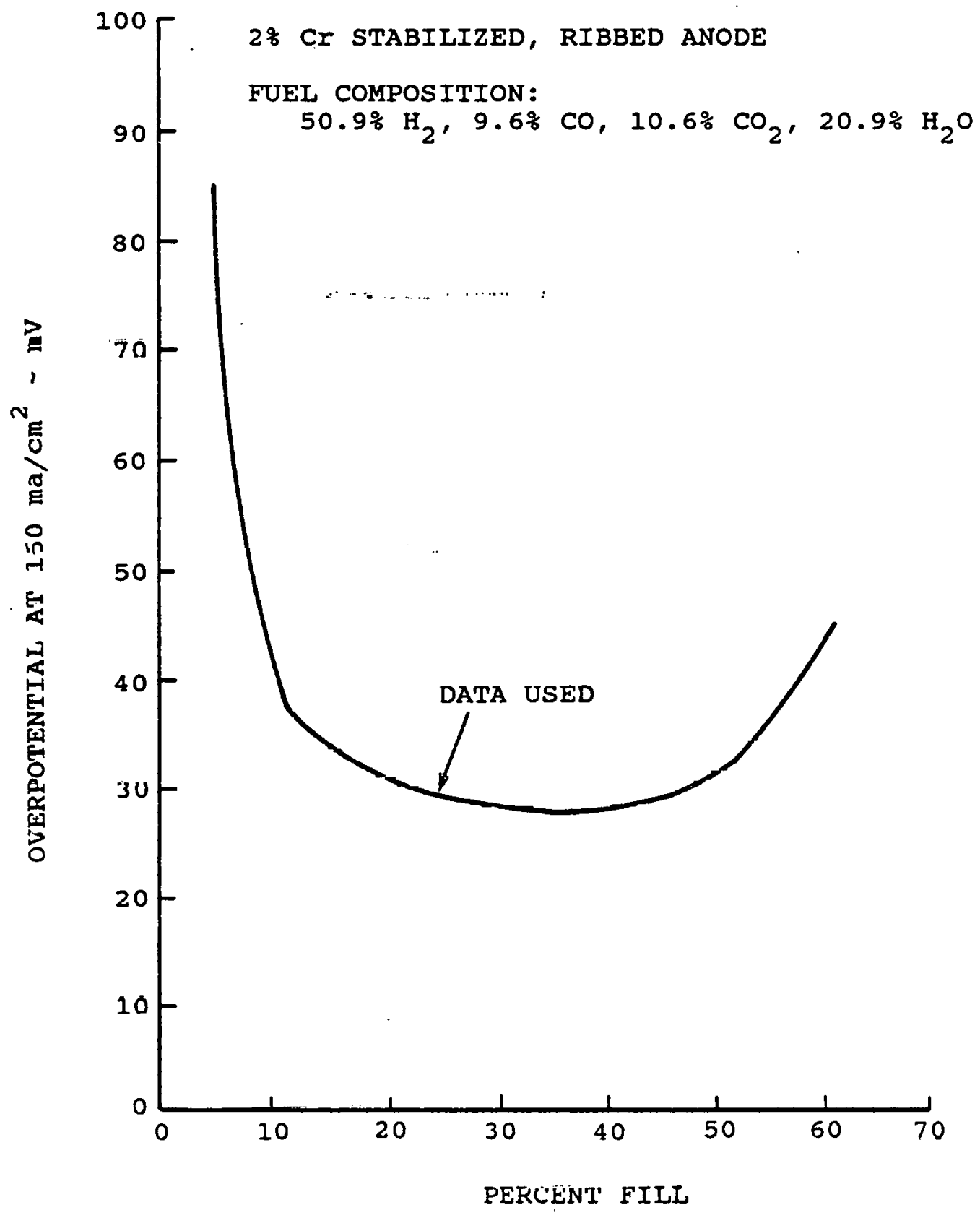

Figure 6-3. Performance Versus Electrolyte Fill for Anode $6-10$ 
'HABLE $8-1$

\section{ANODE POLARIZATION VALUES}

(Volts)

0.085

0.058

0.038

0.033

0.031

0.0295

0.0285

0.028

0.0285

0.032

0.046
\& Fill

2.5

5.0

10.0

15.0

20.0

25.0

30.0

35.0

40.0

50.0

60.0
$\mathrm{mA}\left(\mathrm{g} / \mathrm{cm}^{2}\right)$

0.002883

0.005765

0.01153

0.017295

0.02306

0.028825

0.03459

0.040355

0.04612

0.05765

0.06918 
The total mass of electrolyte in the cell decreases with time because of the accelerated evaporation caused by the halides. This rate of loss at pseudo steady state can be calculated by noting that the inlet halide flow in both the fuel and oxidant contribute to the loss. The resulting equation for electrolyte mass per unit frontal area is:

$$
\begin{aligned}
M=0.1066 & -\frac{3600(91.89)(I / A)}{96,500}\left(\frac{x H+x C O+x C+x H O}{X H+x C O}\right)\left(\frac{P C L+P F}{F U}\right) T \\
& -\frac{3600(91.89)(F / A)}{96,500}\left(\frac{X O+X O C+X N+X O H}{X 0 C}\right)\left(\frac{F+C L}{0 U}\right) T
\end{aligned}
$$

where 91.89 is the molecular weight of the electrolyte and 96500 is Faraday's constant. The relative loss rates of lithium and potassium halides are near the relative lithium and potassium contents in the electrolyte, so no change in composition of the electrolyte is assumed.

The quantity 0.1066 in Equation $(6-24)$ is the initial mass of electrolyte in the cell per unit area, calculated in the manner shown in Table 6-2.

The polarization of this anode at optimum fill at $160 \mathrm{~mA} / \mathrm{cm}^{2}$ was measured as a function of fuel composition [27] and found to vary with the concentration of hydrogen in the fuel gas according to the equation.

$$
n_{A}=\frac{2.418 \times 10^{-2}}{\left(P_{H_{2}}\right)^{1 / 2}}+8 \times 10^{-3}
$$

The square root dependence is considered to be present because of the importance of surface diffusion in the anode. This equation predicts a somewhat higher overpotential (42 mV) compared to the data in Figure 6-3 (28 mV). correcting for this difference, the overpotential of the anode in the absence of halides, accounting for the cffccts of liydrugen pressure and electrolyte content is:

$$
3_{A}=\left[\frac{2.418 \times 10^{-2}}{\left(P_{H_{2}}\right)^{1 / 2}}+8 \times 10^{-3}\right]\left[\frac{f(M A)}{0.028}\right]
$$


TABLE 6-2

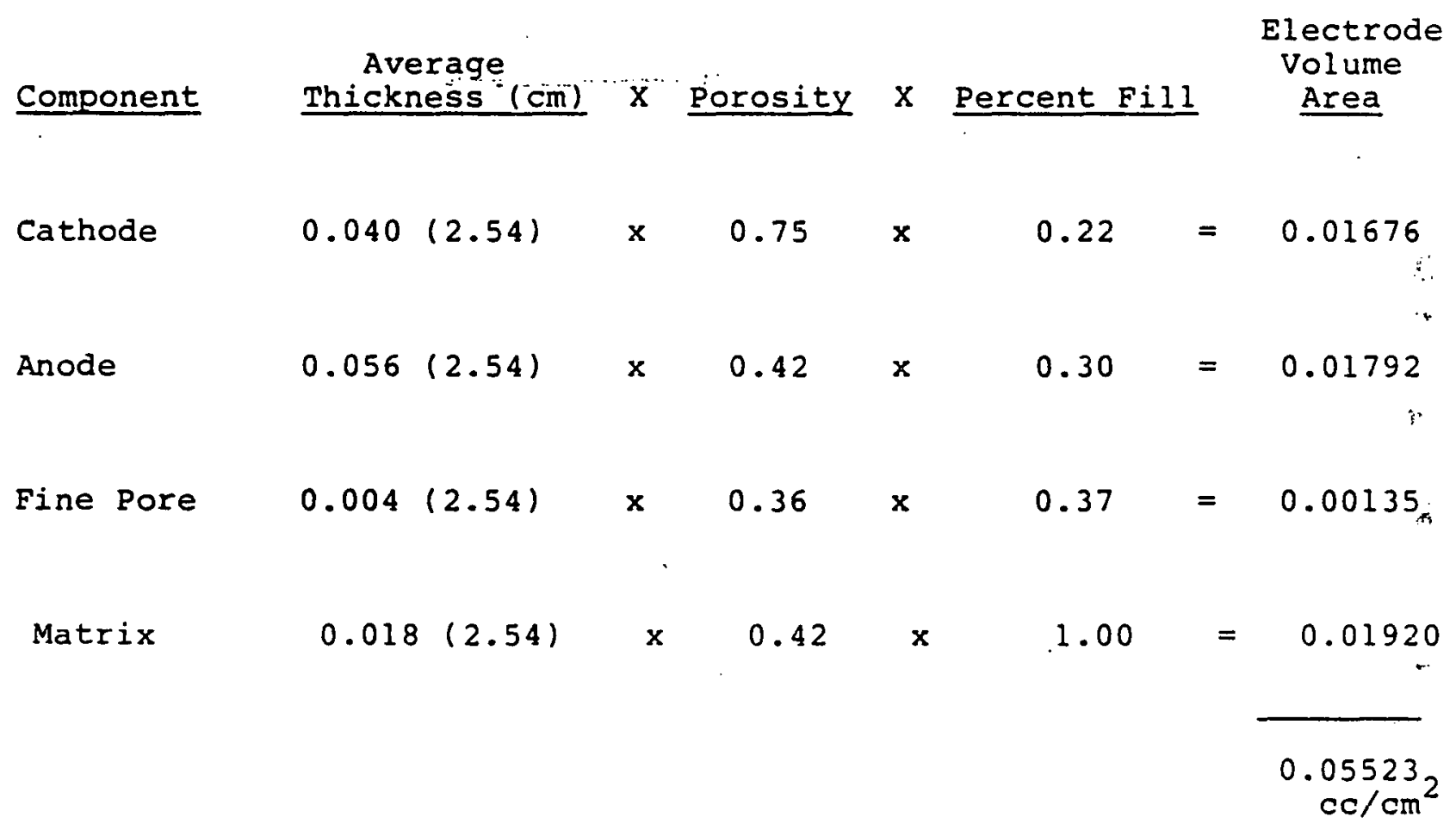

With Electrolyte Density of $1.93 \mathrm{~g} / \mathrm{cc}$, Initial

Mass of Electrolyte Is

$1.93 \times 0.05523=0.1066 \mathrm{~g} / \mathrm{cm}^{2}$ 
The halides are suspected to poison the anode reaction because of the rapid loss of performance experienced by cells in which chloride was introduced into the anode gas. Not enough chloride was introduced to convert much electrolyte to chloride in the time period in which the performance loss occurred. Enough chloride was introduced, however, to considerably cover the anode catalyst surface area. Chloride has been found to poison fuel reforming nickel catalyst which had been activated with alkali [28].

The adsorption of halide on. the. surface of the anode catalyst competes with the adsorption of hydrogen.

For hydrogen,

$$
H_{2}+2 S \rightarrow 2(S \cdot H) \quad(\text { Reaction } 1)
$$

For chloride, $\mathrm{MCl}+\mathrm{S}-\mathrm{S} \cdot \mathrm{MCl}$ (Reaction 2)

For fluoride, $M F+5=5 \cdot M F$ (Reaction 3)

where $M$ is an alkali metal and $S$ is a surface site.

The equilibrium constants for these reactions are, respectively:

$$
\begin{aligned}
& K_{1}=\frac{(S \cdot H)^{2}}{P_{H_{2}} S^{2}} \\
& K_{2}=\frac{S \cdot M C l}{P_{M C 1} S} \\
& K_{3}=\frac{S \cdot M F}{P_{M F} S}
\end{aligned}
$$


For the competitive adsorption of hydrogen and one halide, say chloride,

$$
S+S \cdot H+S \cdot M C l=1
$$

Equations $(6-30),(6-31)$, and $(6-33)$ can be solved to give

$$
S \cdot H=\frac{P_{H_{2}}{ }^{1 / 2}}{P_{H_{2}}^{1 / 2}+\frac{K_{2}}{K_{1}^{1 / 2}} P_{\text {mal }}+\frac{1}{K_{1}^{1 / 2}}}
$$

If the empirically determined dependency of anode overpotential on the square root of hydrogen pressure in Equation $(6-25)$ is considered to be due to the square root dependency of hydrogen converage seen in Equation $(6-34)$, the manner in which chloride affects the anode polarization can be estimated. If the rate of anode reaction depends on $S H$, Equation $(6-25)$ implies that. $K_{l}$ may be small. Then

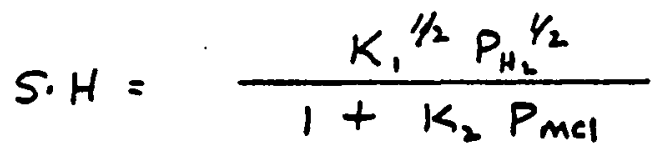

With both halides present,

$$
S \cdot H=\frac{K_{1}^{1 / 2} P_{H_{2}}^{1 / 2}}{1+K_{2} P_{M C 1}+K_{3} P_{M F}}
$$

Therefore, $\mathrm{P}_{\mathrm{H}_{2}} 1 / 2$ in Equations $(6-25)$ and $(6-26)$ are replaced by $\mathrm{P}_{\mathrm{H}_{2}}{ }^{1 / 2}$ times a multiplier of

$$
F G=\frac{1}{1+K_{2}\left(P_{T}\right)(L O)+K_{3}\left(P_{T}\right)\left(F_{O}\right)}
$$

for pseudo steady-state.

For short times, the nickel catalyst is assumed to adsorb all of the halides that enter the cell. No coupling with halide converting the electrolyte or leaving the cell is assumed. These assumptions are made because of the previous cell data with halides in the reactant and the scrubbing of 
halides from the fuel until breakthrough occurs as described under the section on concentration polarization. For these short times, the area is reduced by the factor

$$
\begin{aligned}
& F F=1-\begin{array}{l}
\text { Fraction of Area } \\
\text { Covered by Chloride - }
\end{array} \\
& F F=1-\frac{6.023 \times 10^{23}\left(\frac{\text { MOLECULES }}{\text { MOLE }}\right) \cdot T(H R) \cdot \frac{A R G A}{\text { MOLGCULE }}}{\frac{A_{\text {NIEKEL }}}{\mathrm{CM}^{2} \text { FROMML }}} \times \\
& \left\{\frac{2(3600)(J / A)}{96,500}\left[\left(\frac{P F+P C}{F U T}\right) \frac{1}{(x H+x C O)}+\left(\frac{C L+F}{0 U T}\right) \frac{1}{\times 0 C}\right] \frac{\text { moces }}{\text { He } \mathrm{Cm}^{2}}\right\}(6-39)
\end{aligned}
$$

where $6.023 \times 10^{23}$ moles is Avagadro's number. The area of nickel covered per molecule of halide was obtained from Reference [28] as $6.28 \mathrm{x}$ $10^{-6} \mathrm{~cm}^{2} / \mathrm{site.}$ The surface area of the nickel per unit frontal area is 531 , considering a $0.142 \mathrm{~cm}$ thick anode of 0.42 porosity with a surface area of $0.1 \mathrm{~m}^{2} / \mathrm{g}$ and a density of $8.9 \mathrm{~g} / \mathrm{cc}$. Equation $(6-39)$ then becomes

$$
F F=1-7.37 \times 10^{-5} T\left\{\frac{2(3600 X X I / A)}{96,500}\left[\left(\frac{P F+P C L}{F U T}\right) \frac{1}{(2 H+x<0)}+\left(\frac{C L+E}{0 U T}\right) \frac{1}{\times 0 O}\right]\right\}
$$

For short time periods, while the halide is adsorbed and approaching steadystate coverage, $F F$ should be used as the multiplier for $\mathrm{P}_{\mathrm{H}_{2}} \mathrm{I} / 2$ in Equations (6-25) and (6-26). This multiplier is used until it exceeds FG. Then FG is used.

Increases in anode polarization can lead to changes in the adsorption characteristics of species on the anode surface due to its increasing potential. Eventually the nickel will oxidize. These effects are not included.

The increase in utilization loss on the fuel side can be determined by calculating the difference in anode polarization at the inlet hydrogen pressure with halide-containing reactants to that at the average hydrogen pressure with halide-containing reactants. 
The exit hydrogen pressure is:

$$
P_{H_{2} \text { OUT }}=P T\left[\frac{(1-F U T) \times H}{(1+F U T)(\times H+\times C O)+\times \mathrm{CO}_{2}+\times H_{O}}\right]
$$

The average hydrogen pressure is:

$$
\bar{P}_{H_{2}}=\left[(P T X \times H)+P_{H_{2} \text { OUT }}\right] / 2
$$

The anode polarization at this pressure in the presence of halides is, from Equation $(6-26)$,

$$
\eta_{B}=\left[\frac{2.418 \times 10^{-2}}{\left(\bar{P}_{H_{2}}\right)^{1 / 2}(E)}+8 \times 10^{-3}\right]\left[\frac{f(\mathrm{MA})}{0.028}\right]
$$

where $\mathrm{E}$ is FF or FG depending on whether steady state has been reached with respect to poisoning of the anode reaction. The utilization loss is then $Z_{B}-\eta_{A}$, where $\eta_{A}$ is obtained from Equation $(6-26)$.

\section{Cathode Polarization}

The performance of cathodes is also affected by both conversion of the :electrolyte composition and loss of electrolyte. As described under the section on concentration polarization, the cathode electrolyte is considered to be essentially free of any halides during cell operation because of the production of carbonate ions there. The overpotential of the cathode as a function of electrolyte is shown in Figure 6-4. The composite graph shown is fit by the equation

$$
n_{c}=26.82(m c)^{2}-2.76(m c)+0.120
$$




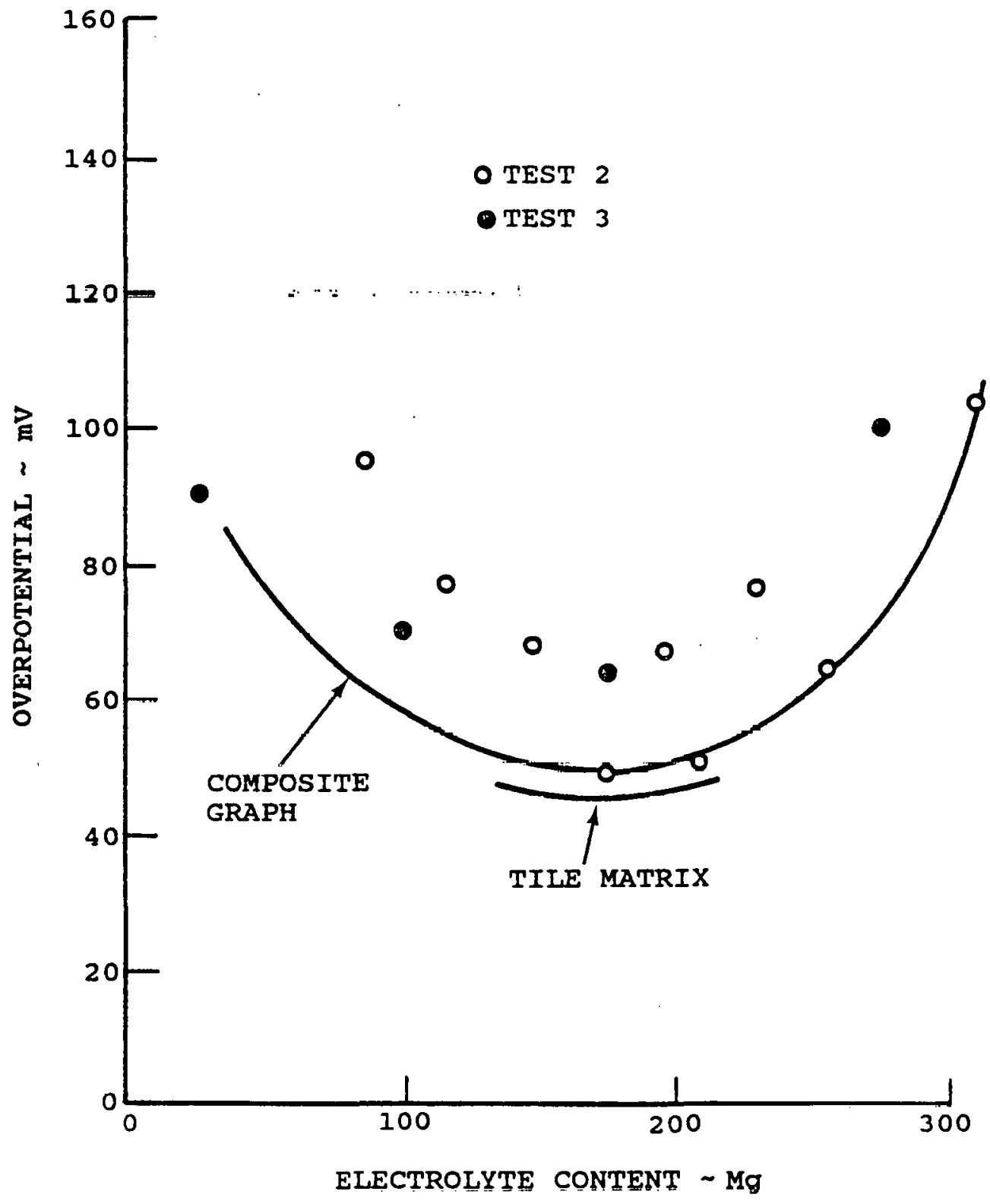

Figure 6-4. Summary of Cathode Performance on Halide-Free Electrolyte

$$
6=18
$$


at $160 \mathrm{~mA} / \mathrm{cm}^{2}$ where $\mathrm{MC}$ is the mass of electrolyte in the cathode per unit frontal area. This mass is calcualted from the total mass of electrolyte in the cell using Equation (6-24) and the electrolyte sharing analysis.

\section{Matrix Polarization}

The matrix is also assumed to operate relatively free of halide to the point that the electrolyte conductivity there will not be significantly changed. The matrix resistance will increase due to loss of electrolyte, however. The relationship between matrix polarization and electrolyte content is:

$$
z_{m}=0.020\left[\frac{(0.01920 \times(1.93)}{\mathrm{mm}}\right]^{1.5}
$$

where MM is the mass of electrolyte in the matrix per unit frontal area. This equation holds at $100 \mathrm{~mA} / \mathrm{cm}^{2}$ and is based on an initial volume of $0.01920 \mathrm{cc}$ of electrolyte in a 100 percent filled matrix, a density of $1.93 \mathrm{~g} / \mathrm{cc}$, and an initial polarization of $20 \mathrm{mV}$ due to the matrix. At $150 \mathrm{~mA} / \mathrm{cm}^{2}$, this expression becomes:

$$
\eta_{m}=\frac{2.28 \times 10^{-4}}{(\mathrm{Mm})^{1.5}}
$$

The exponent 1.5 accounts for both the change in area for ion flow in the matrix and the increase in tortuosity of the matrix based on the Bruggeman Equation [25].

\section{Computer Model Description}

Using the equations presented in the section on model development, a computer program, MCHALIDE, was developed which calculates the performance decay of the present molten carbonate fuel cell due to the presence of hydrogen 
chloride and hydrogen fluoride in the fuel or oxidant. The performance decay is caused by the loss of electrolyte, which affects the performance of the anode, cathode, and matrix, the conversion of the electrolyte to a halidel carbonate mixture, and the possible poisoning of the anode catalyst by halide

The design of the cell and its initial electrolyte content are built into the program. The loss of electrolyte is assumed to be caused only by the presence of a halide in the reactant, even though electrolyte loss occurs in actual cells in the absence of halides.

The operating pressure, current density, fuel inlet composition, and oxidant utilization, and the chloride and fluoride content in the inlet fuel and oxidant are all input variables. The fuel utilization is based on the consumption of both $\mathrm{H}_{2}$ and $\mathrm{CO}$, while the oxidant utilization is based on the consumption of $\mathrm{CO}_{2}$. These input variables are printed out with the program results.

The various sources of performance loss are calculated using the model and tabulated as a function of time from 0 to 40,000 hours. These polarization components are:

- 'lhe anode polarization including the fuel utilization loss.

- The cathode polarization including the oxidant utilization loss.

- The matrix resistance loss.

- The concentration polarization and liquid-junction potential loss caused by chloride in the electrolyte.

- The concentration polarization and liquid-junction potential loss caused by flouride in the electrolyte.

- The total of all these losses.

- The electrolyte content in the cell active area per unit active area.

- The cell performance loss due to halides caused by the change in the total of these losses. 
The $\mathrm{HCl}$ and $\mathrm{HF}$ present in the fuel and oxidant inlet gases are considered to be completely scrubbed from the gases within the stack and converted into lithium and potassium chlorides and fluorides. The halide content is assumed to increase in the cell with time until a pseudo steady-state is reached, where the halide influx as $\mathrm{HCl}$ and HF match the outflow as $\mathrm{L} i$ and $K$ salts. These salts are assumed to be concentrated in the anode during cell operation and saturate the fuel exhaust gas. No halides are assumed to leave in the oxidant effluent. It is assumed that the fuel exhaust gas is not used to provide $\mathrm{CO}_{2}$ to the oxidant inlet, thereby permanently removing the halide from the cell in the fuel effluent. This method of operation duplicates that used in subscale cell tests, but not that in present system configurations.

The condition at which the influx and outflux are equal is only a pseudo steady-state because the electrolyte content in the cell decreases with time after this state is reached.

\section{Comparison of Model Results with Cell Data}

Experimental data on the effects of hydrogen chloride present in the fuel gas of a molten carbonate fuel cell were previously obtained by IFC under Contract DE-AC-01-79ET15440 with DOE. The experimental conditions under which those tests were performed are listed in Table 6-3. Two different hydrogen chloride contents were introduced into the fuel gas, first $60 \mathrm{ppm}$ and then $10 \mathrm{ppm}$. Prior to the introduction of the $10 \mathrm{ppm} \mathrm{HCl}$, the performance of the cell was allowed to recover.

The measured increases in polarization with time after the introduction of the $\mathrm{HCl}$ for both of these cases are shown in Figure 6-5. The data for the $60 \mathrm{ppm}$ case show that over a $50 \mathrm{mV}$ increase in cell polarization occurs in less than two hours. Such a rapid performance loss might be 
TABLE $6-3$

\section{EXPERIMENTAL CONDITIONS FOR}

\section{PREVIOUS CHLORIDE TESTS}

( $\operatorname{Cel1}$ No. 319)

Fuel Composition:

$$
\begin{aligned}
& 51.0 \text { mole } 8 \mathrm{H}_{2}, 9.6 \text { mole } 8 \mathrm{CO}, 10.6 \mathrm{~mole} \& \mathrm{CO}_{2} \\
& 28.8 \text { mole } 8 \mathrm{H}_{2} \mathrm{O}
\end{aligned}
$$

oxidant Composition:

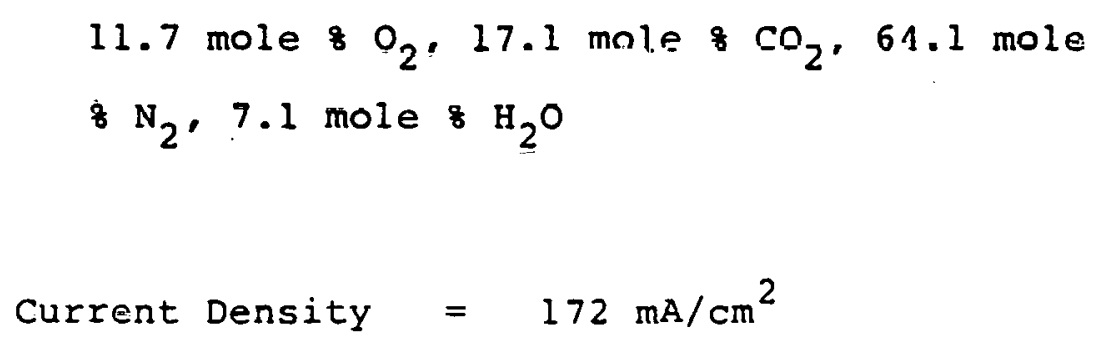




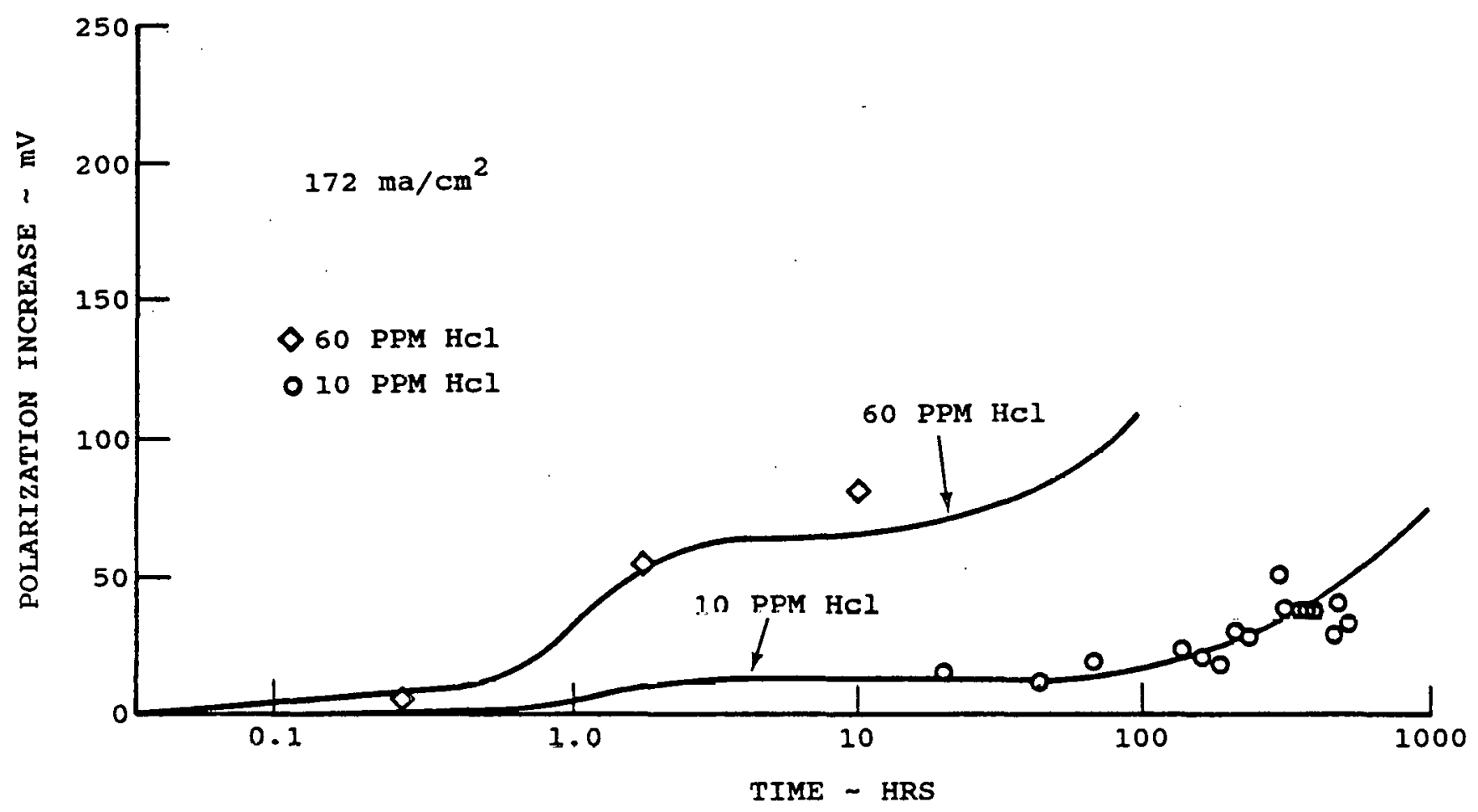

Figure 6-5. Comparison of Preliminary Model with Existing Cell Data for Early Time Periods with $\mathrm{HCl}$ in Fuel 
expected to be caused by a poisoning of the anode by chloride. However, experimental anode half-cell data obtained in this contract indicate that anodes are not poisoned by the presence of chloride.

An alternative explanation for the rapid polarization increase is a rapid conversion of a fraction of the electrolyte in the anode to a mixture of carbonate and chloride. As defined in the section on Model Development, a fraction $z$ of the total anode electrolyte is considered to be present in thin films in the anode and introduce:concentration polarization and liquid junction potential before the electrolyte in total anode reached pseudo steady state. A value of $z$ equal to 0.01 was found to lead to very good agreement with the experimental data in early time periods for both the $60 \mathrm{ppm}$ and $10 \mathrm{ppm}$ cases, as can be seen in Figure 6-5. The steady state concentration polarizations for these two cases are $63 \mathrm{mV}$ and $12 \mathrm{mV}$ respectively. The levels of these polarizations are not affected by the selection of $\mathrm{z}$, but only by the time at which they occur.

For time periods above about 100 hours for the $10 \mathrm{ppm}$ case, the polarization increase due to halides increases above the $12 \mathrm{mV}$ associated with the concentration polarization and liquid junction potential. The model indicates that this additional loss is due to a loss of electrolyte. This cell was filled with $11.6 \mathrm{~g}$ of electrolyte when the amnunt in the matrix and Ine pore in the wet seals is subtracted from the total initial electrolyte mass. If the cell is assumed to have lost 3 to $6 \mathrm{~g}$ due to creepage through the cell seals in the 876 hours before the $10 \mathrm{ppm}$ HCl were introduced, as indicated in [27], about 6 to $9 \mathrm{~g}$ of electrolyte were in the cell when the $10 \mathrm{ppm} \mathrm{HCl}$ test began. The $60 \mathrm{ppm}$ test is estimated to have resulted in only a $0.08 \mathrm{~g}$ loss. The line increasing above the $12 \mathrm{mV}$ increase in polarization from concentration polarization for the 10 ppm case shows the calculated additional increase due to the loss of electrolyte, assuming $7 \mathrm{~g}$ of electrolyte were present at the time the $10 \mathrm{ppm} H C l$ were intro duced. The increased polarization is readily explained by this mechanism. 
Teardown analysis of this cell indicated that it was low in electrolyte.

The total decay in performance due to chloride in the fuel can therefore be explained by the consideration of two loss mechanisms: concentration polarization, liquid junction potential due to electrolyte composition differences between the electrodes and loss of electrolyte from the cell. This result is surprising since in this study chloride in the electrolyte was measured in half-cell tests to have a large effect in increasing cathode polarization. An explanation:for this apparent discrepancy is that the cathode in the half-cell tests was held for several days in chloridecontaining electrolyte at open circuit prior to being placed on current load. Under such circumstances, the cathode could have reacted with the chloride. In the cell test, the cathode was almost continuously on load, generating carbonate, thereby cleansing itself of chloride and avoiding the reaction with the chloride.

An attempt was made to compare the results predicted by this model with experimental data obtained by General Electric Company on the effects 0 of $\mathrm{HCl}$ in the fuel and oxidant [1]. However, comparisons could not be made because of the different cell configuration, the manner in which the tests were performed with short periods of open-circuit operation during the test, and General Electric's use of simulated air-blown gasifier fuel instead of oxygen-blown gasifier fuel.

The data indicates that the effect of hydrogen chloride is much greater when it is introduced in the oxidant stream than when it is introduced in the fuel stream at the same concentration levels. This much more severe effect is predicted by the model to be caused by a greatly increased concentration polarization and liquid junction potential due to the higher rate of hydrogen chloride flow into the cell caused by the higher oxidant volume flow rate. Possibly, an increase in cathode polarization also occurs due to the presence of chloride in the oxidant as indicated by the half-cell data of the present study. Deterioration of the structural integrity of the cathode was apparent on teardown. 
TABLE OF NOMENCLATURE

Computer Text

Symbol

Symbol
Definition

Units

amps

Anion fraction carbonate in anode due to chloride conversion in short times

Anion fraction carbonate in anode due to fluoride conversion in short times

BC

$\mathrm{C}_{\mathrm{ACL}}$

Chloride anion fraction in anode

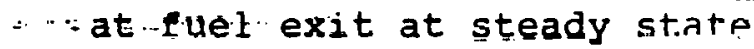

$\mathrm{BD}$

$\mathrm{C}_{\mathrm{AF}}$

CC

3 conc

Chloride

CD

3 conc

CE

\}one

CF

Zone
Fluoride

Density

$\rho$

FF

FF

FG

FG

FO

FO

IA

$I / A$

KHR

$\mathrm{K}_{3}$

$-$

KTW

LO
$\mathrm{K}_{1}$

$\mathrm{K}_{2}$

LO
Fluoride anion fraction in anode at fuel exit at steady state

Concentration polarization due to chloride in short times

Concentration polarization at steady state due to chloride

Concentration polarization at steady state due to fluoride

Cuncencration polarization due to eluoride in short times

Electrolyte density

Multiplier on $\mathrm{H}$ adsorption area in short times defined by Equation (39)

Multiplier on $\mathrm{H}$ adsorption area in steady state defined by Equation (37)

Mole fraction of fluoride in

fuel effluent at steady state

Current density

Equilibrium constant for Reaction 3

amps $/ \mathrm{cm}^{2}$

$\mathrm{ATM}^{-1}$

Equilibrium constant for Reaction 1

$\mathrm{ATM}^{-1}$

Equilibrium constant for Reaction 2

$\mathrm{ATM}^{-1}$
Mole fraction of chloride in fuel

effluent at steady state 
M

MA

MC

MM

NA

NB

NC

NU

PO

PR

PS

PT

T

Total

UCO2C OUT

UH2COA FUT

$x$

XCLA

XCOAIN

XCO2AIN $X C$

$X \mathrm{CO} 2 \mathrm{CIN} \quad \mathrm{XOC}$

XH2AIN $\quad$ XH

XH2OCIN $\mathrm{XOH}$
Mass of electrolyte in cell/area

Mass of electrolyte in anode/area

Mass of electrolyte in cathode/area

Mass of electrolyte in matrix/area

Anode polarization at $160 \mathrm{ma} / \mathrm{cm}^{2}$

Anode polarization at utilization at $160 \mathrm{ma} / \mathrm{cm}^{2}$

Cathode polarization at $160 \mathrm{ma} / \mathrm{cm}^{2}$

Fuel side utilization loss at $160 \mathrm{ma} / \mathrm{cm}^{2}$ Volts

Hydrogen pressure at fuel exit

ATM

Average hydrogen pressure

ATM

Total cell polarization (less oxidant and fuel normal utilization losses)

Total pressure

ATM

Time

Hours

Total cell polarization

Volts

oxidant $\left(\mathrm{CO}_{2}\right)$ utilization

Fuel ( $\mathrm{H}_{2}$ and $\left.\mathrm{CO}\right)$ utilization

Fraction of electrolyte in anode

for transient halide storage

Mole fraction of chlorine in fuel

Mole fraction of carbon monoxide in fuel

Mole fraction of carbon dioxide in fuel

Mole fraction of carbon dioxide in oxidant

Mole fraction of hydrogen in fuel

Mole fraction of water in oxidant 


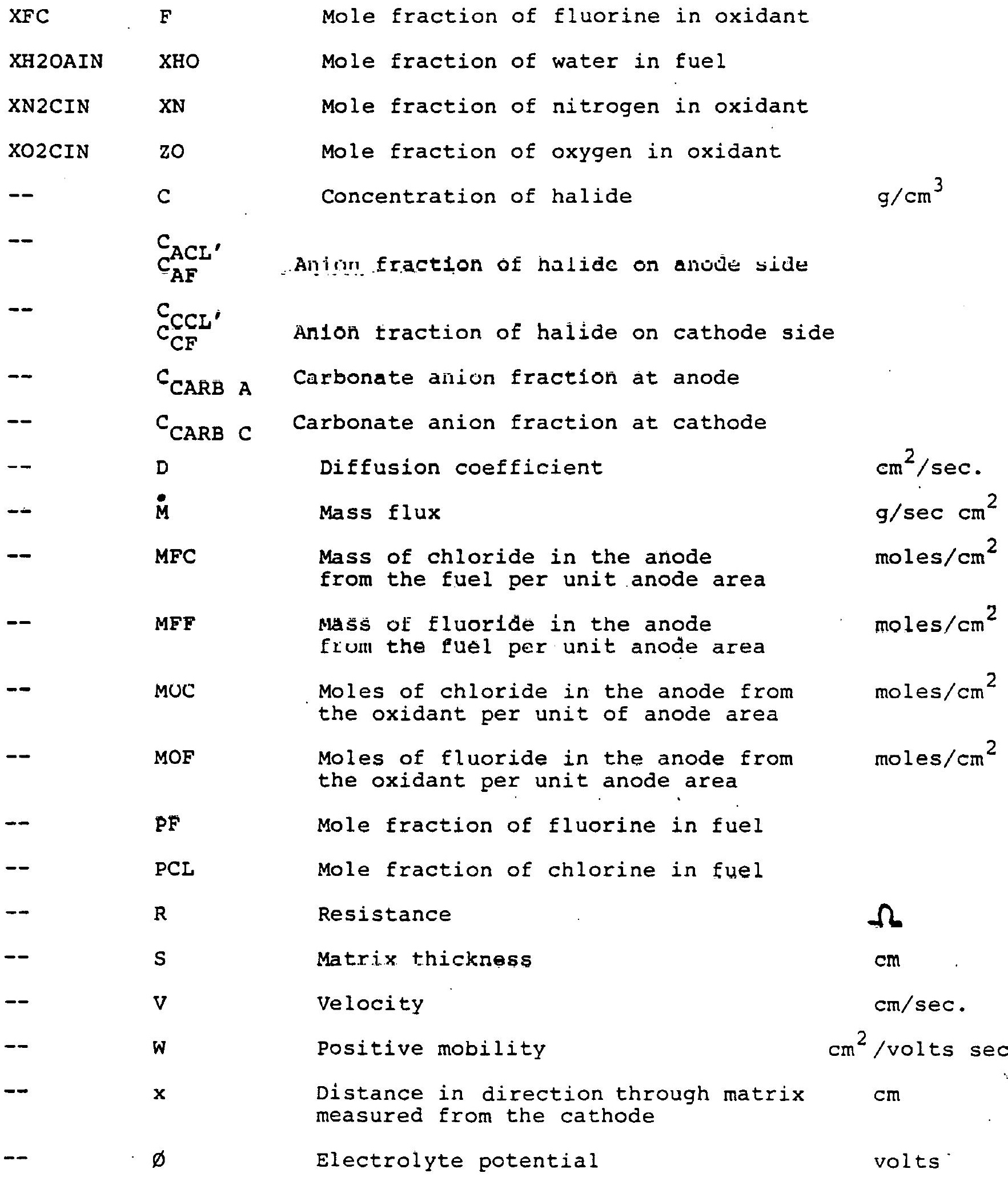


CONCLUSIONS AND RECOMMENDATIONS

\section{ESTIMATED CELI TOLERANCE TO HALIDES}

The overall objective of this contract was "to develop a model and to determine the probable limits of halides in fuel and oxidant streams to achieve a desired coal-gas-fueled molten carbonate fuel cell life between 25,000 to 40,000 hours". The description of the model and its comparison with existing experimental data are discussed in the previous section. This section describes the application of the model to the prediction of halide tolerance for a typical set of molten carbonate fuel cell operating conditions.

The tolerance of the cell stack to halides was found to depend on the cell design and its electrolyte inventory, the operating conditions of the stack and the system which incorporates the stack. For a stack operating at the conditions shown in Table 7-1 at 10 atm pressure, where none of the halide leaving the stack in the fuel enters the stack in the oxidant gas, the tolexance level to both $\mathrm{HCl}$ and $\mathrm{HF}$ is shown in this section to be about 0.1 ppm based on a performance loss of $20 \mathrm{mV}$ in 40,000 hours.

The reactant compositions presented in Table 7-1 are the same as those used in the experiments performed under this contract and are representative of operation with an oxygen-blown Texaco gasifier and an oxidant with a reduced carbon dioxide pressure to extend the life of the nickel-oxide cathode. Two pressure levels were selected to demonstrate the effect of this variable.

The model was used to estimate the decline in performance with time due to the presence of halides for four cases: hydrogen chloride in the fuel and oxidant and hydrogen fluoride in the fuel and oxidant. The performance decay after 40,000 hours of operation is shown as a function of halide content in Figure 7-1. These decay levels are those due only to the presence of halide and do not include any decay due to other sources. Other decay modes include electrolyte loss, nickel-oxide cathode dissolution, current collector corrosion, cathode compaction, and anode creepage all in the absence of halides [29]. 


\section{TABLE 7-1}

$\begin{array}{ll}\text { Operating Pressure } & =10 \mathrm{~atm}, 1 \mathrm{~atm} \\ \text { Operating Temperature } & =650^{\circ} \mathrm{C} . \\ \text { Current Density } & =172 \mathrm{~mA} / \mathrm{cm}^{2} \text { (160 ASF) }\end{array}$

Fuel Composition:

$$
\begin{aligned}
& 29.4 \mathrm{~m} \% \mathrm{H}_{2} \\
& 5.5 \mathrm{mg} \mathrm{CO} \\
& 17.5 \mathrm{~ms}^{8} \mathrm{CO}_{2} \\
& 47.6 \mathrm{~m}^{\circ} \mathrm{H}_{2} \mathrm{O}
\end{aligned}
$$

Fuel Ujtilization $\left(\mathrm{H}_{2}+\mathrm{CO}\right)=85 \%$

Oxidant Composition:

$$
\begin{array}{lll}
9.6 & \mathrm{~m} & \mathrm{O}_{2} \\
7.2 & \mathrm{~m} & \mathrm{CO}_{2} \\
64.6 & \mathrm{~m} \% \mathrm{~N}_{2} \\
18.7 & \mathrm{~m} \% & \mathrm{H}_{2} \mathrm{O}
\end{array}
$$

Oxidant Utilization $\left(\mathrm{CO}_{2}\right)=37 \%$

Operating Time $=40,000$ hours 


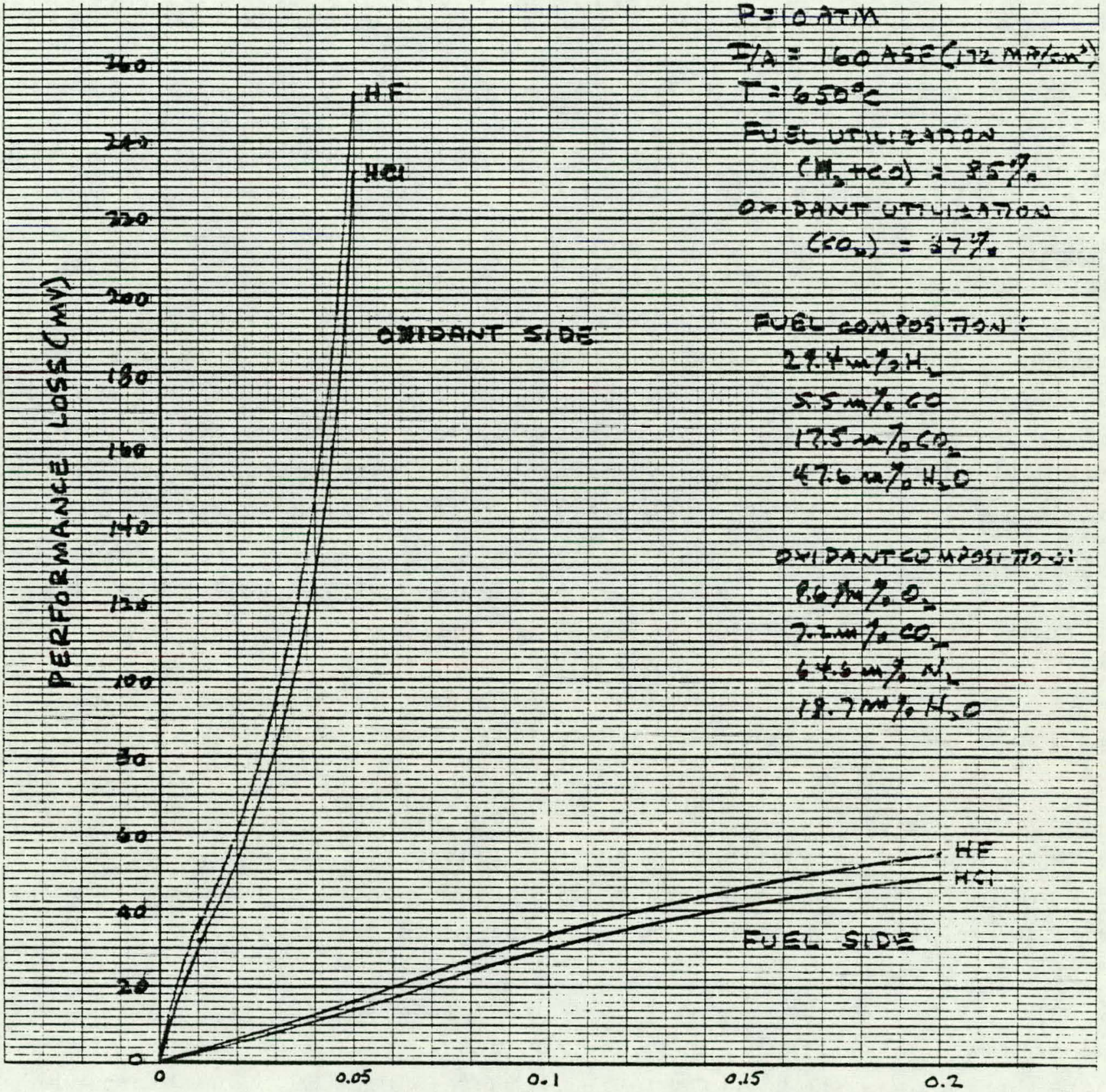

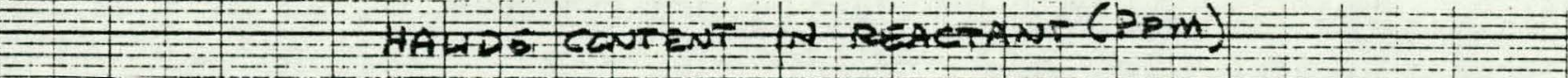
FIGURE 7-1. Predicted Performance Decay in 40,000 Hours Due to Halides 
The performance loss due to halides shown in Figure 7-1 indicates that the tolerance to halides is very small, tenths of a ppm in the fuel gas and hundreths in the oxidant for a $20 \mathrm{mV}$ performance loss. The reason for the small tolerance can be seen in Table 7-2 which shows the breakdown of the performance loss into its components for the particular case of $0.1 \mathrm{ppm}$ $\mathrm{HCl}$ in the fuel gas and $10 \mathrm{~atm}$ operating pressure. This tahle shows the polarization levels of each of the contributors to the total loss as a function of operating time. Those components are the anode polarization, cathode polarization, matrix resistance, and the performance loss due to differences in halide ion concentrations between the electrodes. The total cell polarization and cell electrolyte content are shown in the last two columns. The total cell polarization here contains only those elements of polarization that are affected by halides and, therefore, should not be used to estimate cell performance by subtraction of the total cell polarization from the open circuit voltage.

Almost all of the performance loss can be seen to he caused by elcctrolyte luss. Most of the performance loss is associated with electrolyte loss from the anode and occurs after 10,000 hours of operation. Only 12 percent of the electrolyte is lost in 40,000 hours. Because electrolyte loss is the major mode of decay, increasing the electrolyte inventory of the cell package, improving its tolerance to electrolyte loss, and adding electrolyte during power plant life would increase tolerance to halides.

The validity of electrolyte loss as a decay mode is increased because this mode of decay is similar to that seen by the in-cell test using $10 \mathrm{ppm} \mathrm{HCl}$ in the fuel gas as shown by Table 7-3. There, about $12 \mathrm{mV}$ was lost due to the chloride concentration difference and the rest was due to electrolyte loss, primarily from the anode. Table 7-4 shows that the performance of the in-cell test using $60 \mathrm{ppm} \mathrm{HCl}$ in the fuel gas decayed in 10 hours primarily due to the chloride concentration difference and not electrolyte 
TABLE 7-2

COMPONENT POLARIZATIONS

$$
\begin{gathered}
P=10 \mathrm{ATM} \\
I / \mathrm{A}=160 \mathrm{ASF}\left(172 \mathrm{~mA} / \mathrm{cm}^{2}\right) \\
O^{\circ} \mathrm{I}=\mathrm{PPM} \mathrm{HCI} \text { IN FUEL ONLY }
\end{gathered}
$$

\begin{tabular}{|c|c|c|c|c|c|c|c|}
\hline $\begin{array}{l}\text { Time } \\
\text { (hours) }\end{array}$ & $\begin{array}{l}\text { Anade } \\
\text { (volts) }\end{array}$ & $\begin{array}{l}\text { Cathode } \\
\text { (valts) }\end{array}$ & $\begin{array}{l}\text { Matrix } \\
\text { (volts) }\end{array}$ & $\begin{array}{l}\text { Cl cone. } \\
\text { (volts) }\end{array}$ & $\begin{array}{l}\text { F cone. } \\
\text { (volts) }\end{array}$ & $\begin{array}{l}\text { Total } \\
\text { (volts) }\end{array}$ & $\begin{array}{l}\text { Elyte } \\
(g m / \operatorname{cm} 2)\end{array}$ \\
\hline 0.0 & 0.1045 & 0.0834 & 0.0349 & 0.0000 & 0.0000 & & 0.0680 \\
\hline 0.1 & 0.1045 & 334 & 0.0349 & 0.0000 & 0.0000 & 0.2229 & 0.0680 \\
\hline 0.4 & 0.1045 & 0.0834 & 0.0349 & 0.0000 & 0.0000 & 0.2229 & 0.0680 \\
\hline 1.0 & 0.1045 & 0.0834 & 0.0349 & 0.0001 & 0.0000 & 0.2229 & 0.0680 \\
\hline 4.0 & 0.1045 & 0.0834 & 0.0349 & 0.0001 & 0.0000 & 0.2230 & 0.0680 \\
\hline 10.0 & 0.1045 & 0.0834 & 0.0349 & 0.0001 & 0.0000 & 0.2230 & 0.0680 \\
\hline 40.0 & 0.1045 & 0.0834 & 0.0349 & 0.0001 & 0.0000 & 0.2230 & 0.0680 \\
\hline 100.0 & 0.1046 & 0.0 & 0.0349 & 0.0001 & 0.0000 & 0.2231 & $0 . c$ \\
\hline 400.0 & 0.1046 & 0.0835 & 0.0349 & 0.0001 & 0.0000 & 0.2232 & 0.0679 \\
\hline 1000.0 & 0.1048 & 0.0836 & 0.0349 & 0.0001 & 0.0000 & 0.2235 & 0.0678 \\
\hline 4000.0 & 0.1056 & 0.0841 & 0.0350 & 0.0001 & 0.0000 & 0.2248 & 0.0672 \\
\hline 10000.0 & 0.1077 & 0.0851 & 0.0352 & 0.0001 & 0.0000 & 0.2281 & 0.0660 \\
\hline 40000.0 & 0.1267 & 0.0893 & 0.0374 & 0.0001 & 0.0000 & 0.2535 & 0.0600 \\
\hline
\end{tabular}




\title{
TABLE $7-3$
}

\author{
COMPONENT POLARIZATIONS \\ FOR \\ 10 PPM IN-CELL TEST
}

\begin{abstract}
Input Jata
Current density 172 (inA/Cinz)

Halides in fuel inlet

ppm Cla 10.0 ppm F=0.0

Halides in oxidant inlet

Ppm Cl $=0.0$ ppm F $=0.0$
\end{abstract}

Celi temperature 1200 -(degF) "Cell pressure 1 (atm)

Fuel utilization $81(\%)$ O\%idant utilization Jo $(\%)$

Mole fractions of fuel gas at anode inlet

$H 2=0.510 \quad C O=0.096 \quad C O 2=0.106 \quad H 2 O=0.288$

Mole fractions of fuel gas at anode exit

$H 2=0.053 \quad C O=0.025 \quad C O 2=0.440 \quad H 2 D=0.483$

Mole fractions of oxidant gas at cathode inlet

$02=0.117 \quad C 02=0.171 \quad \mathrm{~N} 2=0.641 \quad \mathrm{H} 20=0.071$

Mole fractions of oxidant gas at cathode exit $02=0.099 \quad \mathrm{CO} 2=0.130 \quad \mathrm{~N} 2=0.694 \quad \mathrm{H} 20=0.077$

\begin{tabular}{|c|c|c|c|c|c|c|}
\hline $\begin{array}{l}\text { Time } \\
\text { (hours) }\end{array}$ & $\begin{array}{l}\text { Ariode } \\
\text { (volts) }\end{array}$ & $\begin{array}{l}\text { Cathode } \\
\text { (valts) }\end{array}$ & $\begin{array}{l}\text { Matrix } \\
\text { (volts) }\end{array}$ & $\begin{array}{l}\text { Cl conc. } \\
\text { (volts) }\end{array}$ & $\begin{array}{l}\text { F conc. } \\
\text { (volts) }\end{array}$ & $\begin{array}{l}\text { Total } \\
\text { (volts) }\end{array}$ \\
\hline 0.0 & 0.1877 & 0.0824 & & 0.0000 & 0000 & \\
\hline 0.1 & & & 0.0 .349 & 0.0004 & 100 & \\
\hline 0.4 & & 1824 & 0.0547 & 0.0017 & 500 & 5067 \\
\hline 1.0 & & 324 & $\$ 49$ & 4.3 & 00 & 093 \\
\hline 4.0 & & 825 & 0.0349 & 117 & 100 & 68 \\
\hline 10.0 & & 0.0825 & 0.0349 & 0.0117 & 000 & 171 \\
\hline 40.0 & 889 & 0.0828 & 0.0550 & 0.0117 & 000 & 183 \\
\hline 100.0 & & 0.0834 & 0.0 .551 & 0.0117 & 000 & 207 \\
\hline & & & & 0.0117 & 000 & \\
\hline & & & & 0.0117 & 000 & \\
\hline 4000.0 & 0.2572 & 0.1165 & 0.2352 & 0.0117 & 0.0000 & 0.6225 \\
\hline
\end{tabular}

NOTE: No electrolyte remaining in cell 


\title{
TABLE 7-4
}

\author{
COMPONENT POLARIZATIONS \\ FOR \\ 60 PPM IN-CELL TEST
}

\begin{abstract}
Cell temperature 1200 (degf) C...Cell pressure 1 (atin) Current density 172 (mA/EmZ)

Fuel utilization $81(\%)$ oxidant utilization $\$ 0(\%)$

Initial electrolyte mass 7.00 grams

Mole fractions of fuel gas at anode inlet $H 2=0.510 \quad C 0=0.096 \quad C 02=0.106 \quad H 20=0.28 B$ Mole fractions of fuel gas at anode exit $H 2=0.05 .3 \quad C 0=0.025 \quad C 02=0.440 \quad H 20=0.48 .3$

Mole fractions of oxidant gas at cathode inlet $\square 2=0.117 \quad C 02=0.171 \quad N 2=0.641 \quad H 20=0.071$

Mole fractions of oxidant gas at cathode exit $02=0.099 \quad C 02=0.130 \quad N 2=0.694 \quad H 20=0.077$

Halides in fuel inlet ppm $\mathrm{Cl}_{1}=60.0$ ppm $F=0.0$ Halides in oxidant inlet ppm $\mathrm{Cl}=0.0$ ppm $F=0.0$
\end{abstract}

\begin{tabular}{|c|c|c|c|c|c|c|c|}
\hline $\begin{array}{l}\text { Time } \\
\text { (hours) }\end{array}$ & $\begin{array}{l}\text { Anode } \\
\text { (volts) }\end{array}$ & $\begin{array}{l}\text { Cathode } \\
\text { (valts) }\end{array}$ & $\begin{array}{l}\text { Matrix } \\
\text { (volts) }\end{array}$ & $\begin{array}{l}\text { Cl conc. } \\
\text { (volts) }\end{array}$ & $\begin{array}{l}\text { F conc. } \\
\text { (volts) }\end{array}$ & $\begin{array}{l}\text { Total } \\
\text { (volts) }\end{array}$ & $\begin{array}{l}\text { Elyte } \\
\text { S gn/em }\end{array}$ \\
\hline 0.0 & 0.1877 & 0.0824 & 0.0 .549 & 0.0000 & 0.0000 & 0.3050 & 0.0680 \\
\hline 0.1 & 0.1877 & 0.0824 & 0.0349 & 0.0026 & 0.1 & 3076 & 0.0680 \\
\hline 0.4 & 0.1877 & 0.0824 & 0.0 .347 & 0.0110 & 0.0000 & 0.3160 & 0.0677 \\
\hline 1.0 & 0.1878 & 0.0825 & 0.0349 & 0.0 .24 & 0.0000 & 0.376 & 0.0679 \\
\hline 4.0 & 0.1884 & 0.0826 & $0.0 . \$ 49$ & 0.0632 & 0.0000 & 0.3692 & 0.0677 \\
\hline 10.0 & 0.1895 & 0.0850 & 0.0 .550 & 0.05 .2 & 0.0000 & 0.3707 & 0.0672 \\
\hline 40.0 & 0.2010 & 0.10846 & 0.0554 & 0.06 .2 & 0.0000 & 0.3842 & $0.065_{1}$ \\
\hline 200.0 & 1.2262 & 0.0878 & 0.0370 & 0.06 .22 & 0.0000 & 0.4142 & 0.0608 \\
\hline 400.0 & 0.2462 & 0.0997 & 0.0812 & 0.06 .2 & 0.0000 & 0.4902 & 0.0391 \\
\hline
\end{tabular}

NOTE: No electrolytg renainimi in Eell 
loss.

The reason for the small performance loss due to a small chloride concentration difference at low HCl levels in the fuel is caused by the fact that only a small chloride concentration is needed on the anode side of a cell to result in the halide evaporation rate from the anode balancing the influx in the fuel gas. This analysis calculates the flux of a opecie leaving a cell from the vapor pressure of that specie and the assumption that the specie saturates the reactant gas. This aesumption may not le valid.

Electrolyte loss from molten carbonate fuel cells is a major decay mode in the absence of halides. This loss is due primarily to creepage of the electrolyte from the cell package through the edge seals [29]. The mechanism for this creepage has been described [30]. In experiments in which the exhaust gases of a cell were scrubbed to trap the components of the evaporating electrolyte, less electrolyte was found than was anticipated based on measured vapor pressures [29]. This electrolyte loss was minor cumparea to that due to creepage. The evaporting components are thought

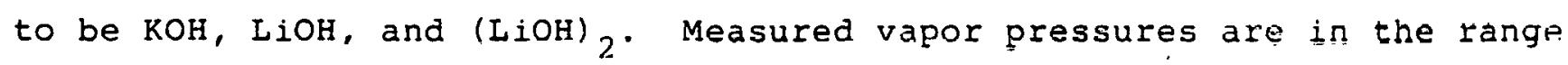
of ppm's $[31]$.

This disparity between the amount found in the reactant effluents and the anticipated values based on measured vapor pressures, makes the assumptions of the saturation of the exhaust gas with halides and complete reaction of incoming halides with the electrolyte questionable, particularly at the very low predicted tolerance levels. The 12 percent electrolyte loss in 40,000 hours, due to $0.1 \mathrm{ppm} \mathrm{HCl}$ in the fuel gas is insignificont onmarul to the 27 percent lost from the central cells in a 20 cell stack in 650 hours [30]. This electrolyte loss rate from stacks has been greatly reduced by stack design changes [32]. 
The actual electrolyte loss caused by halides is also dependent upon the molten carbonate fuel cell power plant system design. Hydrogen chloride present in gasified coal can be removed to a large extent using hot-gas cleanup. The residual $\mathrm{HCl}$ may partially react to form alkali metal chlorides in the cell stack and partially pass through the stack unreacted. The fuel exhaust gas is burned to provide carbon dioxide to the oxidant gas. Therefore, chlorides will enter the stack with the oxidant. Since some systems under consideration involve diverting some of the fuel gas for other uses such as recirculation or to provide for $\mathrm{H}_{2} \mathrm{~S}$ removal, all of the chloride leaving the stack in the fuel exhaust may not enter the stack with the oxidant. The chloride that does enter with the oxidant will be partially scrubbed by the electrolyte and partially leave with the oxidant exhaust. Most of the chloride is expected to be scrubbed and be transported to the anode, thereby trapping the chloride in the system, much as sulfur is anticipated to be trapped [33]. The importance of the difference in chloride concentration in the electrolyte as a performance decay mode then increases and the effect of electrolyte loss perhaps reduced. The tracing of the halide flows in system components and the resulting effect on the steady-state halide flows that reach the stack in the fuel and oxidant streams were not considered in the model. The model was developed for comparison with bench-scale, single-cell data. To predict the decay rate due to halides, a system configuration must be selected and the decay phenomena used in the model must be applied to the stack for the resulting rate of halide flows.

Figure 7-2 shows that operating pressure also affects the performance decay due to halides. This pressure effect is caused by the increase in anode polarization as pressure is reduced. Therefore, loss of electrolyte from the anode has a larger effect at a lower pressure.

A final difference between the model predictions and the performance decay that may occur in an actual stack could result due to long term stack 


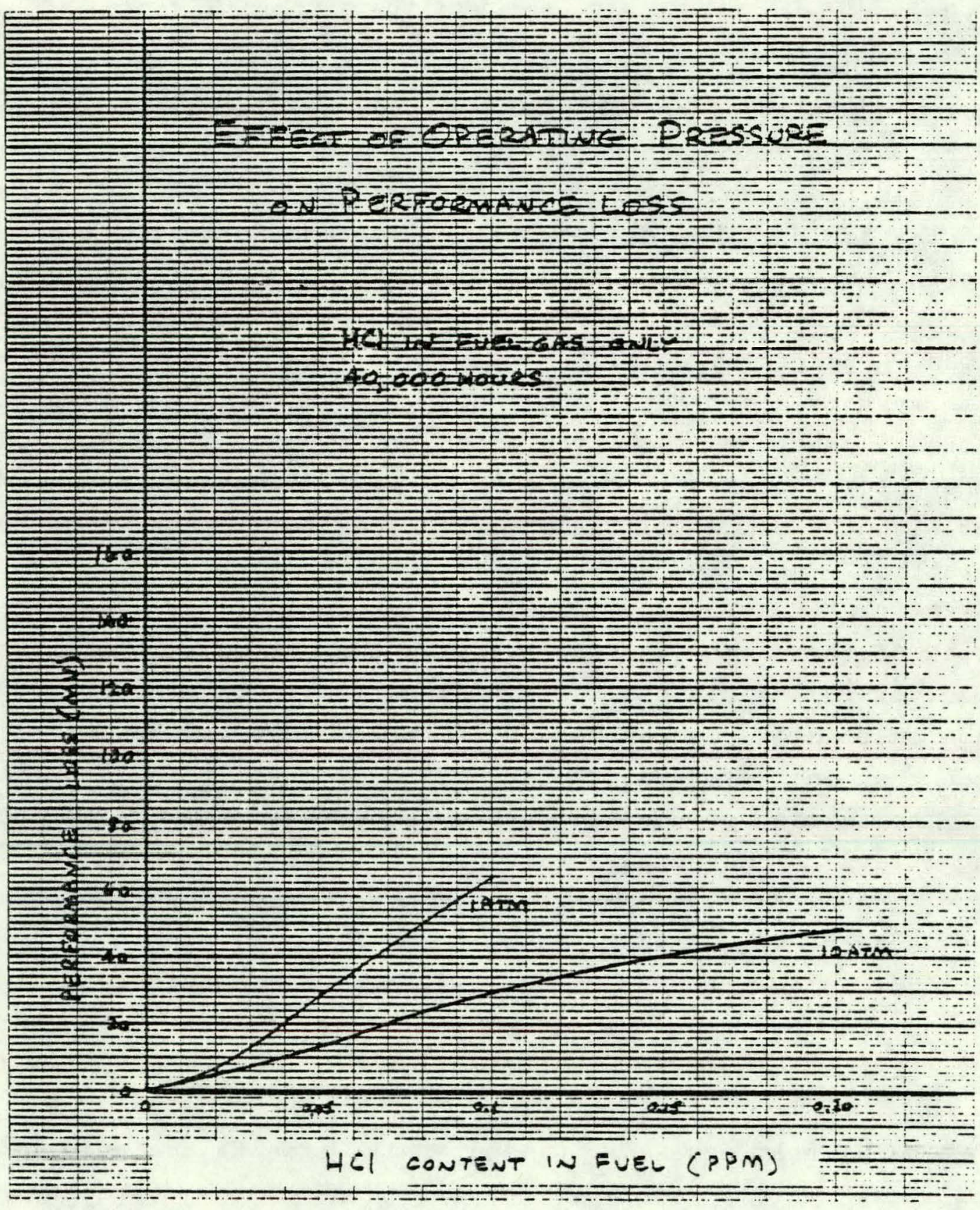

FIGURE 7-2. Effect of Operating Pressure

on Performance Loss 
operation. The model does not include decay due to the increase in corrosion of cell components. The corrosion experiments performed in this program did not show large increases in corrosion rate on the cathode current collector with 1 ppm halide in the oxidant in 1000 hours. However, some changes in the protective oxide scale were found such that temperature cycling over longer periods of operation might result in performance decay due to an increasing contact resistance. The likelihood of this occurring is reduced by the small tolerance level of the cell due to other decay modes.

\section{RECOMMENDATIONS}

Although the experimental data and the model developed in this contract increased the understanding of the effects of halides on molten carbonate fuel cells, the effects halides may have over longer time periods in actual power plants are still uncertain for reasons mentioned above. Long-term endurance tests of single cells using simulated power plant reactants containing low levels of halides are still needed. These tests should include shutdown-restart cycles. Further development of hot-gas cleanup systems should be performed for the removal of halides and other impurities. Molten carbonate power plant system studies should be conducted to evaluate approaches to handle all harmful impurities because the best manner to handle halides may depend on the techniques for handing other impurities. This information should be used to determine the best approach for achieving the desired life of 25,000 to 40,000 hours. 


\section{REFERENCES}

[1] "Development of Molten Carbonate Fuel Cells for Power Generation." Final Report. August 1977 through December 1979. SRD-80-055. Contract AC03-77ET11319. Work performed by General Electric for the Department of Energy, April 1980.

[2] "Development of Molten Carbonate Fuel Cell Power Plant Technology." Quarterly Technical Progress Report 7, April 1, 1981 through June 30, 1981. Contract DE-AC01-79ET15440. Work performed by the Power System Division of the United Technologies Corporation for the Department of Energy, July 1981.

[3] "Development of Molten Carbonate Fuel Cell Power Plant." Quarterly Technical Progress Report. May 1 through July 31, 1982, Contract AC02-80ET17019, Work performed by General Electric for the Department of Energy.

[4] Su-Moon Park and Thomas J. O'Brien, "Effects of Several Trace Contaminants on Fuel Cell Performance." August 1980, Contract DOE/ METC/RI-8U/16.

[5] A.N. Kruglov, V.P. Kochergin, and V.V. Yakovleva, "Thermal Disociation of Sodium and Potassium Carbonates in the Presence of Univalent Metal Chlorides and Fluorides." Russian Journal of Inorganic Chemistry. 13 (7), 1968. pp. 921-923.

[6] D.R. Stull and H. Prophet, "JANAF Thermochemical Tables." 2nd ed. NSRDS-NBS37, U.S. Department of Commerce, June 1971 .

[7] I. Barin and O. Knacke, "Thermochemical Properties of Inorganic substances." Spingerverlag, Dusseldorf, Ccrmany, 1973. 
[8] L.F. Grantham, P.H. Shaw, and R.D. Oldenkamp in Z.H. Foroulis, "High Temperature Metallic Corrosion of Sulfur and its Compounds", The Electrochemical Society, Inc., 1970. p. 253.

[9] R.B. Swaroop, J.W. Sin, and K. Kinoshita, "Corrosion Protection of Molten Carbonate Fuel Cell Gas Seals", J. Electrochem Soc., Vol 125 (11), 1978, P. $1799^{\circ}$

[10] S. Prahacs, J.J.O. Gravel, and W.A. Mueller, "Corrosion Behavior of a 50:49:1 - Cr:Ni:Ti Alloy Exposed to Pyrolysis Conditions of SodiumBase Spent Pulping Liquors - I. Pilot-Scale Experimental Work," Electrochemical Technology, Vol $6(9-10), 1968$, p. 349.

[11] U. Martins and E. Niskanen, "Corrosion Behavior of a 50:49:1 Cr:Ni:Ti Alloy Exposed to Pyrolysis Conditions of Sodium-Base Spent Pulping Liquors - II. Experimental Study of Exposed specimens", Electrochemical Technology, Vol. $6(9-10), 1968$, p. 354.

[12] W.A. Mueller, "Corrosion Behavior of 50:49:1 - Cr:Ni:Ti Alloy Exposed to Pyrolysis Conditions of Sodium-Base Spent Pulping Liquors - III. Mechanism of Attack and Calculation of Corrosion Rates", Electrochemical Technology, Vol. $6(11-12), 1968$, p. 410.

[13] Metals Handbook, 8th Ed., Vol. 2, "Heat Treating, Cleaning and Finishing." American Society for Metals, 1964, p. 51.

[14] Corrosion Handbook, H.H. Uhlig, ed., The Electrochemical Society, John Wiley \& Sons, N.Y., 1984, P. 736.

[15] J.H. Jackson and M.H. LaChance, "Resistance of Cast Fe-Ni-Cr Alloys to Corrosion in Molten Neutral Heat Treating Salts", Am. Soc. Metals 
Trans., Vol. 46, 1954, pp 157-183.

[16] V.P. Kochergin and N.I. Ignat'eva, "Oxidation of Iron in Melts Containing Sodium Halides and Carbonates", Russian Journal of Inorganic Chemistry , Vol. 6, No. 9, pp 1086-1089.

[17] A. Baraka and R.M.S. Baraka, "The Effect of Halides on the Corrosion of Behavior of Nickel in Molten (NA,K) NO${ }_{3}$, J.Applied Electrochem., Vol. 4, 1984, p. 417 .

[18] P. Elliott and G. Marsh, "The Oxidation of Incoloy 800 in Moist A-ir Containing $\mathrm{HCl}(\mathrm{g})$ at $800 \mathrm{Cl}$, Corrosion Science, Vol. 24(5), 1984, p. 397 .

[19] M.K. Hossain and S.R.J. Saunders, "A Microstructural Study of the" Influence of $\mathrm{NaCl}$ Vapor on the Oxidation of a $\mathrm{Ni}-\mathrm{Cr}-\mathrm{Al}$ Alloy at $850 \mathrm{Cl}$, Oxidation of Metals, Vol. 12(1), 1978, p. 1 .

[20] G.J. Janz et. al. "Physical Properties Data Compilations Relevant to Energy Storage." Part 2: Molten Salts: Data on Single and Multi-Component Salt Systems. NSRDS-NBS61. Part II. April 1979. Work performed for Department of Commerce.

[21] Bregoli, L.J., and Kunz, H.R., "The Effect of Thickness on the Performance of Molten Carbonate Fuel Cell Cathodes", J. Electrochem. Soc. 129, pp 2711 to 2715 (1982).

[22] L.J. Van der Pauw. "A Method of Measuring Specific Resistivity and Hall Effect of Discs of Arbitrary Shape." Phillips Research Reports $13,1-9,1958$. 
[23] R.D. Pierce et al. "Advanced Fuel Cell Development." Progress Report for July-September 1980. Argonne National Laboratory. Prepared for U.S. Department of Energy under Contract W-31-109-Eng-38. "Cathode Resistivity Measurement Technique." J.L. Smith and J.R. Stapay. P. ,30.

[24] Kunz, H.R., "Transport of Electrolyte in Mnlten rarbonato Euel Cells", J. Electrochem. Soc., 134, pp 105 (1987).

[25] Merideth, R.E., and Tobias, C.W., Advances in Electrochemistry and Electrochemical Engineering, Vol. 2, pp 15, C.W. Tobias, ed., Interscience Publications, 1966.

[26] "Development of Improved Molten Carbonate Fuel Cell Technology", FCR-5494-F, Final Report on Research Project 1085-4 between United Technologies Corporation and the Electric Power Research Institute (1983).

[27] "Evaluation of Natural Gas Molten Carbonate Power Plants", Final Report on Contract No. 5081-344-0528 between United Technologies and the Gas Research Institute, January 11, 1982 to March 11, 1983.

[28] Rostrup-Nielsen, J.R., Catalytic Steam Reforming, Springer-Verlag, New York, 1984.

[29] Bushnel1, C.L.; Buswell, R.F.; Kunz, H.R.; Meyer, A.P., Reiser, C.A.l Smith, S.W.; and Vogel, W.M.; "Evaluation of NaturalGas Molten Carbonate Power Plants", Final Technical Report on Gas Research Institute Contract No. 5031-344-0528, Prepared by United Technologies Corporation (FCR-5196 (1985) 
[30] Kunz, H.R.; "Transport of Electrolyte in Molten Carbonate Fuel Cells", J. Electrochem Soc. ,Vol. 134, pp 105 to 113 (1987)

[31] Ong, E.T.; Claar, T.D.; and Mavcanowski, L.G.; "Molten Carbonate Electrolyte Vapor Loss Studies", National Fuel Cell Seminar, pp 77 to 80 (1981)

[32] Final Report on Molten Carbonate (Need Russ Kunz Input)

[33] Smith, S.W.; Kunz, H.R.; Vogel, W.M.; and Szymanski, S.J.; "Effects of Sulfur on Molten Carbonate Fuel Cells -- A Survey", The Elecrochem Soc. Proc. Vol. 84-13, pp 246-270 (1984)

[34] M. Temkin. Acta. Physiochem (USSR), 20 (1945) 411

[35] G.J. Janz, "Molten Salts Handbook", Academic Press, Inc. New York, NY 1967, 


\section{APPENDIX A}

\section{ELECTROLYTE THERMODYNAMIC ANALYSIS}

Halides in the form of either HCl or:HF are anticipated to react with the molten carbonate electrolyte by:

$$
\begin{aligned}
& 2 \mathrm{HCl}(\mathrm{g})+\mathrm{M}_{2} \mathrm{CO}_{3}(1) \rightarrow 2 \mathrm{MCl}(1)+\mathrm{H}_{2} \mathrm{O}(\mathrm{g})+\mathrm{CO}_{2}(\mathrm{~g})(\mathrm{A}-1) \\
& 2 \mathrm{HF}(\mathrm{g})+\mathrm{M}_{2} \mathrm{CO}_{3}(1) \rightarrow 2 \mathrm{MF}(1)+\mathrm{H}_{2} \mathrm{O}(\mathrm{g})+\mathrm{CO}_{2}(\mathrm{~g}) \quad(\mathrm{A}-2)
\end{aligned}
$$

where $M$ represents either lithium $(L i)$ or potassium $(K)$.

The ideal activity of an ionized salt $C_{m} A_{n}$ is [34]:

$$
\left(C_{m} A_{n}\right)=\{C\}^{m} \quad\{A\}^{n} \quad(C=\text { Cation, } A=\text { Anion })
$$

$$
\begin{aligned}
& \text { where }\{c\}=\frac{N_{C}}{\sum N_{\text {Aations }}} \quad \text { and }\{A\}=\frac{N_{A}}{\sum N_{\text {ANIONS }}} \\
& N_{i}=\text { moles of ion } i
\end{aligned}
$$

The equilibrium constants for Equations $(A-1)$ and $(A-2)$ are represented by: 


$$
\begin{aligned}
& K_{1}=\frac{\left\{C l^{-}\right\}^{2} P_{\mathrm{H}_{2} \mathrm{O}} P_{\mathrm{CO}_{2}}}{P_{\text {Hel }}^{2}\left\{\mathrm{CO}_{3}^{2-}\right\}} \\
& K_{2}=\frac{\{F \cdot\}^{2} P_{\mathrm{H}_{2} \mathrm{O}} P_{\mathrm{CO}_{2}}}{P_{\mathrm{HF}}^{2}\left\{\mathrm{CO}_{3}^{2-}\right\}}
\end{aligned}
$$

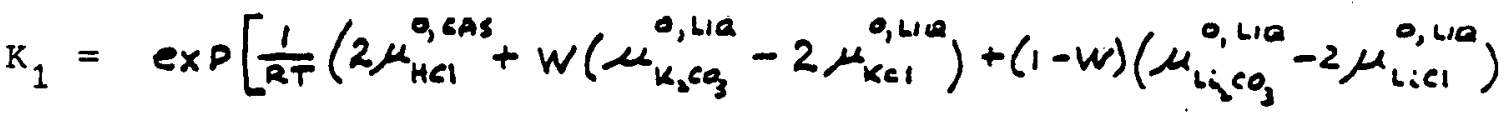

$$
\begin{aligned}
& \left.\left.-\mu_{H_{2} O}^{0, \text { GAS }}-\mu_{\mathrm{CO}_{2}}^{0, \text { GAS }}\right\rangle\right]
\end{aligned}
$$

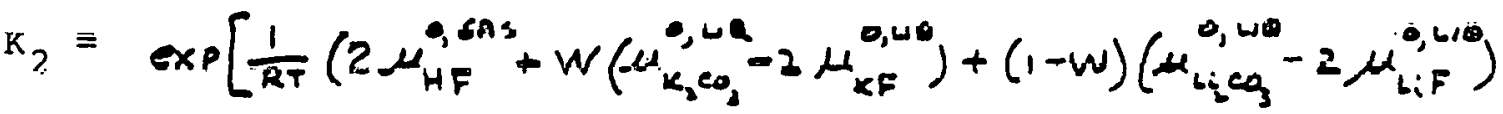

$$
\begin{aligned}
& \left.\left.-\mu_{H_{2} O}^{0, \text { SAl }}-\mu_{C Q_{2}}^{0,6 A s}\right)\right]
\end{aligned}
$$

where

$$
\begin{aligned}
& W=\{K+\} \\
& R=\text { gas constant } \\
& T=\text { temperature } \\
& \mu^{\prime}=\text { standard Gibbs free energy of formation of specie } i
\end{aligned}
$$

$\mathrm{K}_{1}$ and $\mathrm{K}_{2}$ are plotted as a function of temperature in Figures $\mathrm{A}=1$ and $A-2$, respectively.

A-2 


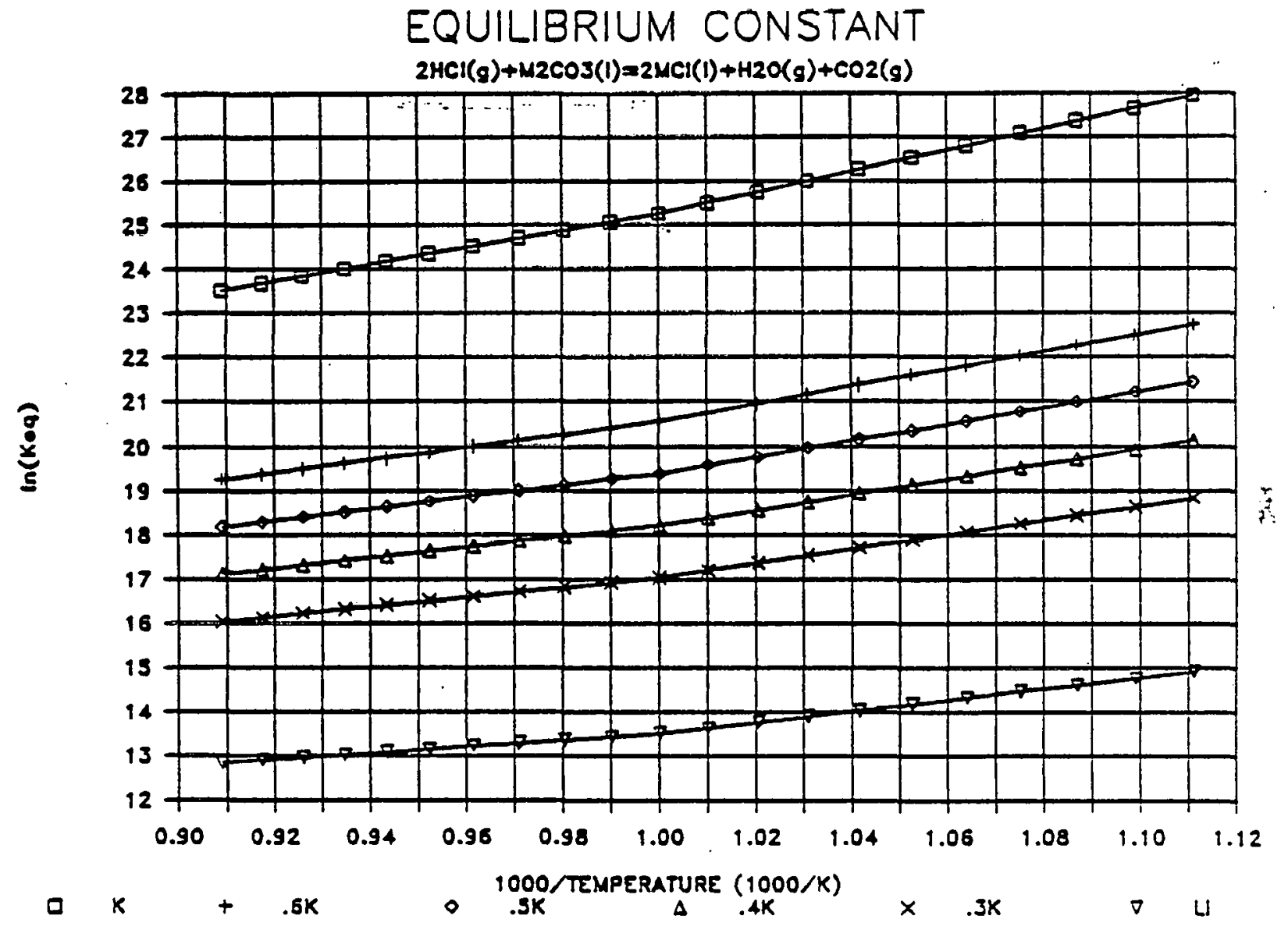

FIGURE A-1. Equilibrium Constant for Reaction A-1

$$
A-3
$$




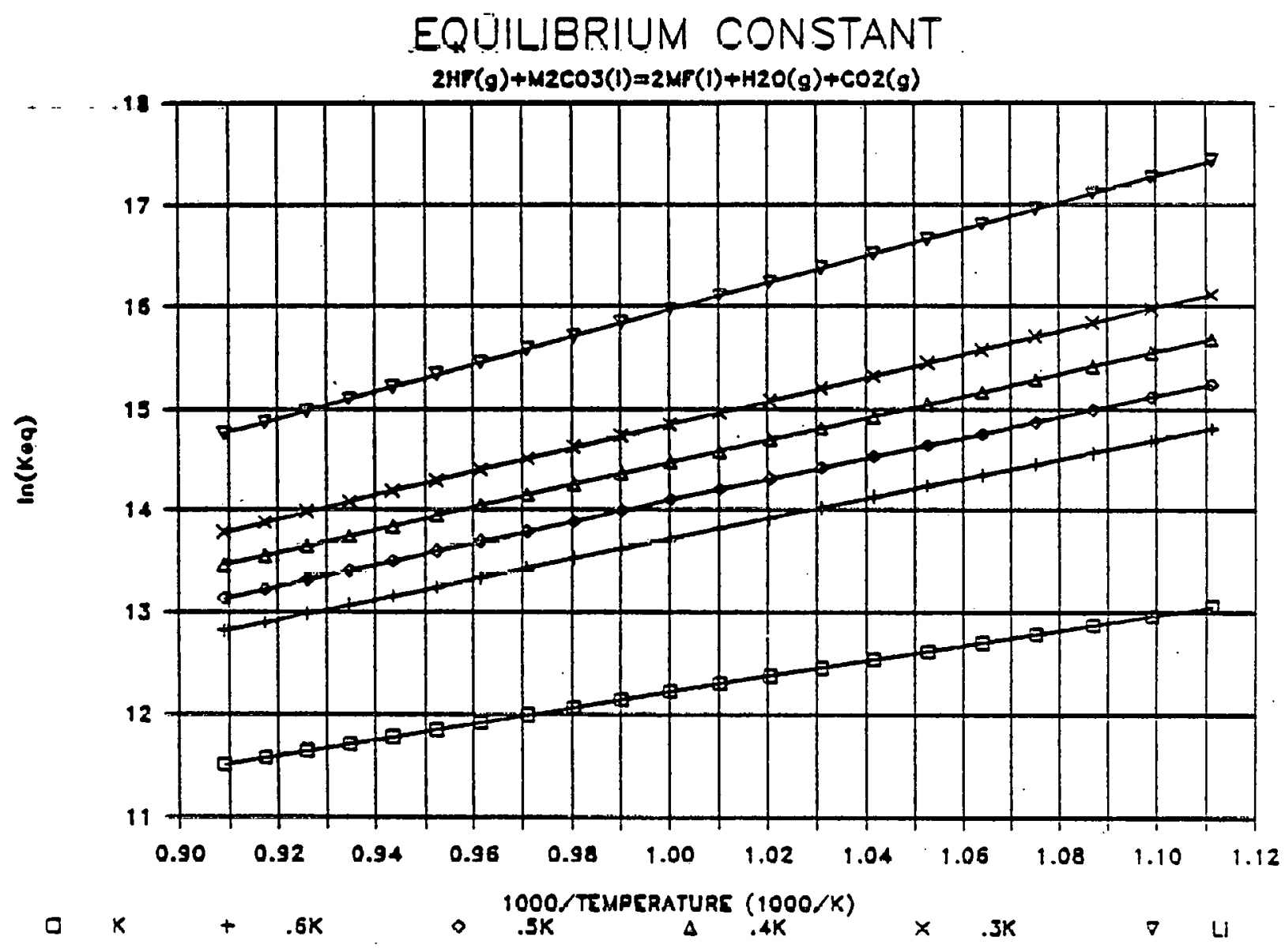

FIGURE A-2. Equilibrium Constant for Reaction A-2

$$
\text { A- } 4
$$


The vaporization of the alkali-metal halide is also important:

$$
\begin{aligned}
& \mathrm{KCl}(1) \rightrightarrows \operatorname{KCI}(g) \quad(A-3) \\
& \operatorname{LiCl}(1) \rightleftarrows \operatorname{LiCl}(g) \quad(A-4) \\
& \mathrm{KF}(1) \rightleftarrows \mathrm{KF}(\mathrm{g}) \quad(\mathrm{A}-5) \\
& \operatorname{LiF}(1) \rightleftarrows \operatorname{LiF}(g)
\end{aligned}
$$

Equilibrium constants for Equations $(A-3)-(A-6)$ can also be calculated from JANAF data [6]:

$$
\begin{aligned}
& K_{3}=\frac{P_{K C 1}}{\{K+\}\{C 1-\}}=\exp \left[\frac{1}{R T}\left(\mu_{K C 1}^{0, w e}-\mu_{K C 1}^{0, C A S}\right)\right] \\
& K_{4}=\frac{P_{L C l}}{\left\{L_{i}^{+}\right\}\{C l\}}=\exp \left[\frac{1}{R_{T}}\left(\mu_{L i C l}^{0, w Q}-\mu_{\text {liCl }}^{\text {qCAS }}\right)\right] \\
& K_{5}=\frac{P_{K F}}{\{k+\}\{F-\}}=\exp \left[\frac{1}{R T}\left(\mu_{K F}^{0, \omega Q}-\mu_{K F}^{0, G A S}\right)\right] \\
& K_{6}=\frac{P_{L i F}}{\left\{L_{i}{ }^{+}\right\}\{F-\}}=\exp \left[\frac{1}{R T}\left(\mu_{\text {LiF }}^{0,4 \Omega}-\mu_{L i F}^{0,6 A S}\right)\right]
\end{aligned}
$$

$\mathrm{K}_{3}, \mathrm{~K}_{4}, \mathrm{~K}_{5}$ and $\mathrm{K}_{6}$ are plotted as a function of temperature in Figures $A-3-A-6$, respectively: Each of the gaseous species in Equations $(A-3)-(A-6)$ polymerize. The dimerisation equations are:

$$
\begin{aligned}
& 2 \mathrm{KCl}(\mathrm{g}) \rightleftarrows \mathrm{K}_{2} \mathrm{Cl}_{2}(\mathrm{~g}) \\
& 2 \mathrm{LiCl}(\mathrm{g}) \cdot \vec{\leftarrow} \mathrm{Li}_{2} \mathrm{Cl}_{2}(\mathrm{~g})
\end{aligned}
$$




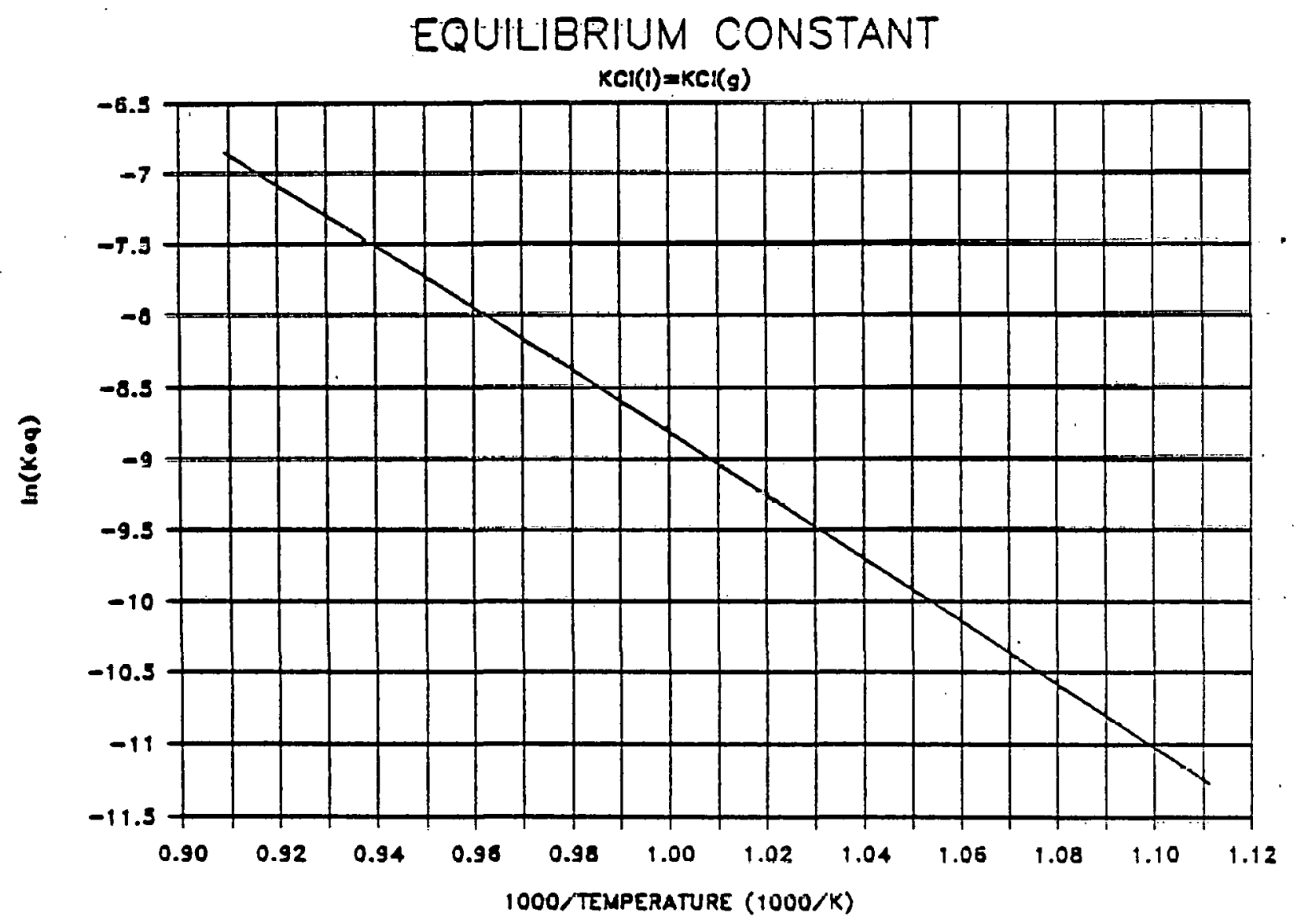

FIGURE $A-3$. Equilibrium constant for Reaction $A-3$ 


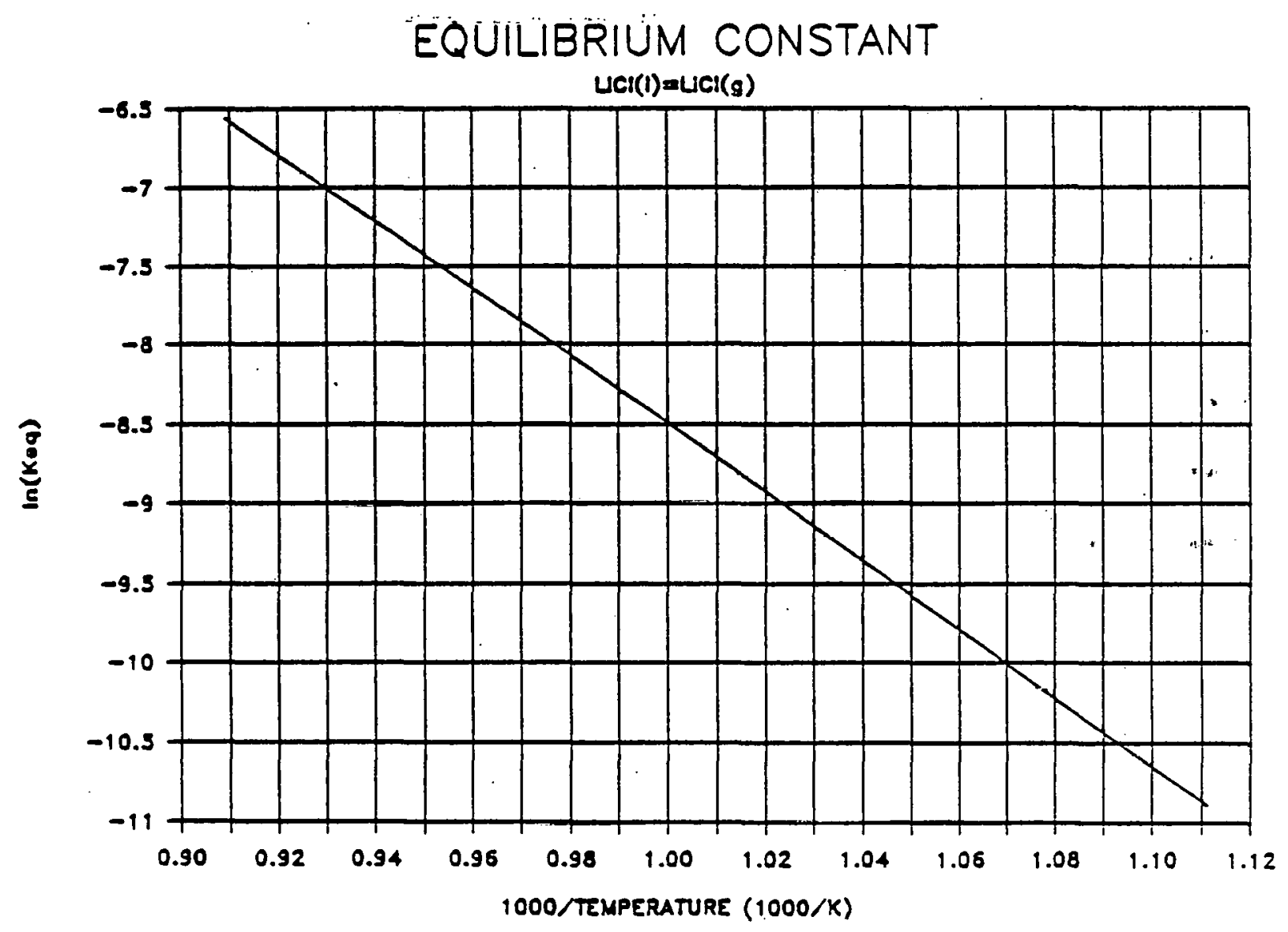

FIGURE A-4, Equilibrium Constant for Reaction A-4 


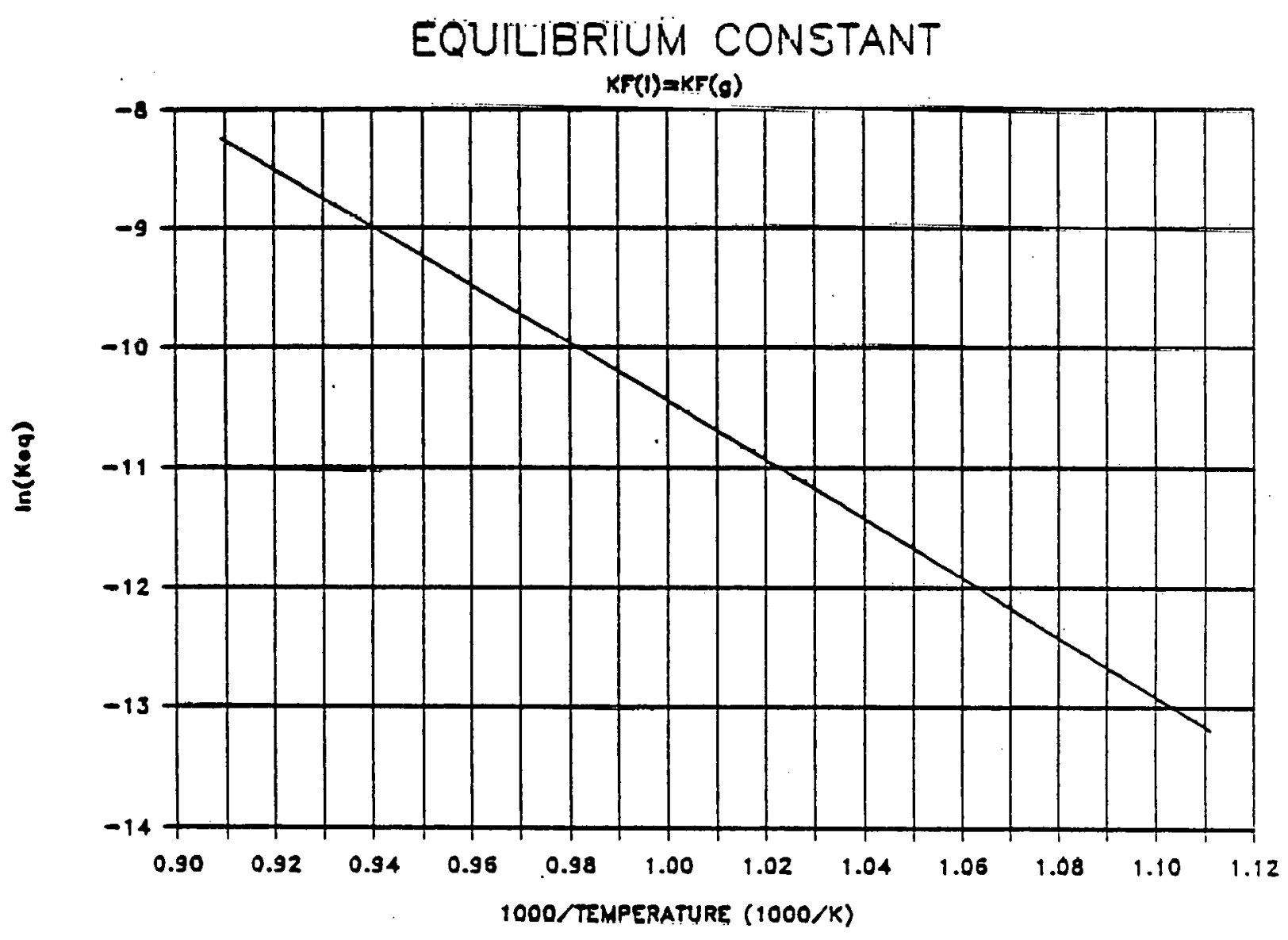

FIGURE A-5. Equilibrium Constant for Reaction A-5

$$
A-8
$$




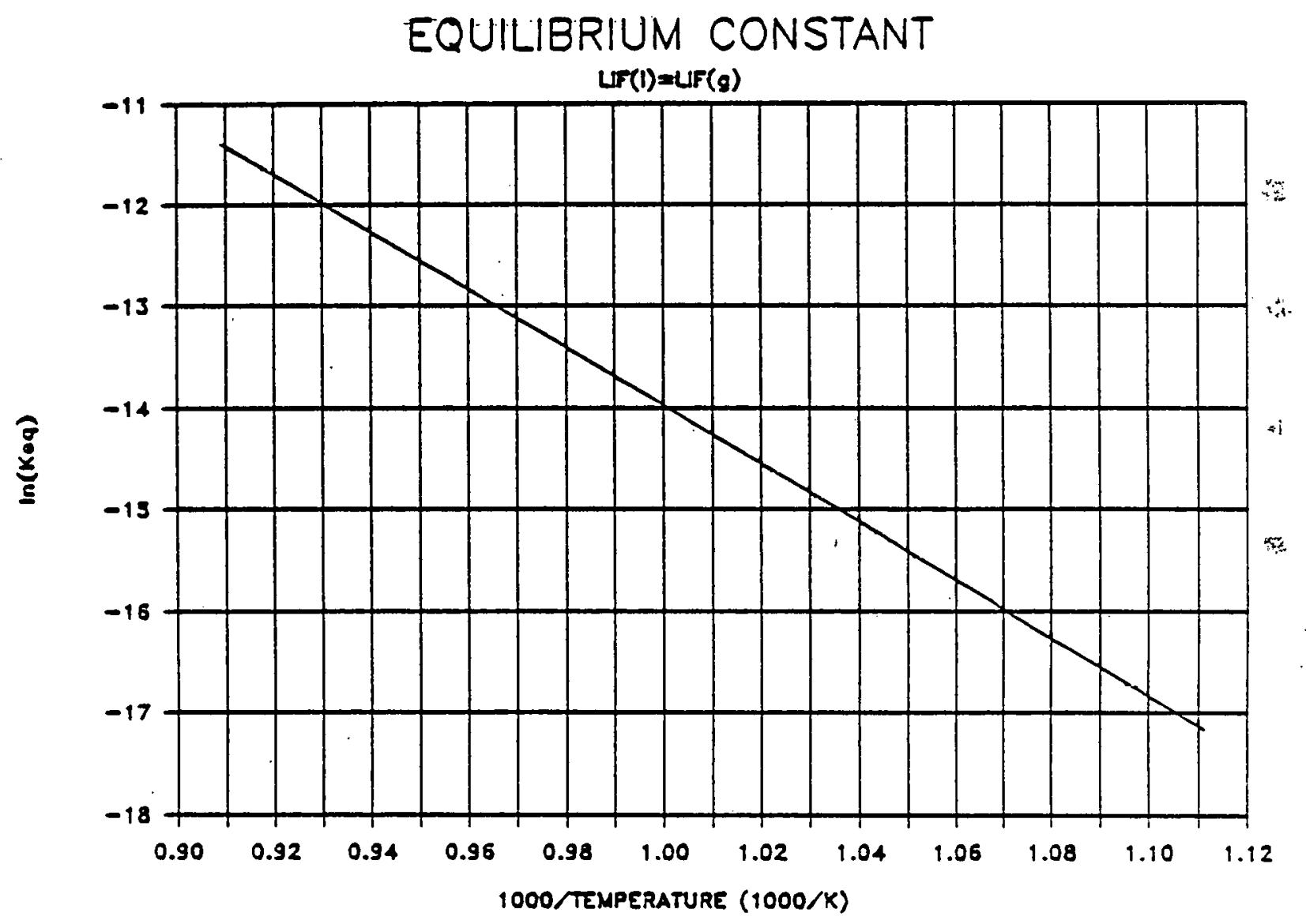

FIGURE A-6. Equilibrium Constant for Reaction A-6

$$
\text { A }-9
$$




$$
\begin{aligned}
& 2 \mathrm{KF}(\mathrm{g}) \rightleftarrows \mathrm{K}_{2} \mathrm{~F}_{2}(\mathrm{~g}) \\
& 2 \mathrm{LiF}(\mathrm{g}) \rightleftarrows \mathrm{Li}_{2} \mathrm{~F}_{2}(\mathrm{~g})
\end{aligned}
$$

$(A-9)$

$(A-10)$

Equilibrium constants for Equations $(A-7)$ - $(A-10)$ are calculated from JANAF data [6]:

$$
\begin{aligned}
& K_{7}=\frac{P_{K_{2} \in I_{2}}}{P_{K C 1}^{2}}=\exp \left[\frac{1}{R_{T}}\left(2 \mu_{K C 1}^{0, O A s}-\mu_{K_{L} C I_{2}}^{0, A_{A}}\right)\right] \\
& K_{g}=\frac{P_{L_{i} C_{2}}}{P_{L i C l}^{2}}=\operatorname{exP}\left[\frac{1}{R_{T}}\left(2, \mu_{L i C l}^{0, O A S}-\mu_{L L_{2} O_{2}}^{0, O A S}\right)\right] \\
& K_{a}=\frac{P_{K} F_{2}}{P_{K F}^{2}}=\operatorname{exP}\left[\frac{1}{R T}\left(2 \mu_{K F}^{0,6 A S}-\mu_{K_{2} F_{2}}^{0, \text { SAl }}\right)\right] \\
& K_{10}=\frac{P_{L L_{2} F_{2}}}{P_{L i F}^{2}}=\operatorname{exP}\left[\frac{1}{R T}\left(2 \mu_{L i F}^{0,6 A S}-\mu_{L i_{2} F_{2}}^{0, \text { mAS }}\right)\right]
\end{aligned}
$$

$\mathrm{K}_{7}, \mathrm{~K}_{8}, \mathrm{~K}_{9}$, and $\mathrm{K}_{10}$ are plotted as a function of temperature in Figures A-7 - A10, respectively. Free energy data for potassium chloride and potassium fluoride trimers were not available, but data were used to calculate the lithium chloride and lithium fluoride trimerization equilibrim constants [6]. The equations for the trimerization of the monomer in the molten state are:

$$
\begin{aligned}
& 3 \mathrm{LiCl}(1) \rightleftarrows \mathrm{LI}_{3} \mathrm{Cl}_{3}(g) \\
& 3 \mathrm{LiF}(1) \rightleftarrows \mathrm{Li}_{3} \mathrm{~F}_{3}(g)
\end{aligned}
$$

$(A-11)$

$(A-12)$

Equilibrium constants for Equations $(A-11)$ and $(A-12)$ are calculated from JANAF data [6]:

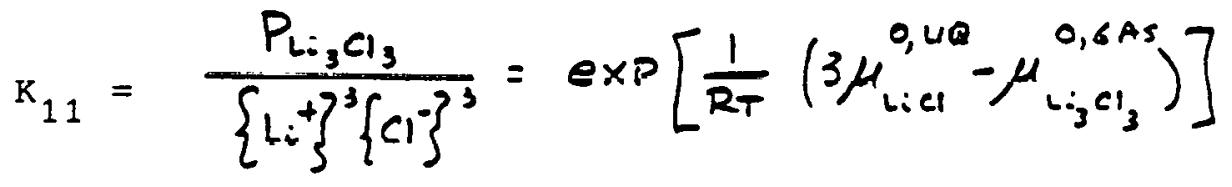

$$
\begin{aligned}
& k_{12}=\frac{P_{L i,} F_{3}}{\left\{L_{i}\right\}^{3}\{F\}^{3}}=\exp \left[\frac{1}{R T}\left\{3 \mu_{L i F}^{0, w Q}-\mu_{L, F_{3}}^{0, G A S}\right)\right] \\
& \text { A }-10
\end{aligned}
$$




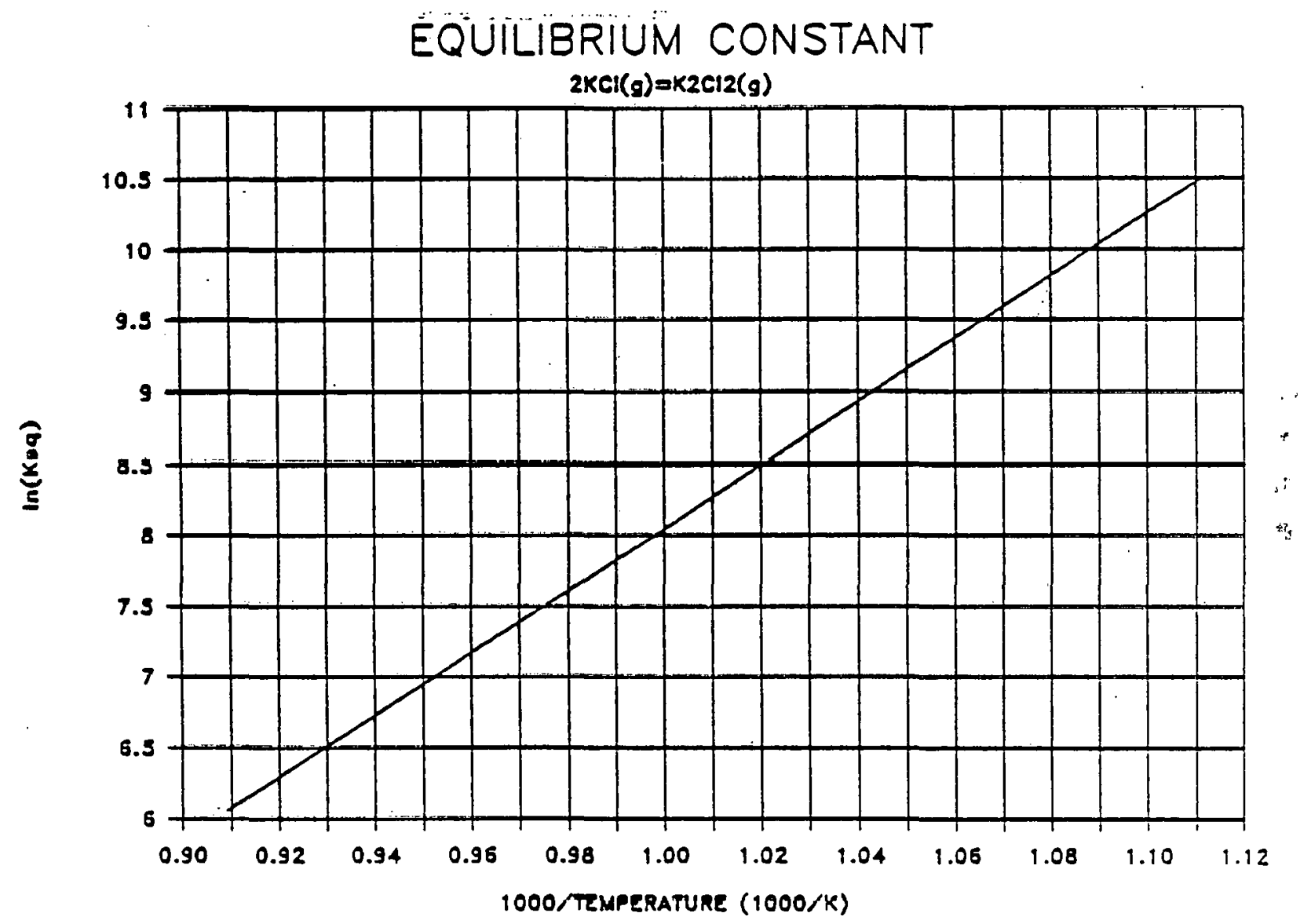

FIGURE A-7. Equilibrium Constant for Reaction A-7 


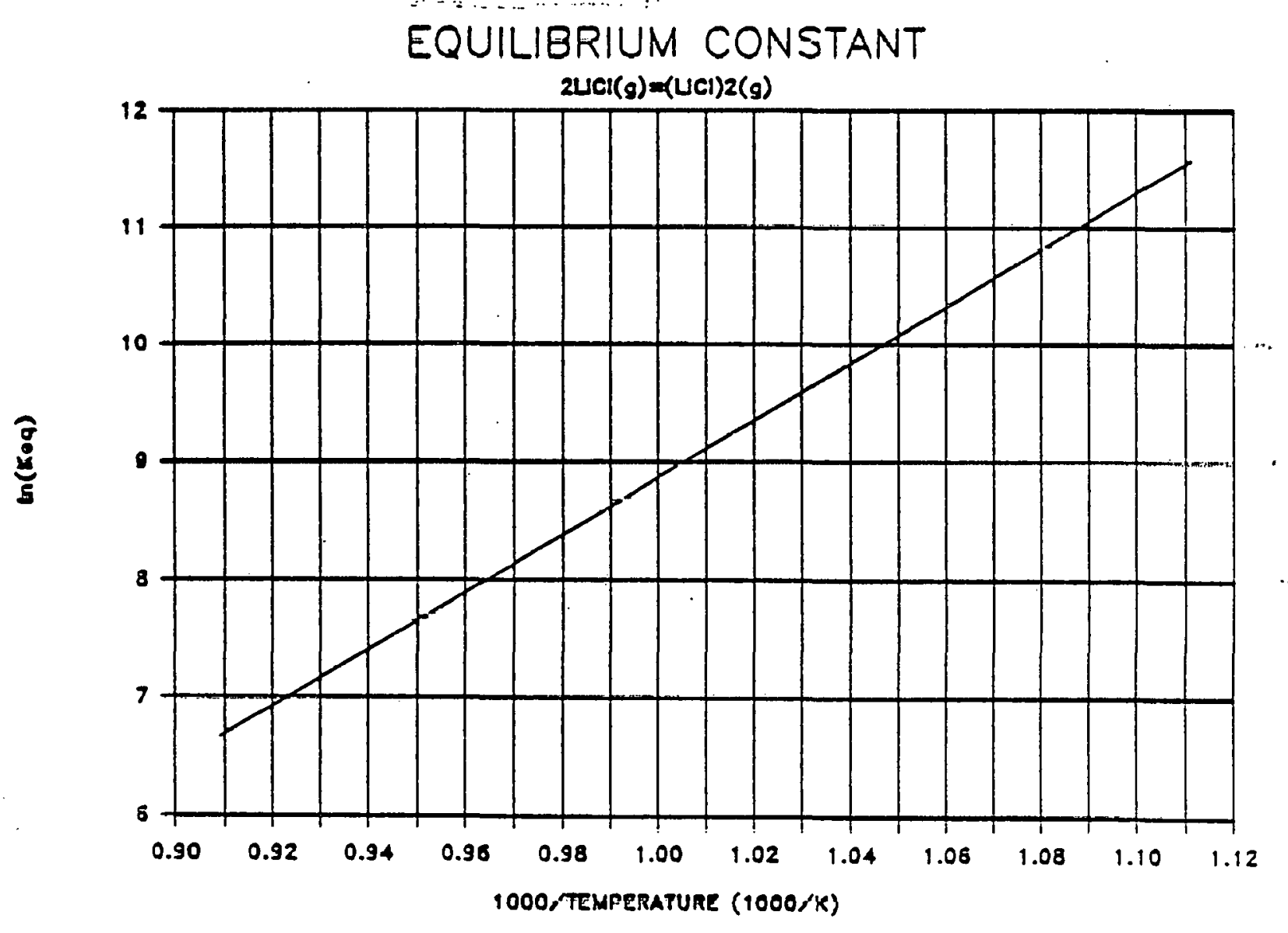

FIGURE A-8. Equilibrium Constant for Reaction $A-8$

$$
\text { A }-12
$$



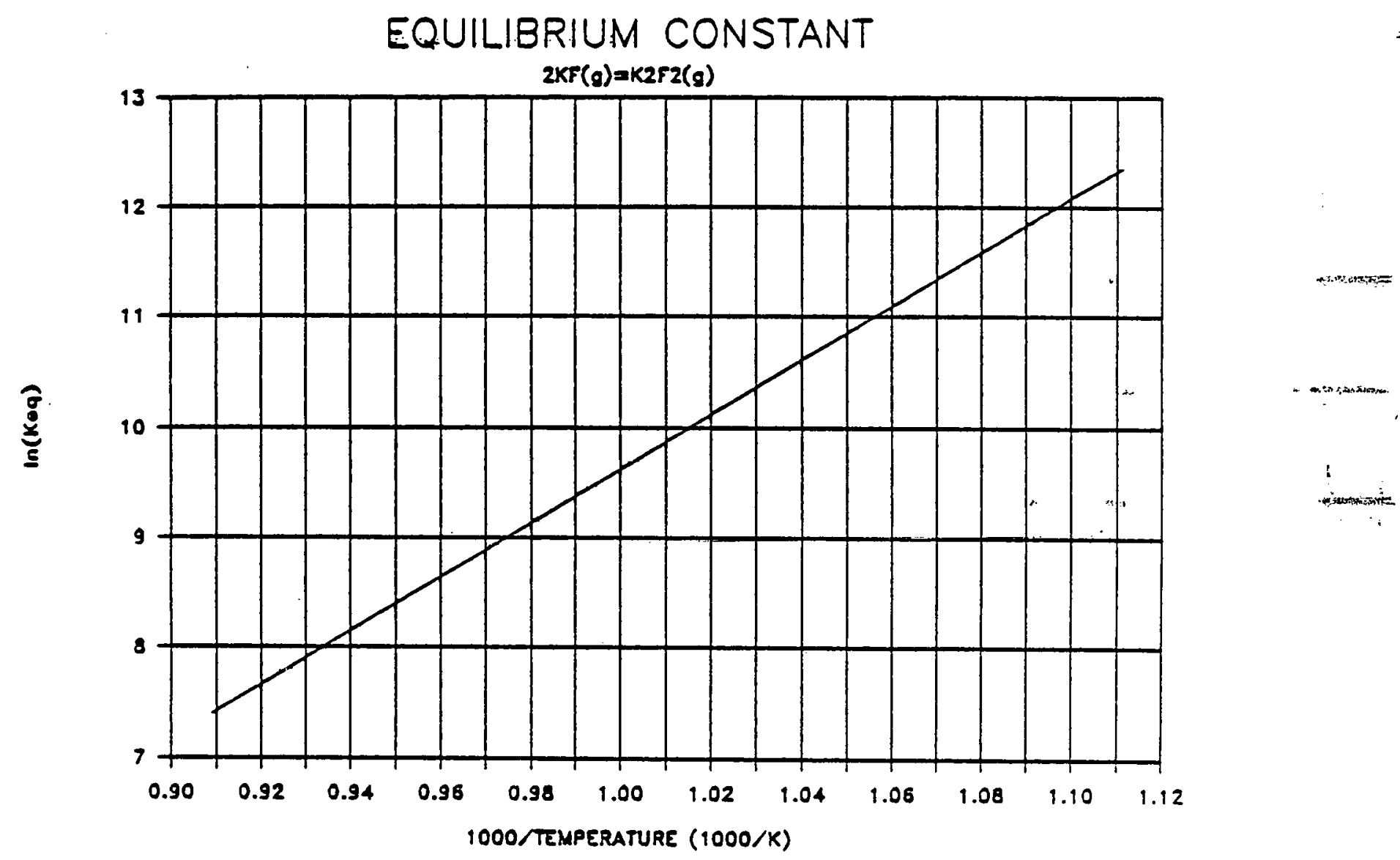

FIGURE A-9. Equilibrium Constant for Reaction A-9

$$
A-13
$$


EQUILIBRIUM CONSTANT

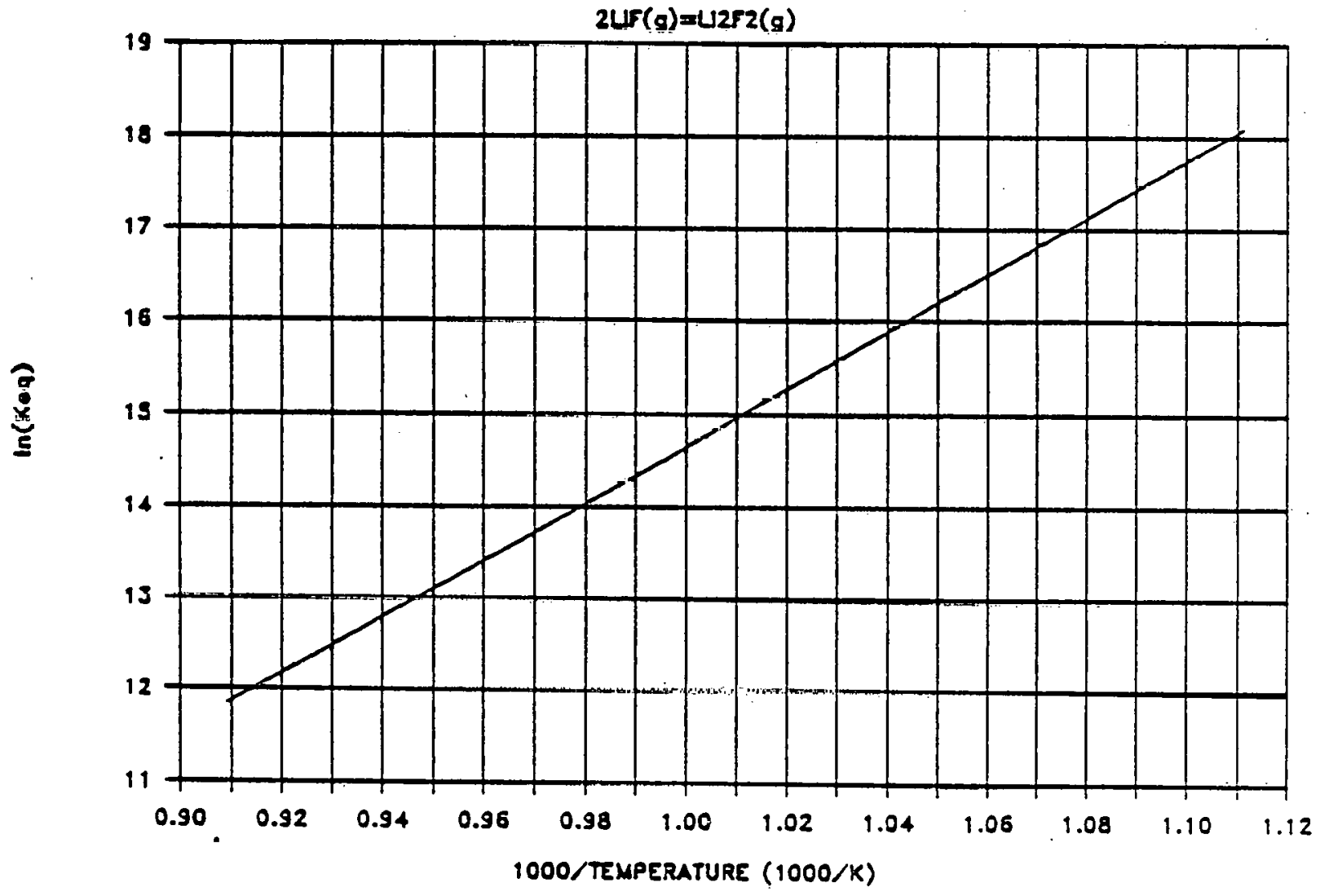

FIGURE A-10. Equilibrium Constant for Reaction A-10

$$
A-14
$$


$K_{11}$ and $K_{12}$ are plotted as a function of temperature in Figures $A-11$ and $A-12$, respectively.

Equilibrium Constant vs Temperature 3uct(1) $=43 \mathrm{Cl3}(\mathrm{g})$

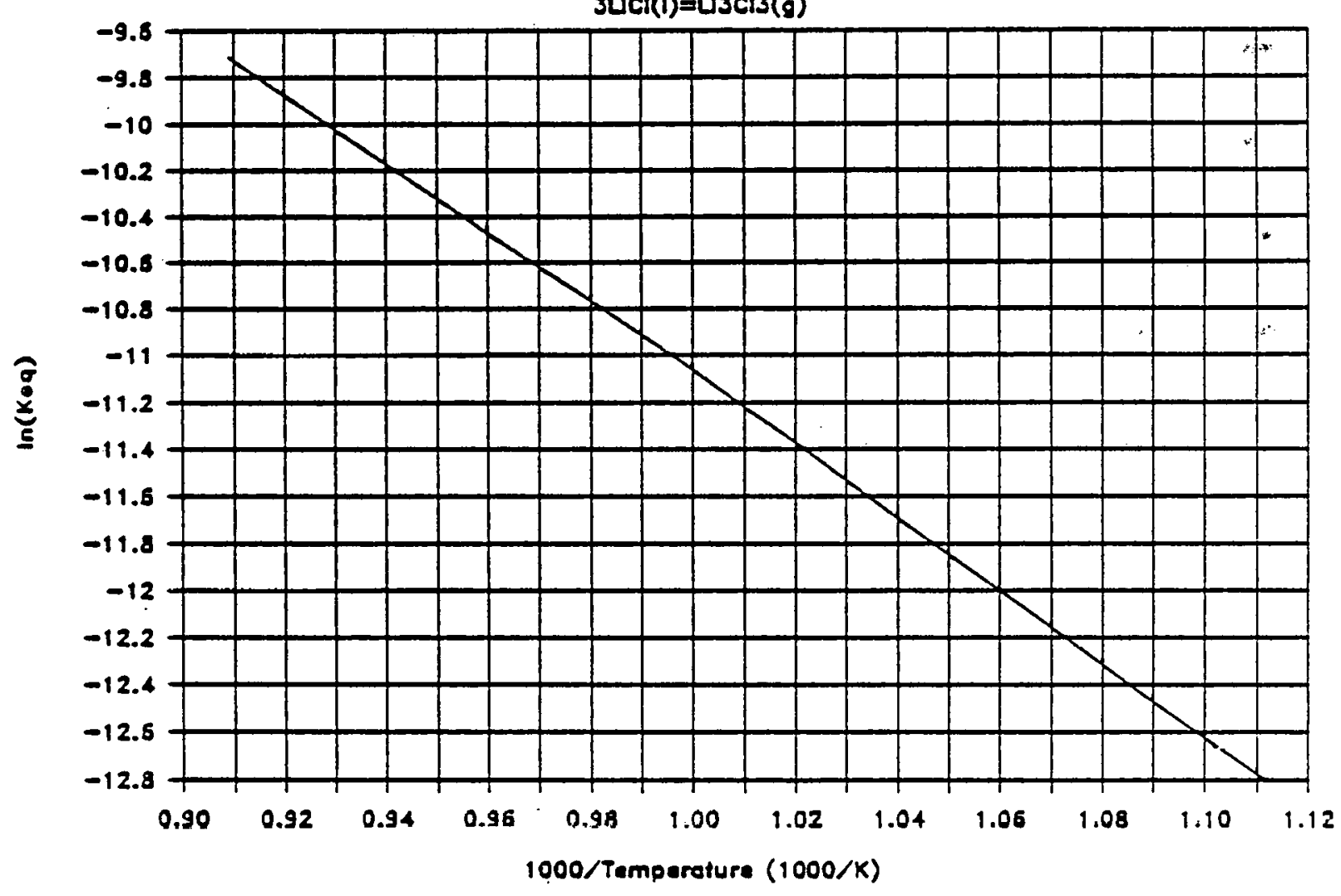

FIGURE A-11. Equilibrium Constant vs. Temperature $3 \operatorname{LiCl}(1)=\operatorname{Li} 3 C_{13}(\mathrm{~g})$ 


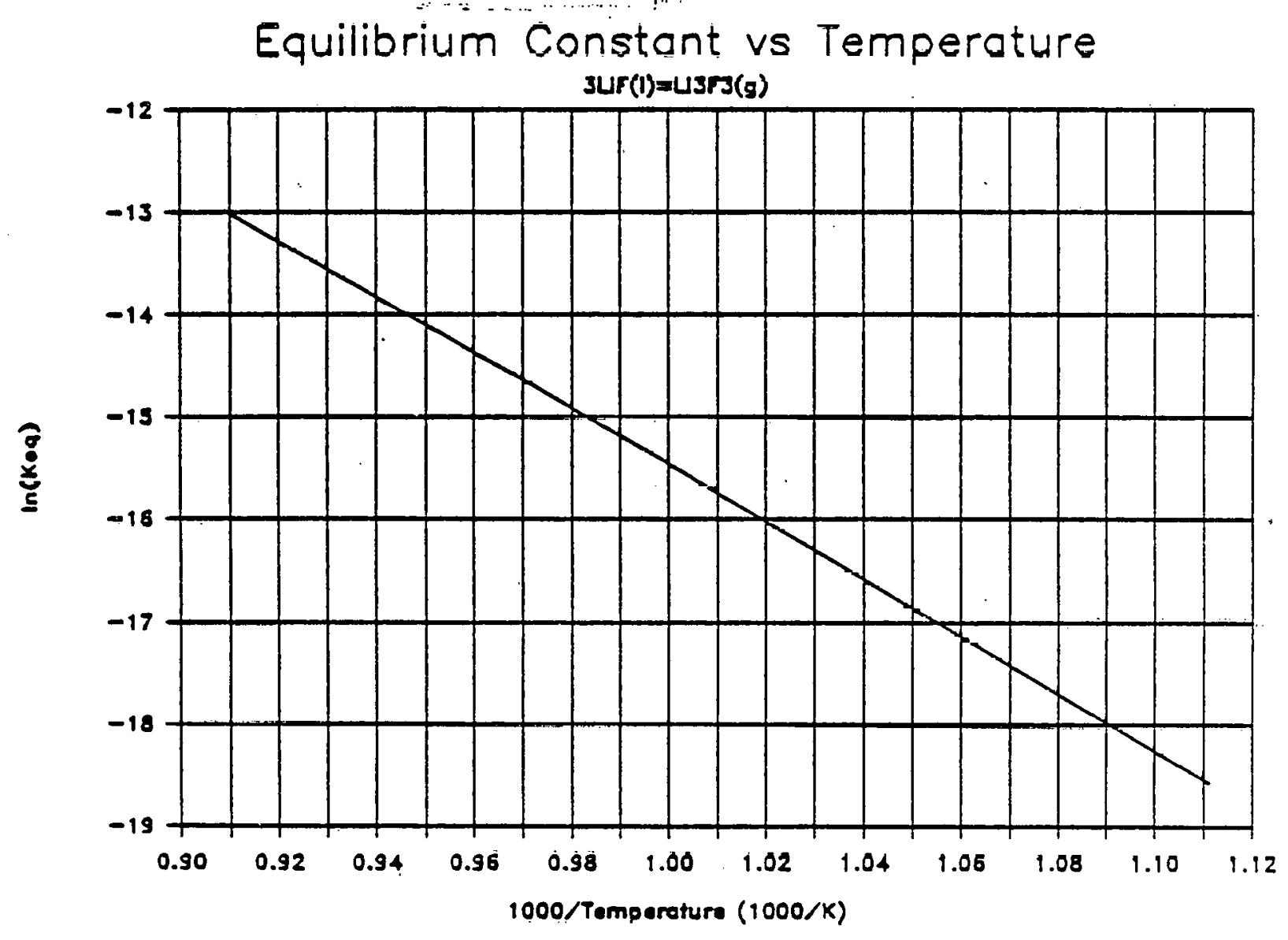

FIGURE A-12. Equilibrium Constant vs. Temperature $3 \operatorname{LiF}(1)=\operatorname{Li} 3 F 3(g)$

A-16 


\author{
APPENDIX B \\ TASK 2 \\ TEST PLAN \\ DESCRIPTION OF EXPERIMENTS \\ TASK 3 \\ OUT-OF-CELL INVESTIGATION
}

\begin{abstract}
Three types of out-of-cell experiments will be performed: corrosion tests, anode-side half-cell tests, and cathode-side half-cell tests.

\section{Corrosion Tests}

Objective - To determine influence of chlorides and fluorides on the corrosion of cathode-side alloys in molten carbonate electrolyte."

Success Criteria - The thickness and stability of protective oxide layers on the alloys is determined as a function of time in halide-containing carbonate electrolyte.

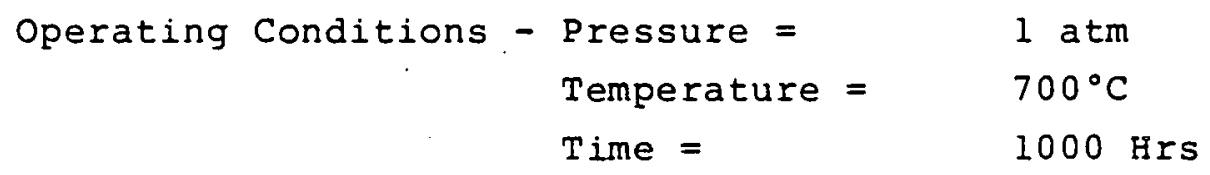

Number of Tests - One electrolytc composition $\left(72 \mathrm{ill}\right.$ 告 $\mathrm{Li}_{2} \mathrm{CO}_{3}, 28 \mathrm{~m} \%$ $\mathrm{K}_{2} \mathrm{CO}_{3}$ converted to contain 3.1 anion percent halide) for both chloride and fluoride with three materials (AISI 316 stainless steel, AISI 310 stainless steel, and Incoloy 825) making six tests.

Oxidant Composition $-9.5 \mathrm{~m} \% \mathrm{O}_{2}, 7.2 \mathrm{~m} \div \mathrm{CO}_{2} \cdot 64.6 \mathrm{~m} \% \mathrm{~N}_{2}$ ' $18.7 \mathrm{~m} \% \mathrm{H}_{2} \mathrm{O}$ 
Electrolyte Halide Concentration - 1 ppm gas-phase equivalent for chloride ( 3.1 anion percent halide).

Parameters to be measured - Inttial thickness

Final thickness

Inttlal welght

Final weight

Metallographic analysis of oxide layer

$x$-ray diffraction analysis of oxide layer

Chemical analysis of oxide layer

Material of Construction -

AISI 316 stainless steel

AISI 310 stainless steel

Inconel 825

Configuration - Rectangular Coupon - 1-inch by 0.5 -inch by 0.060 -inch

\section{Anode-Eide Hait-Coll Tegts}

Objective - To determine the short-term effects of chlorides and fluorides on the performance of anode-side components.

Success Criteria - Short-term steady-state performance data are obtained as a function of chloride and fluoride content in the carbonate electrolyte.

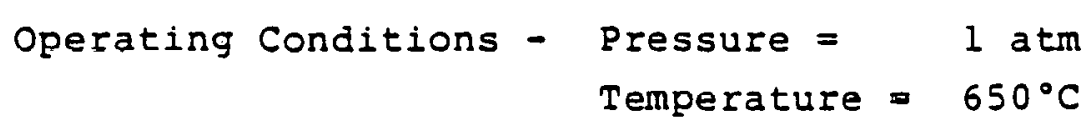

Number of Tests - Three electrolyte compositions $172 \mathrm{~m} 8 \mathrm{Li}_{2} \mathrm{CO}_{3}, 28 \mathrm{~m} \&$ $\mathrm{K}_{2} \mathrm{CO}_{3}$ containing no halide, 23 anion percent chlorides and 23 anion 
percent fluoride) resulting in three tests.

Fuel Composition $-29.4 \mathrm{~m}_{2} \mathrm{H}_{2}, 5.5 \mathrm{~m} \% \mathrm{CO}, 17.5 \mathrm{~m} \% \mathrm{CO}_{2}, 47.6 \mathrm{~m} \% \mathrm{H}_{2} \mathrm{O}$ Gas Phase Halide Concentration - 10 ppm for chloride, 0.3 ppm for fluoride.

Parameters to be Measured - Half-cell voltage, current, temperature, halide content in fuel gas, pretest component thicknesses, post-test analyses (see Task 5).

Materials of Construction - Anode - nickel containing $2 \%$ chromium Bubble barrier - nickel containing $2 \%$ chromium Matrix - lithium aluminate Anode current collector plate - nickel

Electrolyte - $72 \mathrm{~m} \% \mathrm{Li}_{2} \mathrm{CO}_{3}, 28 \mathrm{~m} \% \mathrm{~K}_{2} \mathrm{CO}_{3}$ partially converted to contain 23 anion percent halide. This halide concentration is calculated to be in equilibrium with $10 \mathrm{ppm}$ in the gas phase for chloride and $0.3 \mathrm{ppm}$ in the gas phase for fluoride.

Configuration of Cell - Anode - 0.060 inches thick - ribbed
Components
Bubble Barrier - 0.004 inches thick See Figure B-1 for rig configuration. 


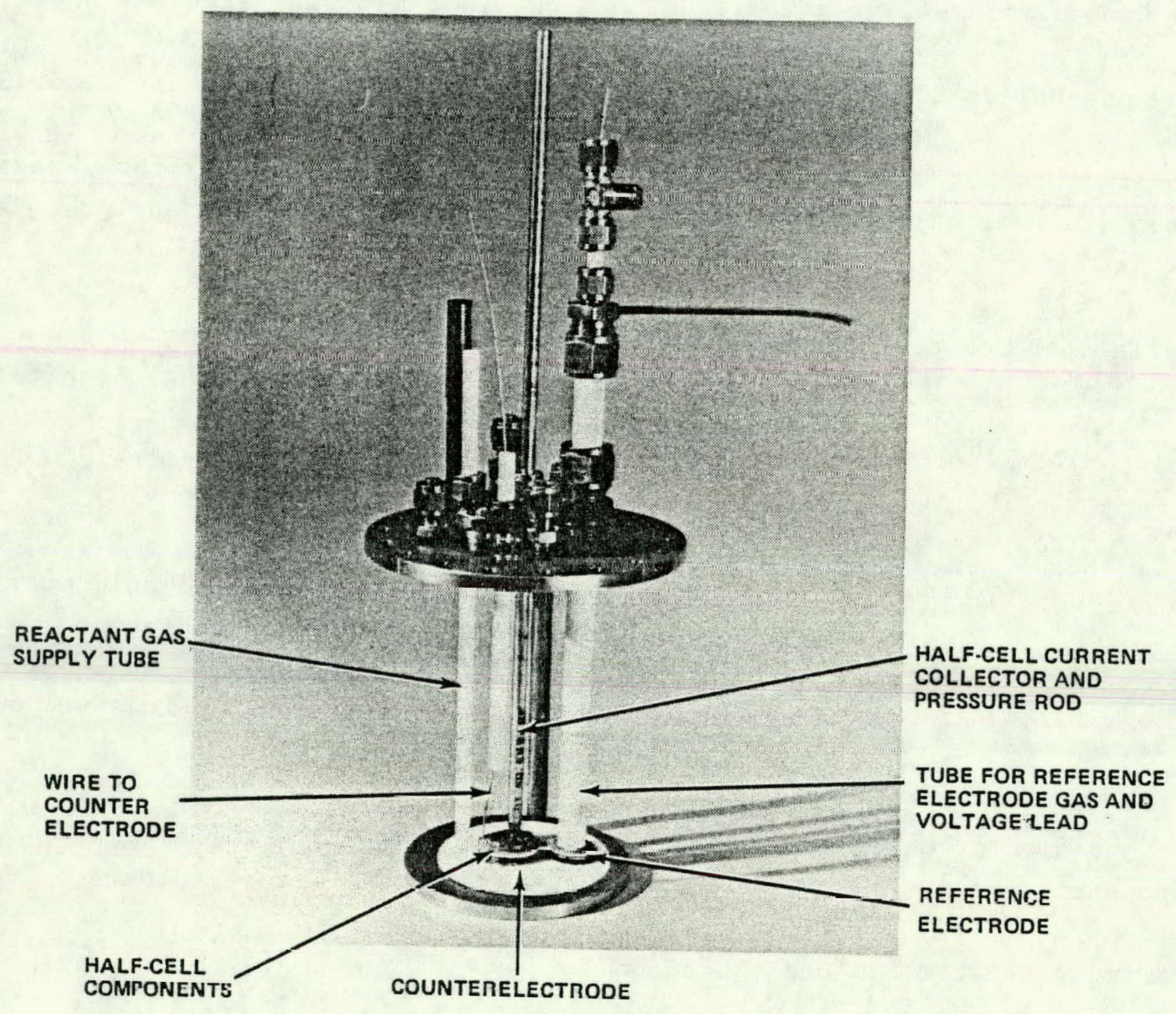

FIGURE B-1 Aalf-Cel1 Apparatus 


\section{Cathode-Side Half-Cell Tests}

Objective - To determine the short-term effects of chlorides and fluorides on the performance of cathode-side components.

Success Criteria - Short-term steady-state performance data are obtained as a function of chloride and fluoride content in the carbonate electrolyte.

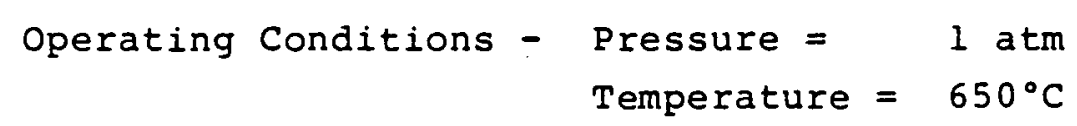

Number of Tests - Two electrolyte compositions $172 \mathrm{~m} \% \mathrm{Li}_{2} \mathrm{CO}_{3}, 28 \mathrm{~m} \%$ $\mathrm{K}_{2} \mathrm{CO}_{3}$ converted to contain 3.1 and 23 anion percent halidel for chloride, one electrolyte composition (23 anion percent halide) for fluoride, and halide-free electrolyte resulting in four tests.

Oxidant Composition $-9.5 \% \mathrm{O}_{2}, 7.2 \mathrm{~m} 8 \mathrm{CO}_{2}, 64.6 \mathrm{~m} \% \mathrm{~N}_{2}, 18.7 \mathrm{~m} \%$ $\mathrm{H}_{2} \mathrm{O}$

Gas-Phase Halide Concentration - 1 ppm and 10 ppm for chloride

- $0.3 \mathrm{ppm}$ for fluoride

Parameters to be Measured - Half-Cell Voltage, current, temperature, halide content in the oxidant gas, pretest component thicknesses, posttest analyses (see Task 5).

Materials of Construction - Cathode - in-situ lithiated nickel oxide

Cathode current collector - AISI 310 stainless steel 
Matrix - lithium aluminate

Electrolyte - $72 \mathrm{~m}$ \% $\mathrm{Li}_{2} \mathrm{CO}_{3}, 28 \mathrm{~m} \& \mathrm{~K}_{2} \mathrm{CO}_{3}$ partially converted to contain 3.1 or 23 anion percent halide. These halide concentrations are the steady state values when l ppm or 10 ppm ". shlocide, respertively, are present in the gas phase. For fluoride, 23 anion percent in the electrolyte corresponds to $0.3 \mathrm{ppm}$ in the gas phase.

Confiquration of Cell Components - Cathode - 0.040 inches thick

- Current Collector - 0.058 inches thick shielded slot 


\section{TASK 5}

\section{POST-TEST ANALYSIS}

The post-test analyses depend on the particular experiment.

\section{$\underline{\text { Task } 3}$}

\section{Corrosion Tests}

Post-test samples will be weighed and their thicknesses determined. They will be sectioned and the thicknesses, conditions and compositions of the corrosion layers determined.

\section{Anode-Side Half-Cell Tests}

The components will be visually inspected and component thicknesses measured.

\section{Cathode-Side Half-Cell Tests}

The components will be visually inspected and component thicknesses measured. . 
